$m-5242$

DOE/OR/01-1501\&D1

ORNL/M- - 5242

\title{
Removal Site Evaluation Report for the Isotope Facilities at Oak Ridge National Laboratory, Oak Riḍge, Tennessee
}

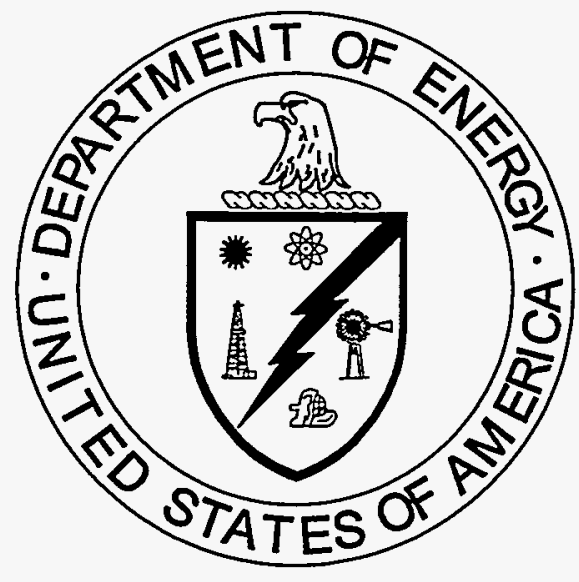

RECEVED

JAN 29 亿997

OSTI

MASTER

DISTEIDITIOH OF THE DOCIRAENT IS UNLIMITED r

This document has been approved by the ORNL Technical Information Office for release to the public. Date: $7 / 29 / 94$ 


\section{Advanced Sciences, Inc.}

contributed to the preparation of this document and should not be considered an eligible contractor for its review.

This report has been reproduced directly from the best available copy.

Available to DOE and DOE contractors from the Office of Scientific and Technical Information, P.O. Box 62, Oak Ridge, TN 37831; prices available from 423-576-8401 (fax 423-576-2865).

Available to the public from the National Technical Information Service, U.S. Department of Commerce, 5285 Port Royal Rd., Springfield, VA 22161. 


\section{DISCLAIMER}

Portions of this document may be illegible in electronic image products. Images are produced from the best available original document. 


\section{PREFACE}

This document, Removal Site Evaluation Report for the Isotope Facilities at Oak Ridge National Laboratory, Oak Ridge, Tennessee (DOE/OR/01-1501\&D1) was prepared in accordance with requirements under the Comprehensive Environmental Response, Compensation, and Liability Act of 1980. This work was performed under Work Breakdown Structure 1.6.6.2.10.2, "Oak Ridge National Laboratory Isotopes Facilities," and Activity Data Sheet Number 6504IS, "Oak Ridge National Laboratory Isotopes Facilities Shutdown Program." Publication of this document provides the Environmental Restoration Program with information necessary to evaluate whether hazardous and/or radiological contaminants in and around the Isotopes Facilities pose a substantial risk to human health or the environment and if remedial site evaluations or removal actions are required. 


\section{CONTENTS}

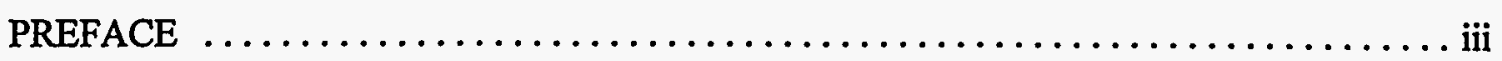

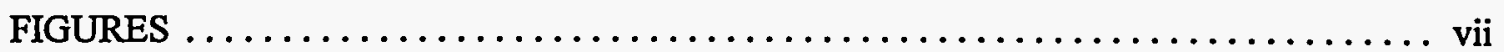

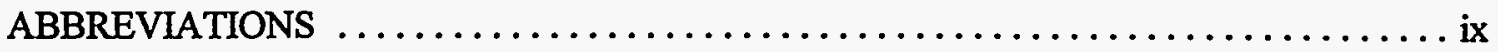

EXECUTIVE SUMMARY $\ldots \ldots \ldots \ldots \ldots \ldots \ldots \ldots \ldots \ldots \ldots \ldots \ldots \ldots \ldots \ldots$

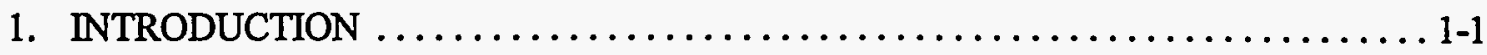

2. SUMMARY OF REMOVAL SITE EVALUATIONS $\ldots \ldots \ldots \ldots \ldots \ldots \ldots \ldots \ldots \ldots$

2.1 BUILDING 3026-C-KRYPTON-85 ENRICHMENT FACILITY . . . . . . . . 2-1

2.2 BUILDING 3026-D—SEGMENTING HOT CELL FACILITY . . . . . . . . . . . . 2-1

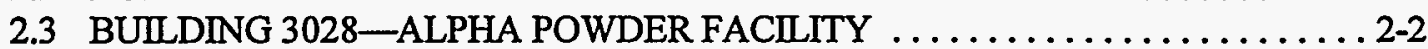

2.4 BUILDING 3029 - SOURCE DEVELOPMENT LABORATORY $\ldots \ldots \ldots \ldots . . .2-2$

2.5 BUILDINGS 3030, 3031, AND 3118-ISOTOPES PRODUCTION

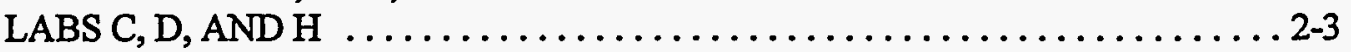

2.6 BUILDING 3032/(3099)-RADIOISOTOPES PRODUCTION

LABORATORY E ............................... 2-3

2.7 BUILDING 3033/(3093)—KRYPTON AND TRITIUM FACILITY $\ldots \ldots \ldots \ldots .2-3$

2.8 BUILDING 3033-A-ACTINIDE FABRICATION FACILITY $\ldots \ldots \ldots \ldots \ldots .2-4$

2.9 BUILDING 3034-RADIOISOTOPE AREA SERVICES BUILDING . . . . . . . 2-4

2.10 BULDING 3038 (AHF, E, M)-ISOTOPE DEVELOPMENT LABORATORY . . 2-5

2.11 BUILDING 3047-RADIOISOTOPE DEVELOPMENT LABORATORY . . . . . 2-5

2.12 BUILDING 3517-FISSION PRODUCTS DEVELOPMENT LABORATORY . . . 2-5

2.13 BUILDING 7025-TRITTUM TARGET FACILITY .............. 2-6

3. BUILDING 3026-C-KRYPTON-85 ENRICHMENT FACILITY $\ldots \ldots \ldots \ldots \ldots .1$

4. BUILDING 3026-D—SEGMENTING HOT CELL FACILITY $\ldots \ldots \ldots \ldots \ldots \ldots \ldots$ 4-1

5. BUILDING 3028-ALPHA POWDER FACILITY $\ldots \ldots \ldots \ldots \ldots \ldots \ldots \ldots \ldots$

6. BUILDING 3029-SOURCE DEVELOPMENT LABORATORY . . . . . . . . 6-1

7. BUILDINGS 3030, 3031, AND 3118-ISOTOPES PRODUCTION

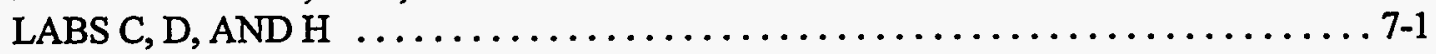

8. BUILDING 3032/(3099)-RADIOISOTOPES PRODUCTION LABORATORY E . . . 8-1

9. BUILDING 3033/(3093)-KRYPTON AND TRITIUM FACILITY $\ldots \ldots \ldots \ldots . .9$ 9-1

10. BUILDING 3033-A-ACTINIDE FABRICATION FACILITY ........... 10-1

11. BUILDING 3034-RADIOISOTOPE AREA SERVICES BUILDING ........ 11-1 
12. BUILDING 3038 (AHF, E, M)-ISOTOPE DEVELOPMENT LABORATORY . . . 12-1

13. BUILDING 3047—RADIOISOTOPE DEVELOPMENT LABORATORY . . . . . . 13-1

14. BUILDING 3517-FISSION PRODUCTS DEVELOPMENT LABORATORY . . . . . 14-1

15. BUILDING 7025-TRITIUM TARGET FACILITY $\ldots \ldots \ldots \ldots \ldots \ldots \ldots \ldots \ldots$ 15-1 


\section{FIGURES}

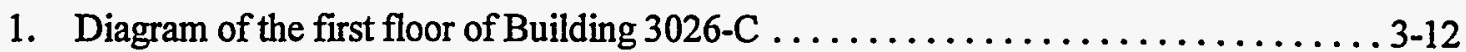

2. Diagram of the first floor of Building 3026-D (perimeter is in bold) . . . . . . . 4-12

3. Diagram of the second floor of Building 3026-D (perimeter is in bold) . . . . . . 4-13

4. Diagram of the third floor of Building 3026-D (perimeter is in bold) .......... 4-14

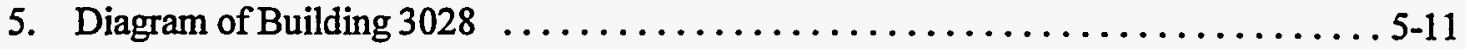

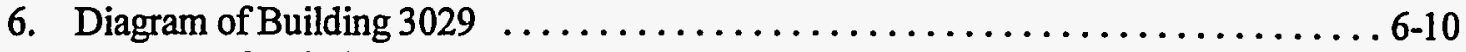

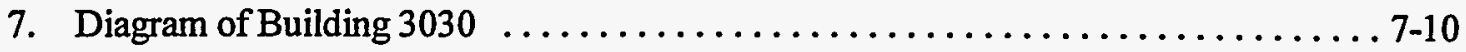

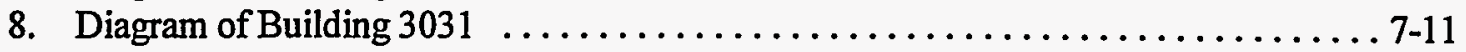

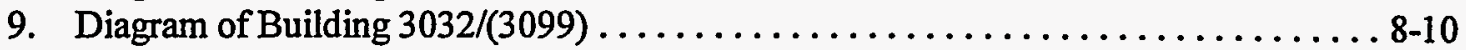

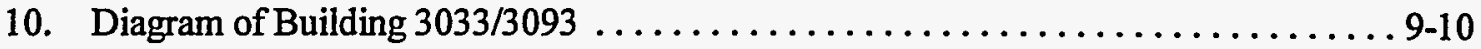

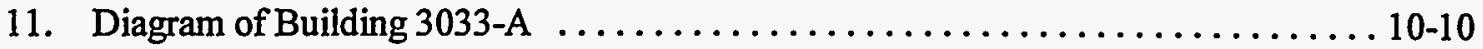

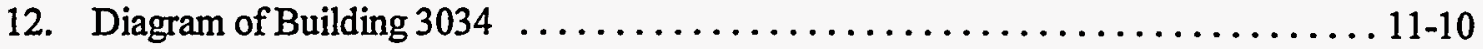

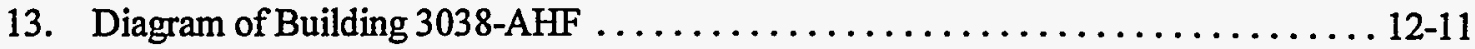

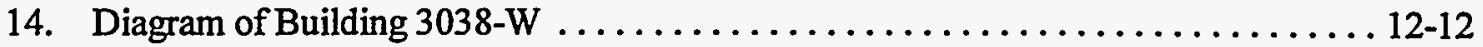

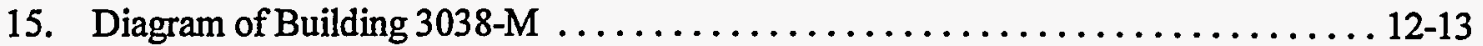

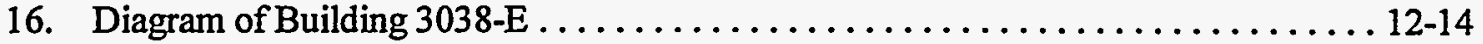

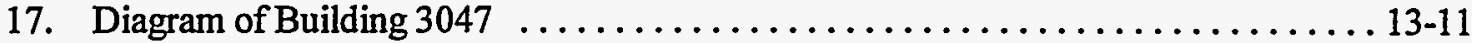

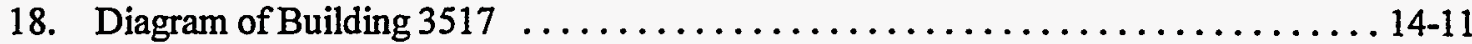

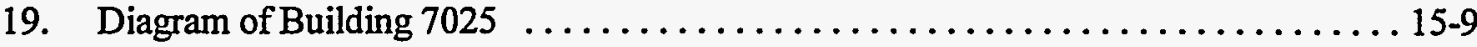


, 


\begin{tabular}{ll} 
& \multicolumn{1}{c}{ ABBREVIATIONS } \\
ACM & asbestos containing material \\
CFR & Code of Federal Regulations \\
D\&D & Decontamination and Decommissioning \\
FPDL & Fission Products Development Laboratory \\
HAZMAT & hazardous material \\
HEPA & high-efficiency particulate air (filter) \\
HSRD & Health Sciences Research Division \\
IFDP & Isotopes Facilities Deactivation Project \\
KEF & Krypton-85 Enrichment Facility \\
LBP & lead-based paint \\
LLLW & liquid low-level (radioactive) waste \\
LMES & Lockheed Martin Energy Systems, Inc. \\
ORNL & Oak Ridge National Laboratory \\
PCB & polychlorinated biphenyl \\
RAD & radiologic \\
RCRA & Resource Conservation and Recovery Act \\
RDL & Radioisotope Development Laboratory \\
RmSE & removal site evaluation \\
RSE & remedial site evaluation \\
S\&M & surveillance and maintenance \\
TCLP & Toxicity Characteristic Leaching Procedure \\
WAG & waste area grouping \\
WOC & White Oak Creek
\end{tabular}




\section{EXECUTIVE SUMMARY}

This removal site evaluation report for the Isotope Facilities at Oak Ridge National Laboratory was prepared to provide the Environmental Restoration Program with information necessary to evaluate whether hazardous and/or radiological contaminants in and around the Isotopes Facilities pose a substantial risk to human health or the environment (i.e., a high probability of adverse effects) and if remedial site evaluations or removal actions are, therefore, required. The scope of the project included (1) a review of historical evidence regarding operations and use of the facility; (2) interviews with facility personnel concerning current and past operating practices; (3) a site inspection; and (4) identification of hazard areas requiring maintenance, removal, or remedial actions.

The results of the removal site evaluation indicate that no substantial risks exist from contaminants present in the Isotope Facilities because adequate controls and practices exist to protect human health and the environment. There are, however, several maintenance actions being undertaken or proposed:

- Building 3026-C-The crawl space at the southwest corner of the facility is posted as a radiological hazard area. Openings in the foundations could allow wind or small arimals to carry contamination away from the area. Repairs are scheduled for completion by the end of July 1996.

- Buildings 3026-C and D-Paint from exterior walls and cell ventilation duct work is peeling off and has fallen to the ground. The paint is assumed to be lead based, and this poses a potential direct impact to the soil below and an indirect impact to surface water. A maintenance action will be necessary to prevent further deterioration and dislodging of the paint. Also, a remedial site evaluation should be conducted to determine whether lead from fallen paint chips has impacted the soil.

- Building 3026-D-Zinc-bromide leaking from viewing windows is being recycled back into the windows. The windows should be repaired and the leaks stopped.

- Building 3034-Paint from exterior piping is peeling off and has fallen to the ground. The paint is assumed to be lead based, and this poses a potential direct impact to the soil below and an indirect impact to surface water. A maintenance action will be necessary to prevent further deterioration and dislodging of the paint. Also, a remedial site evaluation should be conducted to determine whether lead from fallen paint chips has impacted the soil.

- Building 3047-An emergency diesel generator outside the facility may generate small quantities of fuel during repairs. Maintenance personnel have been reminded of the precautions that need to be taken to prevent spills during repairs.

- Building 7025-An underground collection tank outside the facility was reportedly the discharge point for the hot sink located in the tritium hood within the building. Reportedly, the hood did not generate liquid waste, and the contents of the tank have been removed. While no evidence of a leak exists, an internal tank inspection will be conducted by September 30, 1996.

The recommended corrective actions from the removal site evaluation are being conducted as maintenance actions; accordingly, this removal site evaluation is considered complete and terminated. 


\section{INTRODUCTION}

This removal site evaluation (RmSE) report for the Isotope Facilities at Oak Ridge National Laboratory (ORNL) was prepared to provide the Environmental Restoration Program with information necessary to evaluate whether hazardous and/or radiological contaminants in and around the Isotopes Facilities pose a substantial risk to human health or the environment (i.e., a high probability of adverse effects) and if remedial site evaluations (RSEs) or removal actions are, therefore, required. The scope of the project included (1) a review of historical evidence regarding operations and use of the facility; (2) interviews with facility personnel concerning current and past operating practices; (3) a site inspection; and (4) identification of hazard areas requiring maintenance, removal, or remedial actions.

The results of the RmSE indicate that no substantial risks exist from contaminants present in the Isotope Facilities because adequate controls and practices exist to protect human health and the environment. The recommended corrections from the RmSE (see Buildings 3026-C and D, 3034, 3047 , and 7025) are being conducted as maintenance actions; accordingly, this RmSE is considered complete and terminated. 


\section{SUMMARY OF REMOVAL SITE EVALUATIONS}

\subsection{BUILDING 3026-C-KRYPTON-85 ENRICHMENT FACILITY}

Building 3026-C is currently in an inactive, standby mode awaiting entry into the Decontamination and Decommissioning (D\&D) Program. There are no current, on-going operations in this building other than surveillance, maintenance, and deactivation activities. The building is accessed periodically by personnel to conduct various surveillance and maintenance (S\&M) and deactivation activities; otherwise, the building remains secured from public access.

There were no imminent hazard areas requiring removal actions identified inside Building 3026-C during this RmSE. Radiologic (RAD) hazard areas, asbestos containing materials (ACMs), and items containing polychlorinated biphenyl (PCBs) are marked and isolated as necessary to ensure worker safety and inadvertent release within the facility. In addition, a combination of engineering and administrative controls are in place and are enforced within the facility for worker and environmental protection. Current actions being taken to prevent further release of contamination and ensure worker safety within Building 3026-C are considered adequate until D\&D activities begin.

There were, however, two external imminent hazard areas identified to be associated with Building 3026-C. One involved the crawl space area located at the southwest corner of the facility. The area is posted as a RAD hazard area due to contaminated soil. Openings in the foundation surrounding the crawl space were observed during the site inspection. Soil in the crawl space appeared dry, with a loose surface layer. As a result, strong air movement through this area due to winds could potentially disturb the loose soil and carry contaminated particles away from the crawl space. This poses an exposure potential to personnel who might be in the immediate area during a wind episode. Additionally, these foundation openings allow access to small animals, which could become contaminated and leave the crawl space carrying contamination away from the area. Regarding the recommended maintenance action to control air movement and access in this area, a request for repair of the opening to the crawl space under Building 3026-C was prepared and is scheduled for completion by the end of July 1996.

The other imminent hazard area involves deteriorating painted, wooden exterior walls and cell ventilation duct work surfaces adjacent to the north side of the building. The paint in this building has been assumed to contain lead by the ORNL Lead Management Program based on the age of the facility. Paint in the areas mentioned is peeling off, posing a potential direct impact to the soil below and an indirect impact to surface water as a result of runoff with storm water. The paint on the building has been sampled, and the analysis is expected by the end of June 1996. If the paint contains lead, a maintenance action will be necessary to prevent further deterioration and dislodging of this paint. In addition, an RSE should be conducted to determine whether lead from fallen paint chips has impacted the soil in the immediate area. (See the Building 3026-C RmSE information form for additional information concerning these areas.)

\subsection{BUILDING 3026-D-SEGMENTING HOT CELL FACILITY}

Building 3026-D is currently in an inactive, standby mode awaiting entry into the D\&D Program. There are no current, on-going operations in this building other than surveillance, maintenance, and deactivation activities. The building is accessed periodically by personnel to 
conduct various S\&M and deactivation activities; otherwise, the building remains secured from public access.

There were no imminent hazard areas requiring removal actions identified inside Building 3026-D during this RmSE. RAD hazard areas, ACMs, and items containing PCBs are marked and isolated as necessary to ensure worker safety and inadvertent release within the facility. In addition, a combination of engineering and administrative controls are in place and are enforced within the facility for worker and environmental protection. Current actions being taken to prevent further release of contamination and ensure worker safety within Building 3026-D are considered adequate until D\&D activities begin.

There was, however, one external imminent hazard area identified to be associated with Building 3026-D. This is an area involving deteriorating painted, wooden exterior walls and cell ventilation duct work surfaces adjacent to the north side of the building. The paint in this building has been assumed to contain lead by the ORNL Lead Management Program based on the age of the facility. Paint in the areas mentioned is peeling off, posing a potential direct impact to the soil below and an indirect impact to surface water as a result of runoff with storm water. The paint on the building has been sampled, and the analysis is expected by the end of June 1996. If the paint contains lead, a maintenance action will be necessary to prevent further deterioration and dislodging of this paint. In addition, an RSE should be conducted to determine whether lead from fallen paint chips has impacted the soil in the immediate area.

It should also be noted that zinc-bromide is leaking from some of the viewing windows in the east cell bank. These leaks are currently controlled by collecting leaking fluid in a drum and pumping it back into the window. While this provides a temporary means of control and does not present an immediate threat, it is recommended that either the leaking windows be repaired and the leaks stopped or that the fluid be drained and disposed of if it is no longer needed. This will reduce or eliminate the potential for an inadvertent hazardous material (HAZMAT) release within the facility. (See Building 3026-D RmSE information form for additional information concerning these areas.)

\subsection{BUILDING 3028-ALPHA POWDER FACILITY}

Building 3028 is currently in an inactive, standby mode awaiting entry into the D\&D Program. There are no current, on-going operations in this building other than surveillance, maintenance, and deactivation activities. The building is accessed periodically by personnel to conduct various $S \& M$ and deactivation activities; otherwise, the building remains secured from public access.

There were no imminent hazard areas requiring removal actions identified to be associated with Building 3028 during this RmSE. RAD hazard areas and ACMs are marked and isolated as necessary to ensure worker safety and inadvertent release within the facility. In addition, a combination of engineering and administrative controls are in place and are enforced within the facility for worker and environmental protection. Current actions being taken to prevent further release of contamination and ensure worker safety within Building 3028 are considered adequate until D\&D activities begin.

\subsection{BUILDING 3029—SOURCE DEVELOPMENT LABORATORY}

Building 3029 is currently in an inactive, standby mode awaiting entry into the D\&D Program. There are no current, on-going operations in this building other than surveillance, maintenance, and deactivation activities. The building is occupied by personnel who are responsible for conducting 
various $S \& M$ and deactivation activities. There were no imminent hazard areas requiring removal actions identified to be associated with Building 3029 during this RmSE. RAD hazard areas, ACMs, and items containing PCBs are marked and isolated as necessary to ensure worker safety and inadvertent release within the facility. In addition, a combination of engineering and administrative controls are in place and are enforced within the facility for worker and environmental protection. Current actions being taken to prevent further release of contamination and ensure worker safety within Building 3029 are considered adequate until D\&D activities begin.

\subsection{BUILDINGS 3030, 3031, AND 3118—ISOTOPES PRODUCTION LABS C, D, AND H}

Buildings 3030,3031 , and 3118 are currently in an inactive, standby mode awaiting entry into the D\&D Program. There are no current, on-going operations in these buildings other than surveillance, maintenance, and deactivation activities. The buildings are accessed periodically by personnel to conduct S\&M and deactivation activities; otherwise, the buildings remain secured from public access.

There were no imminent hazard areas requiring removal actions identified to be associated with Buildings 3030, 3031, or 3118 during this RmSE. RAD hazard areas, ACMs, and items containing PCBs are marked and isolated as necessary to ensure worker safety and inadvertent release within these facilities. In addition, a combination of engineering and administrative controls are in place and are enforced within these facilities for worker and environmental protection. Current actions being taken to prevent further release of contamination and ensure worker safety within Buildings 3030 , 3031 , and 3118 are considered adequate until D\&D activities begin.

\subsection{BUILDING 3032/(3099)—RADIOISOTOPES PRODUCTION LABORATORY E}

Building 3032 is currently in an inactive, standby mode awaiting entry into the D\&D Program. There are no current, on-going operations in this building other than surveillance, maintenance, and deactivation activities. The building is accessed periodically by personnel to conduct S\&M and deactivation activities; otherwise, the building remains secured from public access. Building 3099 is actually a concrete pad adjacent to the west side of Building 3032 which is used for temporary storage of many different items, from equipment to containerized radioactive materials and wastes.

There were no imminent hazard areas requiring removal actions identified to be associated Building 3032 or the adjacent concrete storage pad (3099) during this RmSE. RAD hazard areas and ACMs are marked and isolated as necessary to ensure worker safety and inadvertent release within the facility. In addition, a combination of engineering and administrative controls are in place and are enforced within the facility for worker and environmental protection. Current actions being taken to prevent further release of contamination and ensure worker safety within Building 3032 are considered adequate until D\&D activities begin.

\subsection{BUILDING 3033/(3093)—KRYPTON AND TRITIUM FACILITY}

Building 3033 is currently in an inactive, standby mode awaiting entry into the D\&D Program. There are no current, on-going operations in this building other than surveillance, maintenance, and deactivation activities. The building is accessed periodically by personnel to conduct S\&M and deactivation activities; otherwise, the building remains secured from public access. Building 3093 
is a small permanent krypton storage enclosure adjacent to the northwest corner of Building 3033 which houses three empty krypton storage tanks.

There were no imminent hazard areas requiring removal actions identified to be associated Building 3033 or the adjacent concrete storage enclosure (3093) during this RmSE. RAD hazard areas and $\mathrm{ACMs}$ are marked and isolated as necessary to ensure worker safety and inadvertent release within the facility. In addition, a combination of engineering and administrative controls are in place and are enforced within the facility for worker and environmental protection. Current actions being taken to prevent further release of contamination and ensure worker safety within Building 3033 are considered adequate until D\&D activities begin.

\subsection{BUILDING 3033-A-ACTINIDE FABRICATION FACILITY}

Building 3033-A is currently in an inactive, standby mode awaiting entry into the D\&D Program. There are no current, on-going operations in this building other than surveillance, maintenance, and deactivation activities. The building is accessed periodically by personnel to conduct S\&M and deactivation activities; otherwise, the building remains secured from public access.

There were no imminent hazard areas requiring removal actions identified to be associated Building 3033-A during this RmSE. RAD hazard areas and ACMs are marked and isolated as necessary to ensure worker safety and inadvertent release within the facility. In addition, a combination of engineering and administrative controls are in place and are enforced within the facility for worker and environmental protection. Current actions being taken to prevent further release of contamination and ensure worker safety within Building 3033-A are considered adequate until D\&D activities begin.

\subsection{BUILDING 3034-RADIOISOTOPE AREA SERVICES BUILDING}

Building 3034 is currently in an inactive, standby mode awaiting entry into the D\&D Program. Building 3034 was reportedly never used for operations involving radioisotopes, although some isolated low-level areas of residual surface contamination exist. The building is being prepared for use as office space in addition to continuing to house the electrical distribution station for the Isotopes Circle area until its entry into the D\&D Program. There were no imminent hazard areas requiring removal actions identified within Building 3034 during this RmSE. RAD hazard areas and ACMs are marked and isolated as necessary to ensure worker safety and inadvertent release within the facility. In addition, a combination of engineering and administrative controls are in place and are enforced within the facility for worker and environmental protection. Current actions being taken to prevent further release of contamination and ensure worker safety within Building 3034 are considered adequate until D\&D activities begin.

There was, however, one notable, exterior, imminent hazard area identified to be associated with Building 3034. This is an area involving deteriorating, painted exterior piping adjacent to the east side of the building. The paint in this and surrounding buildings has been assumed to contain lead by the ORNL Lead Management Program based on the age of the facilities. Paint on the piping is peeling off and has fallen to the ground below. This poses a potential direct impact to the soil below and an indirect impact to surface water as a result of runoff with storm water. The paint on this piping should be sampled and analyzed for lead content to determine if, in fact, a hazard exists. If so, a maintenance action will be necessary to prevent further deterioration and dislodging of this paint. In addition, an RSE should be conducted to determine whether lead from fallen paint chips has impacted 
the soil in the immediate area. (See the Building $3034 \mathrm{RmSE}$ information form for additional information concerning this area.)

\subsection{BUILDING 3038 (AHF, E, M)-ISOTOPE DEVELOPMENT LABORATORY}

Building 3038 is currently in an inactive, standby mode awaiting entry into the D\&D Program. There are no current, on-going operations in this building other than surveillance, maintenance, and deactivation activities. The building is occupied by personnel who are responsible for conducting various $\mathbf{S} \& \mathbf{M}$ and deactivation activities.

There were no imminent hazard areas requiring removal actions identified to be associated with Building 3038 during this RmSE. RAD hazard areas, ACMs, and items containing PCBs are marked and isolated as necessary to ensure worker safety and inadvertent release within the facility. In addition, a combination of engineering/administrative controls are in place/enforced within the facility for worker and environmental protection. Current actions being taken to prevent further release of contamination and ensure worker safety within Building 3038 are considered adequate until $D \& D$ activities begin.

\subsection{BUILDING 3047-RADIOISOTOPE DEVELOPMENT LABORATORY}

Building 3047 is currently in an inactive, standby mode. All isotopes activities within Building 3047 are shut down with the exception of waste removal and transloading of radioactive material in the beta/gamma hot cells. However, a large number of different work items are currently performed within this facility. Although portions of the building are being deactivated, Building 3047 has been removed from the Isotopes Facilities Deactivation Program (IFDP), and its future use was uncertain at the time of the RmSE. The building is occupied by personnel who are responsible for conducting $S \& M$, deactivation, and various other activities.

There were no imminent hazard areas requiring removal actions identified within Building 3047 during this RmSE. RAD hazard areas, ACMs, and items containing PCBs are marked and isolated as necessary to ensure worker safety and inadvertent release within the facility. In addition, a combination of engineering and administrative controls are in place and are enforced within the facility for worker and environmental protection. Current actions being taken to prevent further release of contamination and ensure worker safety within Building 3047 are considered adequate.

There was, however, one notable, exterior, imminent hazard area identified to be associated with Building 3047. This is an area involving the emergency diesel generator adjacent to the north side of the facility. A follow-up inspection of the diesel generator was conducted, and no leak was found. During routine maintenance, small quantities of fuel may be generated. Maintenance personnel have been reminded of precautions that need to be taken to prevent spills of fuel while performing repairs to the generator. No other actions are planned. (See the Building $3047 \mathrm{RmSE}$ information form for additional information concerning this area.)

\subsection{BUILDING 3517-FISSION PRODUCTS DEVELOPMENT LABORATORY}

Building 3517 is currently in an inactive, standby mode awaiting entry into the D\&D Program. There are no current, on-going operations in this building other than surveillance, maintenance, and 
deactivation activities. The building is occupied by personnel who are responsible for conducting various $S \& M$ and deactivation activities.

There were no imminent hazard areas requiring removal actions identified to be associated with Building 3517 during this RmSE. RAD hazard areas, ACMs, and items containing PCBs are marked and isolated as necessary to ensure worker safety and inadvertent release within the facility. In addition, a combination of engineering and administrative controls are in place and are enforced within the facility for worker and environmental protection. Current actions being taken to prevent further release of contamination and ensure worker safety within Building 3517 are considered adequate until D\&D activities begin.

\subsection{BUILDING 7025-TRITIUM TARGET FACILITY}

Building 7025 is currently in an inactive, standby mode awaiting entry into the D\&D Program. There are no current, on-going operations in this building other than surveillance, maintenance, and deactivation activities. The building is accessed periodically by personnel to conduct S\&M and deactivation activities; otherwise, the building remains secured from public access.

There were no imminent hazard areas requiring removal actions identified to be associated with Building 7025 during this RmSE. RAD hazard areas and ACMs are marked and isolated as necessary to ensure worker safety and inadvertent release within the facility. In addition, a combination of engineering and administrative controls are in place and are enforced within the facility for worker and environmental protection. Current actions being taken to prevent further release of contamination and ensure worker safety within Building 7025 are considered adequate until D\&D activities begin.

It should be noted, however, that an underground collection tank exists adjacent to the east side of the facility. This tank was reportedly the discharge point for the hot sink located in the tritium hood within the facility. It was also reported that the processes in this hood did not generate liquid waste; therefore, the sink was only used by personnel for washing and decontamination. The contents have reportedly been removed, and the tank currently sits empty. No evidence was identified during this RmSE to indicate whether or not the tank has leaked. An internal tank inspection will be conducted by September 30, 1996. Based upon this inspection, additional actions may be merited. (See the Building $7025 \mathrm{RmSE}$ information form for additional information concerning this area.) 

ORNL FACILITY RmSE INFORMATION FORM

\begin{tabular}{|c|c|c|}
\hline \multicolumn{3}{|c|}{ General Information } \\
\hline \multicolumn{3}{|c|}{$\begin{array}{ll}\text { Area/Facility Name } & \\
\text { (and aliases): } & \text { Building 3026-C } \\
& \text { Krypton-85 Enrichment Facility (KEF) }\end{array}$} \\
\hline \multicolumn{3}{|c|}{$\begin{array}{l}\text { Organization responsible for area/facility } \\
\text { (include specific person and phone number if possible): R.E. Eversole (576-7483), } \\
\qquad \begin{array}{l}\text { IFDP Project Manager, } \\
\text { ER Program, LMES }\end{array}\end{array}$} \\
\hline Status (active/inactive): & Inactive, Standby Mode & Years of Operation: $\approx 45$ \\
\hline \multicolumn{3}{|c|}{$\begin{array}{l}\text { Description of Operation: } \\
\text { There are no current operations, other than surveillance, maintenance, and deactivation activities, on-going } \\
\text { in this building. Historical operations included development of methods for isolating fission products and } \\
\text { radioisotope processing for research and medical purposes. Waste from processing irradiated reactor fuel } \\
\text { elements for uranium and plutonium recovery in Building } 3019 \text { was piped directly to Building } 3026-\mathrm{C} \text { where } \\
\text { it was processed to isolate short-lived isotopes. Radiologic elements processed in Building } 3026-\mathrm{C} \\
\text { included }{ }^{129} \mathrm{I},{ }^{131} \mathrm{I},{ }^{79} \mathrm{Se},{ }^{107} \mathrm{Pd},{ }^{147} \mathrm{Pm},{ }^{137} \mathrm{Cs},{ }^{90} \mathrm{Sr},{ }^{60} \mathrm{Co},{ }^{3} \mathrm{H},{ }^{85} \mathrm{Kr},{ }^{188} \mathrm{~W} \text {, and }{ }^{191} \text { Os. Radioisotope processing and } \\
\text { handling was performed primarily in contained hot cells and lab hoods. Resulting primary waste streams } \\
\text { from these processes included exhausted air and liquid process waste. }\end{array}$} \\
\hline \multicolumn{3}{|c|}{$\begin{array}{l}\text { Physical description of areaffacility: } \\
\text { - Building } 3026-C \text { was originally constructed in } 1943 \text {. } \\
\text { This facility is a two-story, wooden frame building. Portions of the exterior of the building are sided } \\
\text { with metal. Paint on metal exterior surfaces is in good condition. Paint on exposed wooden exterior } \\
\text { surfaces is deteriorating and in poor condition (particularly on the north wall). } \\
\text { Paint on exhaust duct work located adjacent to the north wall of the building is deteriorating in localized } \\
\text { areas. } \\
\text { Building } 3026-C \text { is physically connected to Building } 3026-D \text {, which is to the east. The two buildings } \\
\text { share utilities (electric, steam, plant air). } \\
\text { Building } 3026-C \text { is located in an industrial area of ORNL, adjacent to Isotope Circle. The immediate } \\
\text { area surrounding the facility is paved for the most part with some grassy areas, particularly on the north } \\
\text { side of the building. } \\
\text { The building contains office space, laboratories, hot cells, and process areas. There are two hot cell } \\
\text { banks consisting of } 4 \text { cells each, located in the central portion of the building. The viewing windows } \\
\text { of the hot cells were filled with zinc-bromide. The fluid from all but one window has been drained and } \\
\text { removed from the facility. Floor drains in the cells discharge to the low-level liquid waste (LLLW) } \\
\text { system (tanks W-17 and W-18). The cells are currently shutdown. Work with radioactive materials was } \\
\text { performed in the hot cells, laboratories, counting room, and tritium facility. } \\
\text { Some interior portions of the building are restricted access areas due to radiologic contamination. } \\
\text { Generally, the interior of the building is in fair to good condition. Asbestos Containing Material } \\
\text { (ACM), radiation (RAD) hazard areas, and polychlorinated bi-phenol (PCB) containing equipment are } \\
\text { posted and/or labeled as appropriate. } \\
\text { The hot cells are kept under negative pressure relative to the interior of the building. The building itself } \\
\text { is not sealed. } \\
\text { A building space diagram is attached to this form showing the locations of the various process areas and } \\
\text { equipment. }\end{array}$} \\
\hline
\end{tabular}




\begin{tabular}{|c|}
\hline Release Information \\
\hline Description of release, or threatened release, and source:
\end{tabular}

Low levels of residual fixed and transferable radiologic surface contamination exist in areas of the facility as a result of historical operations. The contamination exists primarily in the hot cells and process equipment (vessels, hoods, piping, ventilation ducts, etc.). This contamination has accumulated from activities involving a variety of materials throughout the operating history of the facility and, therefore, cannot be attributed to a single release episode. The existing levels of RAD contamination in the facility are low and the presence of this contamination is not considered a significant hazard in its current state.

Hazardous materials (HAZMATs) (e.g., acids, hydraulic fluids, and other chemicals) were reportedly used in small quantities (i.e., less than 5 gallons or 100 pounds) during facility operations and currently for surveillance and maintenance (S\&M) activities. According to available spill/release records and facility personnel interviews, no significant HAZMAT spills (i.e., spills having the potential to adversely affect human health and/or the environment) have been reported for this building. No current conditions were identified which present a potential for a significant HAZMAT release.

Hazardous substances present:

Hazardous substances remaining in Building 3026-C consist mainly of residual RAD surface contamination $(\alpha, \beta, \gamma)$, zinc-bromide, PCBs, and a small quantity of miscellaneous HAZMATs. Areas of fixed and transferable RAD contamination are associated primarily with the hot cells and process equipment. Zinc-bromide remains present in one hot cell viewing window. PCBs are present in electrical capacitors within the building. Hazardous materials present in the building are listed on the attached HAZMAT inventory sheet.

Estimate (if possible) of quantities of hazardous substances that have been released and that could be released:

The following represents the known quantities of substances currently existing in the facility. Radiologic surface contamination has accumulated from a legacy of many different programs and processes and cannot be attributed to a single release episode. It is only possible to quantify release amounts from contamination which currently exists in the facility and/or has been historically documented from past activities.

$<1 \mu \mathrm{Ci} \alpha$ contamination in facility - not identified by individual isotope.

$<10 \mu \mathrm{Ci}$ fission products - including ${ }^{137} \mathrm{Cs}$, ${ }^{85} \mathrm{Kr}$ and ${ }^{60} \mathrm{Co}$.

$<100 \mu \mathrm{Ci}{ }^{3} \mathrm{H}$ (tritium).

$\approx 50$ gallons zinc-bromide (estimated based on size of viewing window).

$\approx 1.25$ gallons $\mathrm{PCBs}$.

$\approx 320$ pounds total miscellaneous HAZMATs (see attached HAZMAT inventory sheet).

(Quantity estimates obtained from Building 3026-C Hazard Screening Report, ORNL PCB Large High- and Low-Voltage and Small Capacitor Inventory database, ORNL Hazardous Material Information System database.) 
Other pollutants or contaminants:

Asbestos containing material, primarily in the form of thermal system insulation, has been confirmed present in this building. ACM observed is in fair to good condition and poses no immediate health threat. Based on the age of the facility, interior and exterior painted surfaces are assumed to be lead-containing. Verification samples are taken by ORNL Lead Management Program personnel on an "as-needed" basis to confirm the presence of lead in the paint (i.e., when work activities will disturb the paint, or paint is found to be deteriorating and poses a health or environmental threat). Interior painted surfaces observed are in fair to good condition and pose no immediate health threat. Paint on exterior wood surfaces (particularly the north side of the building) and exterior cell ventilation duct work is chipped and flaking off to the ground below in some areas. According to the ORNL Lead Management Office, no verification samples of this paint have been taken and analyzed; therefore, the area remains assumed to contain lead.

\section{Groundwater}

Are there any suspected impacts to groundwater? If yes, please describe. Include any impacts to drinking water sources.

Building 3026-C is located in Waste Area Grouping 1 at ORNL. Although no specific adverse spills or releases of hazardous substances were identified during this RmSE, it is suspected, based on available environmental studies conducted in WAG 1, that process and LLLW drains and associated piping may have leaked over the life of the facility. Buried process and LLLW piping and some drains have been found to be deteriorated and leaking in other facilities and areas of WAG 1 . Studies have determined that groundwater in WAG 1 has been both radiologically and chemically contaminated. Numerous man-made radionuclides have been detected in WAG 1 groundwater samples including many of those processed in Building 3026-C. It is likely that liquid waste from activities involving radioisotopes in Building 3026-C have historically contributed to WAG 1 groundwater contamination. However, the radionuclides detected in the groundwater were common to the processes and activities in many other buildings in the area which makes it difficult to determine exactly which building is, or was, the source of contamination.

Because of the reported small quantities of chemicals historically used in this facility, it is unlikely that such usage has significantly contributed to WAG 1 groundwater contamination. As part of the facility shutdown process, inactive process and LLLW drains within the building have reportedly been plugged to prevent further release. However, no documentation was available at the time of this report to verify which drains have actually been plugged and which have not. Information on drain locations and discharge points is available from the ORNL Engineering Support Office.

Although it is not impossible, it is unlikely that groundwater has been, or will be, impacted by the flaking and chipping exterior paint located on the north side of the building if, in fact, it is lead-containing. Because of the depth to the water table in the area of Building 3026-C $(\approx 20 \mathrm{feet})$ and physical characteristics of soil in the area, it is doubtful that any significant amount of lead has, or will, reach the groundwater through percolation with storm water and vertical migration.

Other than the potential for historical impact to groundwater in WAG 1 via leaking process and LLLW lines external to the building, no existing immediate threat to groundwater was identified given the current status of the facility. 


\section{Surface Water}

Are there any suspected impacts to surface water? If yes, please describe. Also describe the most likely surface water migration route(s), if applicable. Include any impacts to drinking water sources.

WAG 1 is essentially bound by Fifth Creek to the east, White Oak Creek (WOC) to the south, and First Creek to the west. First and Fifth creeks flow south into (WOC) which flows to the west and exits WAG 1 at the southwest corner. Stormwater (from surface runoff and stormwater drainage system) and treated water from the process waste system discharges into WOC. The only potential for direct impact to surface water from Building 3026-C in its current state would be from lead-containing paint chips which fall off the first and second story exterior painted surfaces and find their way into the stormwater drainage system and eventually to WOC. The apron around the north side of the building is gravel and grass below the areas of deteriorating paint. Peeling paint from the second story of the building in this area could fall off onto the first story roof and could get washed off the roof through the roof drains with stormwater. The roof drain in this area spills to the surface of the north-central portion of the building apron. This area of the apron is a restricted area and was not accessible during the building inspection. No storm drains were observed in this area from a distance; however, if a storm drain exists, there is a potential that paint chips could migrate to WOC through the stormwater drainage system.

Surface water may have also been indirectly impacted by leaking process and LLLW lines external to the building. Some of these lines are known to have shared a common trench with stormwater drainage piping. Contamination from leaking waste lines could potentially enter deteriorated stormwater piping and migrate to WOC. The three creeks bordering WAG 1 are groundwater discharge points. Therefore, groundwater contaminated by leaking waste lines could also potentially impact surface water in the area.

Other than the potential for historical impact, the only existing immediate threat to surface water identified during this RmSE is that from the assumed lead-containing paint at the north of the building.

\section{Air}

Are there any suspected impacts due to air emissions? If yes, please describe.

The Hazard Screening Report prepared for Building 3026-C indicates a slight potential for radiation exposure to personnel working inside and within the immediate vicinity of the facility exists due to potential airborne migration of radioactive particulates and physical contact with contaminated surfaces. Areas of RAD contamination are identified, marked, and controlled as appropriate throughout the facility to protect against inadvertent exposure to personnel. Air flow in the building is controlled by the design of the ventilation system which moves air from areas with a low potential for contamination through areas with a higher potential for contamination and exhausts the air through the Isotopes Circle cell ventilation system to stack 3039. Apart from catastrophic failure of the hot cells or cell ventilation system, it is unlikely that radioactive air emissions from Building 3026-C would impact personnel or the environment in its current state. An additional potential for air quality impact outside the building exists as a result of air movement through the crawlspace below the building (see discussion in Soil section of this report).

There is also a potential for impact to indoor air quality due to the presence of ACM and assumed lead-based paint (LBP) should these materials be disturbed. The ACM and assumed LBP remaining in the building are not considered to be immediate threats to indoor quality in their current state. 
Soil

Are there any suspected impacts to soil? If yes, please describe.

The only existing immediate threat to soils identified in the area of Building $3026-\mathrm{C}$ is located adjacent to the north side of the facility. Paint on the exterior of the north wall is badly deteriorated and is peeling off the building. Paint on the cell ventilation system duct work in this area also shows evidence of localized deterioration. This paint is assumed to contain lead by the ORNL Lead Management Office. The soil in this area is at risk of being impacted by lead contamination from paint that has peeled or chipped off the wall or duct work if, in fact, the paint does contain lead.

There is also evidence that soil beneath the building has been historically impacted by radiologic contamination. Postings at the entry points to the building's crawlspace indicate radioactive soil contamination in the crawlspace. Access to the crawlspace is restricted; however, it is not controlled. Access doors to the crawlspace were found to be open leaving the area easily accessible should the RAD warning sign be removed somehow (by strong wind, for example). In addition, soil in the crawlspace was observed to be very dry with a loose surface. Openings in the building's foundation can allow wind to enter the crawlspace stirring up potentially contaminated dust which can subsequently exit the crawlspace through these openings. This would pose a pathway for migration of radiologic contamination as well as a potential airborne contamination hazard to those in the immediate area during a wind episode. These openings could also allow small animals to enter the crawlspace and become contaminated internally and externally from dust. Contamination could then migrate from the crawlspace in the animals coat, fecal matter, urine, and decaying body upon death.

As stated for groundwater, there is also a potential for historical impact to soils in the area of Building 3026$\mathrm{C}$ due to leaking process and LLLW drain piping. Previous environmental studies have identified a soil contamination plume in the Isotopes Circle area and soil samples collected from the plume have detected radioisotopes common to the processes performed in Building 3026-C. Whether waste from Building 3026-C has actually contributed to this contamination is unknown, given the information reviewed during this RmSE. It is unlikely that the small quantities of chemicals used in Building 3026-C have significantly impacted soil in the surrounding area.

Release Beyond Facility or Reservation Boundaries

Has or will the release migrate beyond the boundaries of the facility or reservation? If yes, please describe (including possible human or environmental receptors).

The following are considered potential scenarios where radiologic contamination could migrate beyond the facility or reservation boundaries:

- Contaminated dust in the building crawlspace becomes airborne and carried away due to wind blowing through openings in the foundation.

- An animal enters the crawlspace, becomes contaminated, and leaves carrying the contamination away.

- A person becomes inadvertently contaminated and leaves the facility/reservation undetected.

- Catastrophic failure of hot cells and/or contaminated equipment.

There is also a potential for assumed lead-containing paint which peels off the north side of the building to be carried away with surface runoff during a rain event. Though these potentials exist, they are considered slight and unlikely due to the current status of the facility and the engineering/administrative controls that are in place to protect again such an event. 


\section{Worker Safety}

Could the release pose a threat to workers? If yes, please describe.

Radiologically contaminated areas are isolated and well marked. Good radiation practices and standard operating procedures are enforced for worker safety. Personnel exiting the facility are required to "frisk" themselves to detect the presence of RAD contamination. Monitors and alarms are in place to detect any radioactive release within the building. PCB containing equipment and ACM are appropriately labeled. However, even with these safeguards in place, a potential threat to workers exists if safety measures are overlooked. This potential is not considered significant given the current status and level of activity of the building.

\section{Environmental Receptors}

Does the release pose a potential threat to environmental receptors? If yes, please describe. Include natural resources impacts.

The following are the potential environmental receptors of contamination resulting from any potential releases discussed in this form:

- Animals - Vermin which find their way into the contaminated crawlspace.

The potential for impact to this receptor is considered slight.

No other existing conditions posing an immediate significant threat to environmental receptors, including natural resources, were identified to be currently associated with Building 3026-C.

\section{Mitigation}

What action(s) might be taken to abate/prevent release or impacts from release?

- Continued utilization and enforcement of engineering and administrative controls that are currently in place to protect workers and monitor conditions and activities in the building.

- Openings in the foundation surrounding the crawlspace should be boarded up and sealed to prevent vermin access and minimize air movement through the space.

- Exterior paint on the north wall of the facility and on cell ventilation system duct work in the area should be tested for lead content. If the paint is found to be lead-containing, a maintenance action will be required to eliminate areas of deteriorating paint. In addition, a remedial site evaluation will be necessary to determine whether the soil in this area has been impacted by lead from the peeling paint.

- Continue S\&M activities per Procedure IP-900. 
What actions are currently being taken to abate/prevent release or impacts from release?

Engineering and administrative controls are in place to control access to contaminated areas and to monitor conditions and activities within the facility for worker and environmental protection. Warning signs and labels are posted throughout the facility indicating RAD, ACM, and PCB hazard areas. Standard operating procedures are in place for building access and surveillance and maintenance activities to protect against inadvertent contact and disturbance of contaminated areas and materials. Radiologically contaminated areas are monitored periodically by ORNL health physics personnel. Personnel are "frisked" upon exit of the facility to detect the presence of radiologic contamination. The building is currently in surveillance and maintenance status awaiting entry into the D\&D Program. Inactive waste drains are reportedly plugged in contaminated areas to prevent inadvertent discharge of contamination beyond the facility. A groundwater monitoring program is in place to monitor contamination levels and migration in groundwater underlying WAG 1. The building is inspected for structural changes after each natural incident (earthquake, tornado, or other severe storm), fire and/or man induced activity which could cause cracking, failure, or deterioration of the facility and/or equipment that may allow contamination to be released. No such conditions have been reported for Building 3026-C.

With the exception of the crawlspace and deteriorating areas of exterior paint, current actions being taken to prevent further release and ensure worker safety in Building 3026-C are considered adequate until D\&D activities begin.

Other Environmental Authorities

Is the release or threatened release potentially subject to other environmental statutory actions? If yes, please explain.

If paint is found to be lead-containing and samples fail the Toxicity Characteristic Leaching Procedure (TCLP) analysis, the building could qualify as a hazardous waste generator point under the Resource Conservation and Recovery Act (RCRA).

Maintenance Actions

Are maintenance actions necessary to eliminate potential threats to human health and the environment?

If so, explain.

Access to the contaminated crawlspace should be controlled. The area is presently marked with RAD warning signs at each access. While this should prevent human access, wind and vermin can still enter the area, potentially stirring up contaminated dust. All openings in the foundation surrounding the crawlspace should be sealed to prevent air movement and vermin access.

Samples should be taken of the exterior paint located on the north wall of the facility and adjacent cell ventilation duct work. The samples should then be analyzed to determine whether the paint does, in fact, contain lead. Such analysis should include TCLP (40 CFR 261, Appendix II) to determine whether Building 3026-C qualifies as a RCRA generator point. If the paint is found to contain lead, abatement actions will be required to prevent deteriorated areas of paint from dislodging and falling to the ground below, potentially having a direct impact on soil in this area.

No further potential hazards requiring maintenance actions were identified to be associated with Building 3026-C. 
Removal Actions

Are Removal Actions necessary to eliminate immediate threats to human health and the environment? If so, explain.

No imminent hazards requiring removal actions per 40 CFR 300.415 were identified to be currently associated with Building 3026-C.

\section{Remedial Site Evaluation}

Is a Remedial Site Evaluation needed?

Pending confirmatory sampling and analysis results of the exterior paint in the north area of the facility, a Remedial Site Evaluation (RSE) should be conducted to determine whether the soil in this area has been impacted by lead from chipping paint and whether remediation of the soil is necessary.

Areas of radiologic contamination associated with Building 3026-C have been identified and marked as appropriate. However, it is suspected that process and LLLW drains and associated piping may have leaked beneath the slab of the building as a result of past practices. As a result, it is recommended that some type of remedial investigation be performed to assess the condition of the soil in this area before conducting any $S \& M$ or $D \& D$ activities which involve disturbing the slab.

ACM and PCB-containing equipment have also been identified, marked and documented. No further remedial investigation involving these hazards is considered necessary given the current status and future plans of this facility.

Based on the age of the facility, painted surfaces are assumed to contain lead. Samples of the paint should be taken and analyzed to verify the presence of lead prior to conducting any S\&M or D\&D activities which may disturb these assumed areas.

\section{No Further Investigation}

Is a finding of No Further Investigation appropriate? Please explain.

A finding of No Further Investigation implies that a facility or area is free from hazardous substances or contaminants that may threaten human health and the environment. Since Building 3026-C contains substances and materials which may become threatening if not properly controlled, handled and managed during the S\&M cycle, a finding of No Further Investigation is inappropriate in this case. 
Additional Comments

The following documents and databases were referenced for historical and hazard information related to Building 3026-C:

- Phase I Safety Documentation, The Krypton-85 Enrichment Facility, Building 3026-C, Hazard Screening, Document No. HS/3026-C/F/RT-4 (Rev. 0).

- Work Plan for the Isotopes Facilities Deactivation Project at Oak Ridge National Laboratory, Document No. ORNL/ER-249/R2.

- Building 3026-C Occurrence Reports, 1989 to present.

- Site Characterization Summary Report for Waste Area Grouping 1 at Oak Ridge National Laboratory, Oak Ridge, Tennessee, Volumes 1 and 2, Document Nos. DOE/OR-1043/V1\&D1 and DOE/OR1043/V2\&D1.

- ORNL Hazardous Material Information System Database.

- ORNL Drain System Survey Report for Building 3026-C.

The following personnel and offices were contacted and provided historical and current use/condition information for Building 3026-C:

- Mr. Karl Haff, Radiochemical Processing Department Head, ORNL Radiochemical Technology Section.

- Mr. Herman Phillips, Assistant Facilities Manager, ORNL Special Projects.

- Ms. Swati Wilson, Manager, ORNL Lead Management Program.

- Mr. Nathan Dunn, Hazardous Material Information System Office.

- Mr. Jade Thomas, ORNL Environmental Compliance Office.

- Mr. Joe Armento, ORNL Chemical Technology Division, Isotopes Facilities Shutdown Program.

The RmSE of this facility was conducted for LMES under contract by:

Advanced Sciences, Inc.

800 Oak Ridge Turnpike, Suite C-102

Oak Ridge, TN

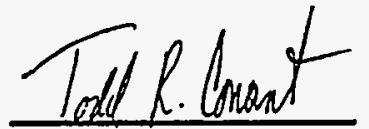

Evaluator's Signature

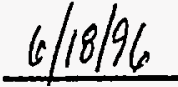

Date 
ORNL DWG 90-600

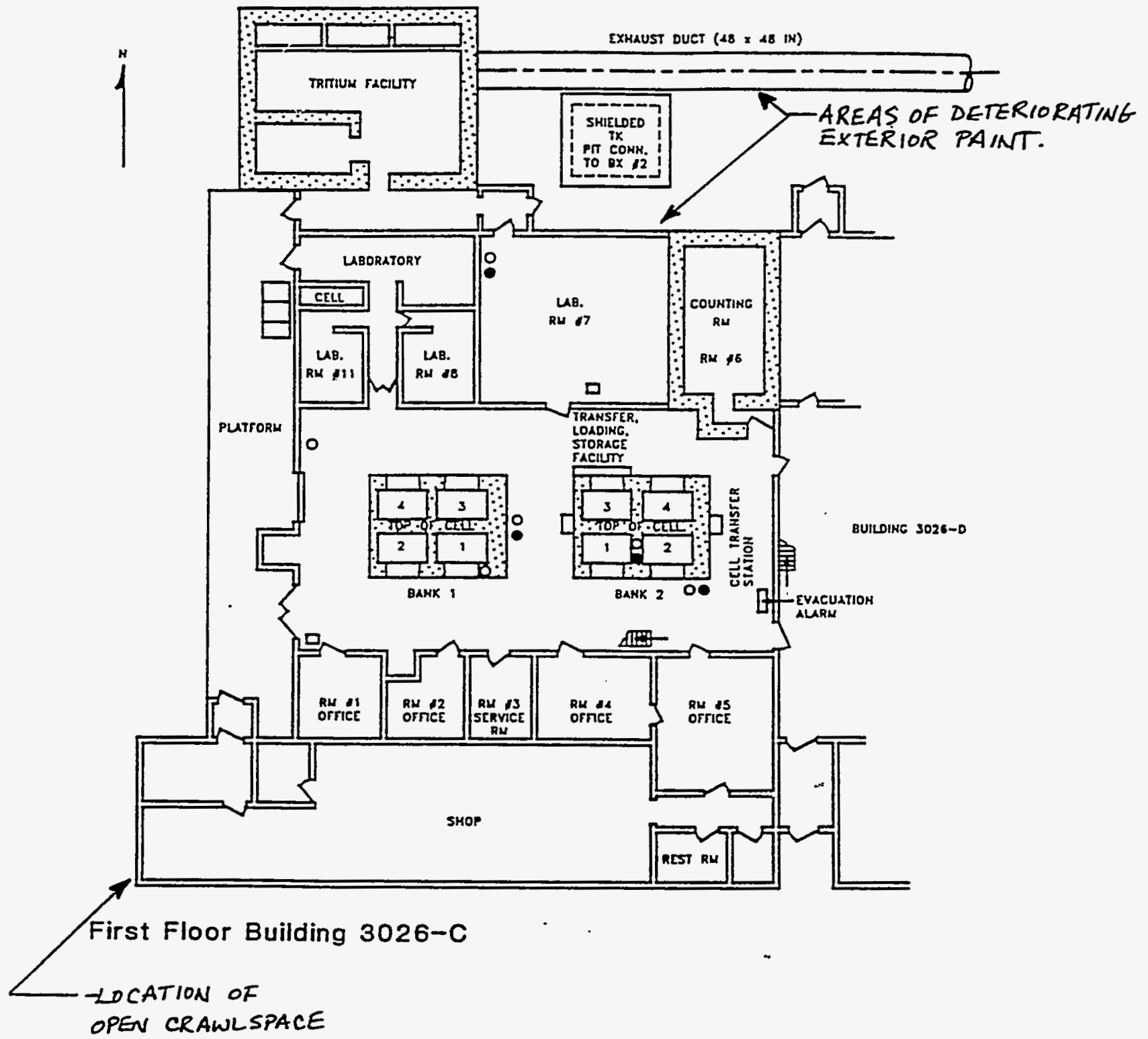

Fig. 1. Diagram of the first floor of Building 3026-C. 
HIM

$13: 52: 53$

Plant: 3 Division:

Date Expiration:
$03-28-1996$
HAZARDOUS MATERIALS INFORMATION SYSTEM Management Inventory Summary Report (by Building)

Department : Control Area: Building : $3026 \mathrm{C}$

Room: Mix Comp: Ingredient:
MSDS Avail:
Area:

Area :

ass: HẢ Rating:

Pressure Cd: Temp Cd: Cont Type Cd:

\section{Building: $3026 \mathrm{C}$}

\begin{tabular}{lll} 
RECID & $*$ CASNO \\
\hline A2379 & -- & NISS \\
91609 & NISS \\
91614 & NISS \\
83616 & NISS \\
A0222 & \\
90784 & NISS \\
A4163 & NISS \\
A0407 & NISS \\
A9536 & NISS \\
82502 & NISS \\
B2688 & NISS \\
04624 & N07727-37-9 \\
94913 & NISS \\
06541 & NISS \\
91196 & NISS
\end{tabular}

\section{Material Name}

Material Name

BUFFER SAL PRODUCTS PH 10.00 CALIBRATING BUFFER

BUFFER SOLUTION (PHOSPHATE)

BUFFER SOLUTION PH 10.00

DEVCON 5-MINUTE EPOXY HARDENER (91081) AND RESIN(90

HACH FORMAZIN TURBIDITY STANDARD 4000 NTU

HORIBA INSTRUMENTS POTASSIUM CHLORIDE SOLUTIONS

JOHNSON MATTHEY PALLADIUM ON ALUMINA

MESTER 970 FLUX

AEROSOL

MYRON L COMPANY TDS/CONDUCTIVITY STANDARD SOLUTION MYRON

作 PUAT

Building 3026C Totals:

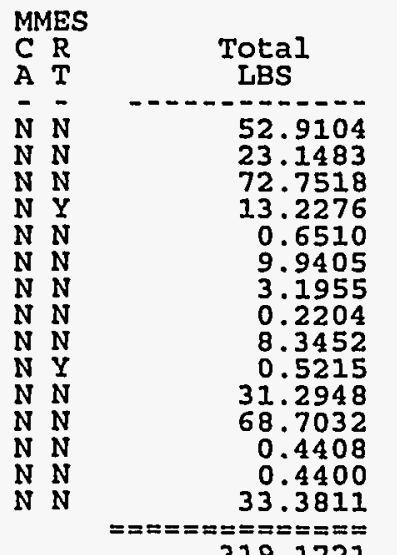

319.1721
UISCLASSIFIED Page:
Installation: oRNL

WA Code:

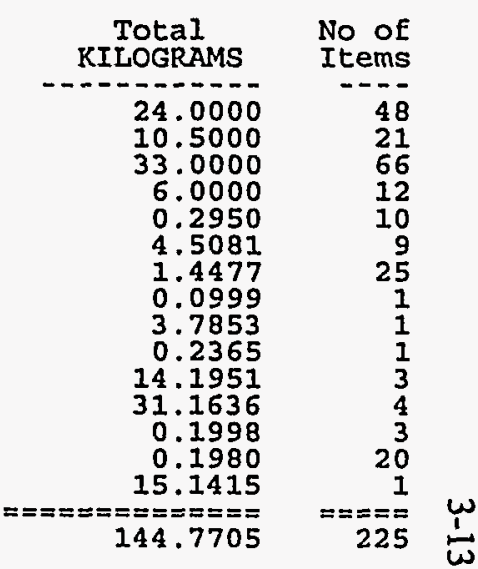

- indicates MSDS is not available

* indicates MSDS updated within last three months 

4. BUILDING 3026-D-SEGMENTING HOT CELL FACILITY 


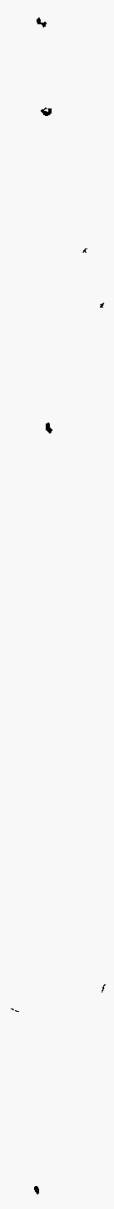




\section{ORNL FACILITY RmSE INFORMATION FORM}

\begin{tabular}{|c|c|}
\hline \multicolumn{2}{|c|}{ General Information } \\
\hline $\begin{array}{l}\text { Building 3026-D } \\
\text { Segmenting Hot Cell Facility }\end{array}$ & \\
\hline \multicolumn{2}{|c|}{$\begin{array}{ll}\text { Organization responsible for arealfacility } & \\
\text { (include specific person and phone number if possible): } & \text { R.E. Eversole (576-7483), } \\
& \text { IFDP Project Manager, } \\
& \text { ER Program, LMES }\end{array}$} \\
\hline Inactive, Standby Mode & Years of Operation: $\approx 40$ \\
\hline \multicolumn{2}{|c|}{$\begin{array}{l}\text { Description of Operation: } \\
\text { There are no current operations, other than surveillance, maintenance, and deactivation activities, on-going } \\
\text { in this building. Building } 3026-\mathrm{D} \text { houses a high-level radioactivity storage facility and a Chemical } \\
\text { Separation Laboratory in addition to the Segmenting Hot Cells Facility. Historically, the Chemical } \\
\text { Separations Laboratory has served as a facility for the production of }{ }^{32} \mathrm{P} \text { and }{ }^{131} \mathrm{I} \text {; separation of numerous } \\
\text { fission products; isolation of }{ }^{99} \mathrm{~T},{ }^{147} \mathrm{Pm} \text {, and }{ }^{237} \mathrm{~Np} \text {; and the isolation of }{ }^{135} \mathrm{Xn} \text { for neutron cross-section } \\
\text { determination. The Segmenting Hot Cells Facility was originally used to isolate large quantities of } \\
\text { fission-produced }{ }^{140} \mathrm{Ba} \text { for criticality testing purposes. The cells in the Segmenting Hot Cells Facility have } \\
\text { been greatly modified since the }{ }^{140} \mathrm{Ba} \text { process was discontinued. They now provide facilities for the } \\
\text { segmenting, examination, and assembly of irradiated metallurgical specimens which remain in storage } \\
\text { within the facility. Radioisotope processing and handling was performed primarily in contained hot cells. } \\
\text { Resulting primary waste streams from these processes included exhausted air and liquid process waste. }\end{array}$} \\
\hline $\begin{array}{l}\text { Physical description of area/facility: } \\
\text { - Building } 3026-\mathrm{D} \text { was originally constructed in the lat } \\
\text { - The facility is a three-story, wooden frame building. } \\
\text { with metal. Paint on metal exterior surfaces is in go } \\
\text { surfaces is deteriorating and in poor condition (partic } \\
\text { - Paint on exhaust duct work located adjacent to the nor } \\
\text { areas. } \\
\text { Building } 3026-\mathrm{D} \text { is physically connected to Building } \\
\text { share utilities (electric, steam, plant air). } \\
\text { Building } 3026-\mathrm{D} \text { is located in an industrial area of } \\
\text { area surrounding the facility is paved for the most par } \\
\text { side of the building. } \\
\text { The building contains office space, changing rooms, } \\
\text { The principle structure within the building is a two-st } \\
\text { into two connecting radioactive material handling c } \\
\text { (Cell A and Cell B-1/2). The west face of the } \\
\text { zinc-bromide filled viewing windows. To the we } \\
\text { high-level radioactivity storage facility. This facility } \\
\text { tunnel below the floor for material transfer purpos } \\
\text { discharge to the low-level liquid waste (LLLW) sy } \\
\text { down. Work with radioactive materials was perform }\end{array}$ & $\begin{array}{l}\text { 40s. } \\
\text { tions of the exterior of the building are sided } \\
\text { ondition. Paint on exposed wooden exterior } \\
\text { y on the north wall). } \\
\text { all of the building is deteriorating in localized } \\
\text { 6-C, which is to the west. The two buildings } \\
\text { L adjacent to Isotope Circle. The immediate } \\
\text { h some grassy areas, particularly on the north } \\
\text { ess areas, hot cells, and associated equipment. } \\
\text { 5-ft thick concrete cell block which is divided } \\
\text { (hot cells) located in a north-south direction } \\
\text { block is equipped with manipulators and } \\
\text { the cell block, located at floor level is the } \\
\text { onnected to the south hot cell (Cell A) via a } \\
\text { Floor drains in the cells and hood hot sinks } \\
\text { (Tank W-16). The cells are currently shut } \\
\text { imarily in the hot cells. }\end{array}$ \\
\hline
\end{tabular}


Physical description of arealfacility (Continued):

- Some interior portions of the building are restricted access areas due to radiologic contamination. Generally, the interior of the building is in poor to fair condition. Asbestos Containing Material (ACM), radiation (RAD) hazard areas, and polychlorinated bi-phenol (PCB) containing equipment are posted and/or labeled as appropriate.

- The hot cells are kept under negative pressure relative to the interior of the building. The building itself is not sealed.

- A building space diagram is attached to this form showing the locations of the various process areas and equipment.

Release Information

Description of release, or threatened release, and source:

Information concerning the extent of radiological contamination in Building 3026-D was found to be limited in availability during this RmSE. Information provided in the Hazard Screening Report prepared for the facility is not as detailed as that of other buildings evaluated, but does indicate the presence of radiologic contamination. Based on past practices and process in this facility and comparison with the condition of other Isotopes facilities, it can be assumed with some certainty that residual radiologic surface contamination exists in hot cells and process equipment (vessels, hoods, piping, ventilation ducts, etc.). This contamination would have accumulated from activities involving a variety of materials throughout the operating history of the facility and, therefore, cannot be attributed to a single release episode. Approximately $150 \mathrm{Ci}$ $(4,000 \mathrm{lbs})$ of ${ }^{60} \mathrm{Co}$ remains in the Storage Cell within the building. Storage of this material is considered a potential radiologic release source. The total existing levels of RAD contamination in the facility are unknown based on available information. However, the presence of this contamination is not considered a significant hazard in its current state.

Hazardous materials (HAZMATs) (e.g., acids, hydraulic fluids, and other chemicals) were reportedly used in small quantities (i.e., less than 5 gallons or 100 pounds) during facility operations and currently for surveillance and maintenance (S\&M) activities. Additionally, zinc-bromide remains present in the cell viewing windows. This fluid is leaking from some windows of Cell $\mathrm{A}$. The leaks are contained by collecting the leaking fluid in a drum or bucket and pumping it back into the window. While this does not stop the leak, it does provide interim control preventing the fluid from migration until either the windows are repaired or the fluid is removed. However, this presents a potential release source in that any fluid spilled or not captured in the collections drums could find its way to an active floor drain in the Operating Area adjacent to the east cell bank and migrate away from the building. The Operating Area was inaccessible during the facility inspection, and no drain location information was available for Building 3026-D at the time of this report; therefore, it is not known whether a floor drain is located in close proximity to the leaking windows. The potential for significant release of zinc-bromide is considered slight in this case. No other conditions were identified which present a potential for a significant HAZMAT release.

\section{Hazardous substances present:}

Hazardous substances remaining in Building 3026-D consist mainly of residual RAD surface contamination $(\alpha, \beta, \gamma)$, irradiated metal specimens, zinc-bromide, PCBs, and a small quantity of miscellaneous HAZMATs. Areas of fixed and transferable RAD contamination are associated primarily with the hot cells, storage cell, and process equipment. Zinc-bromide remains present in the hot cell viewing windows. PCBs are present in cell lighting ballasts within the building. Hazardous materials present in the building are listed on the attached HAZMAT inventory sheet. 
Estimate (if possible) of quantities of hazardous substances that have been released and that could be released:

The following represents the known quantities of substances currently existing in the facility. Radiologic surface contamination has accumulated from a legacy of many different programs and processes and cannot be attributed to a single release episode. It is only possible to quantify release amounts from contamination which currently exists in the facility and/or has been historically documented from past activities.

$\approx 150 \mathrm{Ci}^{60} \mathrm{Co}$.

$\approx 2,000$ gallons zinc-bromide.

$<5$ gallons PCBs. Quantity estimated based on visual inspection (information on exact quantity was not available at the time of this report.)

$\approx 139$ pounds total miscellaneous HAZMATs (see attached HAZMAT inventory sheet).

(Quantity estimates obtained from Building 3026-D Hazard Screening Report, Visual Inspection of PCB Containing Equipment, ORNL Hazardous Material Information System Database.)

\section{Other pollutants or contaminants:}

Asbestos containing material, primarily in the form of thermal system insulation, has been confirmed present in this building. ACM observed is in fair to good condition and poses no immediate health threat. Based on the age of the facility, interior and exterior painted surfaces are assumed to be lead-containing. Verification samples are taken by ORNL Lead Management Program personnel on an "as-needed" basis to confirm the presence of lead in the paint (i.e., when work activities will disturb the paint, or paint is found to be deteriorating and poses a health or environmental threat). Interior painted surfaces observed are in fair to good condition and pose no immediate health threat. Paint on exterior wood surfaces (particularly the north side of the building) and exterior cell ventilation duct work is chipped and flaking off to the ground below in some areas. According to the ORNL Lead Management Office, no verification samples on this paint have been taken and analyzed; therefore, the area remains assumed to contain lead.

\section{Groundwater}

Are there any suspected impacts to groundwater? If yes, please describe. Include any impacts to drinking water sources.

Building 3026-D is located in Waste Area Grouping 1 at ORNL. Although no specific adverse spills or releases of hazardous substances were identified during this RmSE, it is suspected, based on available environmental studies conducted in WAG 1, that process and LLLW drains and associated piping may have leaked over the life of the facility. Buried process and LLLW piping and some drains have been found to be deteriorated and leaking in other facilities and areas of WAG 1 . Studies have determined that groundwater in WAG 1 has been both radiologically and chemically contaminated. Numerous man-made radionuclides have been detected in WAG 1 groundwater samples including many of those processed in Building 3026-D. It is likely that liquid waste from activities involving radioisotopes in Building 3026-D have historically contributed to WAG 1 groundwater contamination. However, the radionuclides detected in the groundwater were common to the processes and activities in many other buildings in the area which makes it difficult to determine exactly which building is, or was, the source of contamination. 
Are there any suspected impacts to groundwater? If yes, please describe. Include any impacts to drinking water sources (Continued).

Because of the reported small quantities of chemicals historically used in this facility, it is unlikely that such usage has significantly contributed to WAG 1 groundwater contamination. As part of the facility shutdown process, inactive process and LLLW drains within the building have reportedly been plugged to prevent further release. However, no documentation was available at the time of this report to verify which drains have actually been plugged and which have not. Additionally, no information was available to determine drain locations within the facility. Cell and hot sink drains reportedly discharge to Tank W-16 of the LLLW system.

Although it is not impossible, it is unlikely that groundwater has been, or will be, impacted by the flaking and chipping exterior paint located on the north side of the building if, in fact, it is lead-containing. Because of the depth to the water table in the area of Building 3026-D $(\approx 20$ feet $)$ and physical characteristics of soil in the area, it is doubtful that any significant amount of lead has, or will, reach the groundwater through percolation with storm water and vertical migration.

Other than the potential for historical impact to groundwater in WAG I via leaking process and LLLW lines external to the building, no existing immediate threat to groundwater was identified given the current status of the facility.

\section{Surface Water}

Are there any suspected impacts to surface water? If yes, please describe. Also describe the most likely surface water migration route(s), if applicable. Include any impacts to drinking water sources.

WAG 1 is essentially bound by Fifth Creek to the east, White Oak Creek (WOC) to the south, and First Creek to the west. First and Fifth creeks flow south into (WOC) which flows to the west and exits WAG 1 at the southwest corner. Storm water (from surface runoff and storm water drainage system) and treated water from the process waste system discharges into WOC. The only potential for direct impact to surface water from Building 3026-D in its current state would be from lead-containing paint chips which fall off the first and second story exterior painted surfaces and find their way into the storm water drainage system and eventually to WOC. The apron around the north side of the building is gravel and grass below the areas of deteriorating paint. Peeling paint from the second story of the building in this area could fall off onto the first story roof and could get washed off the roof through the roof drains with storm water. The roof drain in this area spills to the surface of the north-central portion of the building apron. This area of the apron is a restricted area and was not accessible during the building inspection. No storm drains were observed in this area from a distance; however, if a storm drain exists, there is a potential that paint chips could migrate to WOC through the storm water drainage system.

Surface water may have also been indirectly impacted by leaking process and LLLW lines external to the building. Some of these lines are known to have shared a common trench with storm water drainage piping. Contamination from leaking waste lines could potentially enter storm water piping and migrate to WOC. The three creeks bordering WAG 1 are groundwater discharge points. Therefore, groundwater contaminated by leaking waste lines could also potentially impact surface water in the area.

Other than the potential for historical impact, the only existing immediate threat to surface water identified during this RmSE is that from the assumed lead-containing paint at the north of the building. 
Air

Are there any suspected impacts due to air emissions? If yes, please describe.

It can be reasonably assumed, based on information provided in the Hazard Screening Report prepared for Building 3026-D that a slight potential for radiation exposure to personnel working inside and within the immediate vicinity of the facility exists due to potential airborne migration of radioactive particulates and physical contact with contaminated surfaces. Areas of RAD contamination are identified, marked, and controlled as appropriate throughout the facility to protect against inadvertent exposure to personnel. Air flow in the building is controlled by the design of the ventilation system which moves air from areas with a low potential for contamination through areas with a higher potential for contamination and exhausts the air through the Isotopes Circle cell ventilation system to stack 3039. Apart from catastrophic failure of the hot cells or cell ventilation system, it is unlikely that radioactive air emissions from Building 3026-D would impact personnel or the environment in its current state.

There is also a potential for impact to indoor air quality due to the presence of ACM and assumed lead-based paint (LBP) should these materials be disturbed. The ACM and assumed LBP remaining in the building are not considered to be immediate threats to indoor quality in their current state.

\section{Soil}

Are there any suspected impacts to soil? If yes, please describe.

The only existing immediate threat to soils identified in the area of Building 3026-D is located adjacent to the north side of the facility. Paint on the exterior of the north wall is badly deteriorated and is peeling off the building. Paint on the cell ventilation system duct work in this area also shows evidence of localized deterioration. This paint is assumed to contain lead by the ORNL Lead Management Office. The soil in this area is at risk of being impacted by lead contamination from paint that has peeled or chipped off the wall or duct work if, in fact, the paint does contain lead.

As stated for groundwater, there is also a potential for historical impact to soils in the area of Building 3026-D due to leaking process and LLLW drain piping. Previous environmental studies have identified a soil contamination plume in the Isotopes Circle area and soil samples collected from the plume have detected radioisotopes common to the processes performed in Building 3026-D. Whether waste from Building 3026-D has actually contributed to this contamination is unknown, given the information reviewed during this RmSE. It is unlikely that the small quantities of chemicals used in Building 3026-D have significantly impacted soil in the surrounding area.

\section{Release Beyond Facility or Reservation Boundaries}

Has or will the release migrate beyond the boundaries of the facility or reservation? If yes, please describe (including possible human or environmental receptors).

The following are considered potential scenarios where radiologic contamination could migrate beyond the facility or reservation boundaries:

- A person becomes inadvertently contaminated and leaves the facility/reservation undetected.

- Catastrophic failure of hot cells and/or contaminated equipment. 
Has or will the release migrate beyond the boundaries of the facility or reservation? If yes, please describe (including possible human or environmental receptors). (Continued)

A potential also exists for assumed lead-containing paint which peels off the north side of the building to be carried away with surface runoff during a rain event. Additionally, a potential exists for zinc-bromide to migrate away from the facility if a floor drain is located in close proximity to leaking hot cell windows. Though these potentials exist, they are considered slight and unlikely due to the current status of the facility and the engineering/administrative controls that are in place to protect again such an event.

\section{Worker Safety}

Could the release pose a threat to workers? If yes, please describe.

Radiologically contaminated areas are isolated and well marked. Good radiation practices and standard operating procedures are enforced for worker safety. Personnel exiting the facility are required to "frisk" themselves to detect the presence of RAD contamination. Monitors and alarms are in place to detect any radioactive release within the building. PCB containing equipment and ACM are appropriately labeled. However, even with these safeguards in place, a potential threat to workers exists if safety measures are overlooked. This potential is not considered significant given the current status and level of activity of the building.

\section{Environmental Receptors}

Does the release pose a potential threat to environmental receptors? If yes, please describe. Include natural resources impacts.

No existing conditions posing an immediate significant threat to environmental receptors, including natural resources, were identified to be currently associated with Building 3026-D.

\section{Mitigation}

What action(s) might be taken to abate/prevent release or impacts from release?

- Continued utilization and enforcement of engineering and administrative controls that are currently in place to protect workers and monitor conditions and activities in the building.

- Exterior paint on the north wall of the facility and on cell ventilation system duct work in the area should be tested for lead content. If the paint is found to be lead-containing, a maintenance action will be required to eliminate areas of deteriorating paint. In addition, a remedial site evaluation will be necessary to determine whether the soil in this area has been impacted by lead from the peeling paint.

- Continue S\&M activities per Procedure IP-900. 
What actions are currently being taken to abate/prevent release or impacts from release?

Engineering and administrative controls are in place to control access to contaminated areas and to monitor conditions and activities within the facility for worker and environmental protection. Warning signs and labels are posted throughout the facility indicating RAD, ACM, and PCB hazard areas. Standard operating procedures are in place for building access and surveillance and maintenance activities to protect against inadvertent contact and disturbance of contaminated areas and materials. Zinc-bromide from leaking cell windows is collected and pumped back into the window. Radiologically contaminated areas are monitored periodically by ORNL health physics personnel. Personnel are "frisked" upon exit of the facility to detect the presence of radiologic contamination. The building is currently in surveillance and maintenance status awaiting entry into the Decontamination and Decommissioning (D\&D) Program. Inactive waste drains are reportedly plugged in contaminated areas to prevent inadvertent discharge of contamination beyond the facility. A groundwater monitoring program is in place to monitor contamination levels and migration in groundwater underlying WAG 1 . The building is inspected for structural changes after each natural incident (earthquake, tornado, or other severe storm), fire and/or man induced activity which could cause cracking, failure, or deterioration of the facility and/or equipment that may allow contamination to be released. No such conditions have been reported for Building 3026-D.

With the exception of the deteriorating areas of exterior paint, current actions being taken to prevent further release and ensure worker safety in Building 3026-D are considered adequate until D\&D activities begin.

\begin{tabular}{l}
\hline \multicolumn{1}{|c|}{ Other Environmental Authorities } \\
\hline $\begin{array}{l}\text { Is the release or threatened release potentially subject to other environmental statutory actions? If yes, } \\
\text { please explain. }\end{array}$
\end{tabular}

If paint is found to be lead-containing and samples fail the Toxicity Characteristic Leaching Procedure (TCLP) analysis, the building could qualify as a hazardous waste generator point under the Resource Conservation and Recovery Act (RCRA).

\section{Maintenance Actions}

Are maintenance actions necessary to eliminate potential threats to human health and the environment? If so, explain.

Samples should be taken of the exterior paint located on the north wall of the facility and adjacent cell ventilation duct work. The samples should then be analyzed to determine whether the paint does, in fact, contain lead. Such analysis should include TCLP (40 CFR 261, Appendix II) to determine whether Building 3026-D qualifies as a RCRA generator point. If the paint is found to contain lead, abatement actions will be required to prevent deteriorated areas of paint from dislodging and falling to the ground below, potentially having a direct impact on soil in this area.

Although the leaking zinc-bromide windows do not present an immediate threat, it is recommended that either the leaking windows be repaired and the leaks stopped or that the fluid be drained and disposed of, if it is no longer needed. This will reduce/eliminate the potential for an inadvertent HAZMAT release within the facility.

No further potential hazards requiring maintenance actions were identified to be associated with Building 3026-D. 
\begin{tabular}{l} 
Removal Actions \\
\hline $\begin{array}{l}\text { Are Removal Actions necessary to eliminate immediate threats to human health and the environment? If } \\
\text { so, explain. }\end{array}$
\end{tabular}

No imminent hazards requiring removal actions per 40 CFR 300.415 were identified to be currently associated with Building 3026-D.

\section{Remedial Site Evaluation}

Is a Remedial Site Evaluation needed?

Pending confirmatory sampling and analysis results of the exterior paint in the north area of the facility, a remedial site evaluation (RSE) should be conducted to determine whether the soil in this area has been impacted by lead from chipping paint and whether remediation of the soil is necessary.

Areas of radiologic contamination associated with Building 3026-D have been identified and marked as appropriate. However, it is suspected that process and LLLW drains and associated piping may have leaked beneath the slab of the building as a result of past practices. As a result, it is recommended that some type of remedial investigation be performed to assess the condition of the soil in this area before conducting any $S \& M$ or $D \& D$ activities which involve disturbing the slab.

ACM and PCB-containing equipment have also been identified, marked and documented. No further remedial investigation involving these hazards is considered necessary given the current status and future plans of this facility.

Based on the age of the facility, painted surfaces are assumed to contain lead. Samples of the paint should be taken and analyzed to verify the presence of lead prior to conducting any S\&M or D\&D activities which may disturb these assumed areas.

\section{No Further Investigation}

Is a finding of No Further Investigation appropriate? Please explain.

A finding of No Further Investigation implies that a facility or area is free from hazardous substances or contaminants that may threaten human health and the environment. Since Building 3026-D contains substances and materials which may become threatening if not properly controlled, handled and managed during the S\&M cycle, a finding of No Further Investigation is inappropriate in this case. 


\section{Additional Comments}

The following documents and databases were referenced for historical and hazard information related to Building 3026-D:

- Hazard Screening, Segmenting Hot Cell Facility, Building 3026-D, Document No. HS/3026D/F/92/R0.

- Work Plan for the Isotopes Facilities Deactivation Project at Oak Ridge National Laboratory, Document No. ORNL/ER-249/R2.

- Building 3026-D Occurrence Reports, 1989 to present.

- Site Characterization Summary Report for Waste Area Grouping 1 at Oak Ridge National Laboratory, Oak Ridge, Tennessee, Volumes 1 and 2, Document Nos. DOE/OR-1043/V1\&D1 and DOE/OR-1043/V2\&D1.

- ORNL Hazardous Material Information System Database.

The following personnel and offices were contacted and provided historical and current use/condition information for Building 3026-D:

- Mr. Karl Haff, Radiochemical Processing Department Head, ORNL Radiochemical Technology Section.

- Ms. Swati Wilson, Manager, ORNL Lead Management Program.

- Mr. Nathan Dunn, Hazardous Material Information System Office.

- Mr. Jade Thomas, ORNL Environmental Compliance Office.

- Mr. Joe Armento, ORNL Chemical Technology Division, Isotopes Facilities Shutdown Program.

The RmSE of this facility was conducted for LMES under contract by:

Advanced Sciences, Inc.

800 Oak Ridge Turnpike, Suite C-102

Oak Ridge, TN

Todel. lonent

Evaluator's Signature

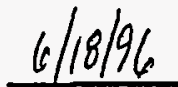

Date 


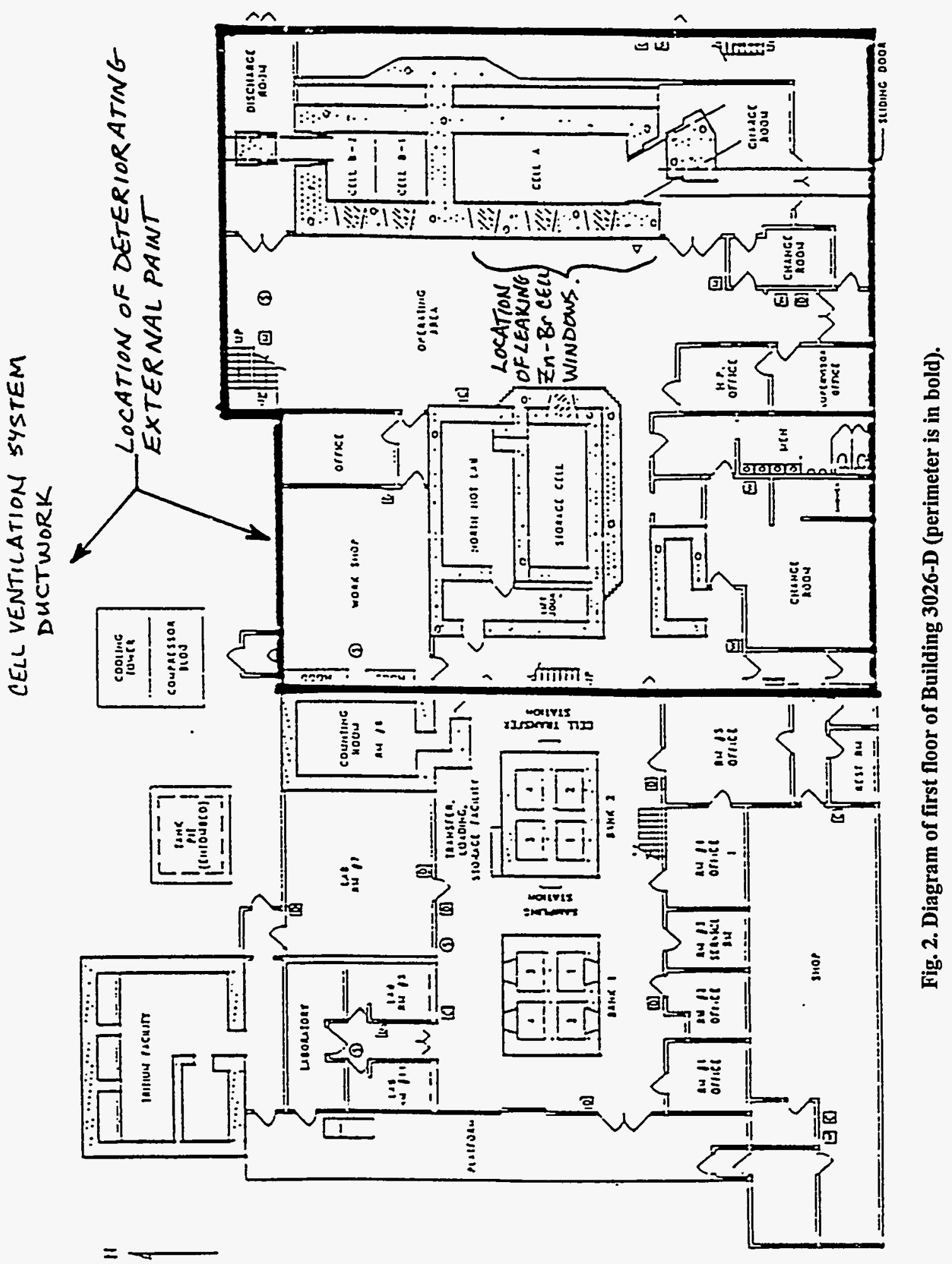




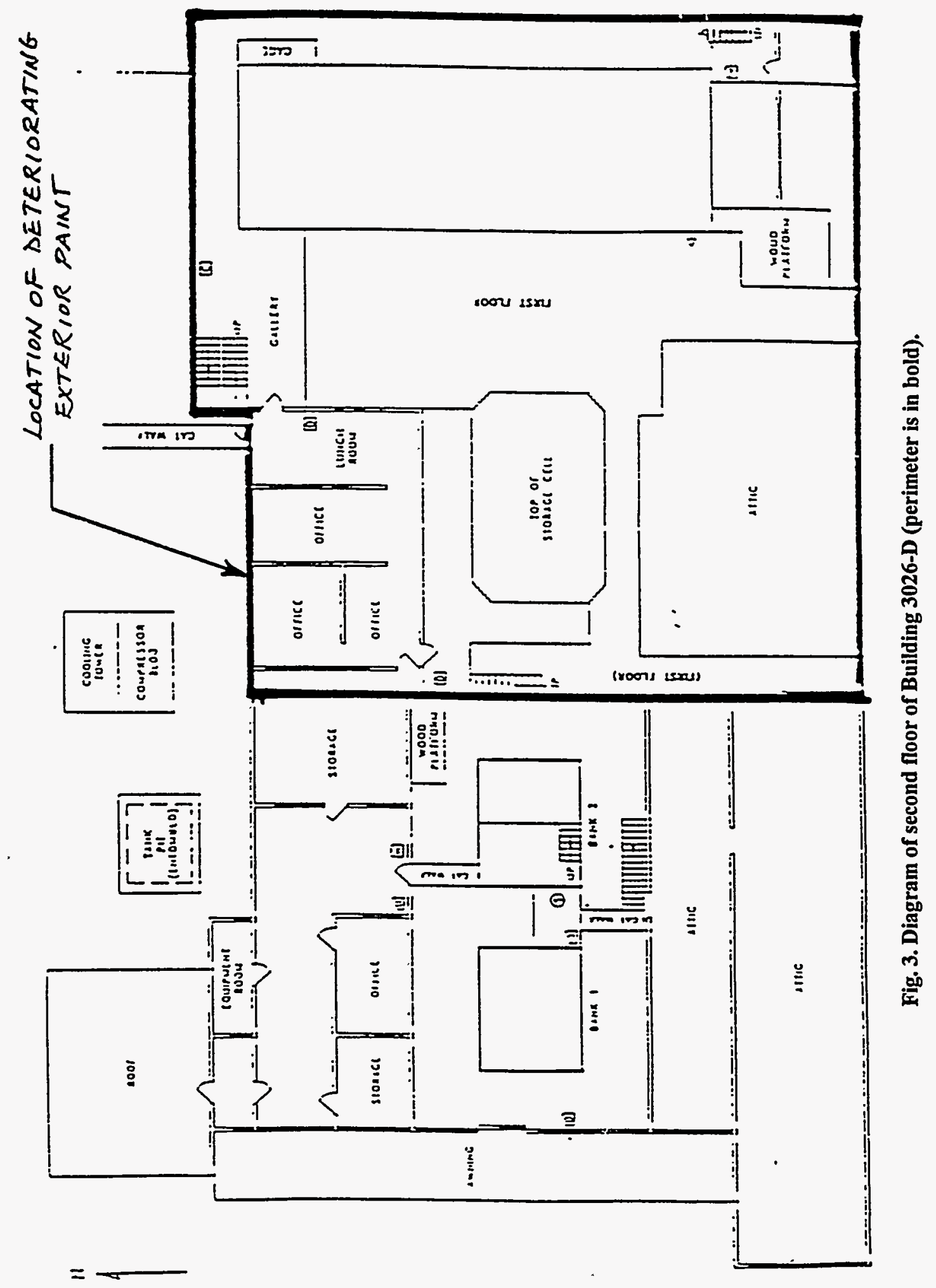


4-14

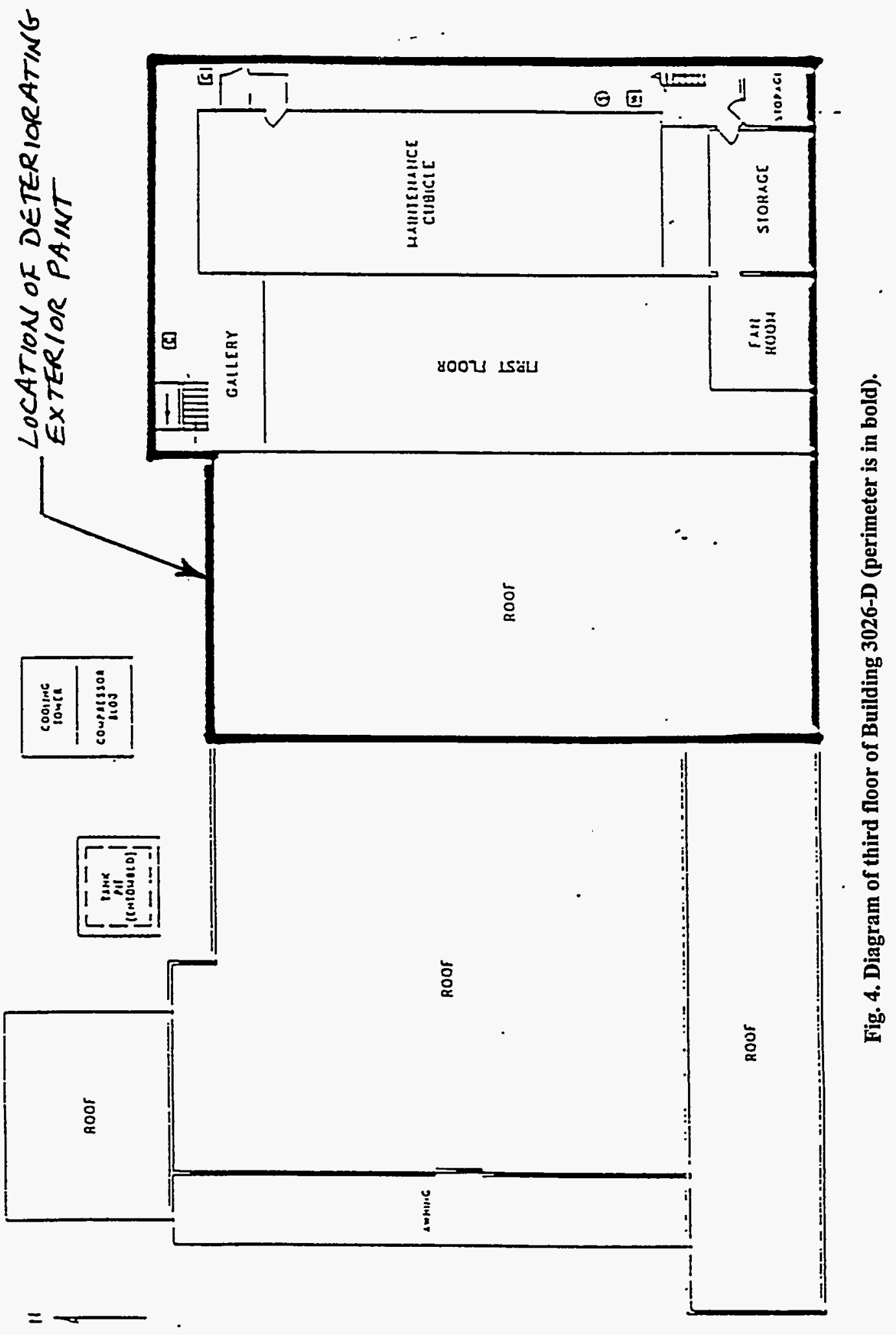




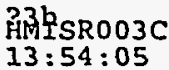

Plant: 3 Division:

Date Expixation:

Building: $3026 \mathrm{D}$

\begin{tabular}{lll} 
RECID ** & CASNO \\
\hline 04624 & - & $007727-37-9$ \\
89735 & NISS
\end{tabular}

03-28-1996

MS MATERIALS INFORMATION SYSTEM Management Inventory Summary Report (by Building)

Department :

Control Area : Mix Comp:

Room:

Inv status: MSDS Avail: Maz Mat Grp Cd: ${ }^{2}$ Phy State: Pressure Cd: Temp Cd: Cont Type Cd:

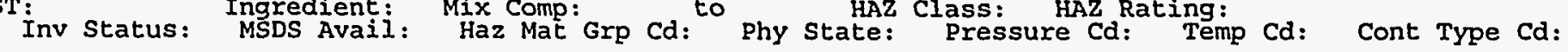

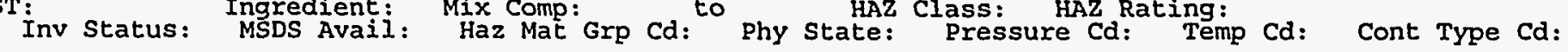

UNCLAASSIFIED Page:
Installation: ORNL

WA Code:

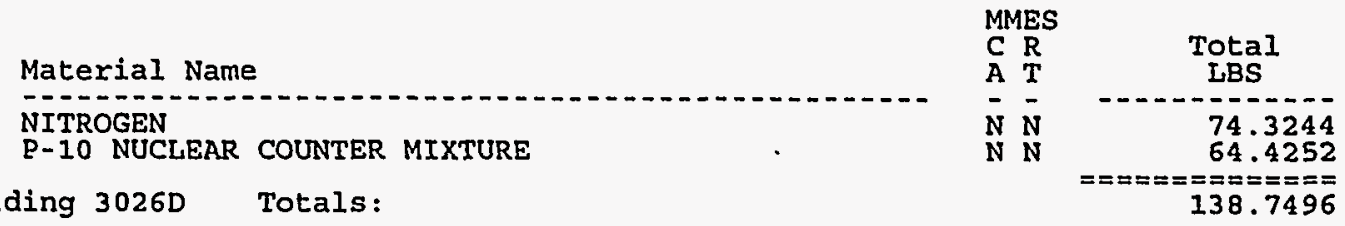

Total
KILOGRAMS
33.7132
29.2228
62.9360

No of

Building 3026D Totals: 


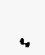

. 
5. BUILDING 3028-ALPHA POWDER FACILITY 


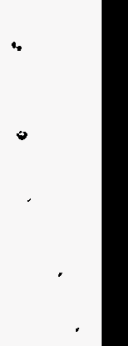

, 


\section{ORNL FACILITY RmSE INFORMATION FORM}

\begin{tabular}{|c|c|}
\hline \multicolumn{2}{|c|}{ General Information } \\
\hline $\begin{array}{l}\text { Building } 3028 \\
\text { Radioisotope Laboratory A }\end{array}$ & a Powder Facility) \\
\hline $\begin{array}{l}\text { Organization responsible for arealfacility } \\
\text { (include specific person and phone number if possible): }\end{array}$ & $\begin{array}{l}\text { R.E. Eversole (576-7483), } \\
\text { IFDP Project Manager, } \\
\text { ER Program, LMES }\end{array}$ \\
\hline Status (active/inactive): $\quad$ Inactive, Standby Mode & Years of Operation: $\approx 38$ \\
\hline $\begin{array}{l}\text { Description of Operation: } \\
\text { There are no current operations, other than surveillance, } \\
\text { in this building. Building } 3028 \text { was originally constru } \\
\text { fission products from uranium-aluminum targets. The } \\
\text { processing cells. It has been used for storage, proces } \\
\text { isotopes. Building } 3028 \text { originally housed the }{ }^{131} \mathrm{I} \text { proce } \\
\text { Operating Area) and the separation facility (a four-story } \\
\text { was converted to manipulator cells in the early } 1960 \mathrm{~s} \text { a } \\
\text { Facility. The }{ }^{133} \mathrm{Xe} \text { facility was added at about the same } \\
\text { included }{ }^{133} \mathrm{Xe},{ }^{131} \mathrm{I} \text {, and }{ }^{99} \mathrm{Mo} \text {. }{ }^{133} \mathrm{Xe} \text { operations contir } \\
\text { Product Program was discontinued in } 1985 \text {. Radioisotope } \\
\text { in contained hot cells and lob hoods. Resulting prim } \\
\text { exhausted air and liquid process waste. }\end{array}$ & $\begin{array}{l}\text { tenance, and deactivation activities, on-going } \\
\text { to separate }{ }^{131} \mathrm{I} \text {, }{ }^{133} \mathrm{Xe} \text {, and other short-lived } \\
\text { lding was later expanded to include curium } \\
\text { conversion, and dispensing of radioactive } \\
\text { exchange column) for }{ }^{147} \mathrm{Pm} \text {. The The Product } \\
\text { expanded to the Short-Lived Fission Product } \\
\text { e. Products and processes developed for sale } \\
\text { through } 1980 \text {, and the Short-Lived Fission } \\
\text { essing and handling was performed primarily } \\
\text { waste streams for these processes included }\end{array}$ \\
\hline $\begin{array}{l}\text { Physical description of arealfacility: } \\
\text { - } \quad \text { Building } 3028 \text { was originally constructed in } 1950 \text {. } \\
\text { The facility is a steel frame structure with metal sidi } \\
\text { single-story operating areas on east and west end of b } \\
\text { Exterior surfaces of building have been covered wit } \\
\text { purposes. } \\
\text { During operations, the building was kept under nega } \\
\text { and only contaminated hot cells remain under negativ } \\
\text { Exterior of building is generally clean and in good } \\
\text { damage or determination. } \\
\text { - Equipment has been removed from story } 2,3 \text {, and } 4 \text { a } \\
\text { The interior portions of the first three stories are in } \\
\text { condition. Painted surfaces throughout the facility are } \\
\text { (particularly the } 4 \text { th floor). Asbestos Containing M } \\
\text { are posted and/or labeled as appropriate. } \\
\text { Access to the Alpha Powder Cell on the } 1 \text { st floor is re } \\
\text { Building } 3028 \text { is located in Isotopes Circle, an } \\
\text { surrounding the facility is paved. Building utilities in }\end{array}$ & $\begin{array}{l}\text { consisting of a four-story central section with } \\
\text { ing. } \\
\text { lyurethane foam sealant for containment } \\
\text { pressure. Currently, building is inactive } \\
\text { essure relative to the building interior. } \\
\text { dition with no visible areas of significant } \\
\text { hese areas are currently empty. } \\
\text { o good condition. The fourth story is in poor } \\
\text { cking, flaking, and chipping in some locations } \\
\text { al (ACM), and radiation (RAD) hazard areas } \\
\text { cted due to contamination. } \\
\text { strial area of ORNL. The immediate area } \\
\text { e steam, plant air and electrical service. }\end{array}$ \\
\hline
\end{tabular}


Physical description of area/facility: (Continued)

- The building contains primarily laboratories, hot cells, and process areas. There are seven hot cells located on the first floor of the building. The viewing windows of the hot cells are filled with water or mineral oil. Floor drains in Cells 1-4 discharge to an intermediate holding tank (W11) before discharging to the low-level liquid waste (LLLW) system (Tank WC-10). Cells 5-6 drain directly to the LLLW system (Tank WC-10). Cell 7 contains one drain which discharges to Tank WC-2 and two drains which discharge to Tank WC-10 of the LLLW system.

- Cell 7 has been decontaminated and cleaned.

- Work with radioactive material was performed primarily in the hot cells, hoods, and laboratory areas within this facility.

- A building space diagram is attached to this form showing the locations of the various process areas and equipment.

\section{Release Information}

Description of release, or threatened release, and source:

Low levels of residual fixed radiologic surface contamination exists in areas of the facility as a result of historical operations. The contamination exists primarily in the hot cells and process equipment (vessels, hoods, piping, ventilation ducts, etc.). This contamination has accumulated from activities involving a variety of materials throughout the operating history of the facility and, therefore, cannot be attributed to a single release episode. The existing levels of $\mathrm{RAD}$ contamination in the facility are low and the presence of this contamination is not considered a significant hazard in its current state.

Hazardous materials (HAZMATs) (e.g., acids, hydraulic fluids, and other chemicals) were reportedly used in small quantities (i.e., less than 5 gallons or 100 pounds) during facility operations and currently for surveillance and maintenance (S\&M) activities. According to available spill/release records and facility personnel interviews, no significant HAZMAT spills (i.e., spills having the potential to adversely affect human health and/or the environment) have been reported for this building. No current conditions were identified which present a potential for a significant HAZMAT release.

\section{Hazardous substances present:}

Bulk HAZMATs have been removed from Building 3028. Hazardous substances remaining consist mainly of residual radiologic surface contaminants $(\alpha, \beta, \gamma)$. Fixed radiologic contamination exists in localized areas throughout the facility. Some of these areas have been painted over to contain $\alpha$ contamination. Highest levels of radiologic contamination exist in hot cells 1-6 which are isolated and kept under negative pressure. Hot cell 7 has been decontaminated to allow personnel access.

No items containing PCBs were identified to present within this building.

Estimate (if possible) of quantities of hazardous substances that have been released and that could be released:

The following represents the known quantities of substances currently existing in the facility. Radiologic surface contamination has accumulated from a legacy of many different programs and processes and cannot be attributed to a single release episode. It is only possible to quantify release amounts from contamination which currently exists in the facility and/or has been historically documented from past activities.

$\approx 10 \mu \mathrm{Ci} \alpha$ contamination in facility, $\approx 150 \mathrm{mCi} \alpha$ in hot cells

$\approx 25 \mu \mathrm{Ci} \beta / \gamma$ contamination in facility, $\approx .45 \mathrm{Ci} \beta / \gamma$ in hot cells

(Quantity estimates obtained from Building 3028 Hazard Screening Report) 
Other pollutants or contaminants:

Asbestos containing material, primarily in the form of thermal system insulation, has been confirmed present in this building. ACM observed is in fair to good condition and poses no immediate health threat. Based on the age of the facility, interior and exterior painted surfaces are assumed to be lead-containing. Verification samples are taken by ORNL Lead Management Program personnel on an "as-needed" basis to confirm the presence of lead in the paint (i.e., when work activities will disturb the paint, or paint is found to be deteriorating and poses a health or environmental threat). Interior painted surfaces observed are in fair to good condition on the first three floors and poor condition on the fourth floor. These areas pose no immediate health threat given the status of this facility.

\section{Groundwater}

Are there any suspected impacts to groundwater? If yes, please describe. Include any impacts to drinking water sources.

Building 3028 is located in Waste Area Grouping 1 at ORNL. Although no specific adverse spills or releases of hazardous substances threatening the groundwater were identified during this RmSE, it is suspected, based on available environmental studies conducted in WAG 1, that process and LLLW drains and associated piping may have leaked over the life of the facility. Buried process and LLLW piping and some drains have been found to be deteriorated and leaking in other facilities and areas of WAG 1. Studies have determined that groundwater in WAG 1 has been both radiologically and chemically contaminated. Numerous man-made radionuclides have been detected in WAG 1 groundwater samples including many of those processed in Building 3028. It is likely that liquid waste from activities involving radioisotopes in Building 3028 have historically contributed to WAG 1 groundwater contamination. However, the radionuclides detected in the groundwater were common to the processes and activities in many other buildings in the area which makes it difficult to determine exactly which building is, or was, the source of contamination.

Because of the reported small quantities of chemicals historically used in this facility, it is unlikely that such usage has significantly contributed to WAG 1 groundwater contamination. As part of the facility shutdown process, inactive process and LLLW drains within the building have reportedly been plugged to prevent further release. However, no documentation was available at the time of this report to verify which drains have actually been plugged and which have not. Information on drain locations and discharge points is available from the ORNL Engineering Support Office.

Other than the potential for historical impact to groundwater in WAG 1 via leaking process and LLLW lines external to the building, no existing immediate threat to groundwater was identified given the current status of the facility. 


\section{Surface Water}

Are there any suspected impacts to surface water? If yes, please describe. Also describe the most likely surface water migration route(s), if applicable. Include any impacts to drinking water sources.

WAG 1 is essentially bound by Fifth Creek to the east, White Oak Creek (WOC) to the south, and First Creek to the west. First and Fifth creeks flow south into (WOC) which flows to the west and exits WAG 1 at the southwest comer. Storm water (from surface runoff and storm water drainage system) and treated water from the process waste system discharges into WOC. The only potential for direct impact to surface water from Building 3028 in its current state would be from lead-containing paint chips which fall off the exterior painted surfaces and find their way into the storm water drainage system and eventually to WOC.

Based on the age of this facility, it is assumed that painted surfaces contain lead. The exterior paint of Building 3028 is in good condition and there was no visible evidence of significant deterioration observed during the site inspection. Therefore, the potential for impact to surface water due to assumed exterior lead-based paint is considered slight.

Surface water may have also been indirectly impacted by leaking process and LLLW lines external to the building. Some of these lines are known to have shared a common trench with storm water drainage piping. Contamination from leaking waste lines could potentially enter deteriorated storm water piping and migrate to WOC. The three creeks bordering WAG 1 are groundwater discharge points. Therefore, groundwater contaminated by leaking waste lines could also potentially impact surface water in the area.

Air

Are there any suspected impacts due to air emissions? If yes, please describe.

The Hazard Screening Report prepared for Building 3028 indicates a slight potential for radiation exposure to personnel working inside and within the immediate vicinity of the facility exists due to potential airborne migration of radioactive particulates and physical contact with contaminated surfaces. Areas of RAD contamination are identified, marked, and controlled as appropriate throughout the facility to protect against inadvertent exposure to personnel. Hot cells in the building are kept under negative pressure; however, the building is no longer operated under negative pressure. The Alpha Cells (Cell 1-4) exhaust through high efficiency particulate air (HEPA) filters to the process off-gas system and stack 3039. Cells 5-7 exhaust through HEPA filters to the cell ventilation system and stack 3039. Apart from catastrophic failure of the hot cells or cell ventilation system, it is unlikely that radioactive air emissions from Building 3028 would impact personnel or the environment in its current state.

There is also a potential for impact to indoor air quality due to the presence of ACM and assumed lead-based paint (LBP) should these materials be disturbed. The ACM and assumed LBP remaining in the building are not considered to be immediate threats to indoor quality in their current state. 


\section{Soil}

Are there any suspected impacts to soil? If yes, please describe.

As stated for groundwater, there is also a potential for historical impact to soils in the area of Building 3028

due to leaking process and LLLW drain piping. Previous environmental studies have identified a soil contamination plume in the Isotopes Circle area and soil samples collected from the plume have detected radioisotopes common to the processes performed in Building 3028 .

The WAG 1 Site Characterization Report and interviews with facility personnel indicated that a LLLW drain line was found to be leaking adjacent to Building 3028 in the early 1980's. The leak contaminated the soil in the immediate area. The soil was reportedly remediated and the leak was repaired. As a result of this spill, it is likely that past activities in Building $\mathbf{3 0 2 8}$ have contributed to the isotopes area soil contamination plume.

It is unlikely, however, that the small quantities of chemicals used in Building 3028 have significantly impacted soil in the surrounding area.

\section{Release Beyond Facility or Reservation Boundaries}

Has or will the release migrate beyond the boundaries of the facility or reservation? If yes, please describe (including possible human or environmental receptors).

The following are considered potential scenarios where radiologic contamination could migrate beyond the facility or reservation boundaries:

- A person becomes inadvertently contaminated and leaves the facility/reservation undetected.

- Catastrophic failure of hot cells and/or contaminated equipment.

There is also a potential for assumed lead-containing paint which peels off of the building to be carried away with surface runoff during a rain event. Though these potentials exist, they are considered slight and unlikely due to the current status of the facility and the engineering/administrative controls that are in place to protect again such an event.

\section{Worker Safety}

Could the release pose a threat to workers? If yes, please describe.

Radiologically contaminated areas are isolated and well marked. Good radiation practices and standard operating procedures are enforced for worker safety. Personnel exiting the facility are required to "frisk" themselves to detect the presence of RAD contamination. Monitors and alarms are in place to detect any radioactive release within the building. Asbestos containing material is appropriately labeled. However, even with these safeguards in place, a potential threat to workers exists if safety measures are overlooked. This potential is not considered significant given the current status and level of activity of the building.

\section{Environmental Receptors}

Does the release pose a potential threat to environmental receptors? If yes, please describe. Include natural resources impacts.

No significant immediate threat to environmental receptors within the area surrounding Building 3028, including natural resources, was identified to exist as a result of contamination and conditions currently present in the facility. 


\section{Mitigation}

What action(s) might be taken to abate/prevent release or impacts from release?

- Continued utilization and enforcement of engineering and administrative controls that are currently in place to protect workers and monitor conditions and activities in the building.

- Continue S\&M activities per Procedure IP-900.

What actions are currently being taken to abate/prevent release or impacts from release?

Engineering and administrative controls are in place to control access to contaminated areas and to monitor conditions and activities within the facility for worker and environmental protection. Warning signs and labels are posted throughout the facility indicating RAD, and ACM hazard areas. Standard operating procedures are in place for building access and surveillance and maintenance activities to protect against inadvertent contact and disturbance of contaminated areas and materials. Radiologically contaminated areas are monitored periodically by ORNL health physics personnel. Personnel are "frisked" upon exit of the facility to detect the presence of radiologic contamination. The building is currently in surveillance and maintenance status awaiting entry into the Decontamination and Decommissioning (D\&D) Program. Inactive waste drains are reportedly plugged in contaminated areas to prevent inadvertent discharge of contamination beyond the facility. A groundwater monitoring program is in place to monitor contamination levels and migration in groundwater underlying WAG 1 . The building is inspected for structural changes after each natural incident (earthquake, tornado, or other severe storm), fire and/or man induced activity which could cause cracking, failure, or deterioration of the facility and/or equipment that may allow contamination to be released. No such conditions have been reported for Building 3028 .

Current actions being taken to prevent further release and ensure worker safety in Building 3028 are considered adequate until D\&D activities begin.

Other Environmental Authorities

Is the release or threatened release potentially subject to other environmental statutory actions? If yes, please explain.

If paint is found to be lead-containing and samples fail the Toxicity Characteristic Leaching Procedure (TCLP) analysis, the building could qualify as a hazardous waste generator point under the Resource Conservation and Recovery Act (RCRA).

Maintenance Actions

Are maintenance actions necessary to eliminate potential threats to human health and the environment? If so, explain.

No potential hazards requiring maintenance actions were identified to be associated with Building 3028 .

Removal Actions

Are Removal Actions necessary to eliminate immediate threats to human health and the environment? If so, explain.

No imminent hazards requiring removal actions per $40 C F R 300.415$ were identified to be currently associated with Building 3028. 


\section{Remedial Site Evaluation}

Is a Remedial Site Evaluation needed?

Areas of radiologic contamination associated with Building 3028 have been identified and marked as appropriate. However, it is suspected that process and LLLW drains and associated piping may have leaked beneath the slab of the building as a result of past practices. As a result, it is recommended that some type of remedial investigation be performed to assess the condition of the soil in this area before conducting any S\&M or D\&D activities which involve disturbing the slab.

Asbestos containing material has also been identified, marked and documented. No further remedial investigation involving this hazard is considered necessary given the current status and future plans of this facility.

Based on the age of the facility, painted surfaces are assumed to contain lead. Samples of the paint should be taken and analyzed to verify the presence of lead prior to conducting any S\&M or D\&D activities which may disturb these assumed areas.

\section{No Further Investigation}

Is a finding of No Further Investigation appropriate? Please explain.

A finding of No Further Investigation implies that a facility or area is free from hazardous substances or contaminants that may threaten human health and the environment. Since Building 3028 contains substances and materials which may become threatening if not properly controlled, handled and managed during the $S \& M$ cycle, a finding of No Further Investigation is inappropriate in this case.

\section{Additional Comments}

The following documents and databases were referenced for historical and hazard information related to Building 3028:

- Phase 1 Safety Documentation, Radioisotope Laboratory A, Building 3028 - Hazard Screening, Document No. HS/3028/F/RI-5 (Rev. 1)

- Work Plan for the Isotopes Facilities Deactivation Project at Oak Ridge National Laboratory, Document No. ORNL/ER-249/R2.

- Building 3028 Occurrence Reports, 1989 to present.

- Site Characterization Summary Report for Waste Area Grouping 1 at Oak Ridge National Laboratory, Oak Ridge, Tennessee, Volumes 1 and 2, Document Nos. DOE/OR-1043/V1\&D1 and DOE/OR-1043/V2\&D1.

- ORNL Hazardous Material Information System Database.

- ORNL Drain System Survey Report for Building 3028.

The following personnel and offices were contacted and provided historical and current use/condition information for Building 3028:

- Mr. Karl Haff, Radiochemical Processing Department Head, ORNL Radiochemical Technology Section.

- Mr. R.E. Eversole, Project Manager, Isotopes Facilities Deactivation Project, LMES.

- Ms. Swati Wilson, Manager, ORNL Lead Management Program.

- Mr. Nathan Dunn, Hazardous Material Information System Office.

- Mr. Jade Thomas, ORNL Environmental Compliance Office.

- Mr. Joe Armento, ORNL Chemical Technology Division, Isotopes Facilities Shutdown Program. 
$5-10$

The RISE of this facility was conducted for LMES under contract by:

Advanced Sciences, Inc.

800 Oak Ridge Turnpike, Suite C-102

Oak Ridge, TN

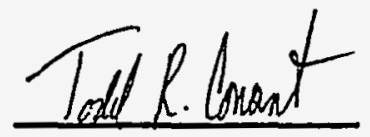

Evaluator's Signature

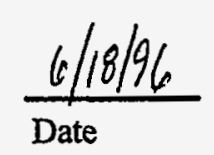




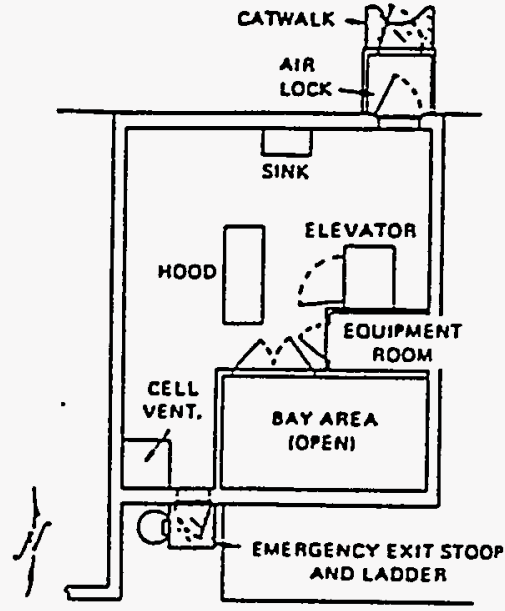

Second Floor

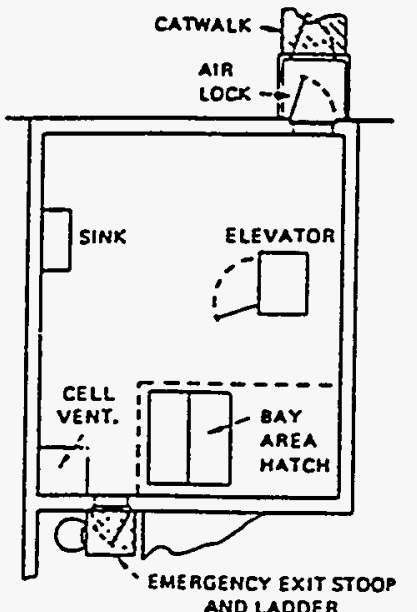

Third Floor

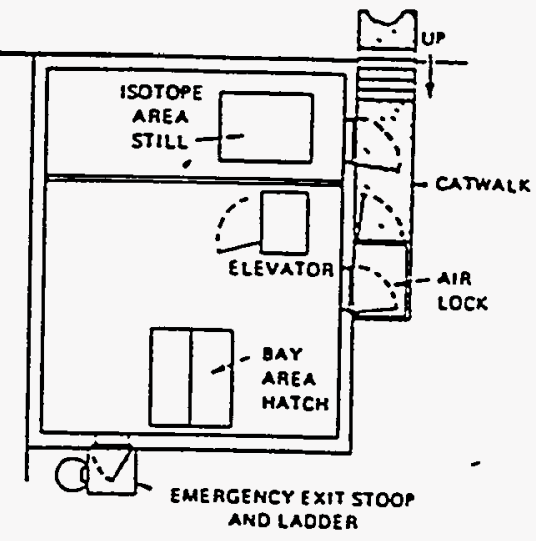

Fourth Floor

Upper Floors Building 3028

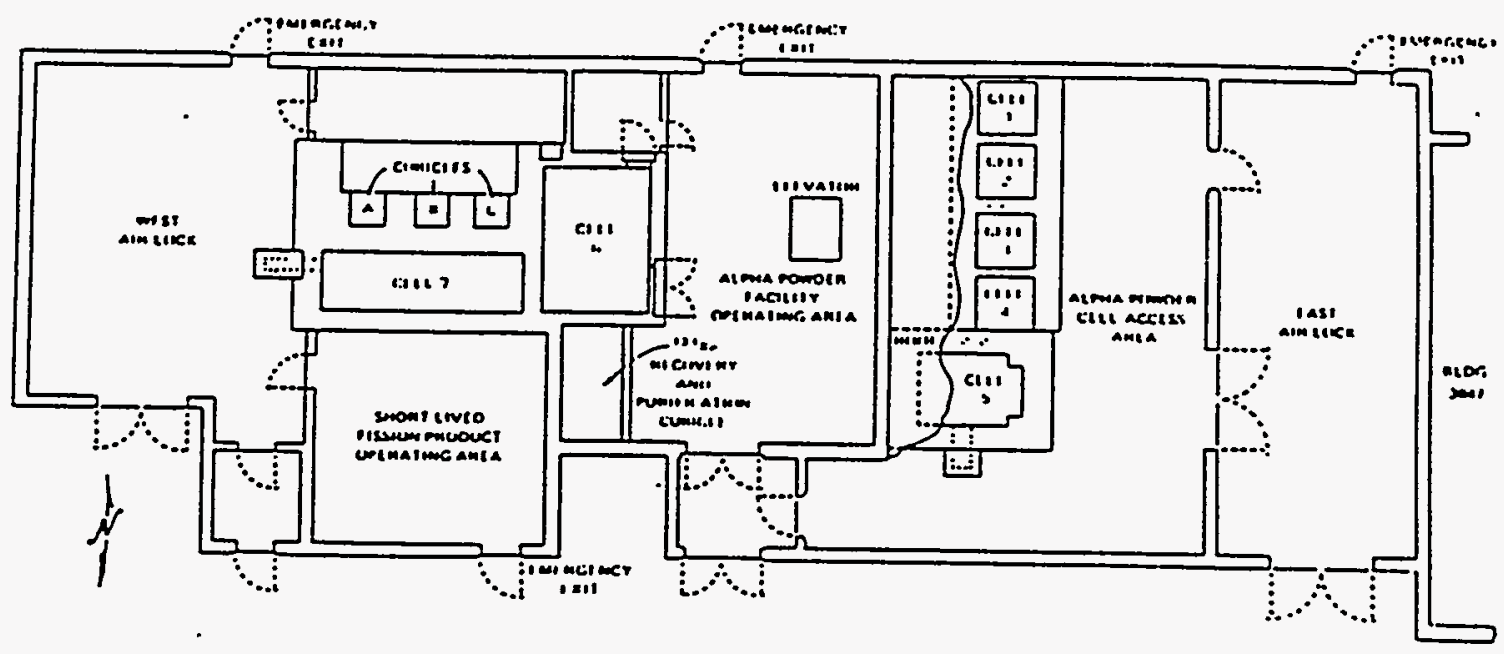

First Floor Building 3028

Fig. 5. Diagrams of Building 3028. 



\section{BUILDING 3029-SOURCE DEVELOPMENT LABORATORY}


ORNL FACILITY RmSE INFORMATION FORM

\begin{tabular}{|c|c|}
\hline \multicolumn{2}{|c|}{ General Information } \\
\hline $\begin{array}{l}\text { Building } 3029 \\
\text { The Source Development Lal }\end{array}$ & \\
\hline \multicolumn{2}{|c|}{$\begin{array}{ll}\text { Organization responsible for arealfacility } & \\
\text { (include specific person and phone number if possible): } & \text { R.E. Eversole (576-7483), } \\
& \text { IFDP Project Manager, } \\
& \text { ER Program, LMES }\end{array}$} \\
\hline Inactive, Standby Mode & Years of Operation: $\approx 40$ \\
\hline \multicolumn{2}{|c|}{ 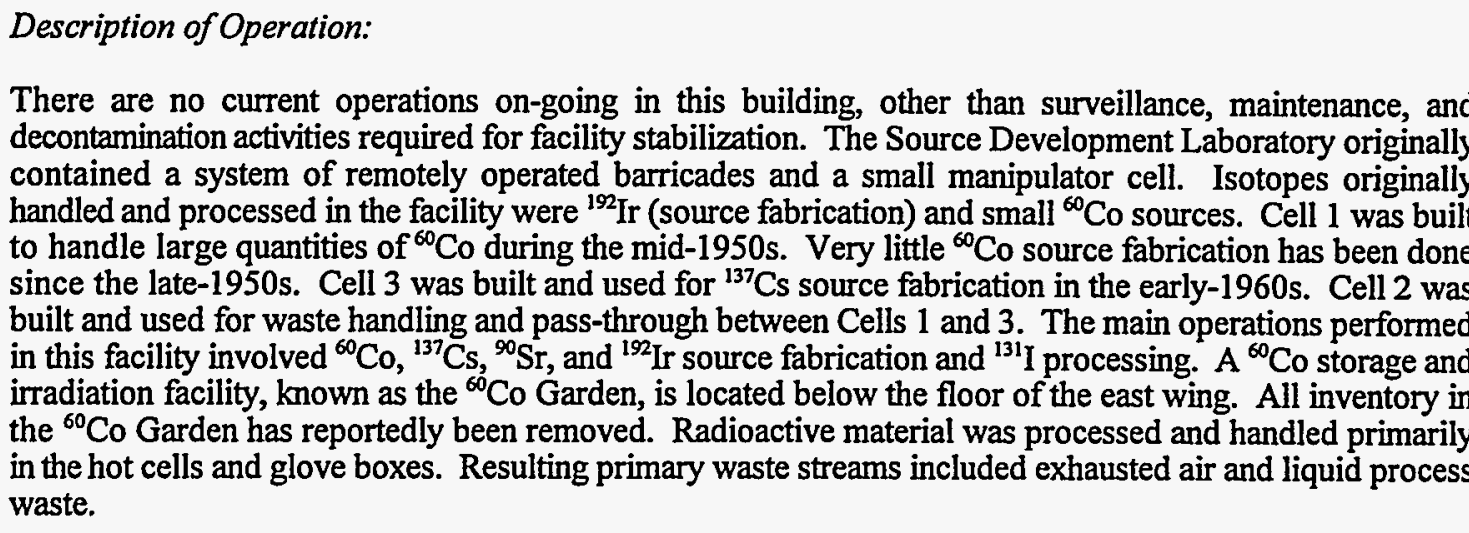 } \\
\hline \multicolumn{2}{|c|}{$\begin{array}{l}\text { Physical description of arealfacility: } \\
\text { - Building } 3029 \text { was originally constructed in } 1952 \text {. } \\
\text { The facility is a single-story, metal frame building with metal siding consisting of approximately } \\
\text { 3,000 sq. ft. of floor space. } \\
\text { The exterior of the building is cocooned with polyurethane foam for containment. } \\
\text { Building } 3029 \text { is located in an industrial area of ORNL (Isotopes Circle). The immediate area } \\
\text { surrounding the facility is paved. } \\
\text { Building utilities include electric, steam, and plant air. } \\
\text { The building currently consists primarily of four hot cells and associated operating areas and process } \\
\text { equipment. Work involving radioactive materials was performed primarily in the hot cells and glove } \\
\text { boxes. } \\
\text { The building and hot cells are kept under negative pressure for containment purposes. Building } \\
\text { ventilation is local and exhausts through high efficiency particulate air (HEPA) filters on the roof. Cell } \\
\text { ventilation exhausts through HEPA filters to the cell ventilation system and stack } 3039 \text {. } \\
\text { Building sinks and floor drains discharge to process waste system. Cell drains discharge to the low- } \\
\text { level liquid waste (LLLW) system (Tank WC-10). } \\
\text { Exterior of the building is in good condition with no visual evidence of significant damage or } \\
\text { deterioration. } \\
\text { Access to some of the interior portions (i.e., the East Wing) of the building was restricted during the } \\
\text { facility inspection. The interior areas of the building that were accessible were observed to be in fair } \\
\text { to good condition without any significant areas of damage or deterioration. } \\
\text { A building space diagram is attached to this form showing the location of the various process areas and } \\
\text { equipment. }\end{array}$} \\
\hline
\end{tabular}




\section{Release Information}

Description of release, or threatened release, and source:

Low levels of residual fixed and transferable radiologic surface contamination exist in areas of the facility as a result of historical operations. The contamination exists primarily in the hot cells, ${ }^{60} \mathrm{Co}$ Garden, and related process equipment (vessels, hoods, piping, ventilation ducts, etc.). This contamination has accumulated from activities involving a variety of materials throughout the operating history of the facility and, therefore, cannot be attributed to a single release episode. Specific areas of contamination include the drain to Glove Box B which has leaked and contaminated the area beneath the box with $\alpha$ contamination. Attempts have been made to clean this area to acceptable levels without success. The area currently is sealed and isolated. Also, the access area behind Cells 2 and 3 in the East Wing of the building has been zoned as a radiation contamination area as the result of ${ }^{137} \mathrm{Cs}$ contamination which leaked from Cell 3 . Clean up efforts to decontaminate this area were on-going at the time of this writing. The existing levels of RAD contamination in the facility are low and the presence of this contamination is not considered a significant hazard in its current state according to the Building 3029 Hazard Screening Report.

Hazardous materials (HAZMATs) (e.g., acids, hydraulic fluids, and other chemicals) were reportedly used in small quantities (i.e., less than 5 gallons or 100 pounds) during facility operations and currently for surveillance and maintenance (S\&M) activities. According to available spill/release records and facility personnel interviews, no significant HAZMAT spills (i.e., spills having the potential to adversely affect human health and/or the environment) have been reported for this building. No current conditions were identified which present a potential for a significant HAZMAT release.

Hazardous substances present:

Hazardous substances remaining in Building 3029 consist mainly of residual RAD surface contamination $(\alpha, \beta, \gamma)$, PCBs, and a small quantity of miscellaneous HAZMATs. Areas of fixed and transferable RAD contamination are associated primarily with the hot cells, ${ }^{60} \mathrm{Co}$ Garden, and process equipment. PCBs are reportedly present in the form of fork lift hydraulic fluid within the building. The Hazard Screening Report for this facility indicates that small quantities of HAZMATs are currently used for S\&M activities; however, an inventory list was not identified during this RmSE.

Estimate (if possible) of quantities of hazardous substances that have been released and that could be released:

The following represents the known quantities of substances currently existing in the facility. Radiologic surface contamination has accumulated from a legacy of many different programs and processes and cannot be attributed to a single release episode. It is only possible to quantify release amounts from contamination which currently exists in the facility and/or has been historically documented from past activities.

$0 \mu \mathrm{Ci} \alpha$ contamination in facility (Hazard Screening Report indicates "no alpha contamination present"; however, IFDP Work Plan and facility personnel interviews indicate that the area under Glove Box B is alpha contaminated and sealed.)

$<700 \mu \mathrm{Ci} \beta / \gamma$ as ${ }^{90} \mathrm{Sr}$.

$\approx 2 \mathrm{Ci} \beta / \gamma$ as ${ }^{60} \mathrm{Co}$.

PCB quantity not known (assumed to be less than 1 gallon).

Quantity of miscellaneous HAZMATs unknown (assumed to be less than 5 gallons or 100 pounds).

(Radioactive material quantity estimates obtained from Building 3026-C Hazard Screening Report, PCB and HAZMAT quantities assumed based on visual inspection and available information.) 
Other pollutants or contaminants:

Asbestos containing material (ACM), primarily in the form of thermal system insulation, has been confirmed present in this building. ACM observed is in fair to good condition and poses no immediate health threat. Based on the age of the facility, interior and exterior painted surfaces are assumed to be lead-containing. Verification samples are taken by ORNL Lead Management Program personnel on an "as-needed" basis to confirm the presence of lead in the paint (i.e., when work activities will disturb the paint, or paint is found to be deteriorating and poses a health or environmental threat). Interior painted surfaces observed are in fair to good condition and pose no immediate health threat. Exterior paint is also in good condition with no visible evidence of significant damage or deterioration.

\section{Groundwater}

Are there any suspected impacts to groundwater? If yes, please describe. Include any impacts to drinking water sources.

Building 3029 is located in Waste Area Grouping (WAG) 1 at ORNL. Although no specific adverse spills or releases of hazardous substances threatening to groundwater were identified during this RmSE, it is suspected, based on available environmental studies conducted in WAG 1, that process and LLLW drains and associated piping may have leaked over the life of the facility, as evidenced by Glove Box B. Buried process and LLLW piping and some drains have been found to be deteriorated and leaking in other facilities and areas of WAG 1. Studies have determined that groundwater in WAG 1 has been both radiologically and chemically contaminated. Numerous man-made radionuclides have been detected in WAG 1 groundwater samples including many of those processed in Building 3029. It is likely that liquid waste from activities involving radioisotopes in Building 3029 have historically contributed to WAG 1 groundwater contamination. However, the radionuclides detected in the groundwater were common to the processes and activities in many other buildings in the area which makes it difficult to determine exactly which building is, or was, the source of contamination.

Because of the reported small quantities of chemicals historically and currently used in this facility, it is unlikely that such usage has significantly contributed to WAG 1 groundwater contamination. As part of the facility shutdown process, inactive process and LLLW drains within the building have reportedly been plugged to prevent further release. However, no documentation was available at the time of this report to verify which drains have actually been plugged and which have not. Information on drain locations and discharge points is available from the ORNL Engineering Support Office.

Other than the potential for historical impact to groundwater in WAG 1 via leaking process and LLLW lines external to the building, no existing immediate threat to groundwater was identified given the current status of the facility.

\section{Surface Water}

Are there any suspected impacts to surface water? If yes, please describe. Also describe the most likely surface water migration route(s), if applicable. Include any impacts to drinking water sources.

WAG 1 is essentially bound by Fifth Creek to the east, White Oak Creek (WOC) to the south, and First Creek to the west. First and Fifth creeks flow south into (WOC) which flows to the west and exits WAG 1 at the southwest corner. Storm water (from surface runoff and storm water drainage system) and treated water from the process waste system discharges into WOC. The only potential for direct impact to surface water from Building 3029 in its current state would be from lead-containing paint chips which fall off the exterior painted surfaces and find their way into the storm water drainage system and eventually to WOC. 
Are there any suspected impacts to surface water? If yes, please describe. Also describe the most likely surface water migration route(s), if applicable. Include any impacts to drinking water sources. (Continued)

Based on the age of this facility, it is assumed that painted surfaces contain lead. The exterior paint of Building 3029 is in good condition and there was no visible evidence of deterioration observed during the site inspection. Therefore, the potential for impact to surface water due to assumed exterior lead-based paint is considered slight.

Surface water may have also been indirectly impacted by leaking process and LLLW lines external to the building. Some of these lines are known to have shared a common trench with storm water drainage piping. Contamination from leaking waste lines could potentially enter deteriorated storm water piping and migrate to WOC. The three creeks bordering WAG 1 are groundwater discharge points. Therefore, groundwater contaminated by leaking waste lines could also potentially impact surface water in the area.

No existing immediate threats to surface water were identified to be associated with Building 3029 during this RmSE.

Air

Are there any suspected impacts due to air emissions? If yes, please describe.

The Hazard Screening Report prepared for Building 3029 indicates a slight potential for radiation exposure to personnel working inside and within the immediate vicinity of the facility exists due to potential airborne migration of radioactive particulates and physical contact with contaminated surfaces. Areas of RAD contamination are identified, marked, and controlled as appropriate throughout the facility to protect against inadvertent exposure to personnel. Air in the building is controlled by a local ventilation system which exhausts building air through high efficiency particulate air (HEPA) filters, keeping the building under slight negative pressure relative to atmosphere. Air in the hot cells is exhausted through the cell ventilation system to stack 3039, keeping the cells at a slight negative pressure relative to the interior of the building. Apart from catastrophic failure of the hot cells or ventilation systems, it is unlikely that radioactive air emissions from Building 3029 would impact personnel or the environment in its current state.

There is also a potential for impact to indoor air quality due to the presence of $A C M$ and assumed lead-based paint (LBP) should these materials be disturbed. The ACM and assumed LBP remaining in the building are not considered to be immediate threats to indoor quality in their current state.

\section{Soil}

Are there any suspected impacts to soil? If yes, please describe.

As stated for groundwater, there is also a potential for historical impact to soils in the area of Building 3029 due to leaking process and LLLW drain piping. Previous environmental studies have identified a soil contamination plume in the Isotopes Circle area and soil samples collected from the plume have detected radioisotopes common to the processes performed in Building 3029. Whether waste from Building 3029 has actually contributed to this contamination is unknown, given the information reviewed during this RmSE.

Since the area surrounding Building 3029 is paved, there is no potential for areas of soil adjacent to the facility to be impacted from lead if, in fact, exterior paint is found to be lead-containing. The exterior paint was observed to be good condition and does not pose an immediate threat in its current state.

It is unlikely that the small quantities of chemicals reportedly used in Building 3029 have significantly impacted soil in the surrounding area. 


\section{Release Beyond Facility or Reservation Boundaries}

Has or will the release migrate beyond the boundaries of the facility or reservation? If yes, please describe (including possible human or environmental receptors).

The following are considered potential scenarios where radiologic contamination could migrate beyond the facility or reservation boundaries:

- A person becomes inadvertently contaminated and leaves the facility/reservation undetected.

- Catastrophic failure of hot cells and/or contaminated equipment.

There is also a potential for assumed lead-containing paint which peels off of the building to be carried away with surface runoff during a rain event. Though these potentials exist, they are considered slight and unlikely due to the current status of the facility and the engineering/administrative controls that are in place to protect again such an event.

\section{Worker Safety}

Could the release pose a threat to workers? If yes, please describe.

Radiologically contaminated areas are isolated and well marked. Good radiation practices and standard operating procedures are enforced for worker safety. Personnel exiting the facility are required to "frisk" themselves to detect the presence of RAD contamination. Monitors and alarms are in place to detect any radioactive release within the building. PCB containing equipment and ACM are appropriately labeled. However, even with these safeguards in place, a potential threat to workers exists if safety measures are overlooked. This potential is not considered significant given the current status and level of activity of the building.

\section{Environmental Receptors}

Does the release pose a potential threat to environmental receptors? If yes, please describe. Include natural resources impacts.

No existing conditions posing an immediate significant threat to environmental receptors, including natural resources, were identified to be currently existing or associated with Building 3029 .

\section{Mitigation}

\section{What action(s) might be taken to abate/prevent release or impacts from release?}

- Continued utilization and enforcement of engineering and administrative controls that are currently in place to protect workers and monitor conditions and activities in the building.

- Continue S\&M activities per Procedure IP-900.

What actions are currently being taken to abate/prevent release or impacts from release?

Engineering and administrative controls are in place to control access to contaminated areas and to monitor conditions and activities within the facility for worker and environmental protection. Warning signs and labels are posted throughout the facility indicating RAD, ACM, and PCB hazard areas. Standard operating procedures are in place for building access and surveillance and maintenance activities to protect against inadvertent contact and disturbance of contaminated areas and materials. Radiologically contaminated areas are monitored periodically by ORNL health physics personnel. Personnel are "frisked" upon exit of the facility to detect the presence of radiologic contamination. 
What actions are currently being taken to abate/prevent release or impacts from release? (Continued)

The building is currently in surveillance and maintenance status awaiting entry into the Decontamination and Decommissioning (D\&D) Program. Inactive waste drains are reportedly plugged in contaminated areas to prevent inadvertent discharge of contamination beyond the facility. A groundwater monitoring program is in place to monitor contamination levels and migration in groundwater underlying WAG 1 . The building is inspected for structural changes after each natural incident (earthquake, tornado, or other severe storm), fire and/or man induced activity which could cause cracking, failure, or deterioration of the facility and/or equipment that may allow contamination to be released. No such conditions have been reported for Building 3029.

Current actions being taken to prevent further release and ensure worker safety in Building 3029 are considered adequate until D\&D activities begin.

\section{Other Environmental Authorities}

Is the release or threatened release potentially subject to other environmental statutory actions? If yes, please explain.

If paint is found to be lead-containing and samples fail the Toxicity Characteristic Leaching Procedure (TCLP) analysis, the building could qualify as a hazardous waste generator point under the Resource Conservation and Recovery Act (RCRA).

\section{Maintenance Actions}

Are maintenance actions necessary to eliminate potential threats to human health and the environment? If so, explain.

No existing potential hazards requiring maintenance actions were identified to be associated with Building 3029.

\section{Removal Actions}

Are Removal Actions necessary to eliminate immediate threats to human health and the environment? If so, explain.

No imminent hazards requiring removal actions per 40 CFR 300.415 were identified to be currently associated with Building 3029.

\section{Remedial Site Evaluation}

\section{Is a Remedial Site Evaluation needed?}

Areas of radiologic contamination associated with Building 3029 have been identified and marked as appropriate. However, it is suspected that process and LLLW drains and associated piping may have leaked beneath the slab of the building as a result of past practices. As a result, it is recommended that some type of remedial investigation be performed to assess the condition of the soil in this area before conducting any $S \& M$ or D\&D activities which involve disturbing the slab.

$\mathrm{ACM}$ and $\mathrm{PCB}$-containing equipment have also been identified, marked and documented. No further remedial investigation involving these hazards is considered necessary given the current status and future plans of this facility.

Based on the age of the facility, painted surfaces are assumed to contain lead. Samples of the paint should be taken and analyzed to verify the presence of lead prior to conducting any S\&M or D\&D activities which may disturb these assumed areas. 
No Further Investigation

Is a finding of No Further Investigation appropriate? Please explain.

A finding of No Further Investigation implies that a facility or area is free from hazardous substances or contaminants that may threaten human health and the environment. Since Building 3029 contains substances and materials which may become threatening if not properly controlled, handled and managed during the S\&M cycle, a finding of No Further Investigation is inappropriate in this case.

\section{Additional Comments}

The following documents and databases were referenced for historical and hazard information related to Building 3029:

- Phase I Safety Documentation, The Source Development Laboratory, Building 3029, Hazard Screening, Document No. HS/3029/F/RT-6 (Rev. 1).

- Work Plan for the Isotopes Facilities Deactivation Project at Oak Ridge National Laboratory, Document No. ORNL/ER-249/R2.

- Building 3029 Occurrence Reports, 1989 to present.

- Site Characterization Summary Report for Waste Area Grouping 1 at Oak Ridge National Laboratory, Oak Ridge, Tennessee, Volumes 1 and 2, Document Nos. DOE/OR-1043/V1\&D1 and DOE/OR-1043/V2\&D1.

- ORNL Hazardous Material Information System Database.

- ORNL Drain System Survey Report for Building 3029.

The following personnel and offices were contacted and provided historical and current use/condition information for Building 3026-C:

- Mr. Karl Haff, Radiochemical Processing Department Head, ORNL Radiochemical Technology Section.

- Ms. Swati Wilson, Manager, ORNL Lead Management Program.

- Mr. Nathan Dunn, Hazardous Material Information System Office.

- Mr. Jade Thomas, ORNL Environmental Compliance Office.

- Mr. Joe Armento, ORNL Chemical Technology Division, Isotopes Facilities Shutdown Program.

The RmSE of this facility was conducted for LMES under contract by:

Advanced Sciences, Inc.

800 Oak Ridge Turnpike, Suite C-102

Oak Ridge, TN

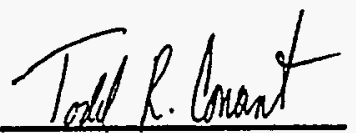

Evaluator's Signature

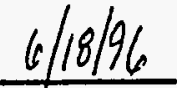

Date 
OANL DWG 90-601

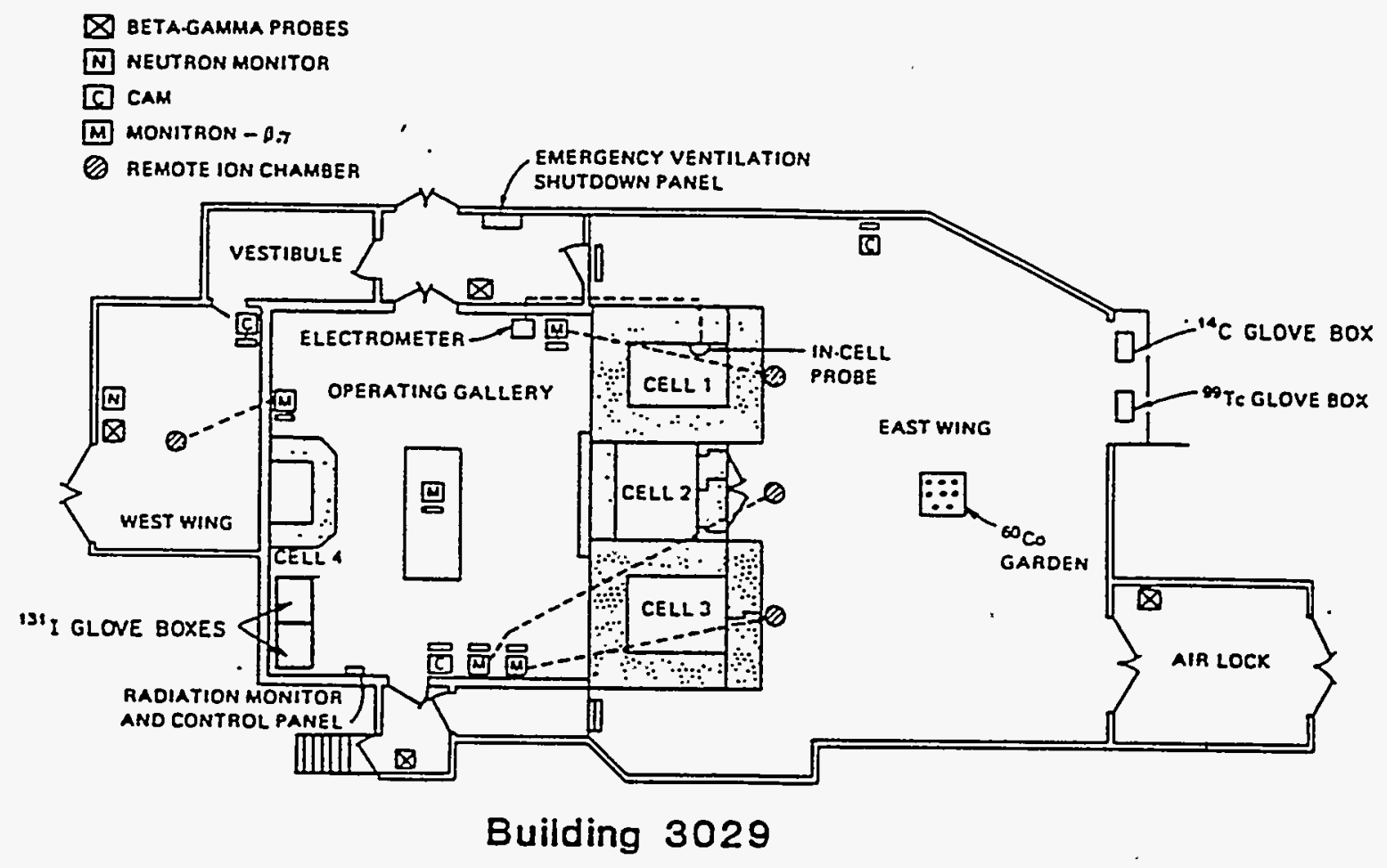

Fig. 6. Diagram of Building 3029. 
7. BUILDINGS 3030, 3031, AND 3118-ISOTOPES PRODUCTION LABS C, D, AND H 

ORNL FACILITY RmSE INFORMATION FORM

\begin{tabular}{|c|c|}
\hline \multicolumn{2}{|c|}{ General Information } \\
\hline $\begin{array}{l}\text { Building } 3030 / 3031 / 3118 \\
\text { Radioisotopes Production Lal }\end{array}$ & ories $\mathrm{C}, \mathrm{D}$, and $\mathrm{H}$ \\
\hline \multicolumn{2}{|l|}{$\begin{array}{l}\text { Organization responsible for arealfacility } \\
\text { (include specific person and phone number if possible): }\end{array}$} \\
\hline Inactive, Standby Mode & Years of Operation: $\approx 40$ \\
\hline \multicolumn{2}{|c|}{$\begin{array}{l}\text { Description of Operation: } \\
\text { There are no current operations, other than surveillance, maintenance, and deactivation activities, on-going } \\
\text { in these buildings. Historical operations involving radioisotopes were performed in Buildings } 3030 \text { and } \\
3031 \text {. Building } 3118 \text { was built in the early } 1960 \text { s by enclosing the area between Buildings } 3030 \text { and } 3031 \text {. } \\
\text { Building } 3118 \text { was used primarily for temporary storage of radioactive sources and contaminated wastes } \\
\text { and rear access to the hot cells in Building } 3030 \text { and } 3031 \text {. Operations in Buildings } 3030 \text { and } 3031 \text { consisted } \\
\text { of limited production and development work with radioisotopes used for industrial, medical, and research } \\
\text { applications. Operations have included purifying, processing, dispensing, and storage of radioactive } \\
\text { isotopes. The hot cell in Building } 3030 \text { has been used for processing isotopes such as }{ }^{56} \mathrm{Co},{ }^{57} \mathrm{Co},{ }^{198} \mathrm{Au}{ }^{55} \mathrm{Fe}, \\
{ }^{24} \mathrm{~Np},{ }^{75} \mathrm{Se},{ }^{90} \mathrm{Sr},{ }^{119 m} \mathrm{Sn},{ }^{237} \mathrm{U},{ }^{33} \mathrm{P} \text {, and }{ }^{192} \mathrm{Ir} \text {. The hot cell in Building } 3031 \text { was utilized for the final separation } \\
\text { of }{ }^{153} \mathrm{Gd} \text { from europium targets. Radioisotope processing and handling was performed in contained hot cells, } \\
\text { lab hoods, and glove boxes. Resulting primary waste streams included exhausted air and liquid process } \\
\text { waste. }\end{array}$} \\
\hline \multicolumn{2}{|c|}{$\begin{array}{l}\text { Physical description of area/facility: } \\
\text { - Buildings } 3030 \text { and } 3031 \text { were assumed to be constructed in the late } 1940 \text { s, based on the documented } \\
\text { construction date of surrounding buildings. Building } 3118 \text { was constructed in the early } 1960 \text { s. } \\
\text { The buildings are single-story, metal framed structures with metal siding. The exterior polyurethane } \\
\text { cocooning process has only been partially completed on Building } 3031 \text {; therefore, the buildings are not } \\
\text { sealed. } \\
\text { Buildings } 3030,3031 \text {, and } 3118 \text { are physically connected and share utilities (steam, electric, plant air). } \\
\text { These buildings are located in an industrial area of ORNL (Isotopes Circle). The immediate area } \\
\text { surrounding the facilities is paved for the most part with some grassy areas. } \\
\text { Buildings } 3030 \text { and } 3031 \text { are single-room laboratories each consisting of a hot cell, a monitor, process } \\
\text { hoods, and other laboratory equipment. Building } 3118 \text { is a single-room storage area consisting of rear } \\
\text { access doors to each hot cell in Buildings } 3030 \text { and } 3031 \text {. Floor drains in each building discharge to } \\
\text { the process and low-level liquid waste (LLLW) (Tank WC10) systems. Cell, hood, and glove box hot } \\
\text { drains discharge to the LLLW system (Tank WC10). The cells are currently shutdown. Work with } \\
\text { radioactive materials was performed in the hot cells, hoods, and glove boxes. } \\
\text { Generally, the interior of each building is in fair to good condition. Asbestos Containing Material } \\
\text { (ACM), radiation (RAD) hazard areas, and polychlorinated bi-phenol (PCB) containing equipment are } \\
\text { posted and/or labeled as appropriate. } \\
\text { Buildings } 3030 \text { and } 3031 \text { are kept under slight negative pressure relative to atmosphere. } \\
\text { Building space diagrams are attached to this form showing the locations of the various process areas and } \\
\text { equipment. }\end{array}$} \\
\hline
\end{tabular}




\section{Hazardous substances present:}

Hazardous substances remaining in Buildings 3030,3031 and 3118 consist mainly of small amounts of residual fixed $\operatorname{RAD}$ surface contamination $(\alpha, \beta, \gamma), \mathrm{PCBs}$, and a small quantity of miscellaneous HAZMATs. Areas of fixed RAD contamination are associated primarily with the hot cells and process equipment. PCBs are present in electrical capacitors within the buildings. The Hazard Screening Report for these facilities indicates that small quantities of HAZMATs are currently used for S\&M activities; however, an inventory list was not identified during this RmSE.

Estimate (if possible) of quantities of hazardous substances that have been released and that could be released:

The following represents the known quantities of substances currently existing in the facility. Radiologic surface contamination has accumulated from a legacy of many different programs and processes and cannot be attributed to a single release episode. It is only possible to quantify release amounts from contamination which currently exists in the facility and/or has been historically documented from past activities.

- Quantities of $\beta / \gamma$ and $\alpha$ contamination were reported as "residual contamination" and "traces (very low)", respectively, in the Hazard Screening Report for these facilities.

$\approx .5$ gallons PCBs.

(Quantity estimates obtained from Building 3030, 3031, and 3118 Hazard Screening Report, and ORNL PCB Large High- and Low-Voitage and Small Capacitor Inventory database)

\section{Other pollutants or contaminants:}

Asbestos containing material, primarily in the form of thermal system insulation, has been confirmed present in this building. ACM observed is in fair-to-good condition and poses no immediate health threat. Based on the age of the facility, interior and exterior painted surfaces are assumed to be lead-containing.

Verification samples are taken by ORNL Lead Management Program personnel on an "as-needed" basis to confirm the presence of lead in the paint (i.e., when work activities will disturb the paint, or paint is found to be deteriorating and poses a health or environmental threat). Interior painted surfaces observed are in fair to good condition and pose no immediate health threat. Paint on exterior surfaces was also found to be in good condition, posing no immediate hazard to the surrounding area due to deterioration. 


\section{Groundwater}

Are there any suspected impacts to groundwater? If yes, please describe. Include any impacts to drinking water sources.

Buildings 3030, 3031, and 3118 are located in Waste Area Grouping 1 at ORNL. Although no specific adverse spills or releases of hazardous substances threatening to groundwater were identified during this RmSE, it is suspected, based on available environmental studies conducted in WAG 1, that process and LLLW drains and associated piping may have leaked over the life of the facilities. Buried process and LLLW piping and some drains have been found to be deteriorated and leaking in other facilities and areas of WAG 1. Studies have determined that groundwater in WAG 1 has been both radiologically and chemically contaminated. Numerous man-made radionuclides have been detected in WAG 1 groundwater samples including those common to the processes in Buildings 3030 and 3031 . It is likely that liquid waste from activities involving radioisotopes in these buildings have historically contributed to WAG 1 groundwater contamination. However, the radionuclides detected in the groundwater were common to the processes and activities in many other buildings in the area which makes it difficult to determine exactly which building is, or was, the source of contamination.

Because of the reported small quantities of chemicals historically used in this facility, it is unlikely that such usage has significantly contributed to WAG 1 groundwater contamination. As part of the facility shutdown process, inactive process and LLLW drains within the building have reportedly been plugged to prevent further release. However, no documentation was available at the time of this report to verify which drains have actually been plugged and which have not. Information on drain locations and discharge points is available from the ORNL Engineering Support Office.

Other than the potential for historical impact to groundwater in WAG 1 via leaking process and LLLW lines external to the building, no existing immediate threat to groundwater was identified given the current status of these facilities.

\section{Surface Water}

Are there any suspected impacts to surface water? If yes, please describe. Also describe the most likely surface water migration route(s), if applicable. Include any impacts to drinking water sources.

WAG 1 is essentially bound by Fifth Creek to the east, White Oak Creek (WOC) to the south, and First Creek to the west. First and Fifth creeks flow south into (WOC) which flows to the west and exits WAG 1 at the southwest corner. Storm water (from surface runoff and storm water drainage system) and treated water from the process waste system discharges into WOC. Surface water may have been indirectly impacted by leaking process and LLLW lines external to the building. Some of these lines are known to have shared a common trench with storm water drainage piping. Contamination from leaking waste lines could potentially enter deteriorated storm water piping and migrate to WOC. The three creeks bordering WAG 1 are groundwater discharge points. Therefore, groundwater contaminated by leaking waste lines could also potentially impact surface water in the area.

Are there any suspected impacts to surface water? If yes, please describe. Also describe the most likely surface water migration route(s), if applicable. Include any impacts to drinking water sources. (Continued)

Additionally, if exterior painted surfaces do, in fact, contain lead, the potential exits for surface water to be impacted from deteriorated paint which washes of the buildings and finds its way to surface water with the storm water runoff.

Other than the potential for historical impact, no existing immediate threat to surface water was identified given the current status of these facilities. 


\begin{abstract}
Air
Are there any suspected impacts due to air emissions? If yes, please describe.

The Hazard Screening Report prepared for Buildings 3030, 3031, and 3118 indicates a slight potential for radiation exposure to personnel working inside the facilities exists due to potential airborne migration of radioactive particulates and physical contact with contaminated surfaces. Because of the low levels and nature of RAD contamination within the facilities, impacts to persons or the environment surrounding the facilities are considered negligible. Areas of RAD contamination are identified, marked, and controlled as appropriate throughout the facilities to protect against inadvertent exposure to personnel. Air in the buildings is controlled by a local exhaust system which exhausts laboratory hood air through high efficiency particulate air (HEPA) filters. Hot cells are exhausted through HEPA filters to the 3039 stack. Apart from catastrophic failure of the hot cells or ventilation system, it is unlikely that radioactive air emissions from these buildings would impact personnel or the environment.

There is also a potential for impact to indoor air quality due to the presence of ACM and assumed lead-based paint (LBP) should these materials be disturbed. The ACM and assumed LBP remaining in the building are not considered to be immediate threats to indoor quality in their current state.
\end{abstract}

\title{
Soil
}

Are there any suspected impacts to soil? If yes, please describe.

As stated for groundwater, there is a potential for historical impact to soils in the area of Buildings 3030 , 3031 , and 3118 due to leaking process and LLLW drain piping. Previous environmental studies have identified a soil contamination plume in the Isotopes Circle area and soil samples collected from the plume have detected radioisotopes common to the processes performed in these building. An area of contaminated soil exists around the southwest corner of Building 3030. The area is well marked and covered with a protective barrier and river rock. Below-ground LLLW drains have been identified in this area. Information specific to this area was not identified during this RmSE; however, it is likely that this area of contamination is a result of leaks in the LLLW drain lines. As a result, it is also likely that operations in these facilities (at least Building 3030) have historically contributed to the Isotopes Circle soil contamination plume. This area of contamination is not considered an imminent hazard given the current status of the adjacent facility and the protective measures being taken to prevent contamination migration and personnel exposure.

It is unlikely that the small quantities of chemicals used in these facilities have significantly impacted soil in the surrounding area.

Release Beyond Facility or Reservation Boundaries

Has or will the release migrate beyond the boundaries of the facility or reservation? If yes, please describe (including possible human or environmental receptors).

The following are considered potential scenarios where radiologic contamination could migrate beyond the facility or reservation boundaries:

- A person becomes inadvertently contaminated and leaves the facility/reservation undetected.

- Catastrophic failure of hot cells and/or contaminated equipment.

There is also a potential for assumed lead-containing paint which peels off exterior surfaces of the buildings to be carried away with surface runoff during a rain event. Though these potentials exist, they are considered slight and unlikely due to the current status of the facility and the engineering/administrative controls that are in place to protect again such an event. 


\begin{abstract}
\begin{tabular}{|c|}
\hline Worker Safety \\
\hline Could the releaseposea threat roworkers?
\end{tabular}
Could the release pose a threat to workers? If yes, please describe.

Radiologically contaminated areas are isolated and well marked. Good radiation practices and standard operating procedures are enforced for worker safety. Personnel exiting the facilities are required to "frisk" themselves to detect the presence of RAD contamination. Monitors and alarms are in place in Buildings 3030 and 3031 to detect any radioactive release within the buildings. PCB containing equipment and ACM are appropriately labeled. However, even with these safeguards in place, a potential threat to workers exists if safety measures are overlooked. This potential is not considered significant given the current status and level of activity of buildings.
\end{abstract}

\title{
Environmental Receptors
}

Does the release pose a potential threat to environmental receptors? If yes, please describe. Include natural resources impacts.

No existing conditions posing an immediate significant threat to environmental receptors, including natural resources, were identified to be currently existing or associated with Building 3030, 3031 or 3118 .

\section{Mitigation}

What action(s) might be taken to abate/prevent release or impacts from release?

- Continued utilization and enforcement of engineering and administrative controls that are currently in place to protect workers and monitor conditions and activities in these buildings.

- Continue S\&M activities per Procedure IP-900.

What actions are currently being taken to abate/prevent release or impacts from release?

Engineering and administrative controls are in place to control access to contaminated areas and to monitor conditions and activities within the facilities for worker and environmental protection. Warning signs and labels are posted throughout the facilities indicating RAD, ACM, and PCB hazard areas. Standard operating procedures are in place for building access and surveillance and maintenance activities to protect against inadvertent contact and disturbance of contaminated areas and materials. Radiologically contaminated areas are monitored periodically by ORNL health physics personnel. Personnel are "frisked" upon exit of each facility to detect the presence of radiologic contamination. The buildings are currently in surveillance and maintenance status awaiting entry into the Decontamination and Decommissioning (D\&D) Program. Inactive waste drains are reportedly plugged in contaminated areas to prevent inadvertent discharge of contamination beyond the facility. A groundwater monitoring program is in place to monitor contamination levels and migration in groundwater underlying WAG 1. The building is inspected for structural changes after each natural incident (earthquake, tornado, or other severe storm), fire and/or man induced activity which could cause cracking, failure, or deterioration of the facility and/or equipment that may allow contamination to be released. No such conditions have been reported for Buildings 3030, 3031, and 3118 .

Current actions being taken to prevent further release and ensure worker safety in Buildings 3030, 3031, and 3118 are considered adequate until $D \& D$ activities begin.

Other Environmental Authorities

Is the release or threatened release potentially subject to other environmental statutory actions? If yes, please explain.

If paint is found to be lead-containing and samples fail the Toxicity Characteristic Leaching Procedure (TCLP) analysis, the building could qualify as a hazardous waste generator point under the Resource Conservation and Recovery Act (RCRA). 


\section{Maintenance Actions}

Are maintenance actions necessary to eliminate potential threats to human health and the environment? If so, explain.

No existing potential hazards requiring maintenance actions were identified to be associated with Buildings 3030,3031 , or 3118 .

\section{Removal Actions}

Are Removal Actions necessary to eliminate immediate threats to human health and the environment? If so, explain.

No imminent hazards requiring removal actions per 40 CFR 300.415 were identified to be currently associated with Buildings 3030, 3031, or 3118.

\section{Remedial Site Evaluation}

Is a Remedial Site Evaluation needed?

Areas of radiologic contamination associated with Buildings 3030,3031 , and 3118 have been identified and marked as appropriate. However, it is suspected that process and LLLW drains and associated piping may have leaked beneath the slab of the building as a result of past practices. As a result, it is recommended that some type of remedial investigation be performed to assess the condition of the soil in this area before conducting any S\&M or D\&D activities which involve disturbing the slab.

ACM and PCB-containing equipment have also been identified, marked and documented. No further remedial investigation involving these hazards is considered necessary given the current status and future plans of this facility.

Based on the age of the facility, painted surfaces are assumed to contain lead. Samples of the paint should be taken and analyzed to verify the presence of lead prior to conducting any S\&M or D\&D activities which may disturb these assumed areas.

\section{No Further Investigation}

Is a finding of No Further Investigation appropriate? Please explain.

A finding of No Further Investigation implies that a facility or area is free from hazardous substances or contaminants that may threaten human health and the environment. Since Buildings 3030, 3031, and 3118 contain substances and materials which may become threatening if not properly controlled, handled and managed during the S\&M cycle, a finding of No Further Investigation is inappropriate in this case. 


\section{Additional Comments}

The following documents and databases were referenced for historical and hazard information related to Buildings 3030, 3031, and 3118:

- Phase I Safety Documentation, Radioisotope Production Laboratories C, D, and H, Buildings 3030, 3031, and 3118, Hazard Screening, Document No. Draft.

- Work Plan for the Isotopes Facilities Deactivation Project at Oak Ridge National Laboratory, Document No. ORNL/ER-249/R2.

- Building 3030, 3031, and 3118 Occurrence Reports, 1989 to present.

- Site Characterization Summary Report for Waste Area Grouping 1 at Oak Ridge National Laboratory, Oak Ridge, Tennessee, Volumes 1 and 2, Document Nos. DOE/OR-1043/V1\&D1 and DOE/OR-1043/V2\&D1.

- ORNL Hazardous Material Information System Database.

- ORNL Drain System Survey Report for Buildings 3030, 3031, and 3118.

The following personnel and offices were contacted and provided historical and current use/condition information for Building 3030, 3031, and 3118:

- Mr. Karl Haff, Radiochemical Processing Department Head, ORNL Radiochemical Technology Section.

- Mr. Herman Phillips, Assistant Facilities Manager, ORNL Special Projects.

- Ms. Swati Wilson, Manager, ORNL Lead Management Program.

- Mr. Nathan Dunn, Hazardous Material Information System Office.

- Mr. Jade Thomas, ORNL Environmental Compliance Office.

- Mr. Joe Armento, ORNL Chemical Technology Division, Isotopes Facilities Shutdown Program.

The RmSE of this facility was conducted for LMES under contract by:

Advanced Sciences, Inc.

800 Oak Ridge Turnpike, Suite C-102

Oak Ridge, TN

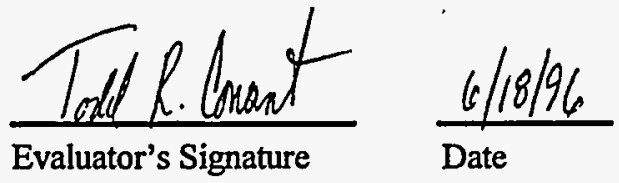




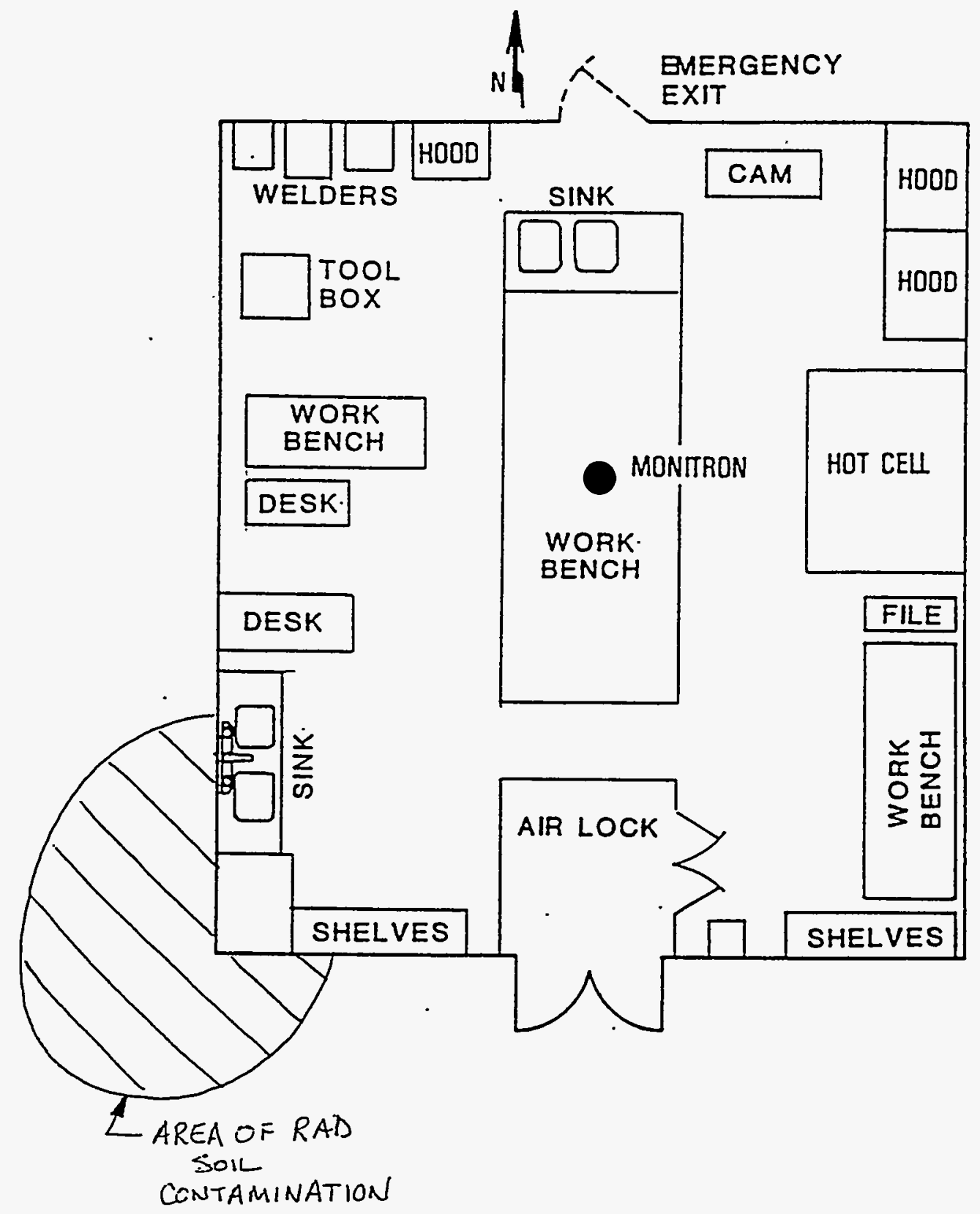

Fig. 7. Diagram of Building 3030. 
ORNL DWG $80-588$

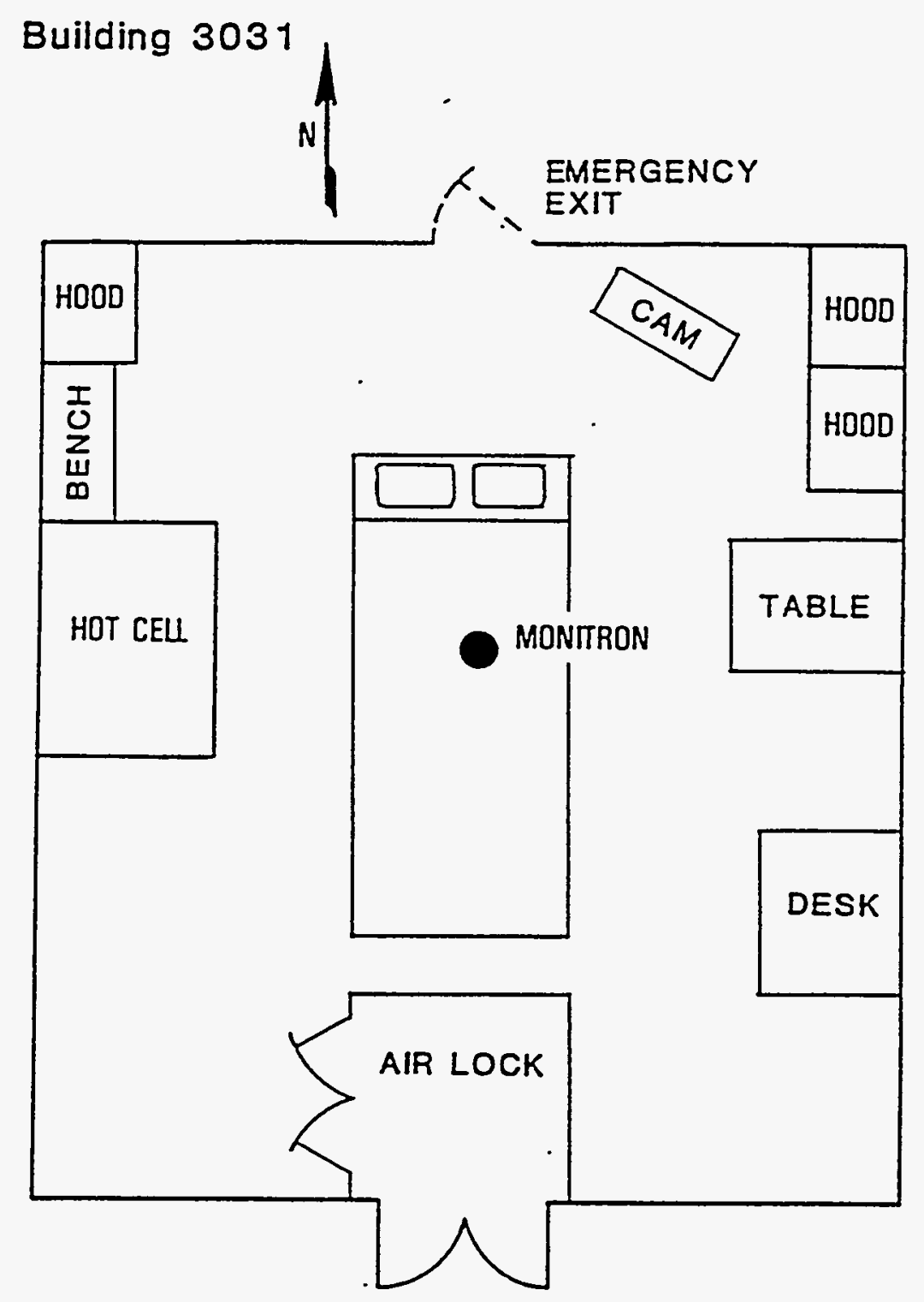

Fig. 8. Diagram of Building 3031. 


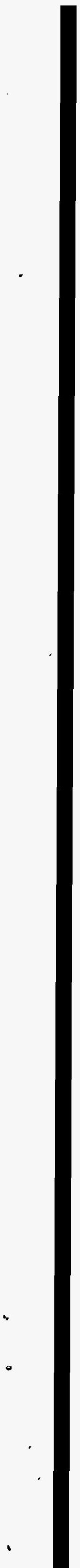




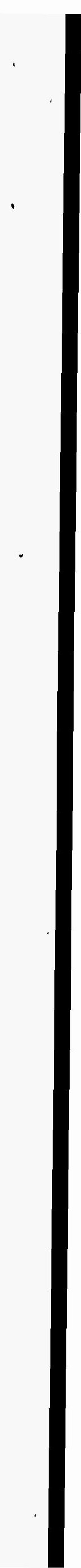




\section{ORNL FACILITY RmSE INFORMATION FORM}

\begin{tabular}{|c|c|c|}
\hline \multicolumn{3}{|c|}{ General Information } \\
\hline $\begin{array}{l}\text { Area/Facility Name } \\
\text { (and aliases): }\end{array}$ & \multicolumn{2}{|c|}{$\begin{array}{l}\text { Building } 3032 \text { (including Building 3099) } \\
\text { Radioisotope Production Laboratory E }\end{array}$} \\
\hline \multicolumn{3}{|c|}{$\begin{array}{ll}\text { Organization responsible for area/facility } & \\
\text { (include specific person and phone number if possible): } & \text { R.E. Eversole (576-7483), } \\
& \text { IFDP Project Manager, } \\
& \text { ER Program, LMES }\end{array}$} \\
\hline Inactive, Standby Mode & & Years of Operation: $\approx 40$ \\
\hline \multicolumn{3}{|c|}{$\begin{array}{l}\text { Description of Operation: } \\
\text { There are no current operations, other than surveillance, maintenance, and deactivation activities, on-going } \\
\text { in this building. Information on historical operations identified for Building } 3032 \text { during this RmSE was } \\
\text { not detailed. The building was originally built as part of the Isotopes Program, and it housed an analytica } \\
\text { facility for radiochemical support of the isotopes production activities. Currently, all discrete items o } \\
\text { radioactive material inventory have been removed. Radioisotope processing and handling was performed } \\
\text { in lab hoods. Resulting primary waste streams included exhausted air and liquid process waste } \\
\text { Building } 3099 \text { is actually a concrete storage pad adjacent to the west side of Building } 3032 \text {. This pad has } \\
\text { been used for temporary storage of many different items including containerized radioactive materials and } \\
\text { wastes. }\end{array}$} \\
\hline \multicolumn{3}{|c|}{$\begin{array}{l}\text { Physical description of arealfacility: } \\
\text { - Building } 3032 \text { was originally constructed in the } 1950 \text { s. } \\
\text { The building is a single-story, metal framed structure with metal siding consisting of } 1,200 \text { sq. ft. of } \\
\text { floor space. The building is not sealed by polyurethane cocooning. Paint observed on exterior surfaces } \\
\text { is in good condition. } \\
\text { Building } 3032 \text { is located in an industrial area of ORNL (Isotopes Circle). The immediate area } \\
\text { surrounding the facilities is paved for the most part with some grassy areas. } \\
\text { The building is basically a single-room laboratory consisting of a five process hoods and other } \\
\text { laboratory equipment. Floor drains in the building reportedly discharge to the process waste system. } \\
\text { Hood drains discharged to the low-level liquid waste (LLLW) system (Tank WC10). The Hazard } \\
\text { Screening report for this building indicates that LLLW service is no longer available. Work with } \\
\text { radioactive materials was performed in the process hoods. } \\
\text { Generally, the interior of the building is in fair to good condition. Asbestos Containing Material (ACM) } \\
\text { and radiation (RAD) hazard areas are posted and/or labeled as appropriate. No polychlorinated bi- } \\
\text { phenols (PCBs) were identified to be associated with this building. } \\
\text { Building } 3032 \text { is operated under normal atmospheric pressure. } \\
\text { A building space diagram is attached to this form showing the locations of the various process areas and } \\
\text { equipment. }\end{array}$} \\
\hline
\end{tabular}




\begin{tabular}{l} 
Release Information \\
\hline Description of release, or threatened release, and source: \\
Small amounts of residual fixed radiologic surface contamination and a few isolated areas of transferable \\
RAD contamination exist in areas of the facility as a result of historical operations. Accessible areas of \\
RAD contamination have been decontaminated and are considered "clean", according to the Hazard \\
Screening Report. Some small fixed and transferable hot spots remain in inaccessible areas, primarily in \\
the process hoods and related equipment. This contamination has accumulated from activities involving a \\
variety of materials throughout the operating history of the facility and, therefore, cannot be attributed to \\
a single release episode. The existing levels of RAD contamination in the facility are very low and well \\
isolated. The presence of this contamination is not considered a significant hazard in its current state. \\
It is assumed, based on the historical laboratory function of this building and operations in similar facilities, \\
that hazardous materials (HAZMATs) (e.g., acids, hydraulic fluids, and other chemicals) were used in small \\
quantities (i.e., less than 5 gallons or 100 pounds) during facility operations. Reportedly, no HAZMATs \\
are currently used or stored in this facility. According to available spill/release records and facility \\
personnel interviews, no significant HAZMAT spills (i.e., spills having the potential to adversely affect \\
human health and/or the environment) have been reported for this building. No current conditions were \\
identified which present a potential for a HAZMAT release.
\end{tabular}

Hazardous substances present:

Hazardous substances remaining in Building 3032 consist main of small amounts of residual fixed and transferable RAD surface contamination $(\alpha, \beta, \gamma)$. Areas of fixed RAD contamination are associated primarily with the process hoods and associated equipment. No PCBs were identified to be present in within the building.

Estimate (if possible) of quantities of hazardous substances that have been released and that could be released:

The following represents the known quantities of substances currently existing in the facility. Radiologic surface contamination has accumulated from a legacy of many different programs and processes and cannot be attributed to a single release episode. It is only possible to quantify release amounts from contamination which currently exists in the facility and/or has been historically documented from past activities.

$<400 \mu \mathrm{Ci} \alpha$

$<1,100 \mu \mathrm{Ci} \beta / \gamma$

(Quantity estimates obtained from Building 3032 Hazard Screening Report)

\section{Other pollutants or contaminants:}

Asbestos containing material, primarily in the form of thermal system insulation, has been confirmed present in this building. ACM observed is in fair to good condition and poses no immediate health threat. Based on the age of the facility, interior and exterior painted surfaces are assumed to be lead-containing. Verification samples are taken by ORNL Lead Management Program personnel on an "as-needed" basis to confirm the presence of lead in the paint (i.e., when work activities will disturb the paint, or paint is found to be deteriorating and poses a health or environmental threat). Interior painted surfaces observed are in fair to good condition and pose no immediate health threat. Paint on exterior surfaces was also found to be in good condition, posing no immediate hazard to the surrounding area due to deterioration. 
Groundwater

Are there any suspected impacts to groundwater? If yes, please describe. Include any impacts to drinking water sources.

Building 3032 is located in Waste Area Grouping 1 at ORNL. Although no specific adverse spills or releases of hazardous substances threatening to groundwater were identified during this RmSE, it is suspected, based on available environmental studies conducted in WAG 1, that process and LLLW drains and associated piping may have leaked over the life of the facility. Buried process and LLLW piping and some drains have been found to be deteriorated and leaking in other facilities and areas of WAG 1. Studies have determined that groundwater in WAG 1 has been both radiologically and chemically contaminated. Numerous man-made radionuclides have been detected in WAG 1 groundwater samples; however, because of the lack of specific information concerning radioisotope processes in Building 3032, it is not known whether any of these radionuclides were common to the processes in this building. It is likely, however, that liquid waste from activities involving radioisotopes in this building has historically contributed to WAG 1 groundwater contamination to some extent. However, the radionuclides detected in the groundwater were common to the processes and activities in many buildings in the area which makes it difficult to determine exactly which building is, or was, the source of contamination.

Because of the assumed small quantities of chemicals historically used in this facility, it is unlikely that such usage has significantly contributed to WAG 1 groundwater contamination. As part of the facility shutdown process, inactive process and LLLW drains within the building have reportedly been plugged to prevent further release. However, no documentation was available at the time of this report to verify which drains have actually been plugged and which have not. Information on drain locations and discharge points is available from the ORNL Engineering Support Office.

Other than the potential for historical impact to groundwater in WAG 1 via leaking process and LLLW lines external to the building, no existing immediate threat to groundwater was identified given the current status of the facility.

\section{Surface Water}

Are there any suspected impacts to surface water? If yes, please describe. Also describe the most likely surface water migration route(s), if applicable. Include any impacts to drinking water sources.

WAG 1 is essentially bound by Fith Creek to the east, White Oak Creek (WOC) to the south, and First Creek to the west. First and Fifth creeks flow south into (WOC) which flows to the west and exits WAG 1 at the southwest corner. Storm water (from surface runoff and storm water drainage system) and treated water from the process waste system discharges into WOC. Surface water may have been indirectly impacted by leaking process and LLLW lines external to the building. Some of these lines are known to have shared a common trench with storm water drainage piping. Contamination from leaking waste lines could potentially enter deteriorated storm water piping and migrate to WOC. The three creeks bordering WAG 1 are also groundwater discharge points; therefore, groundwater contaminated by leaking waste lines could also potentially impact surface water in the area.

Additionally, if exterior painted surfaces do, in fact, contain lead, the potential exits for surface water to be impacted from deteriorated paint which washes off the building and finds its way to surface water with the storm water runoff.

Other than the potential for historical impact, no existing immediate threat to surface water was identified given the current status of this facility. 
Air

Are there any suspected impacts due to air emissions? If yes, please describe.

The Hazard Screening Report prepared for Building 3032 indicates that there is no potential for significant radiation exposure to personnel working in or around this facility as a result of airborne migration of radioactive particulates and physical contact with contaminated surfaces. Areas of RAD contamination are identified, marked, and controlled as appropriate throughout the facility to protect against inadvertent exposure to personnel. Radiologic contamination in the building is controlled by a local exhaust system which exhausts building and hood air through high efficiency particulate air (HEPA) filters. Because of the small amounts of RAD contamination present, it is highly unlikely that radioactive air emissions from this building would impact personnel or the environment.

There is, however, a potential for impact to indoor air quality due to the presence of $\mathrm{ACM}$ and assumed lead-based paint (LBP) should these materials be disturbed. The ACM and assumed LBP remaining in the building are not considered to be immediate threats to indoor quality in their current state.

Soil

Are there any suspected impacts to soil? If yes, please describe.

As stated for groundwater, there is a potential for historical impact to soils in the area of Building 3032 due to leaking process and LLLW drain piping. Previous environmental studies have identified a soil contamination plume in the Isotopes Circle area and soil samples collected from the plume have detected radioisotopes common to many of the processes performed in the Isotopes Facilities. Even though specific radioisotopes processed in Building 3032 were not identified during this RmSE, it is likely that liquid waste from activities involving radioisotopes in this building has historically contributed to the Isotopes Circle contamination plume to some extent. However, the radionuclides detected in the soil were common to the processes and activities in many buildings in the area which makes it difficult to determine exactly which building is, or was, the source of contamination.

It is unlikely that the assumed small quantities of chemicals used in Building 3032 have impacted soil in the surrounding area.

\section{Release Beyond Facility or Reservation Boundaries}

Has or will the release migrate beyond the boundaries of the facility or reservation? If yes, please describe (including possible human or environmental receptors).

Because of the small amount and inaccessibility of existing radiologic contamination in Building 3032, there is considered to be no potential for significant radiologic release beyond the facility or reservation boundaries.

There is, however, a potential for assumed lead-containing paint which peels off exterior surfaces of the building to be carried away with surface runoff during a rain event. Though this potential exists, it is considered slight and unlikely due to the current status and condition of the facility.

Worker Safety

Could the release pose a threat to workers? If yes, please describe.

Radiologically contaminated areas are isolated and well marked. Good radiation practices and standard operating procedures are enforced for worker safety. Personnel exiting the facilities are required to "frisk" themselves to detect the presence of RAD contamination. ACM is appropriately labeled. However, even with these safeguards in place, a potential threat to workers exists if safety measures are overlooked and workers are careless. This potential is not considered significant given the current status and level of activity of this building. 
Environmental Receptors

Does the release pose a potential threat to environmental receptors? If yes, please describe. Include natural resources impacts.

No existing conditions posing an immediate significant threat to environmental receptors, including natural resources, were identified to be currently existing or associated with Building 3032.

\section{Mitigation}

What action(s) might be taken to abate/prevent release or impacts from release?

- Continued utilization and enforcement of engineering and administrative controls that are currently in place to protect workers and monitor conditions and activities in these buildings.

- Continue S\&M activities per Procedure IP-900.

What actions are currently being taken to abate/prevent release or impacts from release?

Engineering and administrative controls are in place to control access to contaminated areas and to monitor conditions and activities within the facility for worker and environmental protection. Warning signs and labels are posted as necessary indicating RAD and ACM hazard areas. Standard operating procedures are in place for building access and surveillance and maintenance activities to protect against inadvertent contact and disturbance of contaminated areas and materials. Radiologically contaminated areas are monitored periodically by ORNL health physics personnel. Personnel are "frisked" upon exit of the facility to detect the presence of radiologic contamination. The building is currently in surveillance and maintenance status awaiting entry into the Decontamination and Decommissioning (D\&D) Program. Inactive waste drains are reportedly plugged in contaminated areas to prevent inadvertent discharge of contamination beyond the facility. A groundwater monitoring program is in place to monitor contamination levels and migration in groundwater underlying WAG 1 . The building is inspected for structural changes after each natural incident (earthquake, tornado, or other severe storm), fire and/or man induced activity which could cause cracking, failure, or deterioration of the facility and/or equipment that may allow contamination to be released. No such conditions have been reported for Building 3032.

Current actions being taken to prevent further release and ensure worker safety in Buildings 3032 are considered adequate until $\mathrm{D} \& \mathrm{D}$ activities begin.

\section{Other Environmental Authorities}

Is the release or threatened release potentially subject to other environmental statutory actions? If yes, please explain.

If paint is found to be lead-containing and samples fail the Toxicity Characteristic Leaching Procedure (TCLP) analysis, the building could qualify as a hazardous waste generator point under the Resource Conservation and Recovery Act (RCRA).

\section{Maintenance Actions}

Are maintenance actions necessary to eliminate potential threats to human health and the environment? If so, explain.

No existing potential hazards requiring maintenance actions were identified to be associated with Building 3032. 


\begin{tabular}{|l}
\hline \multicolumn{1}{|c}{ Removal Actions } \\
\hline Are Remedial Actions necessary to eliminate immediate threats to human health and the environment? \\
If so, explain.
\end{tabular}

No imminent hazards requiring removal actions per 40 CFR 300.415 were identified to be currently associated with Building 3032 .

\section{Remedial Site Evaluation}

\section{Is a Remedial Site Evaluation needed?}

Areas of radiologic contamination associated with Buildings 3032 are marked as appropriate. However, it is suspected that process and LLLW drains and associated piping may have leaked beneath the slab of the building as a result of past practices. As a result, it is recommended that some type of remedial investigation be performed to assess the condition of the soil in this area before conducting any S\&M or D\&D activities which involve disturbing the slab.

ACM has also been identified, marked and documented. No further remedial investigation involving this hazards is considered necessary given the current status and future plans of this facility.

Based on the age of the facility, painted surfaces are assumed to contain lead. Samples of the paint should be taken and analyzed to verify the presence of lead prior to conducting any S\&M or D\&D activities which may disturb these assumed areas.

No Further Investigation

Is a finding of No Further Investigation appropriate? Please explain.

A finding of No Further Investigation implies that a facility or area is free from hazardous substances or contaminants that may threaten human health and the environment. Since Building 3032 contains substances and materials which may become threatening if not properly controlled, handled and managed during the S\&M cycle, a finding of No Further Investigation is inappropriate in this case.

Additional Comments

The following documents and databases were referenced for historical and hazard information related to Building 3032:

- Phase I Safety Documentation, Radioisotope Production Laboratory E, Building 3032 Hazard Screening, Document No. HS/3032/F/RT-9 (Rev.0).

- Work Plan for the Isotopes Facilities Deactivation Project at Oak Ridge National Laboratory, Document No. ORNL/ER-249/R2.

- Building 3032 Occurrence Reports, 1989 to present.

- Site Characterization Summary Report for Waste Area Grouping 1 at Oak Ridge National Laboratory, Oak Ridge, Tennessee, Volumes 1 and 2, Document Nos. DOE/OR-1043/V1\&D1 and DOE/OR-1043/V2\&D1.

- ORNL Hazardous Material Information System Database.

- ORNL Drain System Survey Report for Building 3032.

The following personnel and offices were contacted and provided historical and current use/condition information for Building 3032:

- Mr. Karl Haff, Radiochemical Processing Department Head, ORNL Radiochemical Technology Section.

- Ms. Swati Wilson, Manager, ORNL Lead Management Program.

- Mr. Nathan Dunn, Hazardous Material Information System Office.

- Mr. Jade Thomas, ORNL Environmental Compliance Office.

- Mr. Joe Armento, ORNL Chemical Technology Division, Isotopes Facilities Shutdown Program. 
The RmSE of this facility was conducted for LMES under contract by:

Advanced Sciences, Inc.

800 Oak Ridge Turnpike, Suite C-102

Oak Ridge, TN

Tole R. Conar

Evaluator's Signature
$6 / 18 / 96$

Date 


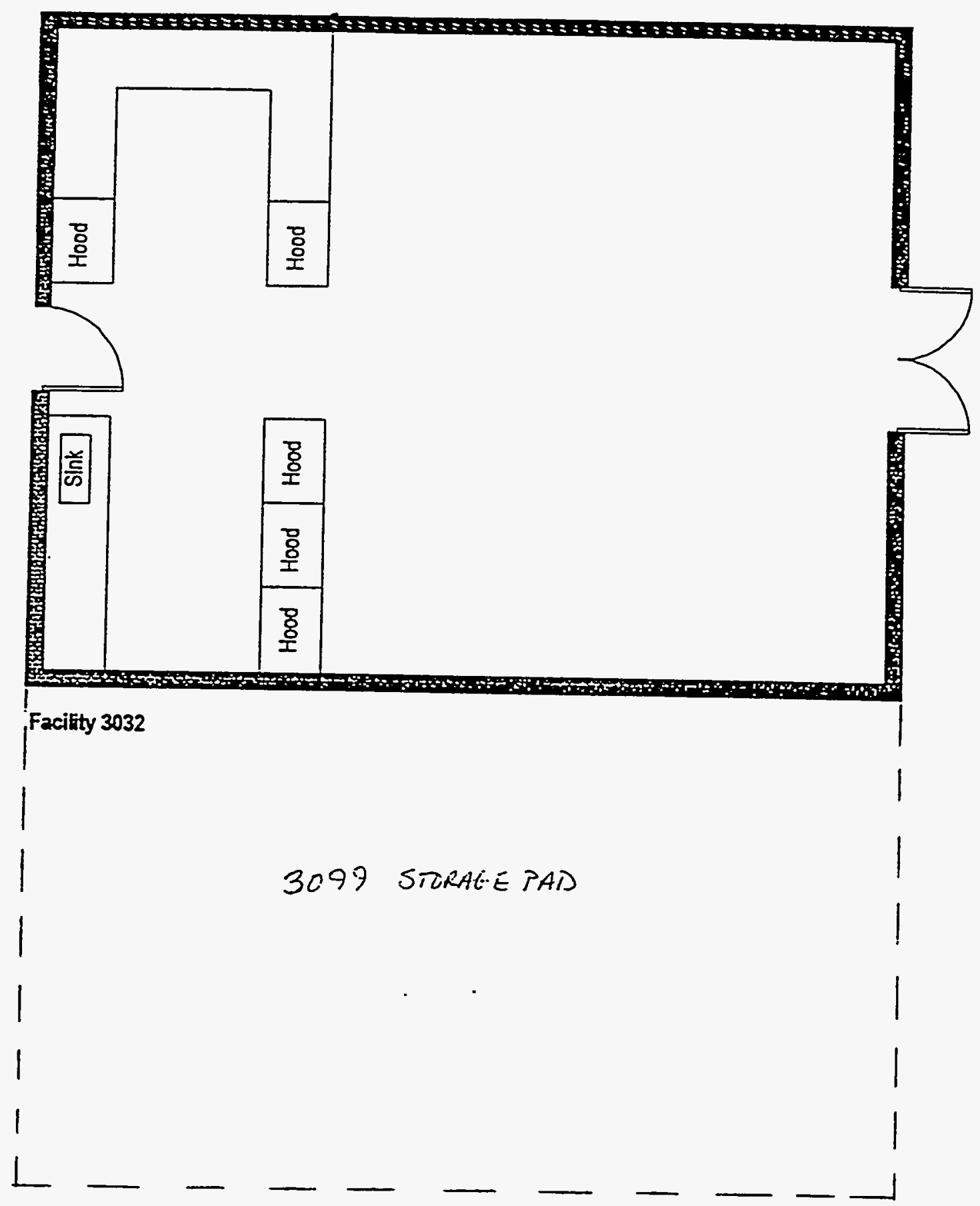

Fig. 9. Diagram of Building 3032/(3099). 
9. BULLING 3033/(3093)— KRYPTON AND TRITIUM FACILITY 

ORNL FACILITY RmSE INFORMATION FORM

\begin{tabular}{|c|c|}
\hline \multicolumn{2}{|c|}{ General Information } \\
\hline $\begin{array}{l}\text { Building } 3033 \text { (Including 3093) } \\
\text { The Krypton and Tritium Facility }\end{array}$ & \\
\hline $\begin{array}{l}\text { Organization responsible for arealfacility } \\
\text { (include specific person and phone number if possible): }\end{array}$ & $\begin{array}{l}\text { R.E. Eversole (576-7483), } \\
\text { IFDP Project Manager, } \\
\text { ER Program, LMES }\end{array}$ \\
\hline Inactive, Standby Mode & Years of Operation: $\approx 40$ \\
\hline $\begin{array}{l}\text { Description of Operation: } \\
\text { There are no current operations, other than surveillance, maint } \\
\text { in this building. Building } 3033 \text { was originally constructed to } \\
\text { that were historically utilized for storage, purification, proc } \\
\text { krypton isotopes (mainly }{ }^{85} \mathrm{Kr} \text { ). Tritium operations involved th } \\
\text { by purification, loading of shipping containers, and shipment } \\
\text { operations included the purification of krypton in preparati } \\
\text { diffusion columns in Building } 3026-\mathrm{C} \text {. Radioisotope processi } \\
\text { enclosures and process hoods. Resulting primary waste strea } \\
\text { processes in this building did not produce liquid process waste }\end{array}$ & $\begin{array}{l}\text { enance, and deactivation activities, on-going } \\
\text { ocess }{ }^{14} \mathrm{C},{ }^{85} \mathrm{Kr} \text {, and }{ }^{3} \mathrm{H} \text {. It contains facilities } \\
\text { essing, and dispensing of tritium }\left({ }^{3} \mathrm{H}\right) \text { and } \\
\text { e receipt of bulk tritium shipments followed } \\
\text { numerous customers worldwide. Krypton } \\
\text { in for direct sale or as feed to the thermal } \\
\text { g and handling was performed in contained } \\
\text { ms included exhausted air. Reportedly, the }\end{array}$ \\
\hline
\end{tabular}

Building 3093 is a permanent krypton storage enclosure located adjacent to Building 3033 to the northwest. For purposes of this report, reference to "the facility" or "the building" includes both Building 3033 and 3093, unless otherwise stated.

Physical description of arealfacility:

- Building 3033 and 3093 are assumed to have been constructed in the late 1940s, based on the documented construction date of surrounding buildings.

- Building 3033 is a single-story, metal framed structure with metal siding. The exterior of the building has been sealed by a polyurethane cocooning process, and it is operated under negative pressure. Building 3093 is a roofless, reinforced-concrete enclosure containing four charcoal-filled storage tanks which are currently empty.

- Building 3033 consists of approximately $1,200 \mathrm{sq} f \mathrm{ft}$ and shares a common wall with Building 3033-A to the east.

- This facility is located in an industrial area of ORNL (Isotopes Circle). The immediate area surrounding the facility is paved for the most part with some grassy areas.

- Building 3033 is basically a single-room laboratory consisting of a krypton processing enclosure, a carbon reactor enclosure, a tritium process room consisting of a number of process hoods, and a utility area. Floor drains in the building discharge to the process system, and the cells drain to the low-level liquid waste (LLLW) system (WC-10). Reportedly, the processes in this building did not generate liquid waste. Work with radioactive materials was performed in the cells and hoods.

- The exterior of the building was observed to be in good condition.

- Generally, the interior of the building is in fair to good condition. Asbestos Containing Material (ACM) and radiation (RAD) hazard areas are posted and/or labeled as appropriate.

- A building space diagram is attached to this form showing the locations of the various process areas and equipment. 


\begin{tabular}{l} 
Release Information \\
\hline Description of release, or threatened release, and source: \\
The only significant area of radioactive contamination in this facility reportedly exists in the form of tritium \\
in three traps and associated equipment (vessels, piping, vent ducts, etc.) in the Tritium Process Room. \\
There are also a few small areas of fixed and transferable radiologic surface contamination located in other \\
areas of the facility. Irretrievable amounts of krypton remain absorbed in the charcoal linings of the krypton \\
storage tanks (Building 3093). Radiologic contamination in this facility has accumulated from activities \\
involving a variety of materials throughout the operating history of the facility and, therefore, cannot be \\
attributed to a single release episode. The existing levels of RAD contamination in the facility are very low \\
and well isolated. The presence of this contamination is not considered a significant hazard in its current \\
state. \\
It is assumed, based on the historical laboratory function of this building and operations in similar facilities, \\
that hazardous materials (HAZMATs) (e.g., acids, hydraulic fluids, and other chemicals) were used in small \\
quantities (i.e., less than 5 gallons or 100 pounds) during facility operations. Reportedly, no HAZMATs \\
are currently used or stored in this facility. According to available spill/release records and facility \\
personnel interviews, no significant HAZMAT spills (i.e., spills having the potential to adversely affect \\
human health and/or the environment) have been reported for this building. No current conditions were \\
identified which present a potential for a HAZMAT release.
\end{tabular}

Hazardous substances present:

Hazardous substances remaining in Building 3033 consist mainly of small amounts of residual fixed and transferable RAD surface contamination $(\beta, \gamma)$. Areas of RAD contamination are associated primarily with the hot cells and tritium process equipment. Reportedly, no HAZMATs are stored or used within this facility.

Estimate (if possible) of quantities of hazardous substances that have been released and that could be released:

The following represents the known quantities of substances currently existing in the facility. Radiologic surface contamination has accumulated from a legacy of many different programs and processes and cannot be attributed to a single release episode. It is only possible to quantify release amounts from contamination which currently exists in the facility and/or has been historically documented from past activities.

$<500 \mathrm{Ci}^{3}{ }^{3} \mathrm{H}$

(Quantity estimate obtained from Building 3033 Hazard Screening Report)

Other pollutants or contaminants:

Asbestos containing material, primarily in the form of thermal system insulation, has been confirmed present in this building. ACM observed is in fair to good condition and poses no immediate health threat. Based on the age of the facility, interior and exterior painted surfaces are assumed to be lead-containing. Verification samples are taken by ORNL Lead Management Program personnel on an "as-needed" basis to confirm the presence of lead in the paint (i.e., when work activities will disturb the paint, or paint is found to be deteriorating and poses a health or environmental threat). Interior painted surfaces observed are in fair to good condition and pose no immediate health threat given the status of this facility. Paint on exterior surfaces was also found to be in good condition, posing no immediate hazard to the surrounding area due to deterioration. 


\section{Groundwater}

Are there any suspected impacts to groundwater? If yes, please describe. Include any impacts to drinking water sources.

Building 3033 is located in Waste Area Grouping 1 at ORNL. Although no specific adverse spills or releases of hazardous substances threatening to groundwater were identified during this RmSE, it is suspected, based on available environmental studies conducted in WAG 1, that process and LLLW drains and associated piping may have leaked over the life of the facilities. Reportedly, processes in Building 3033 did not generate liquid waste; however, since the building is serviced by the LLLW system there is a potential that historically radiologic waste of some sort may have been introduced into the system. Buried process and LLLW piping and some drains have been found to be deteriorated and leaking in other facilities and areas of WAG 1 . Studies have determined that groundwater in WAG 1 has been both radiologically and chemically contaminated. Numerous man-made radionuclides have been detected in WAG 1 groundwater samples. The WAG 1 Site Characterization Report indicates that high levels of tritium have been detected in a monitoring well just south of Building 3033. As a result, it is likely that liquid waste from activities involving radioisotopes in this building have historically contributed to WAG 1 groundwater contamination. However, the radionuclides detected in the groundwater were common to the processes and activities in many other buildings in the area which makes it difficult to determine exactly which building is, or was, the source of contamination.

Because of the small quantities of chemicals assumed to have been used historically used in this facility, it is unlikely that such usage has significantly contributed to WAG 1 groundwater contamination. As part of the facility shutdown process, inactive process and LLLW drains within the building have reportedly been plugged to prevent further release. However, no documentation was available at the time of this report to verify which drains have actually been plugged and which have not. Information on drain locations and discharge points is available from the ORNL Engineering Support Office.

Other than the potential for historical impact to groundwater in WAG 1 via leaking process and LLLW lines external to the building, no existing immediate threat to groundwater was identified given the current status of the facility.

\section{Surface Water}

Are there any suspected impacts to surface water? If yes, please describe. Also describe the most likely surface water migration route(s), if applicable. Include any impacts to drinking water sources.

WAG 1 is essentially bound by Fitth Creek to the east, White Oak Creek (WOC) to the south, and First Creek to the west. First and Fifth creeks flow south into (WOC) which flows to the west and exits WAG 1 at the southwest corner. Storm water (from surface runoff and storm water drainage system) and treated water from the process waste system discharges into WOC. Surface water may have been indirectly impacted by leaking process and LLLW lines external to the building. Some of these lines are known to have shared a common trench with storm water drainage piping. Contamination from leaking waste lines could potentially enter deteriorated storm water piping and migrate to WOC. The three creeks bordering WAG 1 are groundwater discharge points. Therefore, groundwater contaminated by leaking waste lines could also potentially impact surface water in the area.

Additionally, if exterior painted surfaces do, in fact, contain lead, the potential exists for surface water to be impacted from deteriorated paint which washes of the building and finds its way to surface water with the storm water runoff.

Other than the potential for historical impact, no existing immediate threat to surface water was identified given the current status of this facility. 
Air

Are there any suspected impacts due to air emissions? If yes, please describe.

The Hazard Screening Report prepared for Building 3033 indicates that there is no potential for significant radiation exposure to personnel working in or around the facility due to potential airborne migration of radioactive particulates and physical contact with contaminated surfaces. Because of the low levels and nature of RAD contamination within the facilities, potential impacts to persons or the environment surrounding the facilities are considered negligible. Areas of RAD contamination are identified, marked, and controlled as appropriate throughout the facilities to protect against inadvertent exposure to personnel. Air in the building is controlled by the isotopes area cell ventilation system which exhausts building and cell air to stack 3039. This also keeps Building 3033 under slight negative pressure relative to atmosphere. Apart from catastrophic failure of the hot cells, process areas, or ventilation system, it is unlikely that radioactive air emissions from this building would impact personnel or the environment.

There is also a potential for impact to indoor air quality due to the presence of $A C M$ and assumed lead-based paint (LBP) should these materials be disturbed. The ACM and assumed LBP remaining in the building are not considered to be immediate threats to indoor quality in their current state.

\section{Soil}

Are there any suspected impacts to soil? If yes, please describe.

As stated for groundwater, there is a potential for historical impact to soils in the area of Buildings 3033 due to leaking process and LLLW drain piping. Previous environmental studies have identified a soil contamination plume in the Isotopes Circle area and soil samples collected from the plume have detected radioisotopes common to the processes performed in this building (tritium). As a result, it is likely that operations in this facility have historically contributed to the Isotopes Circle soil contamination plume.

There is also a potential for areas of soil adjacent to the facility to be impacted from lead if, in fact, exterior paint is found to be lead-containing. Deteriorating paint could dislodge from the surface and fall to the soil below. The exterior paint was observed to be good condition and does not pose an immediate threat in its current state.

It is unlikely that the small quantities of chemicals assumed to have been used in Building 3033 have significantly impacted soil in the surrounding area.

\section{Release Beyond Facility or Reservation Boundaries}

Has or will the release migrate beyond the boundaries of the facility or reservation? If yes, please describe (including possible human or environmental receptors).

The following are considered potential scenarios where radiologic contamination could migrate beyond the facility or reservation boundaries:

- A person becomes inadvertently contaminated and leaves the facility/reservation undetected.

- Catastrophic failure of hot cells and/or contaminated equipment.

There is also a potential for assumed lead-containing paint which peels off exterior surfaces of the buildings to be carried away with surface runoff during a rain event. Though these potentials exist, they are considered slight and unlikely due to the current status of the facility and the engineering/administrative controls that are in place to protect again such an event. 


\begin{abstract}
Worker Safety
Could the release pose a threat to workers? If yes, please describe.

Radiologically contaminated areas are isolated and well marked. Good radiation practices and standard operating procedures are enforced for worker safety. Personnel exiting the facility are required to "frisk" themselves to detect the presence of RAD contamination. Monitors and alarms are in place to detect any radioactive release within the building. ACM is appropriately labeled. However, even with these safeguards in place, a potential threat to workers exists if safety measures are overlooked. This potential is not considered significant given the current status and level of activity of building.
\end{abstract}

\title{
Environmental Receptors
}

Does the release pose a potential threat to environmental receptors? If yes, please describe. Include natural resources impacts.

No existing conditions posing an immediate significant threat to environmental receptors, including natural resources, were identified to be currently existing or associated with Building 3033.

Mitigation

What action(s) might be taken to abate/prevent release or impacts from release?

- Continued utilization and enforcement of engineering and administrative controls that are currently in place to protect workers and monitor conditions and activities in this building.

- Continue S\&M activities per Procedure IP-900.

What actions are currently being taken to abate/prevent release or impacts from release?

Engineering and administrative controls are in place to control access to contaminated areas and to monitor conditions and activities within the facilities for worker and environmental protection. Warning signs and labels are posted throughout the facilities indicating RAD and ACM hazard areas. Standard operating procedures are in place for building access and surveillance and maintenance activities to protect against inadvertent contact and disturbance of contaminated areas and materials. Radiologically contaminated areas are monitored periodically by ORNL health physics personnel. Personnel are "frisked" upon exit of the facility to detect the presence of radiologic contamination. The building is currently in surveillance and maintenance status awaiting entry into the Decontamination and Decommissioning (D\&D) Program. Inactive waste drains are reportedly plugged in contaminated areas to prevent inadvertent discharge of contamination beyond the facility. A groundwater monitoring program is in place to monitor contamination levels and migration in groundwater underlying WAG 1. The building is inspected for structural changes after each natural incident (earthquake, tornado, or other severe storm), fire and/or man induced activity which could cause cracking, failure, or deterioration of the facility and/or equipment that may allow contamination to be released. No such conditions have been reported for Building 3033 .

Current actions being taken to prevent further release and ensure worker safety in Building 3033 are considered adequate until $\mathrm{D} \& \mathrm{D}$ activities begin.

\section{Other Environmental Authorities}

Is the release or threatened release potentially subject to other environmental statutory actions? If yes, please explain.

If paint is found to be lead-containing and samples fail the Toxicity Characteristic Leaching Procedure (TCLP) analysis, the building could qualify as a hazardous waste generator point under the Resource Conservation and Recovery Act (RCRA). 
Maintenance Actions

Are maintenance actions necessary to eliminate potential threats to human health and the environment? If so, explain.

No existing potential hazards requiring maintenance actions per 40 CFR 300.415 were identified to be currently associated with Building 3033 .

\section{Removal Actions}

Are Removal Actions necessary to eliminate immediate threats to human health and the environment? If so, explain.

No imminent hazards requiring removal actions per 40 CFR 300.415 were identified to be currently associated with Building 3033.

\section{Remedial Site Evaluation}

\section{Is a Remedial Site Evaluation needed?}

Areas of radiologic contamination associated with Building 3033 have been identified and marked as appropriate. However, it is suspected that process and LLLW drains and associated piping may have leaked beneath the slab of the building as a result of past practices. As a result, it is recommended that some type of remedial investigation be performed to assess the condition of the soil in this area before conducting any S\&M or D\&D activities which involve disturbing the slab.

ACM has also been identified, marked and documented. No further remedial investigation involving this hazard is considered necessary given the current status and future plans of this facility.

Based on the age of the facility, painted surfaces are assumed to contain lead. Samples of the paint should be taken and analyzed to verify the presence of lead prior to conducting any S\&M or D\&D activities which may disturb these assumed areas.

\section{No Further Investigation}

Is a finding of No Further Investigation appropriate? Please explain.

A finding of No Further Investigation implies that a facility or area is free from hazardous substances or contaminants that may threaten human health and the environment. Since Building 3033 contains substances and materials which may become threatening if not properly controlled, handled and managed during the S\&M cycle, a finding of No Further Investigation is inappropriate in this case. 


\section{Additional Comments}

The following documents and databases were referenced for historical and hazard information related to Buildings 3033:

- Phase I Safety Documentation, The Krypton and Tritium Facility, Building 3033/3093, Hazard Screening, Document No. HS/3033/3093/F/RT-10/R-1.

- Work Plan for the Isotopes Facilities Deactivation Project at Oak Ridge National Laboratory, Document No. ORNL/ER-249/R2.

- Building 3033 Occurrence Reports, 1989 to present.

- Site Characterization Summary Report for Waste Area Grouping 1 at Oak Ridge National Laboratory, Oak Ridge, Tennessee, Volumes 1 and 2, Document Nos. DOE/OR-1043/VI\&DI and DOE/OR-1043/V2\&D1.

- ORNL Hazardous Material Information System Database.

- ORNL Drain System Survey Report for Building 3033.

The following personnel and offices were contacted and provided historical and current use/condition information for Building 3033:

- Mr. Karl Haff, Radiochemical Processing Department Head, ORNL Radiochemical Technology Section.

- Mr. Herman Phillips, Assistant Facilities Manager, ORNL Special Projects.

- Ms. Swati Wilson, Manager, ORNL Lead Management Program.

- Mr. Nathan Dunn, Hazardous Material Information System Office.

- Mr. Jade Thomas, ORNL Environmental Compliance Office.

- Mr. Joe Armento, ORNL Chemical Technology Division, Isotopes Facilities Shutdown Program.

The RmSE of this facility was conducted for LMES under contract by:

Advanced Sciences, Inc.

800 Oak Ridge Turnpike, Suite C-102

Oak Ridge, TN

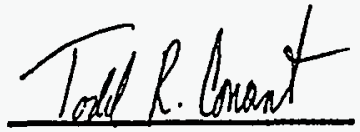

Evaluator's Signature

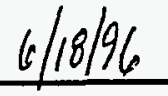

Date 
ORNL DWG 80-500

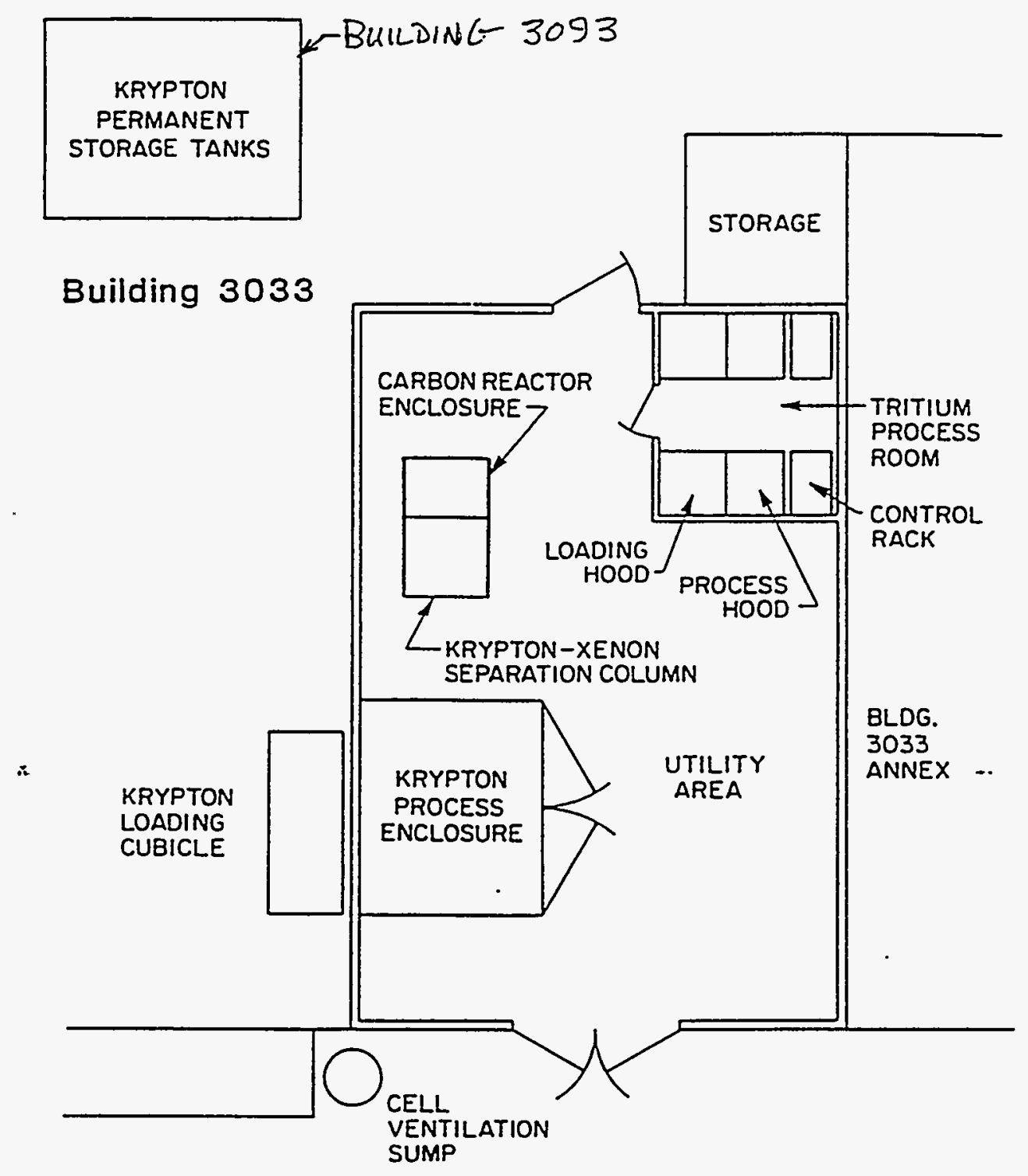

Fig. 10. Diagram of Building 3033/3093. 
ORNL FACILITY RmSE INFORMATION FORM

\begin{tabular}{|c|c|}
\hline \multicolumn{2}{|c|}{ General Information } \\
\hline $\begin{array}{l}\text { Building 3033-A } \\
\text { The Actinide Fabrication Facility }\end{array}$ & \\
\hline $\begin{array}{l}\text { Organization responsible for arealfacility } \\
\text { (include specific person and phone number if possible): } \\
\text { OER Program, LMES }\end{array}$ & $\begin{array}{l}\text { R.E. Eversole (576-7483), } \\
\text { IFDP Project Manager, } \\
\text {. }\end{array}$ \\
\hline Inactive, Standby Mode & Years of Operation: $\approx 30$ \\
\hline $\begin{array}{l}\text { Description of Operation: } \\
\text { There are no current operations, other than surveillance, main } \\
\text { in this building. Building } 3033 \text {-A was used to house and con } \\
\text { welding, and decontamination of neutron dosimeter material } \\
\text { milligram to gram quantities of actinide materials for resear } \\
\text { operating areas; a small area for }{ }^{14} \mathrm{C} \text { production at the south en } \\
\text { area for preparation of research materials. This building } \\
\text { preparation and distribution of highly enriched actinide isot } \\
\text { Program. The following are some of the historical operation } \\
\text { ceramic oxide wires; loading of ceramic oxide wires, oxide p } \\
\text { use as in-core reactor neutron dosimeters; fabrication of m } \\
\text { packaging of milligram to gram quantities of actinide mater } \\
\text { actinide samples for alpha counting; decontamination of nucl } \\
\text { of radioactive materials. Additionally, many other small pr } \\
\text { throughout the years. }\end{array}$ & $\begin{array}{l}\text { enance, and deactivation activities, on-going } \\
\text { ain the facilities for the production, loading, } \\
\text { as well as the weighing and packaging of } \\
\text { h applications. The building included two } \\
\text { of the building, and a larger main operating } \\
\text { has been used almost exclusively for the } \\
\text { ppes, and for a period }{ }^{14} \mathrm{C} \text { for the Isotopes } \\
\text { s performed in this building: fabrication of } \\
\text { wder, or metal into small metal capsules for } \\
\text { noenergetic gamma sources; weighing and } \\
\text { als; preparation of nanogram to milligram } \\
\text { ar material shipping containers; and storage } \\
\text { ojects have been performed in this facility }\end{array}$ \\
\hline
\end{tabular}

Physical description of arealfacility:

- Building 3033-A was constructed in approximately 1960.

- The facility is a single-story, metal framed structure with metal siding. The exterior of the building has been sealed by a polyurethane cocooning process, and the building is operated under negative pressure.

- Building 3033-A consists of approximately $760 \mathrm{sq} \mathrm{ft}$ and shares common walls with Building 3033 to the west and Building 3034 to the east.

- This facility is located in an industrial area of ORNL (Isotopes Circle). The immediate area surrounding the facility is paved for the most part with some grassy areas.

- Building 3033-A is basically a single-room laboratory which consisted of a process hood, glove boxes, and various laboratory equipment. Floor, one hood, and sink drains discharge to the process waste system, and the drain in the hood which was located adjacent to the west wall discharged to the low-level liquid waste (LLLW) system (Tank WC-10). Work with radioactive materials was performed primarily in the hoods and glove boxes. Primary waste streams included exhausted air and liquid process waste.

- The exterior of the building was observed to be in good condition.

- Generally, the interior of the building is in fair to good condition. Asbestos Containing Material (ACM) and radiation (RAD) hazard areas are posted and/or labeled as appropriate. All equipment and hoods have been removed and the building has undergone general decontamination.

- A building space diagram is attached to this form showing the locations of the various process areas and equipment. 


\begin{abstract}
\begin{tabular}{|l|}
\hline Release Information \\
\hline Description of release, or threatened release, and source:
\end{tabular}
No significant areas of radioactive contamination were identified in this facility. Small localized areas of residual fixed and transferable RAD contamination exist in isolated areas throughout the facility; however, this contamination is not considered to represent a significant hazard due to the small amount of material involved. This contamination has accumulated from activities involving a variety of materials throughout the operating history of the facility and, therefore, cannot be attributed to a single release episode. The existing levels of RAD contamination in the facility are very low and well isolated. The presence of this contamination is not considered a significant hazard in its current state.

It is assumed, based on the historical laboratory function of this building and operations in similar facilities, that hazardous materials (HAZMATs) (e.g., acids, hydraulic fluids, and other chemicals) were used in small quantities (i.e., less than 5 gallons or 100 pounds) during facility operations. Reportedly, no HAZMATs are currently used or stored in this facility. According to available spill/release records and facility personnel interviews, no significant HAZMAT spills (i.e., spills having the potential to adversely affect human health and/or the environment) have been reported for this building. No current conditions were identified which present a potential for a HAZMAT release.
\end{abstract}

Hazardous substances present:

Hazardous substances remaining in Building 3033-A consist mainly of small amounts of residual fixed and transferable $\mathrm{RAD}$ surface contamination $(\alpha, \beta / \gamma)$. No significant $\beta / \gamma$ material has been found other than the limited remains of ${ }^{14} \mathrm{C}$ contamination. Areas of RAD contamination are associated primarily with isolated surfaces throughout the facility. Reportedly, no HAZMATs are stored or used within this facility.

Estimate (if possible) of quantities of hazardous substances that have been released and that could be released:

The following represents the known quantities of substances currently existing in the facility. Radiologic surface contamination has accumulated from a legacy of many different programs and processes and cannot be attributed to a single release episode. It is only possible to quantify release amounts from contamination which currently exists in the facility and/or has been historically documented from past activities.

$\approx 1,100 \mu \mathrm{Ci} \alpha$

$\approx 2,160 \mu \mathrm{Ci} \beta / \gamma$

$\approx 72 \mu \mathrm{Ci}{ }^{14} \mathrm{C}$ (located in the ${ }^{14} \mathrm{C}$ storage room)

(Quantity estimates obtained from Building 3033-A Hazard Screening Report)

\title{
Other pollutants or contaminants:
}

Asbestos containing material, primarily in the form of thermal system insulation, has been confirmed present in this building. ACM observed is in fair to good condition and poses no immediate health threat. Based on the age of the facility, interior and exterior painted surfaces are assumed to be lead containing. Verification samples are taken by ORNL Lead Management Program personnel on an "as-needed" basis to confirm the presence of lead in the paint (i.e., when work activities will disturb the paint, or paint is found to be deteriorating and poses a health or environmental threat). Interior painted surfaces observed are in fair to good condition and pose no immediate health threat. Paint on exterior surfaces was also found to be in good condition, posing no immediate hazard to the surrounding area due to deterioration. 


\section{Groundwater}

Are there any suspected impacts to groundwater? If yes, please describe. Include any impacts to drinking water sources.

Building 3033-A is located in Waste Area Grouping 1 at ORNL. Although no specific adverse spills or releases of hazardous substances threatening to groundwater were identified during this RmSE, it is suspected, based on available environmental studies conducted in WAG 1, that process and LLLW drains and associated piping may have leaked over the life of the facilities. Buried process and LLLW piping and some drains have been found to be deteriorated and leaking in other facilities and areas of WAG 1. Studies have determined that groundwater in WAG 1 has been both radiologically and chemically contaminated. Numerous man-made radionuclides common to many of the processes in the Isotopes Facilities have been detected in WAG 1 groundwater samples. As a result, it is possible that liquid waste from activities involving radioisotopes in this building have historically contributed to WAG 1 groundwater contamination. However, the radionuclides detected in the groundwater were common to the processes and activities in many other buildings in the area which makes it difficult to determine exactly which building is, or was, the source of contamination.

Because of the small quantities of chemicals assumed to have been used historically used in this facility, it is unlikely that such usage has significantly contributed to WAG 1 groundwater contamination. As part of the facility shutdown process, inactive process and LLLW drains within the building have reportedly been plugged to prevent further release. However, no documentation was available at the time of this report to verify which drains have actually been plugged and which have not. No Drain Survey Report was available for Building 3033-A.

Other than the potential for historical impact to groundwater in WAG 1 via leaking process and LLLW lines external to the building, no existing immediate threat to groundwater was identified given the current status of the facility.

\section{Surface Water}

Are there any suspected impacts to surface water? If yes, please describe. Also describe the most likely surface water migration route(s), if applicable. Include any impacts to drinking water sources.

WAG 1 is essentially bound by Fifth Creek to the east, White Oak Creek (WOC) to the south, and First Creek to the west. First and Fifth creeks flow south into (WOC) which flows to the west and exits WAG 1 at the southwest corner. Storm water (from surface runoff and storm water drainage system) and treated water from the process waste system discharges into WOC. Surface water may have been indirectly impacted by leaking process and LLLW lines external to the building. Some of these lines are known to have shared a common trench with storm water drainage piping. Contamination from leaking waste lines could potentially enter deteriorated storm water piping and migrate to WOC. The three creeks bordering WAG 1 are groundwater discharge points. Therefore, groundwater contaminated by leaking waste lines could also potentially impact surface water in the area.

Additionally, if exterior painted surfaces do, in fact, contain lead, the potential exists for surface water to be impacted from deteriorated paint which washes of the building and finds its way to surface water with the storm water runoff.

Other than the potential for historical impact, no existing immediate threat to surface water was identified given the current status of this facility. 
Air

Are there any suspected impacts due to air emissions? If yes, please describe.

The Hazard Screening Report prepared for Building 3033-A indicates that there is no potential for significant radiation exposure to personnel working in or around the facility due to potential airborne migration of radioactive particulates and physical contact with contaminated surfaces. Because of the low levels and nature of RAD contamination within the facilities, potential impacts to persons or the environment surrounding the facilities are considered negligible. Areas of RAD contamination are identified, marked, and controlled as appropriate throughout the facilities to protect against inadvertent exposure to personnel. Air within the building is controlled by the isotopes area cell ventilation system which exhausts building air to stack 3039 after passing through local roughing and high efficiency particulate air (HEPA) filters inside the building. This also keeps Building 3033-A under slight negative pressure relative to atmosphere. Apart from catastrophic failure of the structure or ventilation system, it is unlikely that radioactive air emissions from this building would impact personnel or the environment.

There is also a potential for impact to indoor air quality due to the presence of ACM and assumed lead-based paint (LBP) should these materials be disturbed. The ACM and assumed LBP remaining in the building are not considered to be immediate threats to indoor quality in their current state.

Soil

Are there any suspected impacts to soil? Ifyes, please describe.

As stated for groundwater, there is a potential for historical impact to soils in the area of Building 3033-A due to leaking process and LLLW drain piping. Previous environmental studies have identified a soil contamination plume in the Isotopes Circle area and soil samples collected from the plume have detected radioisotopes common to many of the processes performed in the Isotopes Facilities. As a result, it is possible that operations in this facility have historically contributed to the Isotopes Circle soil contamination plume.

There is also a potential for areas of soil adjacent to the facility to be impacted from lead if, in fact, exterior paint is found to be lead-containing. Deteriorating paint could dislodge from the surface and fall to the soil below. The exterior paint was observed to be good condition and does not pose an immediate threat in its current state.

It is unlikely that the small quantities of chemicals assumed to have been used in Building 3033-A have significantly impacted soil in the surrounding area.

\section{Release Beyond Facility or Reservation Boundaries}

Has or will the release migrate beyond the boundaries of the facility or reservation? If yes, please describe (including possible human or environmental receptors).

The following are considered potential scenarios where radiologic contamination could migrate beyond the facility or reservation boundaries:

- A person becomes inadvertently contaminated and leaves the facility/reservation undetected.

- Catastrophic failure of the structure and/or contaminated equipment. 
Has or will the release migrate beyond the boundaries of the facility or reservation? Ifyes, please describe (including possible human or environmental receptors). (Continued)

There is also a potential for assumed lead-containing paint which peels off exterior surfaces of the buildings to be carried away with surface runoff during a rain event. Though these potentials exist, they are considered slight and unlikely due to the current status of the facility and the engineering/administrative controls that are in place to protect again such an event.

\section{Worker Safety}

Could the release pose a threat to workers? If yes, please describe.

Radiologically contaminated areas are isolated and well marked. Good radiation practices and standard operating procedures are enforced for worker safety. Personnel exiting the facility are required to "frisk" themselves to detect the presence of RAD contamination. ACM is appropriately labeled. However, even with these safeguards in place, a potential threat to workers exists if safety measures are overlooked. This potential is not considered significant given the current status and level of activity of this building.

\section{Environmental Receptors}

Does the release pose a potential threat to environmental receptors? If yes, please describe. Include natural resources impacts.

No existing conditions posing an immediate significant threat to environmental receptors, including natural resources, were identified to be currently existing or associated with Building 3033-A.

Mitigation

What action(s) might be taken to abate/prevent release or impacts from release?

- Continued utilization and enforcement of engineering and administrative controls that are currently in place to protect workers and monitor conditions and activities in these buildings.

- Continue S\&M activities per Procedure IP-900.

\section{What actions are currently being taken to abate/prevent release or impacts from release?}

Engineering and administrative controls are in place to control access to contaminated areas and to monitor conditions and activities within the facilities for worker and environmental protection. Warning signs and labels are posted throughout the facilities indicating RAD and ACM hazard areas. Standard operating procedures are in place for building access and surveillance and maintenance activities to protect against inadvertent contact and disturbance of contaminated areas and materials. Radiologically contaminated areas are monitored periodically by ORNL health physics personnel. Personnel are "frisked" upon exit of the facility to detect the presence of radiologic contamination. The building is currently in surveillance and maintenance status awaiting entry into the Decontamination and Decommissioning (D\&D) Program. Inactive waste drains are reportedly plugged in contaminated areas to prevent inadvertent discharge of contamination beyond the facility. A groundwater monitoring program is in place to monitor contamination levels and migration in groundwater underlying WAG 1. The building is inspected for structural changes after each natural incident (earthquake, tornado, or other severe storm), fire and/or man induced activity which could cause cracking, failure, or deterioration of the facility and/or equipment that may allow contamination to be released. No such conditions have been reported for Building 3033-A.

Current actions being taken to prevent further release and ensure worker safety in Building 3033-A are considered adequate until $\mathrm{D} \& \mathrm{D}$ activities begin. 


\section{Other Environmental Authorities}

Is the release or threatened release potentially subject to other environmental statutory actions? If yes, please explain.

If paint is found to be lead-containing and samples fail the Toxicity Characteristic Leaching Procedure (TCLP) analysis, the building could qualify as a hazardous waste generator point under the Resource Conservation and Recovery Act (RCRA).

\section{Maintenance Actions}

Are maintenance actions necessary to eliminate potential threats to human health and the environment? If so, explain.

No existing potential hazards requiring maintenance actions were identified to be associated with Building 3033-A.

\section{Removal Actions}

Are Removal Actions necessary to eliminate immediate threats to human health and the environment? If so, explain.

No imminent hazards requiring removal actions per $40 C F R$ ' 300.415 were identified to be currently associated with Building 3033-A.

\section{Remedial Site Evaluation}

\section{Is a Remedial Site Evaluation needed?}

Areas of radiologic contamination associated with Building 3033-A have been identified and marked as appropriate. However, it is suspected that process and LLLW drains and associated piping may have leaked beneath the slab of the building as a result of past practices. As a result, it is recommended that some type of remedial investigation be performed to assess the condition of the soil in this area before conducting any S\&M or D\&D activities which involve disturbing the slab.

$\mathrm{ACM}$ has also been identified, marked and documented. No further remedial investigation involving this hazard is considered necessary given the current status and future plans of this facility.

Based on the age of the facility, painted surfaces are assumed to contain lead. Samples of the paint should be taken and analyzed to verify the presence of lead prior to conducting any S\&M or D\&D activities which may disturb these assumed areas.

\section{No Further Investigation}

\section{Is a finding of No Further Investigation appropriate? Please explain.}

A finding of No Further Investigation implies that a facility or area is free from hazardous substances or contaminants that may threaten human health and the environment. Since Building 3033-A contains substances and materials which may become threatening if not properly controlled, handled and managed during the S\&M cycle, a finding of No Further Investigation is inappropriate in this case. 


\section{Additional Comments}

The following documents and databases were referenced for historical and hazard information related to Building 3033-A:

- Phase I Safety Documentation, The Actinide Fabrication Facility, Building 3033-A, Hazard Screening, Document No. HS/3033-A/3093/F/RT-11(Rev.1).

- Work Plan for the Isotopes Facilities Deactivation Project at Oak Ridge National Laboratory, Document No. ORNL/ER-249/R2.

- Building 3033-A Occurrence Reports, 1989 to present.

- Site Characterization Summary Report for Waste Area Grouping 1 at Oak Ridge National Laboratory, Oak Ridge, Tennessee, Volumes 1 and 2, Document Nos. DOE/OR-1043/V1\&D1 and DOE/OR-1043/V2\&D1.

- ORNL Hazardous Material Information System Database.

- ORNL Drain System Survey Report for Buildings 3030, 3031, and 3118.

The following personnel and offices were contacted and provided historical and current use/condition information for Building 3033-A:

- Mr. Karl Haff, Radiochemical Processing Department Head, ORNL Radiochemical Technology Section.

- Mr. Herman Phillips, Assistant Facilities Manager, ORNL Special Projects.

- Ms. Swati Wilson, Manager, ORNL Lead Management Program.

- Mr. Nathan Dunn, Hazardous Material Information System Office.

- Mr. Jade Thomas, ORNL Environmental Compliance Office.

- Mr. Joe Armento, ORNL Chemical Technology Division, Isotopes Facilities Shutdown Program.

The RmSE of this facility was conducted for LMES under contract by:

Advanced Sciences, Inc.

800 Oak Ridge Turnpike, Suite C-102

Oak Ridge, TN

Tode l. Conant

Evaluator's Signature

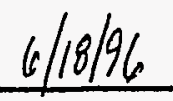

Date 


\section{Building 3033-A}

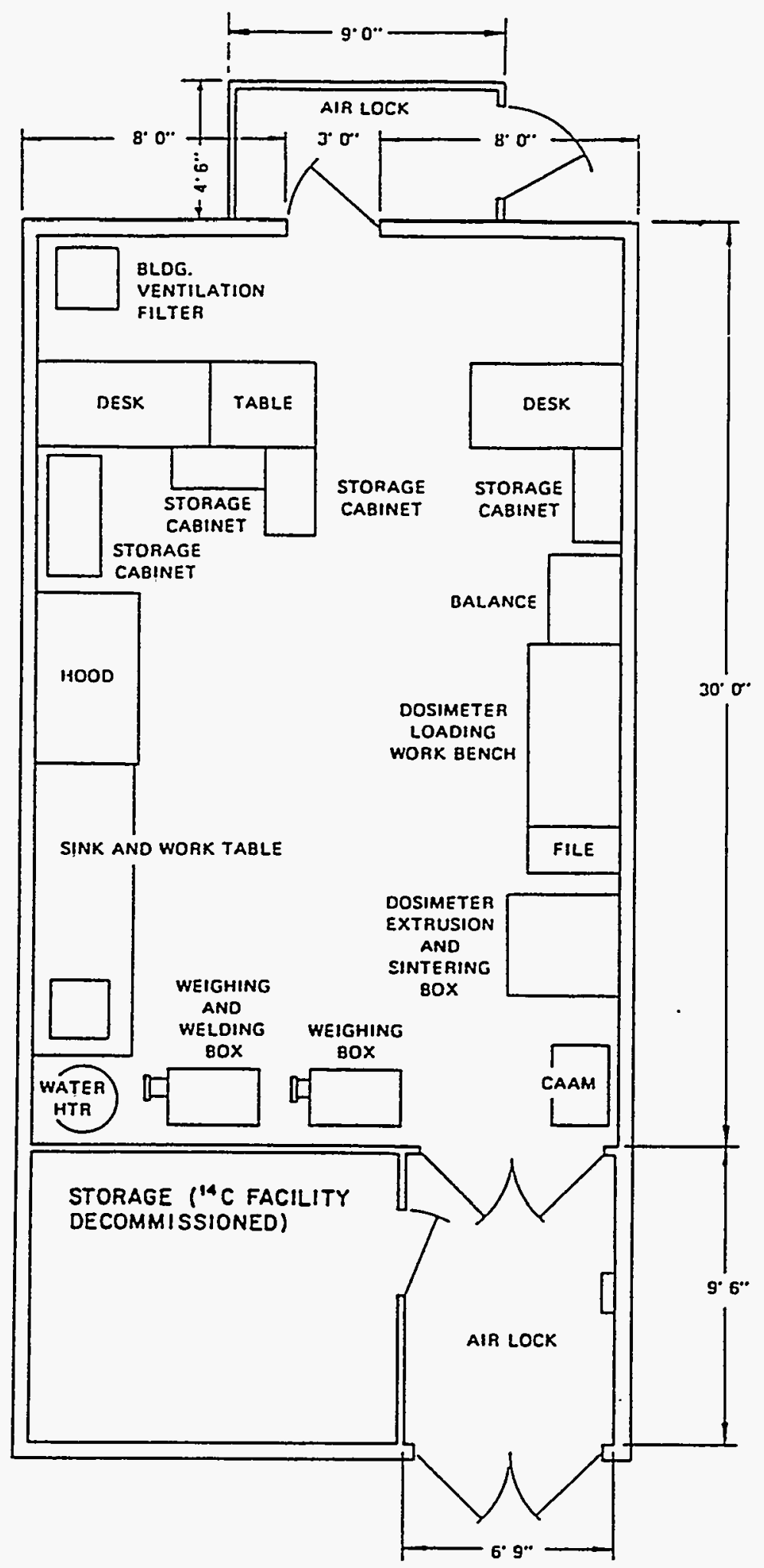

Fig. 11. Diagram of Building 3033-A. 
11. BUILDING 3034-RADIOISOTOPE AREA SERVICES BUILDING 

ORNL FACILITY RmSE INFORMATION FORM

\begin{tabular}{|l|l|}
\hline \multicolumn{2}{|c|}{ General Information } \\
\hline $\begin{array}{l}\text { Area/Facility Name } \\
\text { (and aliases): }\end{array}$ & $\begin{array}{l}\text { Building } 3034 \\
\text { Radioisotope Area Services Building }\end{array}$ \\
\hline $\begin{array}{l}\text { Organization responsible for area/facility } \\
\text { (include specific person and phone number if possible): }\end{array}$ & \multicolumn{2}{|c|}{ R.E. Eversole (576-7483), } \\
IFDP Project Manager, \\
ER Program, LMES
\end{tabular}

Physical description of arealfacility:

- Building 3034 was originally constructed in the 1950 s.

- The building is a single-story, metal framed structure with metal siding consisting of approximately 1,400 sq. $\mathrm{ft}$. of floor space. The building is not sealed by polyurethane cocooning. Paint observed on exterior surfaces is in good condition.

- Building 3034 is located in an industrial area of ORNL (Isotopes Circle). The immediate area surrounding the facilities is paved for the most part with some grassy areas. The building shares a common wall with Building 3033-A to the west.

- The building consists of offices and a small warehouse area containing the electrical distribution station. Floor drains in the building reportedly discharge to the process waste system. Low-level liquid waste (LLLW) service has never been available in this building. Reportedly, no work associated with radioactive materials has been performed in this building. Information on drain locations and discharge points is available from the ORNL Engineering Support Office.

- Generally, the interior of the building is in good condition. Asbestos Containing Material (ACM) is labeled as appropriate. No polychlorinated bi-phenols (PCBs) were identified to be associated with this building.

- Building 3034 is operated under normal atmospheric pressure.

- A building space diagram is attached to this form showing the layout of the facility.

\section{Release Information}

Description of release, or threatened release, and source:

Despite the fact that no radioactive materials were reportedly handled in this facility (according to the IFDP Work Plan and facility personnel), the Hazard Screening report for the facility indicates that some small, fixed hot spots of residual radioactive surface contamination remain in inaccessible areas. 
Description of release, or threatened release, and source: (Continued)

Perimeter walls within the facility have been decontaminated to a level of ten feet above the floor. The wall area above this point is presently identified as a fixed radiologic contamination area by postings. Since there is no record of radioactive material handling in this facility, the origin of this release and remaining contamination is uncertain. The remaining contamination is in small enough quantity to be considered insignificant.

It is assumed, based on the historical shop function of this building, that hazardous materials (HAZMATs) (e.g., acids, hydraulic fluids, and other chemicals) were used in small quantities (i.e., less than 5 gallons or 100 pounds) during facility operations. According to available spill/release records and facility personnel interviews, no significant HAZMAT spills (i.e., spills having the potential to adversely affect human health and/or the environment) have been reported for this building. No current conditions were identified which present a potential for a HAZMAT release.

Hazardous substances present:

Hazardous substances remaining in Building 3034 consist mainly of small amounts of residual fixed RAD surface contamination $(\beta / \gamma)$ and larger quantities of HAZMATs. Areas of fixed RAD contamination are associated with the interior perimeter wall surfaces above the ten-foot level. Because of the renovation work on-going in this building, a number of HAZMATs exist in this facility in various quantities. These materials are listed on the attached HAZMAT inventory sheets. No PCBs were identified to be present in within the building.

Estimate (if possible) of quantities of hazardous substances that have been released and that could be released:

The following represents the known quantities of substances currently existing in the facility. Since there has been no documented historical use of radioactive materials in this facility, it is uncertain where this contamination originated from. It is only possible to quantify release amounts from contamination which currently exists in the facility and/or has been historically documented from past activities.

$<1,700 \mu \mathrm{Ci} \beta / \gamma$

4,875 lbs HAZMATs (see attached HAZMAT sheet for detailed quantity breakdown).

(Quantity estimates obtained from Building 3034 Hazard Screening Report and ORNL Hazardous Material Information System database)

\section{Other pollutants or contaminants:}

Asbestos containing material, primarily in the form of thermal system insulation, has been confirmed present in this building. ACM observed is in fair to good condition and poses no immediate health threat. Based on the age of the facility, interior and exterior painted surfaces are assumed to be lead-containing. Verification samples are taken by ORNL Lead Management Program personnel on an "as-needed" basis to confirm the presence of lead in the paint (i.e., when work activities will disturb the paint, or paint is found to be deteriorating and poses a health or environmental threat). Interior painted surfaces observed are in good condition and pose no immediate health threat. Paint on exterior surfaces was also found to be in good condition, posing no immediate hazard to the surrounding area due to deterioration. There is, however, an area of deteriorating exterior paint on exposed piping adjacent to the east wall of the building which should be noted. Though this piping is not specific to Building 3034, it is peeling off and paint chips can be seen laying in the grassy area adjacent to the east side of the building. 


\section{Groundwater}

Are there any suspected impacts to groundwater? If yes, please describe. Include any impacts to drinking water sources.

Building 3034 is located in Waste Area Grouping 1 at ORNL. Based on the information available regarding current and historical usage and operation of this facility, there is no reasonable evidence to suggest Building $\mathbf{3 0 3 4}$ has significantly impacted groundwater in the area in any way.

Because of the depth to groundwater in the area of building 3034, soil characteristics, and nature and extent of potential lead-based paint (LBP) contamination, it is unlikely that lead from the paint chipping off of the exterior piping adjacent to the east side of the building has impacted groundwater through vertical migration if, in fact, the paint actually contains lead.

\section{Surface Water}

Are there any suspected impacts to surface water? If yes, please describe. Also describe the most likely surface water migration route(s), if applicable. Include any impacts to drinking water sources.

The only identified potential for impact to surface water from Building 3034 was the exterior painted surfaces and piping adjacent to the building if, in fact, the paint does contain lead. The potential exits for paint which has chipped off the building or piping to finds its way to surface water with the storm water runoff during a rain event. Numerous paint chips were observed in the grassy area adjacent to the east side of the building. This area runs alone the side of the building, is approximately three feet wide, and slopes toward the pavement between Buildings 3034 and 3036. As a result, it is highly likely that a hard downpour could float the chips and carry them to the nearest storm drain.

Other than the potential for assumed lead paint impact, no existing immediate threat to surface water was identified given the current status of this facility.

\section{Air}

Are there any suspected impacts due to air emissions? If yes, please describe.

The Hazard Screening Report prepared for Building 3034 indicates that there is no potential for significant radiation exposure to personnel working in or around this facility as a result of airborne migration of radioactive particulates and physical contact with contaminated surfaces. Areas of RAD contamination are identified and marked within the facility to protect against inadvertent exposure to personnel. Air within the building is controlled by a local ventilation system. Because of the small amounts of RAD contamination present, it is highly unlikely that radioactive air emissions from this building would impact personnel or the environment.

There is, however, a potential for impact to indoor air quality due to the presence of ACM, assumed LBP, and usage of HAZMATs. ACM and lead-based paint pose a potential threat should these materials be disturbed and become airborne. Certain HAZMATs can pose a potential threat to indoor air quality if the area they are used in is not adequately ventilated. The ACM, assumed LBP, and HAZMATs remaining in the building are not considered to be immediate threats to indoor quality in their current state.

\section{Soil}

Are there any suspected impacts to soil? If yes, please describe.

Based on the information available regarding historical usage and operation of this facility, there is no reasonable evidence to suggest Building 3034 has significantly impacted the soil below the building or in the immediate area in any way. Therefore, it is unlikely that activities in this building have contributed to the Isotopes Circle soil contamination plume identified in the Site Characterization Report for WAG 1.

Paint chips from the exterior piping adjacent to the east side of the building were observed in the grassy area below the piping. If the paint contains lead, there is a potential for lead impact to the soil in this area. 
What actions are currently being taken to abate/prevent release or impacts from release?

Administrative controls are in place to control access to contaminated areas and to monitor conditions and activities within the facility for worker and environmental protection. Warning tape and labels are used to identify RAD and ACM hazard areas. Standard operating procedures are in place for building access and surveillance and maintenance activities to protect against inadvertent contact and disturbance of contaminated areas. Radiologically contaminated areas are monitored periodically by ORNL health physics personnel. The building is currently in surveillance and maintenance status awaiting usage as storage and office space and subsequent entry into the Decontamination and Decommissioning (D\&D) Program. A groundwater monitoring program is in place to monitor contamination levels and migration in groundwater underlying WAG 1. The building is inspected for structural changes after each natural incident (earthquake, tornado, or other severe storm), fire and/or man induced activity which could cause cracking, failure, or deterioration of the facility and/or equipment that may allow contamination to be released. No such conditions have been reported for Building 3034.

Current actions being taken to prevent further release and ensure worker safety in Building 3034 are considered adequate until D\&D activities begin.

\begin{tabular}{l} 
Other Environmental Authorities \\
\hline $\begin{array}{l}\text { Is the release or threatened release potentially subject to other environmental statutory actions? If yes, } \\
\text { please explain. }\end{array}$
\end{tabular}

If paint is found to be lead-containing and samples fail the Toxicity Characteristic Leaching Procedure (TCLP) analysis, the building could qualify as a hazardous waste generator point under the Resource Conservation and Recovery Act (RCRA).

\section{Maintenance Actions}

Are maintenance actions necessary to eliminate potential threats to human health and the environment? If so, explain.

Samples should be taken of the exterior paint located on the piping adjacent to the east wall of the facility. The samples should then be analyzed to determine whether the paint does, in fact, contain lead. Such analysis should include TCLP (40 CFR 261, Appendix II) to determine whether the area qualifies as a RCRA generator point. If the paint is found to contain lead, abatement actions will be required to prevent deteriorated areas of paint from dislodging and falling to the ground below, potentially having a direct impact on soil in this area, and an indirect impact to surface water.

No further potential hazards requiring maintenance actions were identified to be associated with Building 3034.

\section{Removal Actions}

Are Removal Actions necessary to eliminate immediate threats to human health and the environment? If so, explain.

No imminent hazards requiring removal actions per 40 CFR 300.415 were identified to be currently associated with Building 3034 . 


\section{Remedial Site Evaluation}

\section{Is a Remedial Site Evaluation needed?}

Pending confirmatory sampling and analysis results of the paint on exterior piping adjacent to the east wall of the facility, a remedial site evaluation (RSE) should be conducted to determine whether the soil in this area has been impacted by lead from chipping paint and whether remediation of the soil is necessary.

Although no reasonable evidence was identified during this RmSE to suggest that Building 3034 has contributed to soil contamination in the area, it is possible that soil beneath the slab of this building may have been impacted from migration of contamination originating from leaking process and/or LLLW piping in the area. As a result, it is recommended that some type of remedial investigation be performed to assess the condition of the soil in this area before conducting any $S \& M$ or D\&D activities which involve disturbing the slab.

ACM has also been identified, marked and documented. No further remedial investigation involving this hazards is considered necessary given the current status and future plans of this facility.

Based on the age of the facility, painted surfaces are assumed to contain lead. Samples of the paint should be taken and analyzed to verify the presence of lead prior to conducting any $S \& M$ or D\&D activities which may disturb these assumed areas.

\section{No Further Investigation}

Is a finding of No Further Investigation appropriate? Please explain.

A finding of No Further Investigation implies that a facility or area is free from hazardous substances or contaminants that may threaten human health and the environment. Since Building 3034 contains substances and materials which may become threatening if not properly controlled, handled and managed during the S\&M cycle, a finding of No Further Investigation is inappropriate in this case.

\section{Additional Comments}

The following documents and databases were referenced for historical and hazard information related to Building 3034:

- Phase I Safety Documentation, Radioisotopes Area Services Building, Building 3034 Hazard Screening, Document No. HS/3034/F/RT-12 (Rev.0).

- Work Plan for the Isotopes Facilities Deactivation Project at Oak Ridge National Laboratory, Document No. ORNL/ER-249/R2.

- Available Building 3034 Occurrence Reports, 1989 to present.

- Site Characterization Summary Report for Waste Area Grouping 1 at Oak Ridge National Laboratory, Oak Ridge, Tennessee, Volumes 1 and 2, Document Nos. DOE/OR-1043/V1\&D1 and DOE/OR-1043/V2\&D1.

- ORNL Hazardous Material Information System Database.

- ORNL Drain System Survey Report for Building 3034.

The following personnel and offices were contacted and provided historical and current use/condition information for Building 3034:

- Mr. Karl Haff, Radiochemical Processing Department Head, ORNL Radiochemical Technology Section.

- Ms. Swati Wilson, Manager, ORNL Lead Management Program.

- Mr. Nathan Dunn, Hazardous Material Information System Office.

- Mr. Jade Thomas, ORNL Environmental Compliance Office.

- Mr. Joe Armento, ORNL Chemical Technology Division, Isotopes Facilities Shutdown Program. 


\section{$11-9$}

The RmSE of this facility was conducted for LMES under contract by:

Advanced Sciences, Inc.

800 Oak Ridge Turnpike, Suite C-102

Oak Ridge, TN

Toder. Conant

Evaluator's Signature
$6 / 18 / 96$

Date 


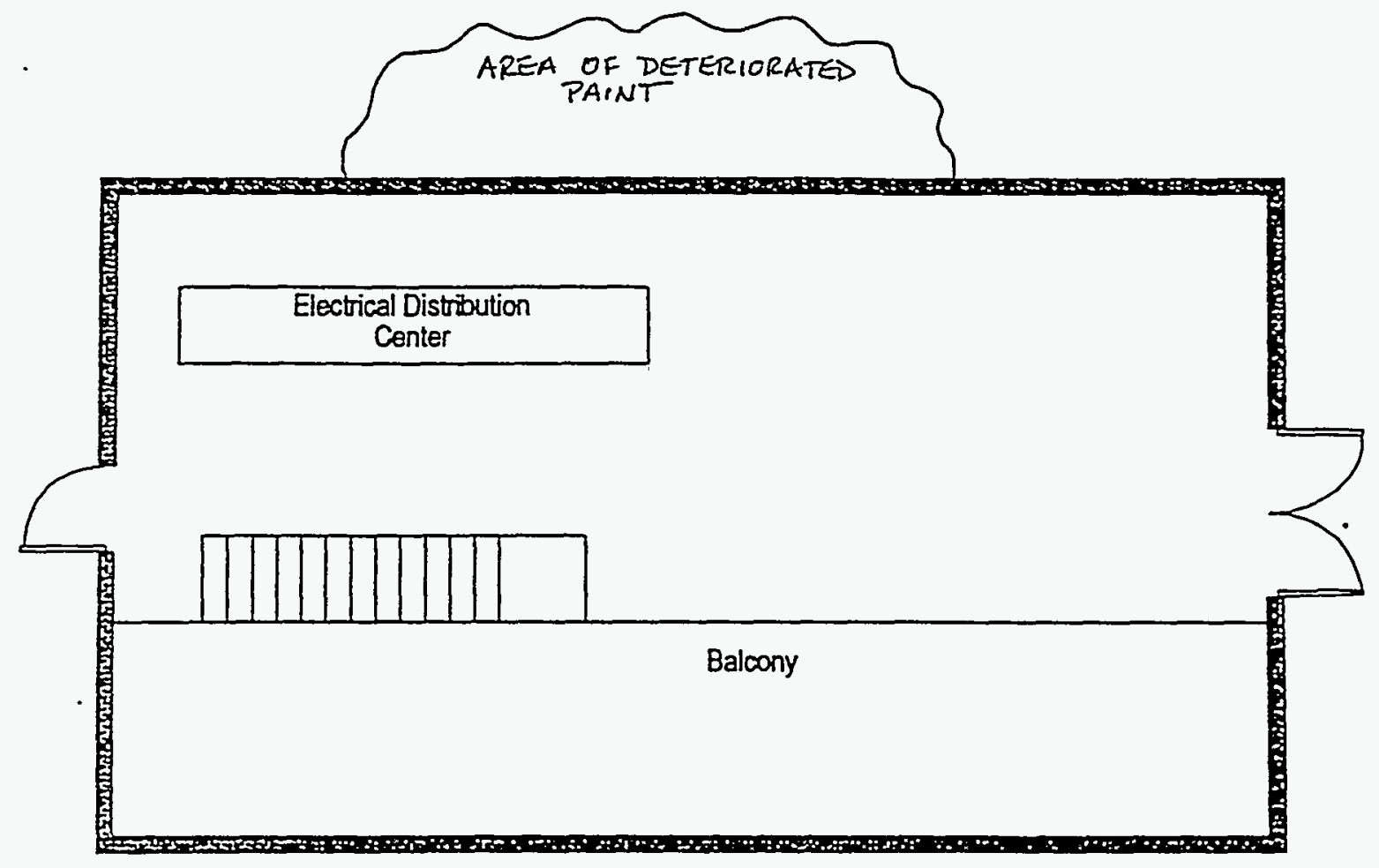

Fig. 12. Diagram of Building 3034. 
Plant: 3

Department:

Control Area:

Room: Area:

WA Code:

Date Expiration: Inv status: MSDS Avail: Haz Mat Grp Cd: ${ }^{\text {Io }}$ Phy state:

Cont Type cd:

Building: 3034

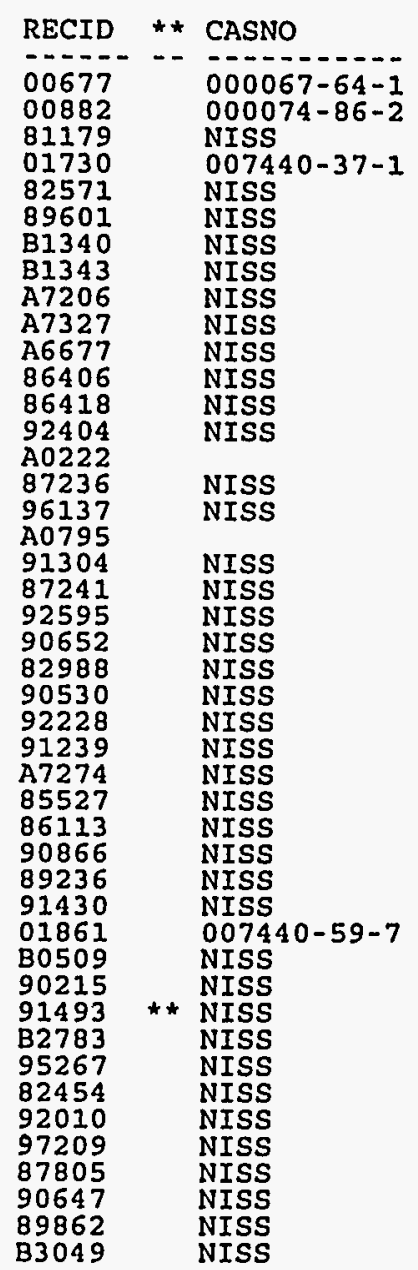

Material Name

ACETONE ACETYLENE
AJAX INSTITUTIONAL CLEANSER WITH OXYGEN BLEACH

ASHLAND PLIOBOND 20

AELT DRESSING \#439-3490

STYLE 264 MOR SHEET

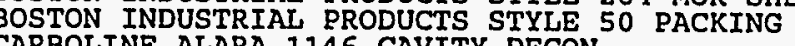

COTING

CARBOLINE ALARA 1146 CATRIPPABLE COATING

CINCINNATI MILICRON CIMTAP(R)

COPPERMATE PASTE SOLDERING FLUX

DEVCON 5-MINUTE EPOXY HARDENER (91081) AND RESIN(90

DEVCON PLASTIC STEEL PUTTY (A) RESIN

DEVOE WONDER SHIELD EXTERIOR ACRYLIC LATEX SATIN

DEXTER EPOXI-PATCH KIT 615, PART A (88069) AND PAR

DOW CORNING SILICONE PLUS (IM) TREM $100 \%$ SIL SLNT,

DOW CORNING(R) HIGH VACUUM GREASE

EXXON KUTWELL 400

EXXON TERESSTIC 33

FEL-PRO C5-A HIGH TEMPERATURE ANTISEIZE COMPOUND

FEL-PRO CLOVER SILICON CARBIDE GREASE MIX

GARLOCK LUBAL

GARLOCK STYLE HTC-9800 COMPRESSED CARBON FIBER SHE

GAVLON 510 ENAMEL ANY COLOR

GE SILICONE RUBBER SEALANT SCS2004

GE SILICONE SEALANT GE5090

GLYPTAL 1202 WHTTE FLUX, SILVER BRAZTNG FLUX' HANDY \&

HERCULES PVC CEMENT CLEAR MEDIUM

HERCULES STA-PUT ( $R$ )

INSTA-FOAM OZONE FRIENDLY GREAT STUF

ITW FLUID PRODUCTS GROUP TOLE STEEL BLUE DX-100

JOHNSON COMPLETE FOR FLOORS

JOHNSON FORTIFY

JOHNSON

JOHNSON WAX FINISH JX-4000/CONCRETE SEALER

$K \& W$ KNOCKER LOOSE

KEL-SAN SUPER DRAIN OPENER

KULITE TUNGSTEN HEAVY METAL ALLOY (POWDER/METAL)

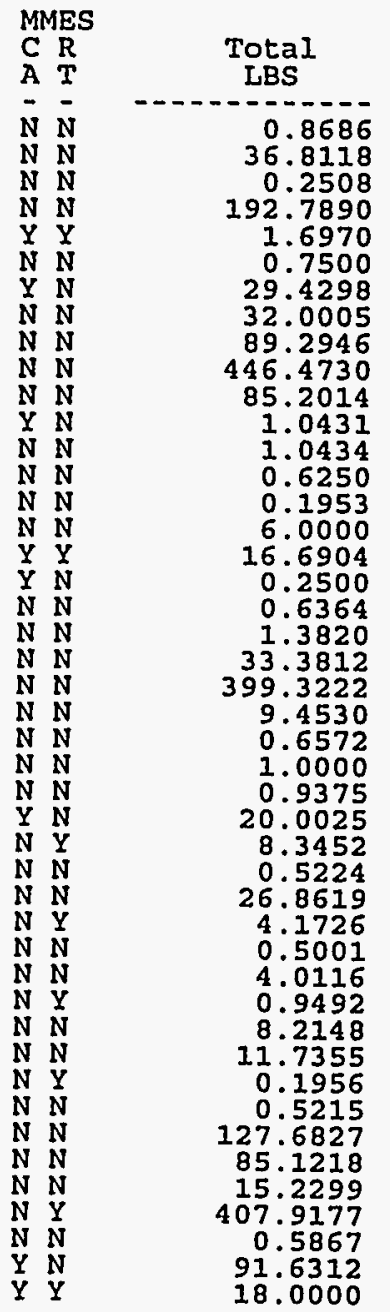

\begin{tabular}{r} 
Total \\
KILOGRAMS \\
\hline 0.3940 \\
16.6976 \\
0.1136 \\
87.4482 \\
0.7700 \\
0.3401 \\
13.3491 \\
14.5153 \\
40.5037 \\
202.5180 \\
38.6444 \\
0.4731 \\
0.4733 \\
0.2840 \\
0.0885 \\
2.7210 \\
7.5706 \\
0.1136 \\
0.2888 \\
0.6268 \\
15.1416 \\
181.1313 \\
4.2880 \\
0.2980 \\
0.4535 \\
0.4252 \\
9.0731 \\
3.7853 \\
0.2368 \\
12.1844 \\
1.8926 \\
0.2268 \\
1.8196 \\
0.4305 \\
3.7260 \\
5.3230 \\
0.0888 \\
0.2365 \\
57.9165 \\
38.6110 \\
6.9079 \\
185.0296 \\
0.2661 \\
41.5636 \\
8.1646 \\
\end{tabular}

* indicates MSDS is not available 
Plant: 3 Division: Item ID:

Date Expiration:

\begin{tabular}{|c|c|c|}
\hline $\begin{array}{l}86128 \\
\text { B2687 } \\
92594 \\
82754 \\
82732 \\
90716 \\
94789 \\
82539 \\
91411 \\
91282 \\
01133 \\
89735 \\
A 6607 \\
\text { A5769 } \\
\text { A9857 } \\
94841 \\
\text { A0744 } \\
89201 \\
89353 \\
88524 \\
A 2302 \\
B 1963 \\
A 4587 \\
A 7641 \\
\text { A7342 } \\
\text { B1863 } \\
88744 \\
92397 \\
91410 \\
85567 \\
A 2940 \\
91048 \\
90980 \\
\text { B2875 } \\
\text { A5857 } \\
06410 \\
\text { A9818 } \\
95324 \\
89521 \\
85489 \\
89871 \\
94192 \\
82913 \\
82672 \\
89356 \\
89768\end{array}$ & $\star \star$ & $\begin{array}{l}\text { NISS } \\
\text { NISS } \\
\text { NISS } \\
\text { NISS } \\
\text { NISS } \\
\text { NISS } \\
\text { NISS } \\
\text { NISS } \\
\text { NISS } \\
\text { NISS } \\
007782-44-7 \\
\text { NISS } \\
\text { NISS } \\
\text { NISS } \\
\text { NISS } \\
\text { NISS } \\
\text { NISS } \\
\text { NISS } \\
\text { NISS } \\
\text { NISS } \\
\text { NISS } \\
\text { NISS } \\
\text { NISS } \\
\text { NISS } \\
\text { NISS } \\
\text { NISS } \\
\text { NISS } \\
\text { NISS } \\
\text { NISS } \\
\text { NISS } \\
\text { NISS } \\
\text { NISS } \\
\text { NISS } \\
\text { NISS } \\
\text { NISS } \\
007681-52-9 \\
\text { NISS } \\
\text { NISS } \\
\text { NISS } \\
\text { NISS } \\
\text { NISS } \\
\text { NISS } \\
\text { NISS } \\
\text { NISS } \\
\text { NISS } \\
\text { NISS } \\
\text { NIS }\end{array}$ \\
\hline
\end{tabular}

Department :

Control Area:

Building: 3034

Room: Area:

HÄ Rating: Page:
Installation: ORNL

WA Code:

Cont Type Cd:
LOCTITE REMOVABLE THREADLOCKER 242

MASTER BUILDERS CONCRESIVE 1420 PARTS A \& B (REFER MOBIL DTE OIL EXTRA HEAVY

MOBIL DTE OIL HEAVY

NORTON RESINOID BONDED GRINDING WHEELS

NORTON RESINOID BONDED

OATEY HEAVY DUTY CLEAR PVC SOLVENT CEMENT

PRIMER/CLEANER

P-10 NUCLEAR COUNTER MIXTURE

PPG INDUSTRIES QUICK DRY ENAMEL - REGAL BLUE

PPG PITT-TECH HIGH GLOSS

PPG PITT-TECH SATIN 90-474

PPG QUICK DRY ENAMEL

PPG SPEEDHIDE LATEX FLAT PAINTS, $6-6-$

PPG SPEEDHIDE LO-SHEEN ENAMELS, $6-C$

REMIER ETP GOLD

PREMERER

PREMIER INDUSTRTAI PATCH

PREMIER INDUSTRIAL PATCH'N BOND FOR CONCRETE

RECTORSEAL (R) NO. $5(R)$

RID DARK THREAD CUTTING OII

RUBY'S STAINLESS STEEL SOLDERING FLUX

RUST VETO SPRAY

SIKAGARD 62, YELLLOW, GREEN, GRAY, RED, TAN (A2939, SILVER GOOP SIRCHIE FINGERPRINT LABORATORIES CLUE SPRAY - 7300 SODIUM HYPOCHLOR ITE SOLUTION
STAINLESS STEEL ALLOYS (REFER TO RECIDS A9465, A94
STEEL WOOL PADS

SYNKO INTERIOR AND EXTERIOR SPACKLING PASTE

THORO WATERPLUG (R)

USG JOINT TREATMENT PRODUCTS - READY MIXED COMPOUN MATERBURY TIME MIST AEROGEL DEODORANT 4 OZ - AIL WD-40 AEROSOL

WD-40 BULK LIQUID

WINFIELD BROOKS ALUMTAP

Building 3034 Totals:
SIRCHIE 719UV FLUORESCENT INVISIBLE DETECTION POWD

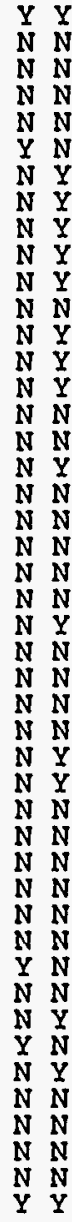

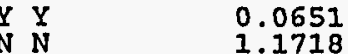

33.3812

8.3452
.0376

6.7500

6.6759

4.9632
2.0862

0.7500

100.2707

26.0373

60.5868

1539.7050

80.3646

16.6904

28.7910

41.7264

73.0212

6.2568

4.1727

2.0862

0.1304

12.8619

7.2604

0.3911

1.0001

233.6677

0.1954

0.7500

50.0717

55.3148

15.0000

$33 \cdot 3808$

41.7264

41.7264

0.5001

3.5202
4.1726

27.5387

4874.8985
0.0295

0.5310
15.1416

3.7853

11.3569

3.0617

3.2512

0.9462

0.3401
45.4823

45.4823
2.5669

11.8104

27.4818

698.4030

36.4527
7.5706

13.0593

18.9268

33.1221
2.0699

2.8368

1.8927

0.9462

0.0592

0.0888

5.8338

0.1774

0.4536

23.9236

105.9905

0.0886

0.1132

0.3400

22.7123

25.0906

6.8040

15.1412

15.1412

18.9269

1.596

1.5967

12.4907

12.4907
0.5914

$======$
211.2233

* indicates MSDS is not available
* indicates MSDS updated within last three months 
$12-1$

12. BUILDING 3038 (AHF, E, M)-ISOTOPE DEVELOPMENT LABORATORY 

ORNL FACILITY RmSE INFORMATION FORM

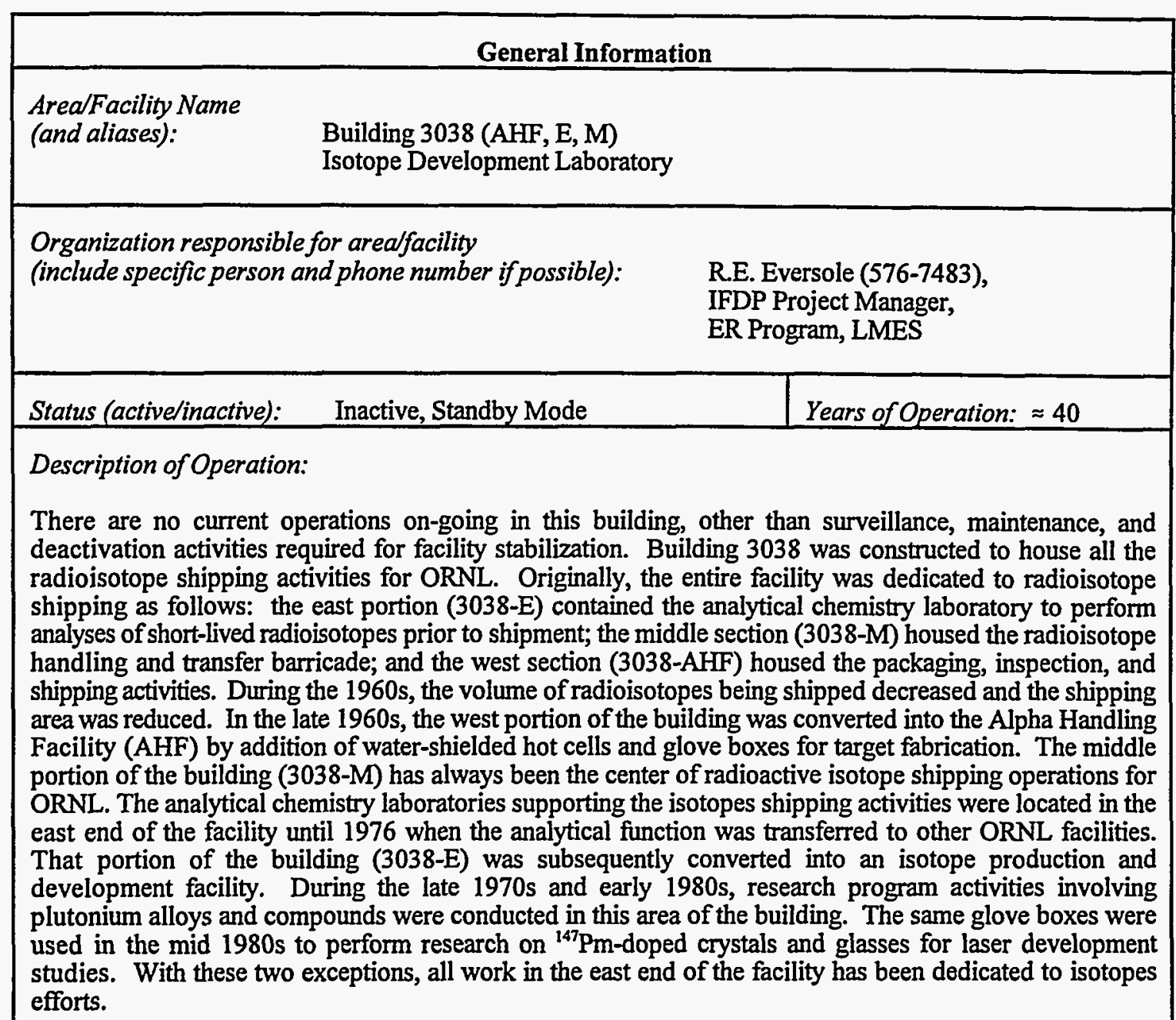

Physical description of arealfacility:

- Building 3038 was originally constructed in the late 1940 s.

- The facility is a single-story, metal frame building with brick siding consisting of approximately 7,250 sq. $\mathrm{ft}$. of floor space.

- Building 3038 is located in an industrial area of ORNL (Isotopes Circle).

- Building utilities include electric, steam, and plant air.

- The immediate area surrounding consists of a grassy area to the south and combination of pavement and grass skirting to the north, east, and west.

- Building 3038 consists of a number of hot cells, glove boxes, process hoods, and related equipment and process areas for handling and packaging radioactive materials. Work involving radioactive materials was conducted primarily in the hot cells, glove boxes, process hoods, and Radioactive Materials Shipping and Packaging area located in 3038-M.

- The building and hot cells are kept under negative pressure for containment purposes. Building ventilation is local and exhausts through high efficiency particulate air (HEPA) filters on the roof. Cell ventilation exhausts through HEPA filters to the cell ventilation system and stack 3039 . The manipulator cells and the glove boxes in the AHF and AHF Annex exhaust through HEPA filters to the isotopes area process off-gas system. 


\section{Physical description of arealfacility: (Continued)}

- Building sinks and floor drains discharge to process waste system. Hot cell drains discharged to the low-level liquid waste (LLLW) system (Tank WC-10). In addition, hood and sink operations in 3038-E also discharged to the LLLW system.

- Exterior of the building appears to be sound with no visual evidence of significant damage or deterioration.

- Access to some of the interior portions of the building was restricted during the facility inspection. The interior areas of the building that were accessible were observed to be in fair to good condition without any significant areas of damage or deterioration. Asbestos containing material (ACM) and items containing poly chlorinated bi-phenols are labeled as appropriate.

- A building space diagram is attached to this form showing the location of the various process areas and equipment.

\section{Release Information}

Description of release, or threatened release, and source:

Low levels of residual fixed and transferable radiologic surface contamination exist in areas of the facility as a result of historical operations. The contamination exists primarily in the hot cells, barricade area, a glove boxes, hoods and related process equipment (vessels, piping, ventilation ducts, etc.). This contamination has accumulated from activities involving a variety of materials throughout the operating history of the facility and, therefore, cannot be attributed to a single release episode. The existing levels of RAD surface contamination in the facility are low and the presence of this contamination is not considered a significant hazard in its current state according to the Building 3038 Hazard Screening Report.

The Hazard Screening Report does, however, indicate that a major potential hazard exists in the form of radiologic source material inventory remaining in the facility. This presents a potential for release of radiologic material from storage containers that might rupture during a natural phenomenon of other facility upset.

Hazardous materials (HAZMATs) (e.g., acids, hydraulic fluids, and other chemicals) were reportedly used in small quantities (i.e., less than 5 gallons or 100 pounds) during facility operations and currently for surveillance and maintenance (S\&M) activities. According to available spill/release records and facility personnel interviews, no significant HAZMAT spills (i.e., spills having the potential to adversely affect human health and/or the environment) have been reported for this building. No current conditions were identified which present a potential for a significant HAZMAT release.

Hazardous substances present:

Hazardous substances remaining in Building 3038 consist mainly of residual RAD surface contamination $(\alpha, \beta, \gamma)$, radioactive source materials, PCBs, and a small quantity of miscellaneous HAZMATs. Areas of fixed and transferable RAD contamination are associated primarily with the hot cells, barricade areas, glove boxes, hoods and related process equipment. Radioactive source materials are containerized in Department of Transportation (DOT) approved shipping containers and stored in the east and west ends of the facility. PCBs are reportedly present in the form fork lift hydraulic fluid within the building. Hazardous materials present in the building are listed on the attached HAZMAT inventory sheet. 
Estimate (if possible) of quantities of hazardous substances that have been released and that could be released:

The following represents the known quantities of substances currently existing in the facility. Radiologic surface contamination has accumulated from a legacy of many different programs and processes and cannot be attributed to a single release episode. It is only possible to quantify release amounts from contamination which currently exists in the facility and/or has been historically documented from past activities.

Residual Surface Contamination:

$\approx 10 \mathrm{mCi} \beta / \gamma$ as ${ }^{90} \mathrm{Sr}$

$<75 \mu \mathrm{Ci} \alpha$ as ${ }^{238} \mathrm{Pu}$

$<2 \mu \mathrm{Ci} \alpha$ as ${ }^{239} \mathrm{Pu}$

Radiologic Material Inventory:

$\approx 3,800 \mathrm{Ci} \alpha$ (the bulk as ${ }^{238} \mathrm{Pu}$ )

$\approx 10 \mathrm{Ci} \beta / \gamma$ (as ${ }^{90} \mathrm{Sr}$ equivalent)

Other Hazardous Substances:

PCB quantity not known (assumed to be less than 1 gallon).

$\approx 11$ pounds total miscellaneous HAZMATs (see attached HAZMAT inventory sheet).

(Radioactive material quantity estimates obtained from Building 3038 Hazard Screening Report; PCB quantity was not available in ORNL PCB Containing Equipment Inventory Database; HAZMAT quantity obtained from ORNL Hazardous Material Information System Database.)

\section{Other pollutants or contaminants:}

Asbestos containing material, primarily in the form of thermal system insulation, has been confirmed present in this building. ACM observed is in fair to good condition and poses no immediate health threat. Based on the age of the facility, interior and exterior painted surfaces are assumed to be lead-containing. Verification samples are taken by ORNL Lead Management Program personnel on an "as-needed" basis to confirm the presence of lead in the paint (i.e., when work activities will disturb the paint, or paint is found to be deteriorating and poses a health or environmental threat). Interior painted surfaces observed are in fair to good condition and pose no immediate health threat. The exterior of this building is brick and is not painted; therefore, no suspect areas of exterior lead-containing paint are associated with this building.

\section{Groundwater}

Are there any suspected impacts to groundwater? If yes, please describe. Include any impacts to drinking water sources.

Building 3038 is located in Waste Area Grouping (WAG) 1 at ORNL. Although no specific adverse spills or releases of hazardous substances threatening to groundwater were identified during this RmSE, it is suspected, based on available environmental studies conducted in WAG 1, that process and LLLW drains and associated piping may have leaked over the life of the facility. 
Are there any suspected impacts to groundwater? If yes, please describe. Include any impacts to drinking water sources. (Continued)

Buried process and LLLW piping and some drains have been found to be deteriorated and leaking in other facilities and areas of WAG 1 . Studies have determined that groundwater in WAG 1 has been both radiologically and chemically contaminated. Numerous man-made radionuclides have been detected in WAG 1 groundwater samples including many of those processed in Building 3038. It is likely that liquid waste from activities involving radioisotopes in Building 3038 have historically contributed to WAG 1 groundwater contamination. However, the radionuclides detected in the groundwater were common to the processes and activities in many other buildings in the area which makes it difficult to determine exactly which building is, or was, the source of contamination.

Because of the reported small quantities of chemicals historically and currently used in this facility, it is unlikely that such usage has significantly contributed to WAG 1 groundwater contamination. As part of the facility shutdown process, inactive process and LLLW drains within the building have reportedly been plugged to prevent further release. However, no documentation was available at the time of this report to verify which drains have actually been plugged and which have not. Information on drain locations and discharge points is available from the ORNL Engineering Support Office.

Other than the potential for historical impact to groundwater in WAG 1 via leaking process and LLLW lines external to the building, no existing immediate threat to groundwater was identified given the current status of the facility.

\section{Surface Water}

Are there any suspected impacts to surface water? If yes, please describe. Also describe the most likely surface water migration route(s), if applicable. Include any impacts to drinking water sources.

WAG 1 is essentially bound by Fifth Creek to the east, White Oak Creek (WOC) to the south, and First Creek to the west. First and Fifth creeks flow south into (WOC) which flows to the west and exits WAG 1 at the southwest corner. Storm water (from surface runoff and storm water drainage system) and treated water from the process waste system discharges into WOC. Since the exterior surfaces of this building are not painted, no potential for direct impact to surface water from Building 3038 was identified in its current state.

Surface water may, however, have historically been indirectly impacted by leaking process and LLLW lines external to the building. Some of these lines are known to have shared a common trench with storm water drainage piping. Contamination from leaking waste lines could potentially enter deteriorated storm water piping and migrate to WOC. The three creeks bordering WAG 1 are groundwater discharge points. Therefore, groundwater contaminated by leaking waste lines could also potentially impact surface water in the area.

No existing immediate threats to surface water were identified to be associated with Building 3038 during this RmSE.

\section{Air}

Are there any suspected impacts due to air emissions? If yes, please describe.

The Hazard Screening Report prepared for Building 3038 indicates a slight potential for radiation exposure to personnel working inside and within the immediate vicinity of the facility exists due to potential airborne migration of radioactive particulates and physical contact with contaminated surfaces. 
Are there any suspected impacts due to air emissions? If yes, please describe. (Continued)

Also indicated is the greater potential of exposure due to catastrophic failure of containers of radioactive source material. Release of this material could pose a major airborne threat to personnel within and in the immediate vicinity of Building 3038. Areas of RAD contamination are identified, marked, and controlled as appropriate throughout the facility to protect against inadvertent exposure to personnel. Air in the building is controlled by a combination of a local ventilation system which controls building air, the cell ventilation system which controls hot cell exhaust, and the process off-gas system which controls exhaust from manipulator cells and glove boxes in the AHF and AHF Annex. Apart from catastrophic failure of the hot cells, glove boxes, structure, ventilation systems, or other contaminated equipment, it is unlikely that radioactive air emissions from Building 3038 would impact personnel or the environment in its current state.

There is also a potential for impact to indoor air quality due to the presence of ACM and assumed lead-based paint (LBP) should these materials be disturbed. The ACM and assumed LBP remaining in the building are not considered to be immediate threats to indoor quality in their current state.

\section{Soil}

Are there any suspected impacts to soil? If yes, please describe.

As stated for groundwater, there is a potential for historical impact to soils in the area of Building 3038 due to leaking process and LLLW drain piping. Previous environmental studies have identified a soil contamination plume in the Isotopes Circle area and soil samples collected from the plume have detected radioisotopes common to the processes performed in this building. An area of contaminated soil exists around the southeast comer of Building 3038. Reportedly this area is suspected to be the result of an abandoned waste tank and piping in the area that has leaked in the past. The area is well marked and covered with a protective barrier and river rock. Information specific to this area of contamination was not identified during this RmSE. As a result, it is likely that operations in this facility have historically contributed to the Isotopes Circle soil contamination plume. This area of contamination is not considered an imminent hazard given the current status of the adjacent facility (Building 3038) and the protective measures being taken to prevent contamination migration and personnel exposure.

It is unlikely that the small quantities of chemicals used in Building 3038 will, or have, significantly impact(ed) soil in the surrounding area.

\section{Release Beyond Facility or Reservation Boundaries}

Has or will the release migrate beyond the boundaries of the facility or reservation? If yes, please describe (including possible human or environmental receptors).

The following are considered potential scenarios where radiologic contamination could migrate beyond the facility or reservation boundaries:

- A person becomes inadvertently contaminated and leaves the facility/reservation undetected.

- Catastrophic failure of hot cells and/or contaminated equipment.

Though these potentials exist, they are considered slight and unlikely due to the current status of the facility and the engineering/administrative controls that are in place to protect again such an event. 


\section{Worker Safety}

\section{Could the release pose a threat to workers? If yes, please describe.}

Radiologically contaminated areas are isolated and well marked. Good radiation practices and standard operating procedures are enforced for worker safety. Personnel exiting the facility are required to "frisk" themselves to detect the presence of RAD contamination. Monitors and alarms are in place to detect any radioactive release within the building. PCB containing equipment and ACM are appropriately labeled. However, even with these safeguards in place, a potential threat to workers exists if safety measures are overlooked. This potential is not considered significant given the current status and level of activity of the building.

\section{Environmental Receptors}

Does the release pose a potential threat to environmental receptors? If yes, please describe. Include natural resources impacts.

No existing conditions posing an immediate significant threat to environmental receptors, including natural resources, were identified to be currently existing or associated with Building 3038 .

\section{Mitigation}

What action(s) might be taken to abatelprevent release or impacts from release?

- Continued utilization and enforcement of engineering and administrative controls that are currently in place to protect workers and monitor conditions and activities in the building.

- Continue S\&M activities per Procedure IP-900.

What actions are currently being taken to abate/prevent release or impacts from release?

Engineering and administrative controls are in place to control access to contaminated areas and to monitor conditions and activities within the facility for worker and environmental protection. Warning signs and labels are posted throughout the facility indicating $\mathrm{RAD}, \mathrm{ACM}$, and $\mathrm{PCB}$ hazard areas. Standard operating procedures are in place for building access and surveillance and maintenance activities to protect against inadvertent contact and disturbance of contaminated areas and materials. Radiologically contaminated areas are monitored periodically by ORNL health physics personnel. Personnel are "frisked" upon exit of the facility to detect the presence of radiologic contamination. The building is currently in surveillance and maintenance status awaiting entry into the Decontamination and Decommissioning (D\&D) Program. Inactive waste drains are reportedly plugged in contaminated areas to prevent inadvertent discharge of contamination beyond the facility. A groundwater monitoring program is in place to monitor contamination levels and migration in groundwater underlying WAG 1 . The building is inspected for structural changes after each natural incident (earthquake, tornado, or other severe storm), fire and/or man induced activity which could cause cracking, failure, or deterioration of the facility and/or equipment that may allow contamination to be released. No such conditions have been reported for Building 3038 .

Current actions being taken to prevent further release and ensure worker safety in Building 3038 are considered adequate until D\&D activities begin.

\section{Other Environmental Authorities}

Is the release or threatened release potentially subject to other environmental statutory actions? If yes, please explain.

If paint is found to be lead-containing and samples fail the Toxicity Characteristic Leaching Procedure (TCLP) analysis, the building could qualify as a hazardous waste generator point under the Resource Conservation and Recovery Act (RCRA). 
Maintenance Actions

Are maintenance actions necessary to eliminate potential threats to human health and the environment? If so, explain.

No existing potential hazards requiring maintenance actions were identified to be associated with Building 3038.

\section{Removal Actions}

Are Removal Actions necessary to eliminate immediate threats to human health and the environment? If so, explain.

No imminent hazards requiring removal actions per 40 CFR 300.415 were identified to be currently associated with Building 3038 .

\section{Remedial Site Evaluation}

Is a Remedial Site Evaluation needed?

Areas of radiologic contamination associated with Building 3038 have been identified and marked as appropriate. However, it is suspected that process and LLLW drains and associated piping may have leaked beneath the slab of the building as a result of past practices. As a result, it is recommended that some type of remedial investigation be performed to assess the condition of the soil in this area before conducting any S\&M or D\&D activities which involve disturbing the slab.

$\mathrm{ACM}$ and PCB-containing equipment have also been identified, marked and documented. No further remedial investigation involving these hazards is considered necessary given the current status and future plans of this facility.

Based on the age of the facility, painted surfaces are assumed to contain lead. Samples of the paint should be taken and analyzed to verify the presence of lead prior to conducting any S\&M or D\&D activities which may disturb these assumed areas.

\section{No Further Investigation}

\section{Is a finding of No Further Investigation appropriate? Please explain.}

A finding of No Further Investigation implies that a facility or area is free from hazardous substances or contaminants that may threaten human health and the environment. Since Building 3038 contains substances and materials which may become threatening if not properly controlled, handled and managed during the S\&M cycle, a finding of No Further Investigation is inappropriate in this case. 
The following documents and databases were referenced for historical and hazard information related to Building 3038:

- Phase I Safety Documentation, The Isotope Development Laboratory, Building 3038, Hazard Screening, Document No. HS/3038/F/RT-15 (Rev. 1).

- Work Plan for the Isotopes Facilities Deactivation Project at Oak Ridge National Laboratory, Document No. ORNL/ER-249/R2.

- Building 3038 Occurrence Reports, 1989 to present.

- Site Characterization Summary Report for Waste Area Grouping 1 at Oak Ridge National Laboratory, Oak Ridge, Tennessee, Volumes 1 and 2, Document Nos. DOE/OR-1043/V1\&D1 and DOE/OR-1043/V2\&D1.

- ORNL Hazardous Material Information System Database.

- $\quad$ ORNL Drain System Survey Report for Building 3038.

The following personnel and offices were contacted and provided historical and current use/condition information for Building 3038:

- Mr. Karl Haff, Radiochemical Processing Department Head, ORNL Radiochemical Technology Section.

- Ms. Swati Wilson, Manager, ORNL Lead Management Program.

- Mr. Nathan Dunn, Hazardous Material Information System Office.

- Mr. Jade Thomas, ORNL Environmental Compliance Office.

- Mr. Joe Armento, ORNL Chemical Technology Division, Isotopes Facilities Shutdown Program.

The RmSE of this facility was conducted for LMES under contract by:

Advanced Sciences, Inc.

800 Oak Ridge Turnpike, Suite C-102

Oak Ridge, TN

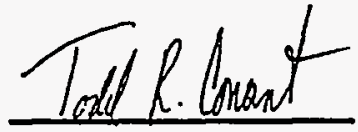

Evaluator's Signature

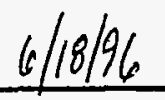

Date 

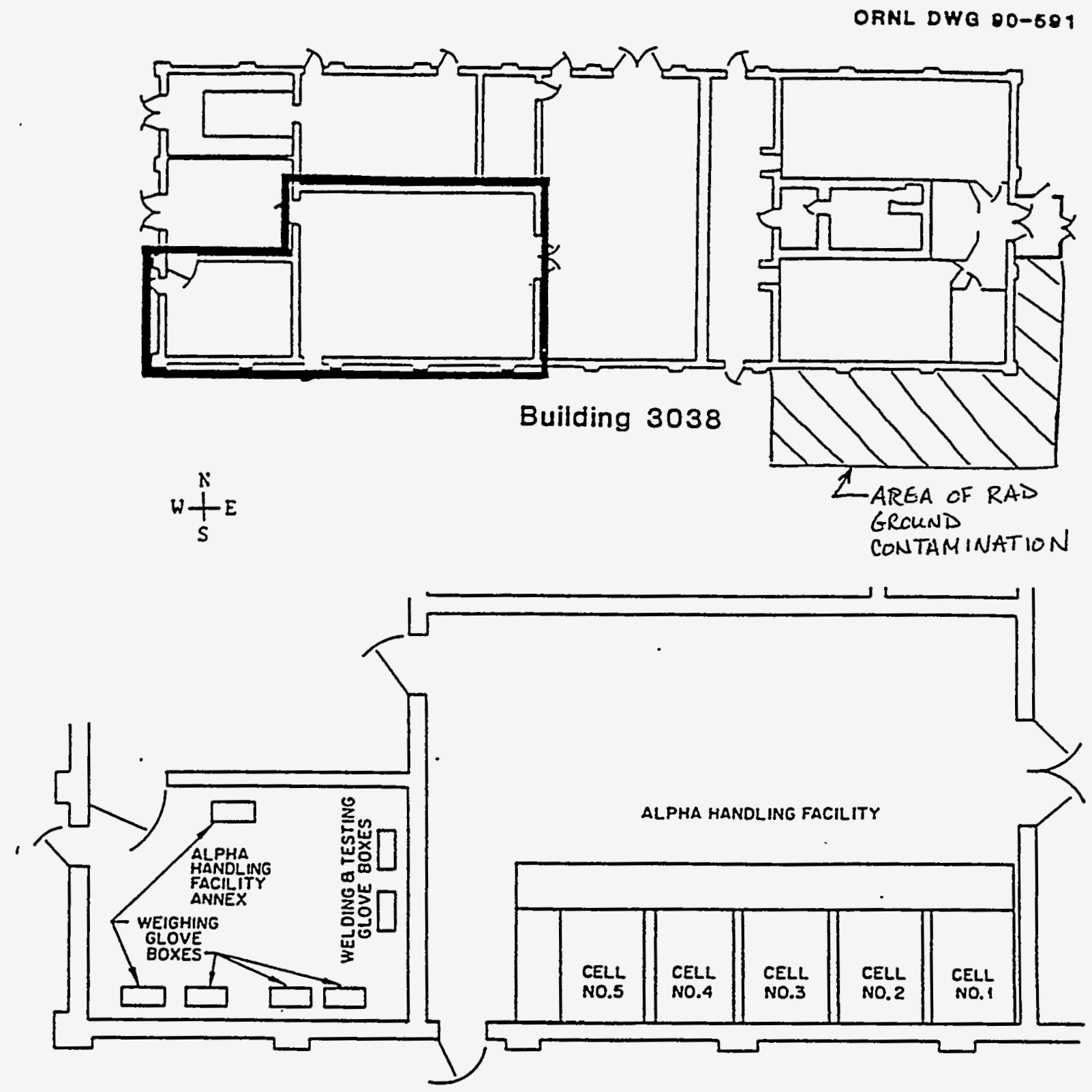

\section{Building 3038-AHF}

Fig. 13. Diagram of Building 3038-AHF. 


\section{Building 3038}

ORNL DWG 80-602
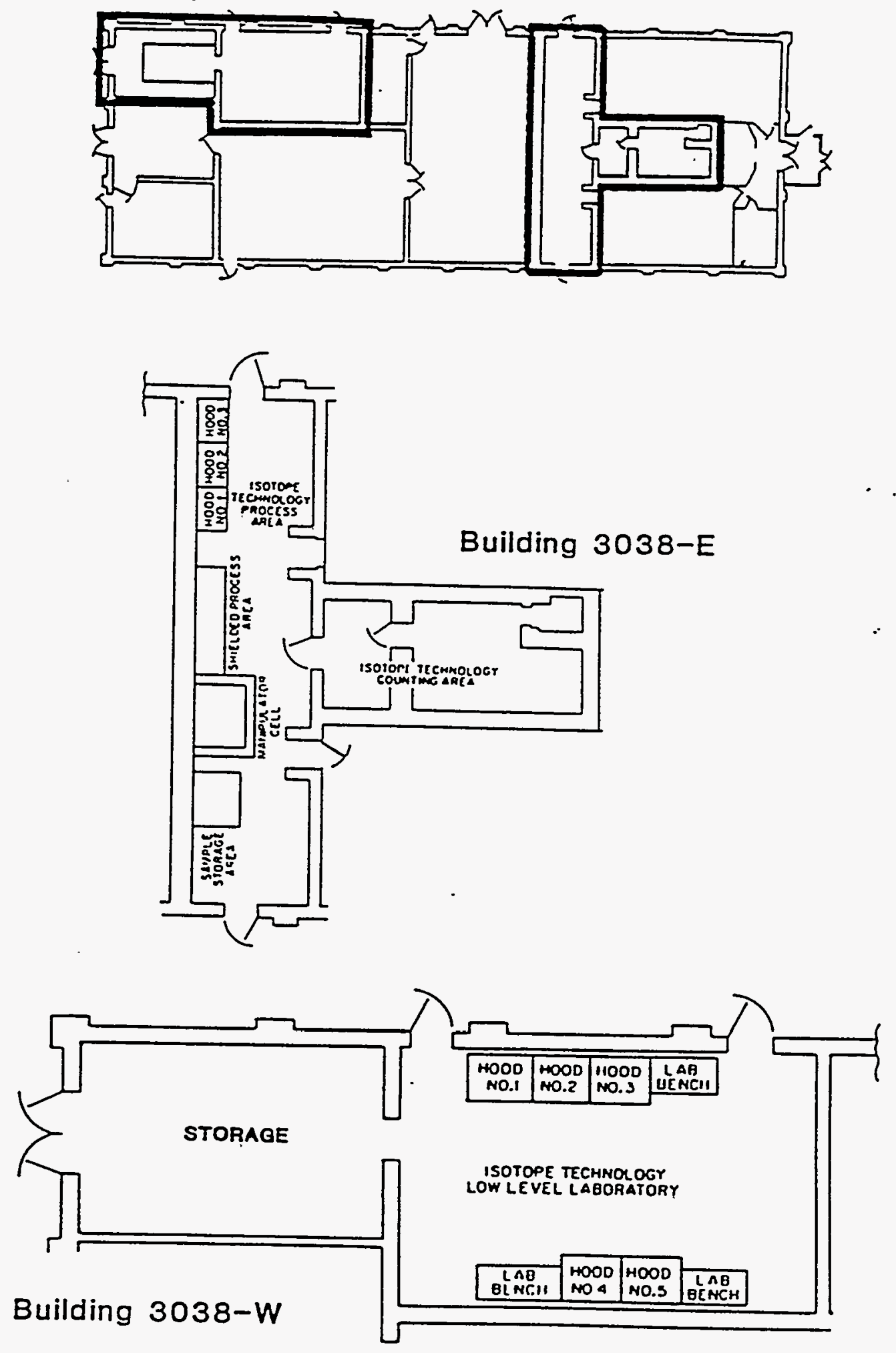

Fig. 14. Diagram of Building 3038-W. 


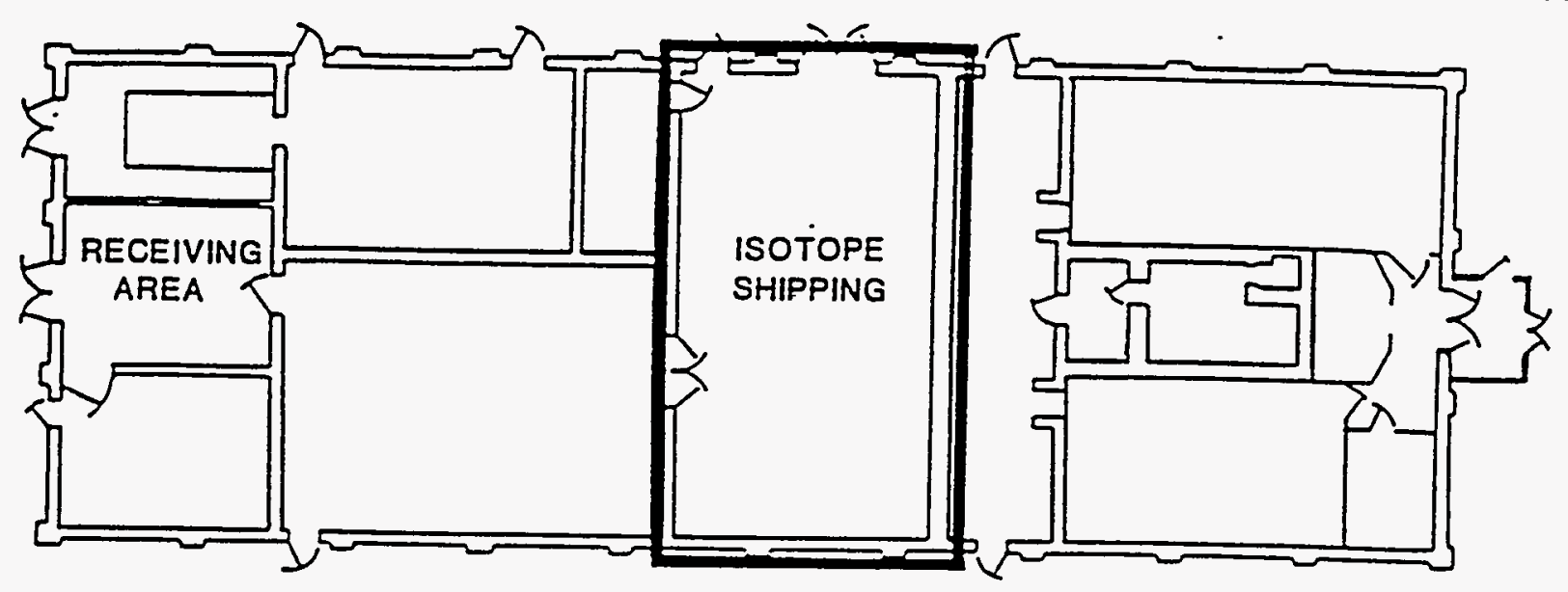

$\omega \frac{\hat{N}}{S} E$

Building 3038

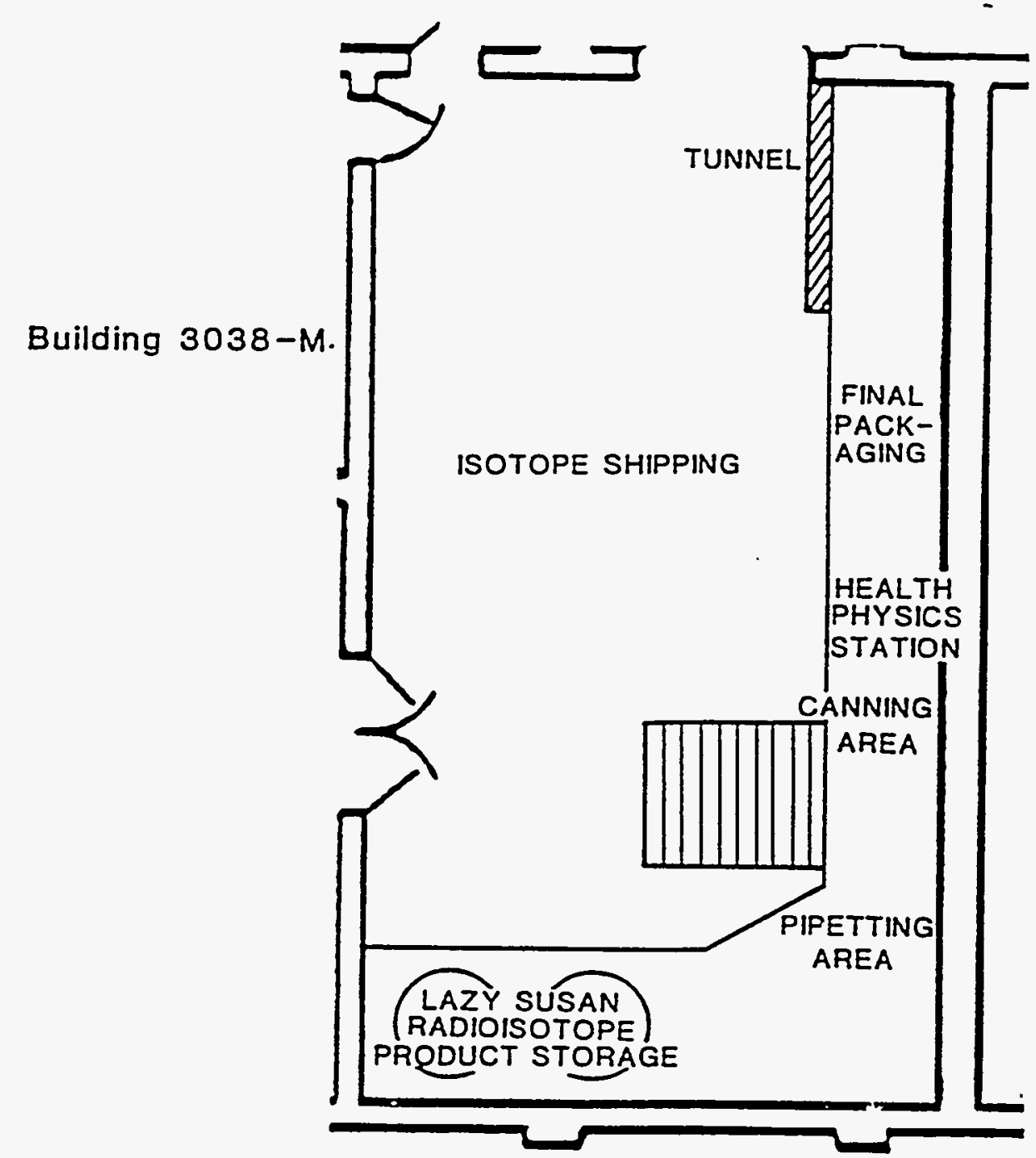

Fig. 15. Diagram of Building 3038-M. 
ORNL DWG 80-504

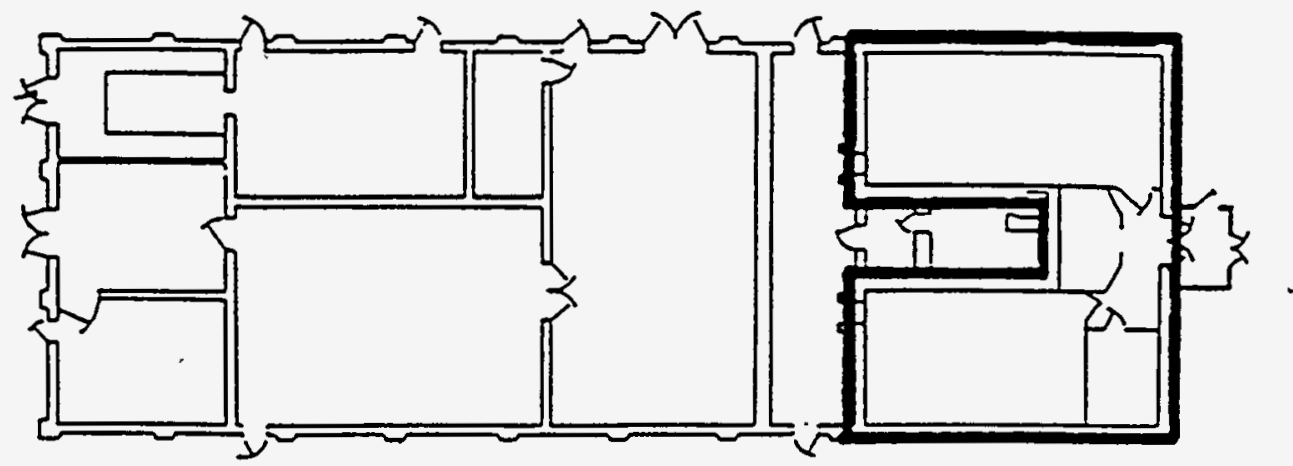

Building 3038

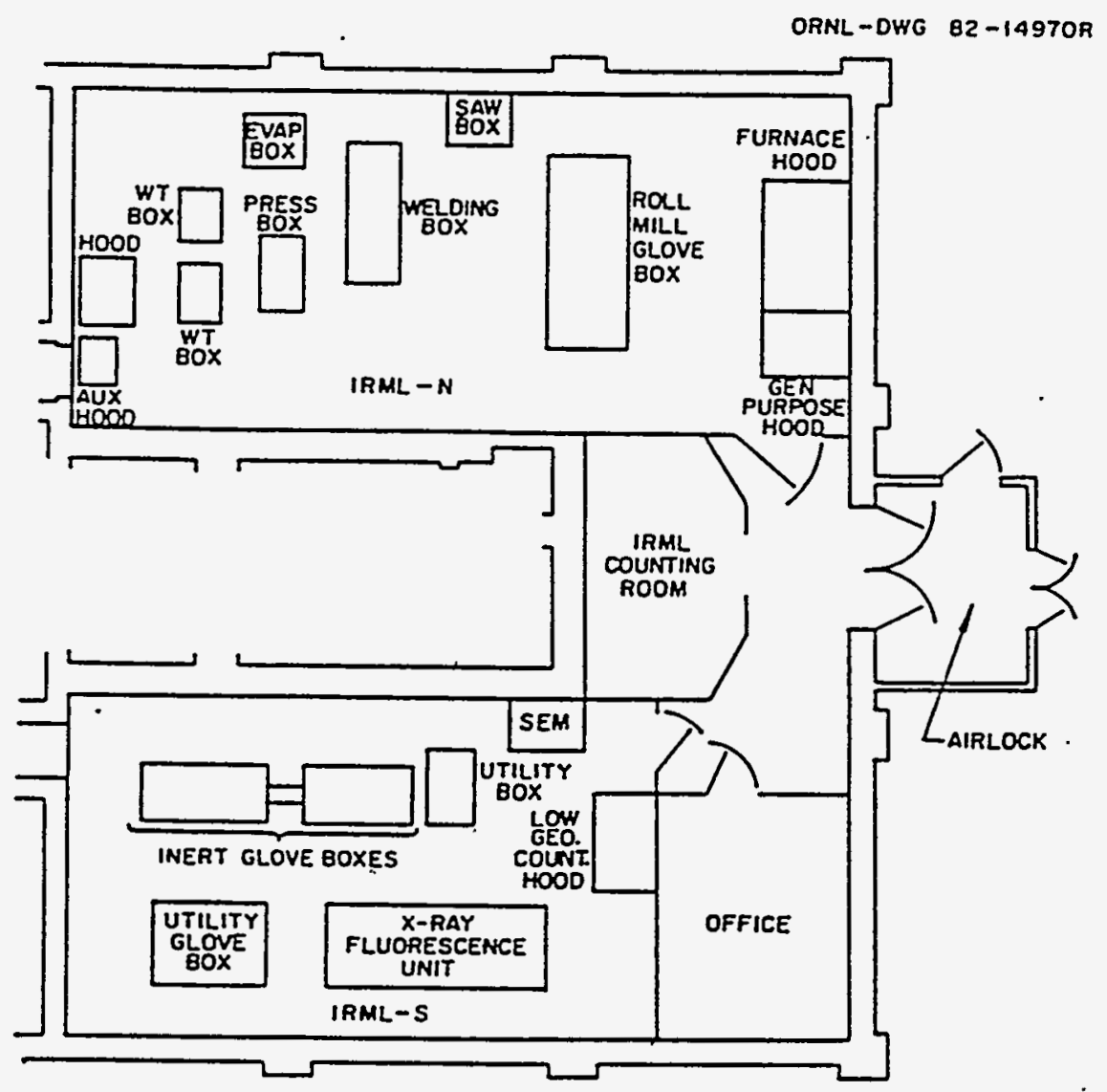

Building 3038-E

Fig. 16. Diagram of Building 3038-E. 
กithsR $003 \mathrm{C}$

$13: 42: 49$

Plant: 3 Division:

Item ID

Date Expiration:

Building: 3038

\begin{tabular}{lll} 
RECID & $\star$ & CASNO \\
\hdashline 87241 & - & NISS \\
81193 & NISS \\
89515 & NISS \\
94226 & NISS \\
97063 & NISS \\
00318 & N00067-56-1 \\
89448 & NISS \\
92251 & NISS \\
91032 & NISS
\end{tabular}

Material Name

VACUUM GREASE

DOW CORNING (R) HIGH VACUUM GREASE

FORMULA 409 ALL PURPOSE CLEANER

HOUSEHOLD (HANDY) OIL

J. PENNER CRT CLEAN SOLUTION

METHANOL

PPG QUICK DRY SPRAY ENAMELS, 55-B

SANFORD ROLL-ON STAMP PAD INKER

SELIG MASTER MECHANIC LIQUID

Building 3038 Totals :
$03-28-1996$

UNCLASSIFIED

Page: ${ }^{1}$
Installation: ORNL
WA Code:
Page: 1
Installation: ORN
WA Code:

Area:

Cont Type Cd:

\begin{tabular}{|c|c|c|c|}
\hline $\begin{array}{l}\text { MMES } \\
\mathrm{C} R\end{array}$ & 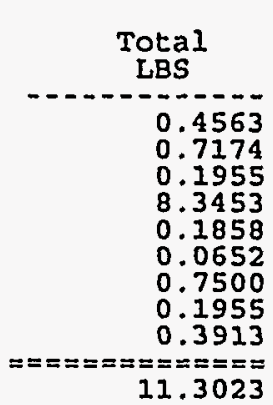 & 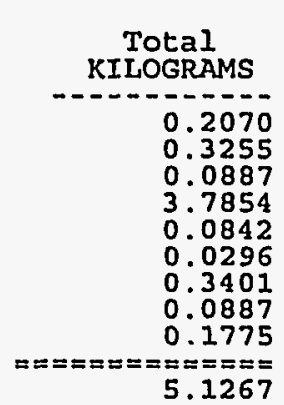 & 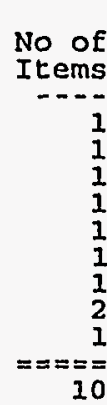 \\
\hline
\end{tabular}

* indicates MSDS is not available 

13. BUILDING 3047-RADIOISOTOPE DEVELOPMENT LABORATORY 



\section{ORNL FACILITY RmSE INFORMATION FORM}

\begin{tabular}{|c|c|}
\hline \multicolumn{2}{|c|}{ General Information } \\
\hline $\begin{array}{l}\text { Building } 3047 \\
\text { The Radioisotope Developme }\end{array}$ & $\begin{array}{l}\text { Building } 3047 \\
\text { The Radioisotope Development Laboratory (RDL) }\end{array}$ \\
\hline \multicolumn{2}{|c|}{$\begin{array}{ll}\text { Organization responsible for arealfacility } & \\
\text { (include specific person and phone number if possible): } & \text { R.E. Eversole (576-7483), } \\
& \text { IFDP Project Manager, } \\
& \text { ER Program, LMES }\end{array}$} \\
\hline Status (active/inactive): & Years of Operation: $\approx 30$ \\
\hline \multicolumn{2}{|c|}{$\begin{array}{l}\text { All isotopes activities within Building } 3047 \text { are shutdown with the exception of waste removal and } \\
\text { transloading of radioactive material in the beta/gamma hot cells. There are currently a large number of } \\
\text { different work items performed within this facility. Actual operations can involve temporary storage and } \\
\text { movement of discrete items of inventory; trans-loading/shipment of items (transfer of items from on carrier } \\
\text { or cask to another); receipt, packaging, repackaging, transfer, and shipment of radioactive material; and the } \\
\text { unloading, opening, handling, repackaging, and shipment of liquid and solid radioactive materials including } \\
\text { waste. The Health Sciences Research Division (HSRD) utilizes parts of this facility for processing medical } \\
\text { radioisotopes and radiopharmaceutical research. The hot cells are used for opening High-Flux Isotopes } \\
\text { Reactor target capsules and transloading highly radioactive materials. Laboratories } 209 \text { and } 210 \text { are } \\
\text { currently not in use but are expected to be used by theIsotope Production and Distribution Program. } \\
\text { Laboratory } 208 \text { is used by HSRD staff as an analytical and research facility. Laboratory } 207 \text { may also be } \\
\text { used by the Isotope Production and Distribution Program. }\end{array}$} \\
\hline \multicolumn{2}{|c|}{$\begin{array}{l}\text { Historically, this facility has been used for research, development, and production of radioisotopes. The } \\
\text { Medical Isotopes Section (now the Nuclear Medicine Group) of the HSRD has utilized several laboratories } \\
\text { for nuclear medicine research. No specific descriptions can be given for past processing performed in RDL } \\
\text { because of frequent changes not only in the processes themselves but also in the materials, operating } \\
\text { procedures and parameters, and program requirements. Special safety summaries and approved procedures } \\
\text { were required for each new experiment and operation. Before an operation could begin, all pertinent } \\
\text { paperwork had to be reviewed and approved. If any potential hazard were identified, additional reviews and } \\
\text { approvals were needed. Reviews identified and analyzed potential hazards that might be different in degree } \\
\text { or type from those previously approved. }\end{array}$} \\
\hline \multicolumn{2}{|l|}{ Physical description of arealfacility: } \\
\hline
\end{tabular}


Physical description of arealfacility: (Continued)

- Building ventilation is divided into three zones; west, middle, and east. The west and middle zones operate under slight negative pressure, and the east zone is not contained. Exhaust ventilation of Hot Cells A, B, C, and D is provided by the cell ventilation system, exhaust ventilation of the Alpha Hot Cell is provided by the process off-gas system.

- The exterior of building is generally clean and in good condition with no visible areas of significant deterioration or damage.

- The interior portions of the building fair to good condition with no visible areas of significant deterioration or damage.

- Building 3047 is located in Isotopes Circle, an industrial area of ORNL. The immediate area surrounding the facility is paved.

- RDL houses four high-level beta/gamma hot cells (A-D), one alpha hot cell, seven laboratories for handling low-level materials, a decontamination room, a Health Physics (HP) area, offices, and service areas. Utilities include electrical power, steam, and plant air.

- Cell floor drains, some hood drains, and drains in the decontamination facility discharge to the LLLW system (Tank WC-10). The remaining floor, sink, and hood drains discharge to the process waste system.

- Work with radioactive materials was/is conducted primarily in the hot cells and laboratories within the building. Resulting primary waste streams included exhaust air and liquid process waste.

- A building space diagram is attached to this form showing the location of the various process areas and equipment.

Release Information

Description of release, or threatened release, and source:

Low levels of residual fixed and transferable radiologic surface contamination exist in areas of the facility as a result of historical operations. The contamination exists primarily in the hot cells and process equipment (vessels, hoods, piping, ventilation ducts, etc.). This contamination has accumulated from activities involving a variety of materials throughout the operating history of the facility and, therefore, cannot be attributed to a single release episode. The existing levels of RAD contamination in the facility are low and the presence of this contamination is not considered a significant hazard in its current state. The potential for release of additional radiologic contamination exists due to inventory of radioactive materials currently stored in the facility in limited quantities. The existing levels of residual RAD surface contamination in the facility are low, especially in comparison with the remaining radiologic material inventory, and the presence of this contamination is not considered a significant hazard in its current state.

Hazardous materials (HAZMATs) (e.g., acids, hydraulic fluids, and other chemicals) were reportedly used in small quantities (i.e., less than 5 gallons or 100 pounds) historically during facility operations and currently for surveillance and maintenance (S\&M) activities. A large number of HAZMATs are currently used and stored within Building 3047, the majority of the individual items consist of less than one pound of material. Two of these materials were identified in the Hazard Screening Report to be potential significant hazard sources. These chemicals are chloroform and benzene, which are listed as human carcinogens by the Occupational Safety and Health Administration and the American Conference of Government Industrial Hygienists. These chemicals are used only in laboratory hoods while the containers are open and no more than $20 \mathrm{~kg}$ of each chemical is present in the facility at one time. A release of these chemicals within the building would result in minor effects on any personnel in the immediate vicinity of the accident. According to available spill/release records and facility personnel interviews, no significant HAZMAT spills (i.e., spills having the potential to adversely affect human health and/or the environment) have been reported for this building. No current conditions were identified which present a potential for a significant HAZMAT release within the building.

There was a small diesel fuel spill identified around the pad of the emergency generator located adjacent to the northwest wall of the facility. This leak poses an immediate threat to surface water and is discussed in more detail in the Surface Water section of this report. 
Hazardous substances present:

Hazardous substances remaining in Building 3047 consist mainly of residual RAD surface contamination $(\alpha, \beta, \gamma)$, radioactive materials in storage, PCBs, and a number of small quantities of miscellaneous HAZMATs including chloroform and benzene. Areas of fixed and transferable RAD contamination are associated primarily with the hot cells and process equipment. PCBs are reportedly present in small electrical capacitors. Hazardous materials present in the building are listed on the attached HAZMAT inventory sheets.

Estimate (if possible) of quantities of hazardous substances that have been released and that could be released:

The following represents the known quantities of substances currently existing in the facility. Radiologic surface contamination has accumulated from a legacy of many different programs and processes and cannot be attributed to a single release episode. It is only possible to quantify release amounts from contamination which currently exists in the facility and/or has been historically documented from past activities.

Residual Radiologic Surface Contamination:

$<1 \mathrm{mCi} \beta / \gamma$ as ${ }^{90} \mathrm{Sr}$

$<5 \mathrm{mCi} \alpha$ as ${ }^{239} \mathrm{Pu}$

Radiologic Material Inventory:

$\approx 3,000 \mathrm{Ci} \alpha$ (the bulk as ${ }^{238} \mathrm{Pu}$ )

$\approx 500,000 \mathrm{Ci} \beta / \gamma$ (as ${ }^{90} \mathrm{Sr}$ equivalent)

Other Hazardous Substances:

$\approx 1$ gallon PCBs

$\approx 4,923$ pounds total miscellaneous HAZMATs (see attached HAZMAT inventory sheet).

(Quantity estimates obtained from Building 3047 Hazard Screening Report, ORNL PCB Large High- and Low-Voltage and Small Capacitors Inventory database, ORNL Hazardous Material Information System database.)

Other pollutants or contaminants:

Asbestos containing material (ACM), primarily in the form of thermal system insulation, has been confirmed present in this building. ACM observed is in good condition and poses no immediate health threat. Based on the age of the facility, interior and exterior painted surfaces are assumed to be lead-containing. Verification samples are taken by ORNL Lead Management Program personnel on an "as-needed" basis to confirm the presence of lead in the paint (i.e., when work activities will disturb the paint, or paint is found to be deteriorating and poses a health or environmental threat). Interior painted surfaces observed are in good condition and pose no immediate health threat. Paint on exterior surfaces was observed to be in good condition with no visible evidence of significant damage or deterioration. 


\section{Groundwater}

Are there any suspected impacts to groundwater? If yes, please describe. Include any impacts to drinking water sources.

Building 3047 is located in Waste Area Grouping 1 at ORNL. Although no specific adverse spills or releases of hazardous substances threatening the groundwater were identified during this RmSE, it is suspected, based on available environmental studies conducted in WAG 1, that process and LLLW drains and associated piping may have leaked over the life of the facility. Buried process and LLLW piping and some drains have been found to be deteriorated and leaking in other facilities and areas of WAG 1. Studies have determined that groundwater in WAG 1 has been both radiologically and chemically contaminated. Numerous man-made radionuclides have been detected in WAG I groundwater samples including many of those processed in Building 3047. It is likely that liquid waste from activities involving radioisotopes in Building 3047 have historically contributed to WAG 1 groundwater contamination. However, the radionuclides detected in the groundwater were common to the processes and activities in many other buildings in the area which makes it difficult to determine exactly which building is, or was, the source of contamination.

Because of the reported small quantities of chemicals historically and currently used in this facility, it is unlikely that such usage has, or will, significantly contribute(d) to WAG 1 groundwater contamination. As part of the facility shutdown process, inactive process and LLLW drains within the building have reportedly been plugged to prevent further release. However, no documentation was available at the time of this report to verify which drains have actually been plugged and which have not. Information on drain locations and discharge points is available from the ORNL Engineering Support Office.

Other than the potential for historical impact to groundwater in WAG 1 via leaking process and LLLW lines external to the building, no existing immediate threat to groundwater was identified given the current status of the facility.

\section{Surface Water}

Are there any suspected impacts to surface water? If yes, please describe. Also describe the most likely surface water migration route(s), if applicable. Include any impacts to drinking water sources.

WAG 1 is essentially bound by Fifth Creek to the east, White Oak Creek (WOC) to the south, and First Creek to the west. First and Fifth creeks flow south into (WOC) which flows to the west and exits WAG 1 at the southwest corner. Storm water (from surface runoff and storm water drainage system) and treated water from the process waste system discharges into WOC. An immediate, direct threat to surface water is associated with the emergency diesel generator located adjacent to the northwest wall of the building on the concrete apron. A portion of the concrete pad supporting the generator was found to be soaked with diesel fuel (an area of approximately four square feet). This area is susceptible to rainwater which can wash the fuel off the pad and channel it along the concrete apron into Fifth Creek to the east of the building. Though the area of fuel is small, continued leakage and subsequent rain events can compound the impact to Fifth Creek.

The only other potential for direct impact to surface water from Building 3047 in its current state would be from lead-containing paint chips which fall off the exterior painted surfaces and find their way into the storm water drainage system and eventually to WOC. Based on the age of this facility, it is assumed that painted surfaces contain lead. The exterior paint of Building 3047 is in good condition and there was no visible evidence of deterioration observed during the site inspection. Therefore, the potential for impact to surface water due to assumed exterior lead-based paint is considered slight.

Surface water may have also been indirectly impacted by leaking process and LLLW lines external to the building. Some of these lines are known to have shared a common trench with storm water drainage piping. Contamination from leaking waste lines could potentially enter deteriorated storm water piping and migrate to WOC. The three creeks bordering WAG 1 are groundwater discharge points. Therefore, groundwater contaminated by leaking waste lines could also potentially impact surface water in the area. 


\section{Air}

Are there any suspected impacts due to air emissions? If yes, please describe.

The Hazard Screening Report prepared for Building 3047 indicates that the potential for radiation exposure to personnel working inside and within the immediate vicinity of the facility as a result of potential airborne migration of radioactive particulates and physical contact with contaminated surfaces is considered insignificant. There is, however, a potential for significant radiation exposure to personnel as a result airborne migration of particulates from the remaining inventory of radioactive material should containment of this material be compromised. Areas of $\mathrm{RAD}$ contamination are identified, marked, and controlled as appropriate throughout the facility to protect against inadvertent exposure to personnel. Air in the building is controlled by the cell ventilation system (hot cells A-D), process off-gas system (alpha hot cell), and local ventilation systems (west, middle, and east building zones). Exhaust air from hot cells A-D, the alpha hot cell, the west building zone, and the middle building zone is filtered through high efficiency particulate air (HEPA) filtration units before discharge to local exhaust stacks or stack 3039. Apart from catastrophic failure of the hot cells, storage equipment, or ventilation systems, it is unlikely that radioactive air emissions from Building 3047 would impact personnel or the environment in its current state.

There is also a potential for impact to indoor air quality due to the presence of ACM, assumed lead-based paint (LBP), chloroform, and benzene should these materials be disturbed or release within the facility. The $A C M$ and assumed LBP remaining in the building are not considered to be immediate threats to indoor quality in their current state. Special handling procedures are implemented for usage of chloroform and benzene within the building to prevent release and personnel exposure.

\section{Soil}

Are there any suspected impacts to soil? If yes, please describe.

As stated for groundwater, there is also a potential for historical impact to soils in the area of Building 3047 due to leaking process and LLLW drain piping. Previous environmental studies have identified a soil contamination plume in the Isotopes Circle area and soil samples collected from the plume have detected radioisotopes common to the processes performed in Building 3047. Since, these radioisotopes were common to the processes in many of the other buildings in the area, it is difficult to determine whether waste from Building 3047 has actually contributed to the Isotopes area soil contamination plume based on the information reviewed during this RmSE.

It is unlikely, however, that the small quantities of chemicals used in Building 3047 have, or will, significantly impact(ed) soil in the surrounding area.

\section{Release Beyond Facility or Reservation Boundaries}

Has or will the release migrate beyond the boundaries of the facility or reservation? If yes, please describe (including possible human or environmental receptors).

The following are considered potential scenarios where radiologic contamination could migrate beyond the facility or reservation boundaries:

- Leaking diesel fuel around the base of the emergency generator is washed away with storm water and is carried away from the facility and potentially the reservation via Fifth and White Oak Creeks.

- A person becomes inadvertently contaminated and leaves the facility/reservation undetected.

- Catastrophic failure of hot cells and/or contaminated equipment.

There is also a potential for assumed lead-containing paint which peels off of the building to be carried away with surface runoff during a rain event. With the exception of the diesel fuel leak, these potential scenarios are considered slight and unlikely due to the current status of the facility and the engineering/administrative controls that are in place to protect again such an event. 


\begin{abstract}
Worker Safety
Could the release pose a threat to workers? If yes, please describe.

Radiologically contaminated areas are isolated and well marked. Good radiation practices and standard operating procedures are enforced for worker safety. Personnel exiting the facility are required to "frisk" themselves to detect the presence of RAD contamination. Monitors and alarms are in place to detect any radioactive release within the building. Asbestos containing material and PCB items are appropriately labeled. However, even with these safeguards in place, a potential threat to workers exists if safety measures are overlooked. This potential is not considered significant given the current status and level of activity of the building.
\end{abstract}

Environmental Receptors

Does the release pose a potential threat to environmental receptors? If yes, please describe. Include natural resources impacts.

No significant immediate threat to environmental receptors within the area surrounding Building 3047 was found to exist as a result of contamination and conditions currently present in the facility.

\begin{tabular}{|c} 
Mitigation \\
\hline What action(s) might be taken to abate/prevent release or impacts from release?
\end{tabular}

- Clean up area of diesel fuel on concrete pad around emergency generator. Identify and repair source of leak.

- Continued utilization and enforcement of engineering and administrative controls that are currently in place to protect workers and monitor conditions and activities in the building.

- Continue S\&M activities per Procedure IP-900.

What actions are currently being taken to abate/prevent release or impacts from release?

Engineering and administrative controls are in place to control access to contaminated areas and to monitor conditions and activities within the facility for worker and environmental protection. Warning signs and labels are posted throughout the facility indicating RAD, ACM, and PCB hazard areas. Standard operating procedures are in place for building access and surveillance and maintenance activities to protect against inadvertent contact and disturbance of contaminated areas and materials. Radiologically contaminated areas are monitored periodically by ORNL health physics personnel. Personnel are "frisked" upon exit of the facility to detect the presence of radiologic contamination. The building is currently in surveillance and maintenance status. The future long-term use of this facility was uncertain at the time of the writing and the building has currently been removed from the IFDP. Inactive waste drains are reportedly plugged in contaminated areas to prevent inadvertent discharge of contamination beyond the facility. A groundwater monitoring program is in place to monitor contamination levels and migration in groundwater underlying WAG 1. The building is inspected for structural changes after each natural incident (earthquake, tornado, or other severe storm), fire and/or man induced activity which could cause cracking, failure, or deterioration of the facility and/or equipment that may allow contamination to be released. No such conditions have been reported for Building 3047.

Current actions being taken to prevent further release and ensure worker safety in Building 3047 are considered adequate given the current status and level of activity of the facility. 


\section{Other Environmental Authorities}

Is the release or threatened release potentially subject to other environmental statutory actions? If yes, please explain.

If paint is found to be lead-containing and samples fail the Toxicity Characteristic Leaching Procedure (TCLP) analysis, the building could qualify as a hazardous waste generator point under the Resource Conservation and Recovery Act (RCRA).

\section{Maintenance Actions}

Are maintenance actions necessary to eliminate potential threats to human health and the environment? If so, explain.

One potential hazard requiring a maintenance action was identified to be associated with Building 3047. That is, the diesel fuel leak associated with the emergency generator located adjacent to the northwest wall of the building. The area of fuel around the generator should be cleaned up and the source of the leak should be identified and repaired to prevent further release.

\section{Removal Actions}

Are Removal Actions necessary to eliminate immediate threats to human health and the environment? If so, explain.

No imminent hazards requiring removal actions per $40 C F R 300.415$ were identified to be currently associated with Building 3047.

\section{Remedial Site Evaluation}

\section{Is a Remedial Site Evaluation needed?}

Areas of radiologic contamination associated with Building 3047 have been identified and marked as appropriate. However, it is suspected that process and LLLW drains and associated piping may have leaked beneath the slab of the building as a result of past practices. As a result, it is recommended that some type of remedial investigation be performed to assess the condition of the soil in this area before conducting any S\&M or D\&D activities which involve disturbing the slab.

Asbestos containing material and PCB items have also been identified, marked and documented. No further remedial investigation involving these hazards is considered necessary given the current status and future plans of this facility.

Based on the age of the facility, painted surfaces are assumed to contain lead. Samples of the paint should be taken and analyzed to verify the presence of lead prior to conducting any S\&M or D\&D activities which may disturb these assumed areas.

\section{No Further Investigation}

\section{Is a finding of No Further Investigation appropriate? Please explain.}

A finding of No Further Investigation implies that a facility or area is free from hazardous substances or contaminants that may threaten human health and the environment. Since Building 3047 contains substances and materials which may become threatening if not properly controlled, handled and managed during the S\&M cycle, a finding of No Further Investigation is inappropriate in this case. 


\section{Additional Comments}

The following documents and databases were referenced for historical and hazard information related to Building 3047:

- Phase 1 Safety Documentation, Radioisotope Development Laboratory, Building 3047 - Hazard Screening, Document No. HS/3047/F/RI-16 (Rev. 1)

- Work Plan for the Isotopes Facilities Deactivation Project at Oak Ridge National Laboratory, Document No. ORNL/ER-249/R2.

- Building 3047 Occurrence Reports, 1989 to present.

- Site Characterization Summary Report for Waste Area Grouping 1 at Oak Ridge National Laboratory, Oak Ridge, Tennessee, Volumes 1 and 2, Document Nos. DOE/OR-1043/V1\&D1 and DOE/OR-1043/V2\&D1.

- ORNL Hazardous Material Information System Database.

- ORNL Drain System Survey Report for Building 3047.

The following personnel and offices were contacted and provided historical and current use/condition information for Building 3047:

- Mr. Karl Haff, Radiochemical Processing Department Head, ORNL Radiochemical Technology Section.

- Mr. Herman Phillips, Assistant Facilities Manager, ORNL Special Projects.

- Ms. Swati Wilson, Manager, ORNL Lead Management Program.

- Mr. Nathan Dunn, Hazardous Material Information System Office.

- Mr. Jade Thomas, ORNL Environmental Compliance Office.

- Mr. Joe Armento, ORNL Chemical Technology Division, Isotopes Facilities Shutdown Program.

The RmSE of this facility was conducted for LMES under contract by:

Advanced Sciences, Inc.

800 Oak Ridge Turnpike, Suite C-102

Oak.Ridge, TN

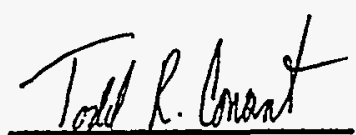

Evaluator's Signature

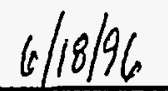

Date 
Building 3047

\section{STAIRS}
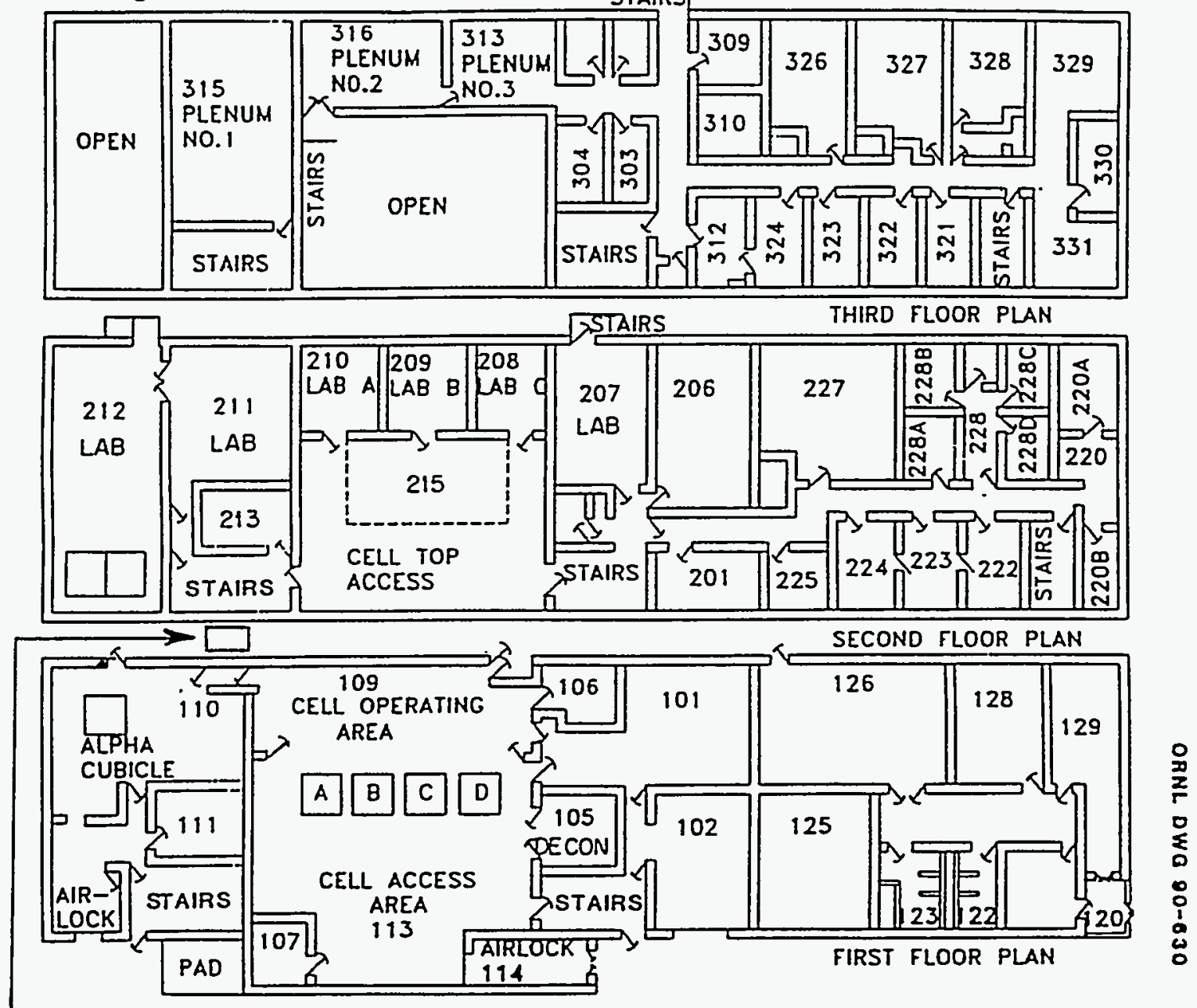

APPREXIHATE LOCATIION

OF LEAKING DIESEL

GENERATOR.

Fig. 17. Diagram of Building 3047. 
Plant: 3 Division:
Management Inventory Summary Report (by Building)

Department : Control Area: Building: 3047

\section{Room:}
Are
Area:
HẢ Rating
Inv status :
Haz Mat Grp Cd: Phy state:
พล Code:

Building: 3047

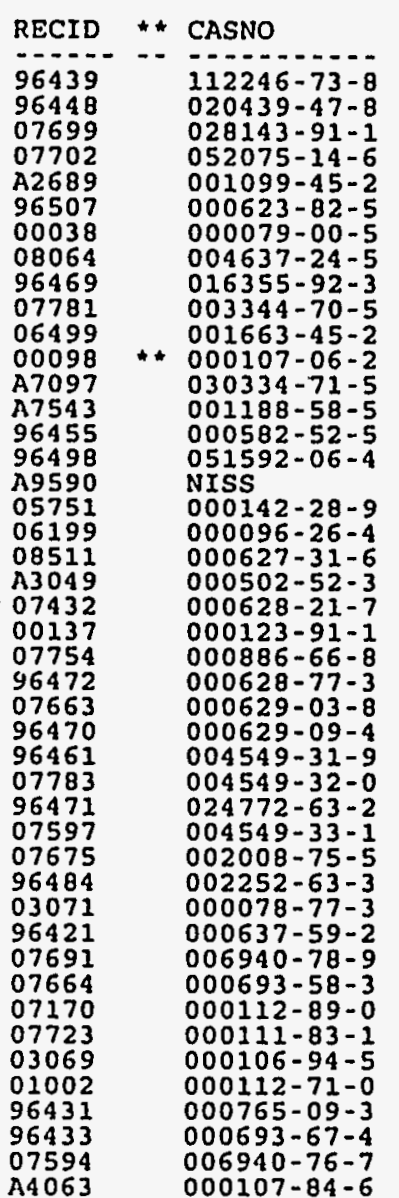

Material Name

(1)-

(IR, 2R) - $(-1-1,2-D I A M I N O C Y C L O H E X A N E$

IS, $2 S)-(+)-2$-AMINO - 1 - PHENY - 1,3 - PROPANEDIO

-2-METHYL - 5 - PHENYL - 2-OX

DENYLPOSPHORANE

- + +) - 3-METHYLADIOIC ACID

1,1-DIMETHOXY -N, N-DIMETHYLMETHANAMINE

1,10-DI IODODECANE

1,2 -BIS (DIPHENYLPHOSPHINO) ETHANE, $97 \%$

, 2-DICHLOROETHANE

1,2 -DIPALMITOYL-SN-GLYCEROL

1 , 2:5,6-DI-O-ISOPROPYLIDENE-A-D-GLUCOFURANOSE

$1,3,5(10), 16-E S T R A T E T R A E N-3,17$-DIOL 17-ACETATE, 3 -

1,3 -DIHYDROXY-2-PROPANONE

1,3 -DI IODOPROPANE

1, 3-DIPALMITIN

1,4 -DIOXANE

1,4 -DIPHENYLBUTADIYNE

, 5-DI IODOPENTANE

1, 6-DIBROMOHEXANE

1,6 -DIIODOHEXANE
1,7-DIBROMOHEPTANE
$1,8-D I B R O M O O C T A N E$

1,8-DIIODOOCTANE

1,9-DIBROMONONANE

1 - (2-CHLOROETHYL) PI PERIDINE MONOHYDROCHLORIDE

1- (4 - FLUOROPHENYL) PI PERAZINE

1-BROMO-2-METHYLPROPANE

1 - BROMO - 3 - PHENYLPROPANE
1 - BROMO-4 - CHLOROBUTANE

1 -BROMONONANE

- BROMOOCTADECANE

- BROMOOCTANE

-BROMOTETRADECANE

1 -BROMOTRIDECANE

-BROMOUNDECANE

1-CHLORO-3-IODOPROPANE
1 -CHLORO-3-METHYLAUTANE

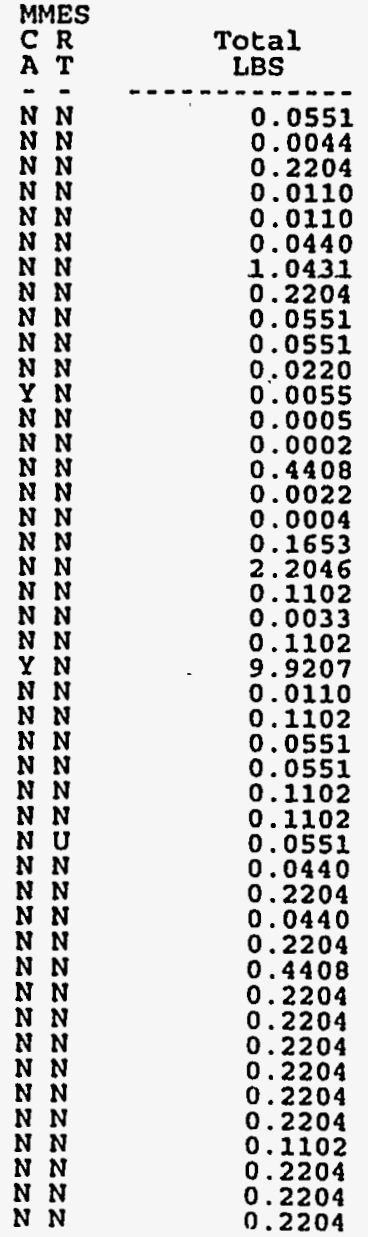

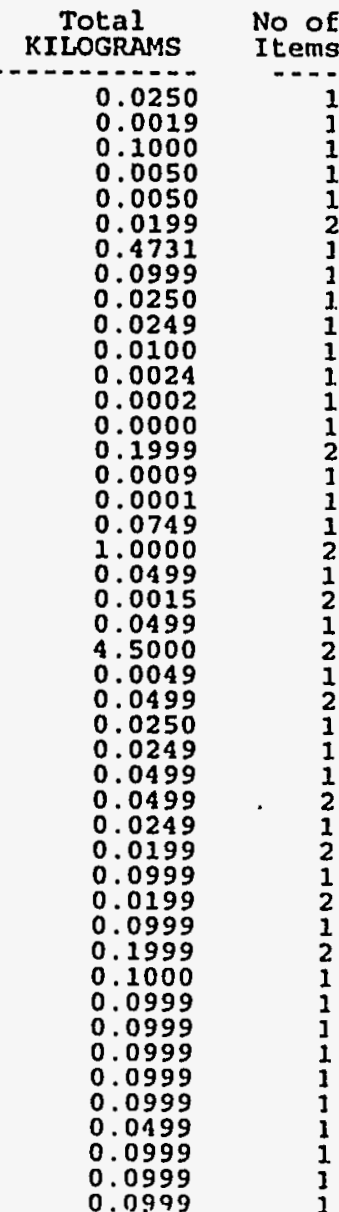


WA Code:

\begin{tabular}{|c|c|}
\hline $\begin{array}{l}\text { B3404 } \\
B 3405 \\
B 3403 \\
B 3402 \\
B 3401 \\
B 4101 \\
05851 \\
08007 \\
05769 \\
06206 \\
A 2629 \\
01021 \\
96525 \\
96527 \\
A 2665 \\
07672 \\
96432 \\
07805 \\
96512 \\
B 3358 \\
83444 \\
96531 \\
A 2675 \\
06124 \\
A 2684 \\
08375 \\
07888 \\
07499 \\
96558 \\
03117 \\
96473 \\
07799 \\
07750 \\
06177 \\
03128 \\
01123 \\
07786 \\
07696 \\
03154 \\
06941 \\
07855 \\
A 6762 \\
96497 \\
A 4683 \\
03214 \\
A 2680 \\
06086 \\
06087 \\
96550 \\
84034\end{array}$ & 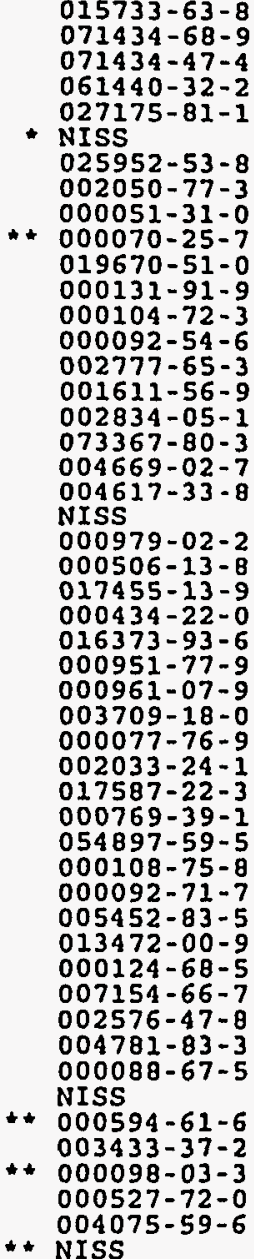 \\
\hline
\end{tabular}

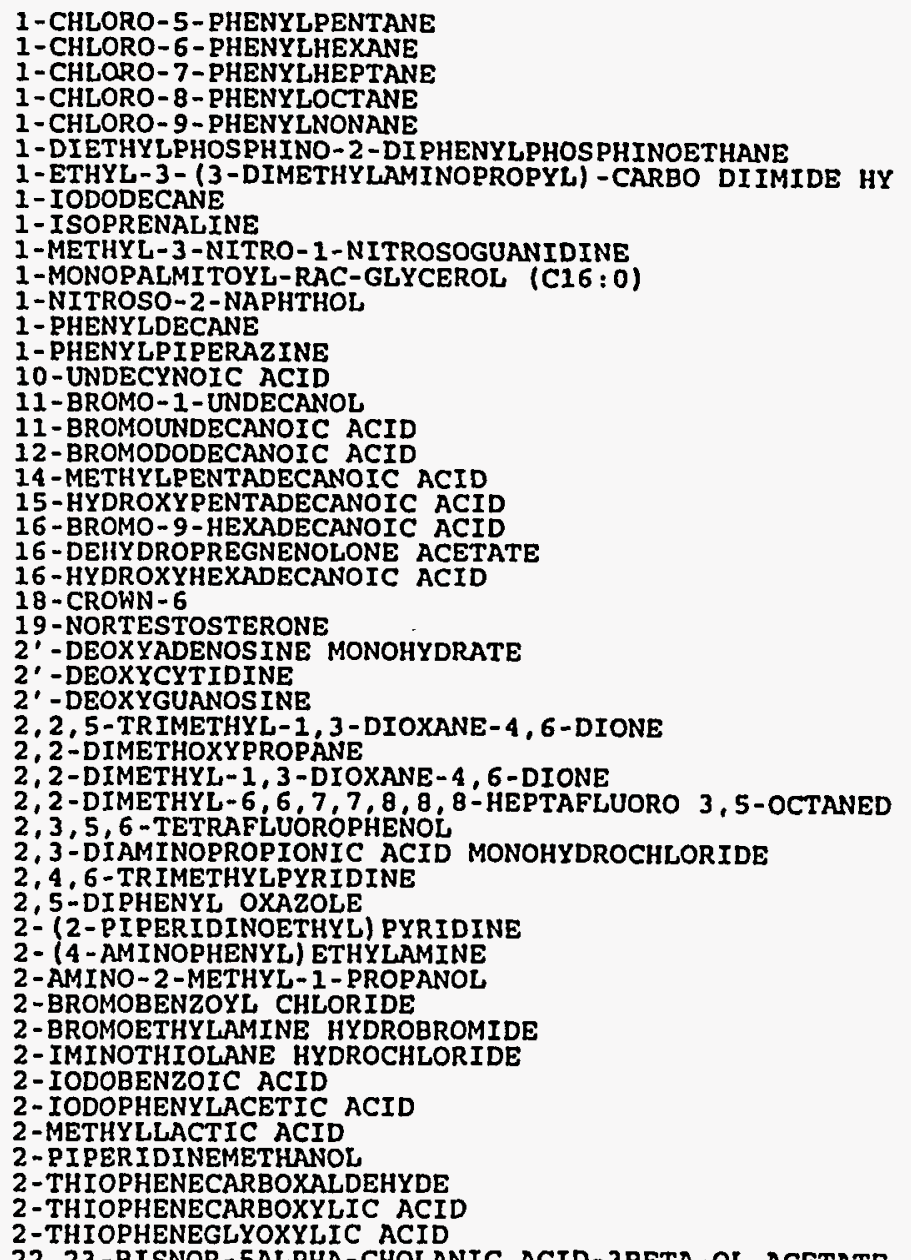

Cont Type Cd:

* indicates MSDS is not available

$\begin{array}{ll}0.0100 & 1 \\ 0.0050 & 1 \\ 0.0050 & 1 \\ 0.0050 & 1 \\ 0.0200 & 2 \\ 0.0010 & 1 \\ 0.0049 & 1 \\ 0.0999 & 1 \\ 0.0000 & 1 \\ 0.0249 & 1 \\ 0.0021 & 2 \\ 0.1998 & 2 \\ 0.0249 & 1 \\ 0.1000 & 1 \\ 0.0100 & 1 \\ 0.0599 & 2 \\ 0.1998 & 2 \\ 0.0149 & 2 \\ 0.0000 & 2 \\ 0.0250 & 1 \\ 0.0020 & 2 \\ 0.0249 & 1 \\ 0.0250 & 1 \\ 0.0250 & 1 \\ 0.0100 & 1 \\ 0.0002 & 1 \\ 0.0000 & 1 \\ 0.0000 & 1 \\ 0.0249 & 1 \\ 0.5000 & 1 \\ 0.0249 & 1 \\ 0.0500 & 1 \\ 0.0250 & 1 \\ 0.0050 & 1 \\ 0.1000 & 1 \\ 0.1998 & 2 \\ 0.0099 & 1 \\ 0.0299 & 3 \\ 0.5000 & 1 \\ 0.0099 & 1 \\ 0.1000 & 1 \\ 0.0000 & 1 \\ 0.0999 & 1 \\ 0.0010 & 1 \\ 0.1998 & 3 \\ 0.0250 & 1 \\ 0.1000 & 1 \\ 0.1000 & 1 \\ 0.0199 & 2 \\ 0.0030 & 1 \\ & \end{array}$


Plant: 3 Division

Date Expiration:

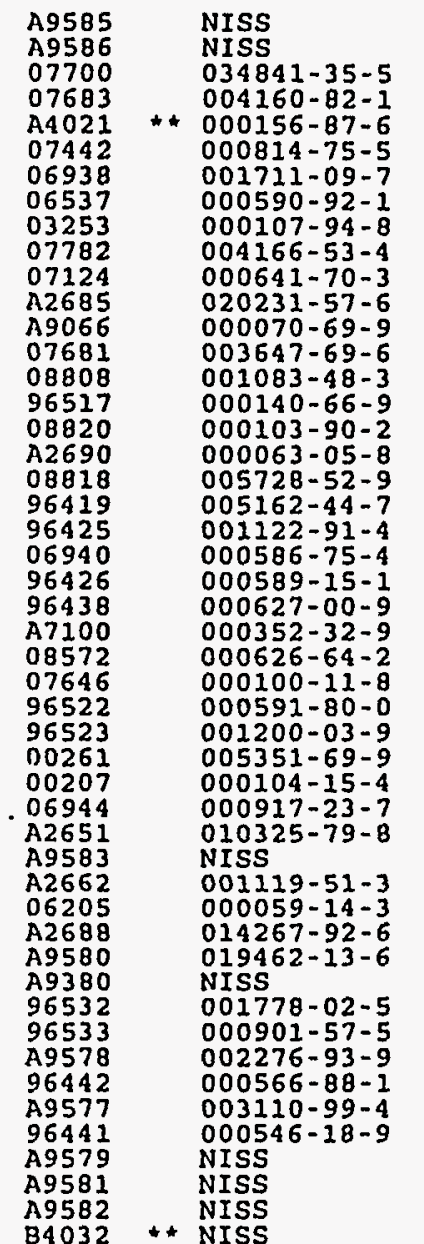

Control Area: Building: 3047

Room:

Area:

WA Code:
23-24-BISNOR-5-CHOLENIC ACID-3B-OL ACETATE
$23-24-B I S N O R-5$-CHOLENIC ACID-3B-OL METHYL

23-24-BISNOR-5-CHOLENIC ACID-3B-OL METHXL ESTER

3,3-DIMETHYLGLUTARIC ANHYDRIDE

3-AMINO-1-PROPANOL

3-BROMO-2-BUTANONE

3-BROMOPROPIONIC ACID

3-CHLOROPROPIONIC ACID

3B-HYDROXYCHOL-5-EN-24-OIC ACID METHYL ESTER

$4 \cdot$ - AMINOPROPIOPHENONE

4 - (2-CHLOROETHYL) MORPHOLINE HYDROCHLORIDE

4 - ( P-NITROBENZYL) PYRIDINE

- TERT-OCTXL) PHENOL

4-ANDROSTENE-3.17-DIONE

4-BIPHENYLACETIC ACID

4 -BROMO-1-BUTENE

4-BROMOBENZOYL CHLORTDE

4-BROMOBENZYL BROMIDE

4-CHLOROBUTYRIC ACID

4 - FLUOROTOLUENE

4-HYDROXYPYRIDINE
4-NITROBENZYL BROMIDE

4 - PENTENOIC ACID

4-PHENOXYBUTYL BROMIDE

4-PHENYLTHIOSEMICAREAZIDE

-TOLUENESULFONIC ACID

5,10,15, 20-TETRAPHENYL-21H, 23H-PORPHINE

5-ANDROSTEN-3B-OL; 17B-CARBOXYLIC ACID METHYL ESTE

5-BROMO-2,-DEOXYURIDINE

5-CHIORO 2 DENTHE

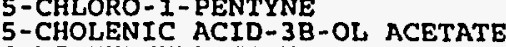

5-METHYLHYDANTOIN

5-PREGNEN-3-B-OL-20-ONE ACETATE

5-PREGNENE-3-B-20-B-DIOL

5A-CHOLANIC ACID-3B-OL

5A-CHOLESTAN-3-ONB

SB-CHOLAN-24-3L

5B-CHOLANIC ACID-3A, 12A-DIOL DIACETATE

5B-CHOLANIC ACID-3A, 12A-DIOL DIACETATE METHYL ESTE 5B-CHOLANIC ACID-3A, 12A-DIOL N-(CARBOXYMETHYL) - AMI LAN-24-IODO

B4033 * NISS

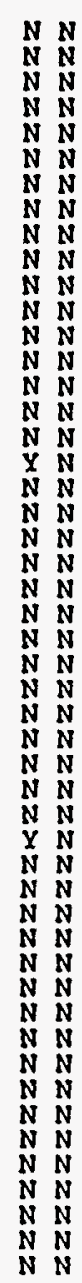

N
Cont Type Cd:
0.0250

0.0100

0.1998

0.2499

0.0499

0.0249

0.0250

0.0996
0.0498

0.0230

0.0500

0.0999

0.5000

0.0498

0.0100

0.0099

0.0099

0.0999

0.0299

0.0249

0.0999

0.0249

0.0500

0.1009

0.0100

0.0100

0.0500

0.0010

0.0967

0.0033
0.0100

0.0249

0.0115

0.0049

0.0001

0.0138

0.0050

0.0030

0.0000

0.0250

* indicates MSDS is not available 
Department: Control Area: Building: 3047 Room:

Area:

WA Code:

Date Expiration:

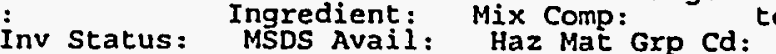

Phy State: Pressure Cd: Rating:

Cont Type Cd:

\begin{tabular}{|c|c|c|}
\hline $\begin{array}{l}96420 \\
05719 \\
96444 \\
07462 \\
09361 \\
07677 \\
07697 \\
00145 \\
03321 \\
00015 \\
07679 \\
96395 \\
00677 \\
00024 \\
00683 \\
01706 \\
90710 \\
05771 \\
17728 \\
07312 \\
06548 \\
00031 \\
96397 \\
94664 \\
09621 \\
A 4659 \\
08175 \\
A 3183 \\
96399 \\
03359 \\
96400 \\
00743 \\
96422 \\
07745 \\
14017 \\
00269 \\
05796 \\
00355 \\
00356 \\
06477 \\
00357 \\
A 4024 \\
87294 \\
\text { A7664 } \\
00273 \\
06390 \\
00363 \\
00364 \\
00366 \\
00367\end{array}$ & 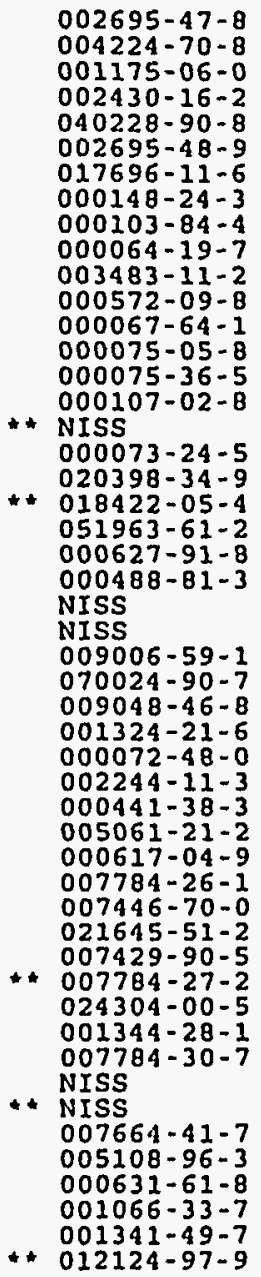 & 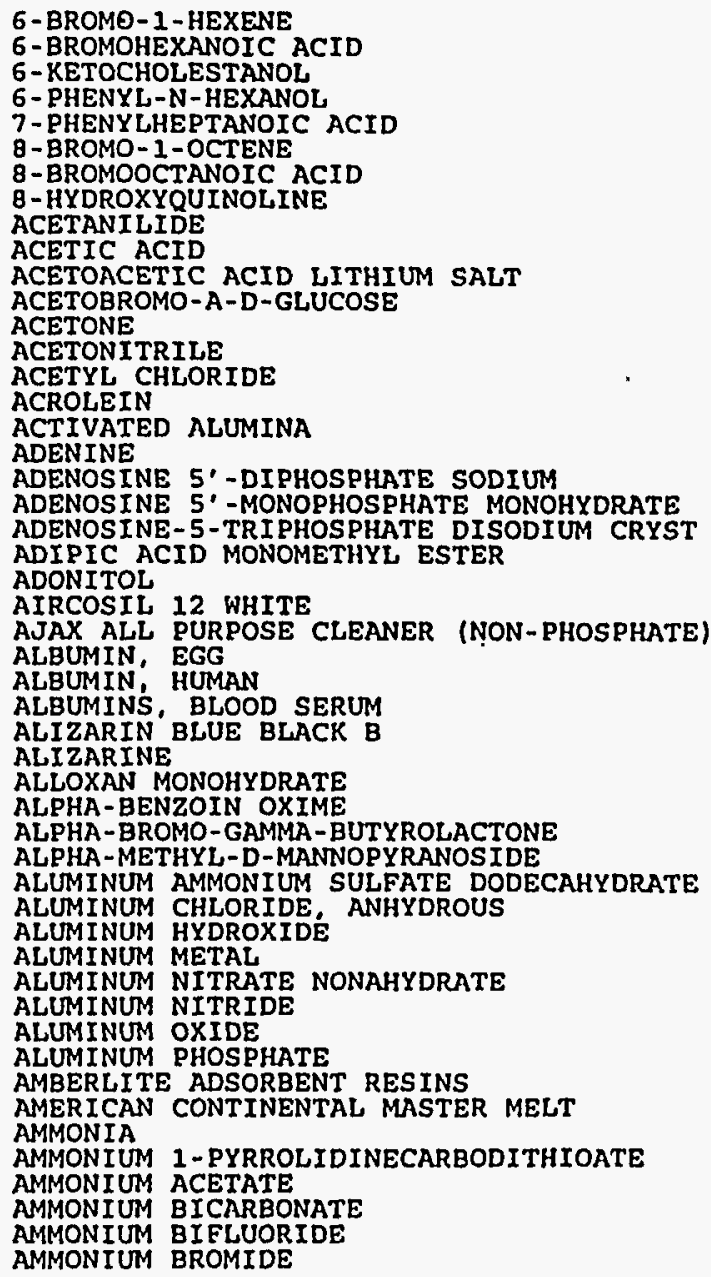 \\
\hline
\end{tabular}

$N$
$N$
$N$
$N$
$N$
$N$
$N$
$N$
$N$
$N$
$N$
$N$
$N$
$N$
$N$
$N$
$N$
$N$
$N$
$N$
$N$
$N$
$N$
$N$
$N$
$N$
$N$
$N$
$N$
$N$
$N$
$N$
$N$
$N$
$N$
$N$
$N$
$N$
$N$
$N$
$N$
$N$
$N$
$N$
$N$
$N$
$N$
$N$
$N$
$N$
$N$
$N$
$N$
$N$
$N$
$N$
$N$
$N$
$N$
$N$
$N$
$N$
$N$
$N$
$N$
$N$
$N$
$N$
$N$
$N$
$N$
$N$
$N$
$N$
$N$
$N$
$N$
$N$
$N$
$N$
$N$
$N$

0.1320

0.1102

0.0110

0.0330

0.0440

0.2204

25.7847

0.0110

0.8686

12.2906

1.2023

3.3069
0.0573

0.0002

0.0110
0.0088

0.0088
0.1102

0.0110

0.0625
31.5000

0.0022

0.2446

0.0220

0.0220
0.0220

0.0220
0.2204

0.2204
0.2201

0.2204

5.2046
5.1750

2.2046
10.3069

10.3069
26.5345

26.5345
2.2046

2.2046
12.9718

12.9718
1.1023

3.4250
50.0717

30.071

0.1102

5.0705

1. 1023

AMONIM BROMIDE

1.1023

$\begin{array}{rr}0.0599 & 6 \\ 0.0500 & 2 \\ 0.0049 & 1 \\ 0.0099 & 1 \\ 0.0150 & 2 \\ 0.0249 & 1 \\ 0.0199 & 2 \\ 0.1000 & 1 \\ 0.0249 & 1 \\ 11.6956 & 4 \\ 0.0049 & 1 \\ 0.0499 & 1 \\ 0.3939 & 1 \\ 5.5749 & 2 \\ 0.2499 & 1 \\ 0.5000 & 1 \\ 1.5000 & 2 \\ 0.0259 & 2 \\ 0.0000 & 1 \\ 0.0050 & 5 \\ 0.0039 & 2 \\ 0.0500 & 2 \\ 0.0049 & 1 \\ 0.0283 & 1 \\ 14.2883 & 1 \\ 0.0009 & 1 \\ 0.0049 & 1 \\ 0.1107 & 3 \\ 0.0099 & 1 \\ 0.0099 & 1 \\ 0.0099 & 1 \\ 0.0999 & 1 \\ 0.1000 & 10 \\ 0.0999 & 1 \\ 2.3605 & 1 \\ 2.3462 & 13 \\ 1.0000 & 1 \\ 4.6745 & 10 \\ 12.0358 & 5 \\ 1.0000 & 1 \\ 5.8836 & 11 \\ 0.5000 & 1 \\ 1.5534 & 3 \\ 22.7121 & 1 \\ 13.6115 & 1 \\ 0.0199 & 2 \\ 2.2999 & 1 \\ 0.5000 & 1 \\ 3.2675 & 6 \\ 0.5000 & 1 \\ & \end{array}$

$\therefore$ indicates MSDS is not available 
Plant: 3 Division:

Date Expiration:
Department :

Control Area: Bullding: 3047

Ingredient: Mix Comp:

Room:

Area :

Hizz Rating:

Page:
Installation: 5
ORNI,

Wh Code:

\begin{tabular}{|c|c|c|}
\hline $\begin{array}{l}00369 \\
00370 \\
00287 \\
02221 \\
02220 \\
A 3269 \\
A 7102 \\
00372 \\
00374 \\
00375 \\
00262 \\
00378 \\
06098 \\
07434 \\
00380 \\
00291 \\
15508 \\
A 2323 \\
00007 \\
00383 \\
00384 \\
01726 \\
87736 \\
94089 \\
01730 \\
00311 \\
92876 \\
07784 \\
A 3061 \\
00386 \\
00303 \\
00306 \\
00293 \\
00454 \\
B 0565 \\
07762 \\
00001 \\
06348 \\
A 7095 \\
00603 \\
00747 \\
00748 \\
00078 \\
00079 \\
96416 \\
06037 \\
03544 \\
07748 \\
00391 \\
07744\end{array}$ & 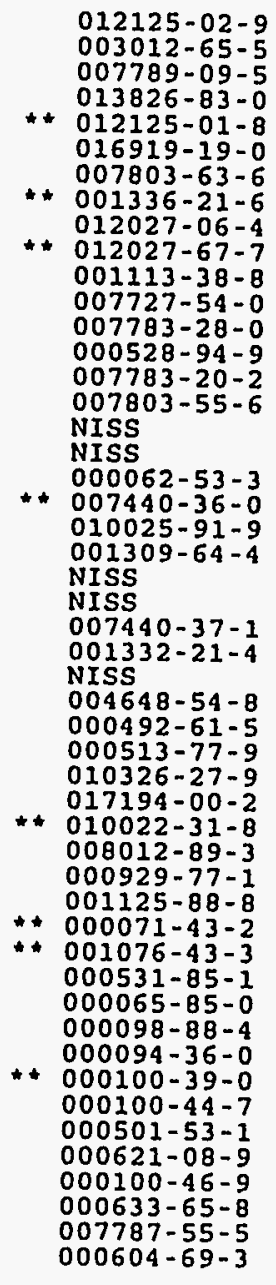 & 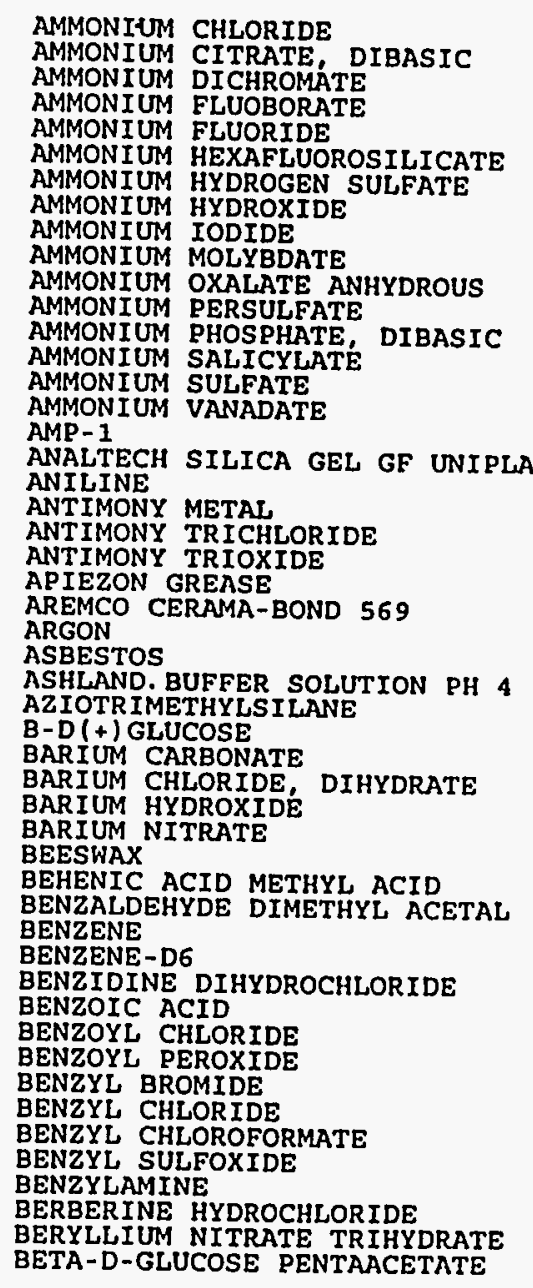 \\
\hline
\end{tabular}

- indicates MSDS is not available

- indicates MSDS updated within last three months

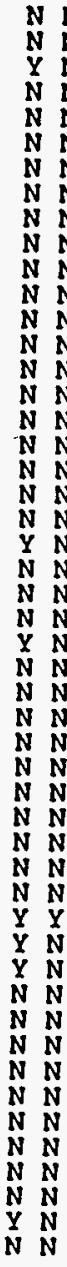

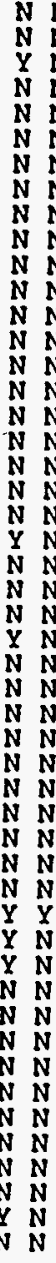
Cont Type Cd:

\begin{tabular}{|c|}
\hline $\begin{array}{l}1.6104 \\
1.9070 \\
0.5000 \\
2.3605 \\
1.4535 \\
0.5000 \\
0.4535 \\
4.7674 \\
0.3629 \\
0.3259 \\
3.2675 \\
0.9535 \\
0.5000 \\
0.2499 \\
1.0000 \\
0.7263 \\
1.5000 \\
0.4535 \\
1.4071 \\
0.5000 \\
0.3629 \\
0.5000 \\
0.0250 \\
0.0141 \\
5.5423 \\
0.4000 \\
1.0000 \\
0.0250 \\
0.0100 \\
0.9520 \\
1.9070 \\
2.8605 \\
1.8605 \\
0.4535 \\
0.0099 \\
0.1999 \\
4.0050 \\
0.0049 \\
0.1000 \\
0.1249 \\
0.2498 \\
0.1499 \\
0.0999 \\
0.0499 \\
0.2999 \\
0.0250 \\
0.5000 \\
0.0495 \\
0.0999 \\
0.1998\end{array}$ \\
\hline
\end{tabular}



Installation: ORNI

Date Expiration:

\begin{tabular}{|c|c|c|}
\hline $\begin{array}{l}00203 \\
82250 \\
95639 \\
93224 \\
93223 \\
A 4106 \\
A 4108 \\
A 0833 \\
14107 \\
16571 \\
93342 \\
93379 \\
93543 \\
92434 \\
92390 \\
A 4394 \\
96440 \\
06688 \\
00392 \\
06841 \\
00332 \\
06045 \\
00395 \\
96423 \\
A 6942 \\
96424 \\
00338 \\
83616 \\
86344 \\
89878 \\
00046 \\
00397 \\
A 4027 \\
00400 \\
00401 \\
06406 \\
17113 \\
00404 \\
00406 \\
00407 \\
00409 \\
00410 \\
00692 \\
00786 \\
00151 \\
07168 \\
07931 \\
07658 \\
07623 \\
00790\end{array}$ & $\begin{array}{l}\text { 000103-63-9 } \\
\text { NISS } \\
\text { NISS } \\
\text { NISS } \\
\text { NISS } \\
\text { NISS } \\
\text { NISS } \\
\text { NISS } \\
\text { NISS } \\
\text { NISS } \\
\text { NISS } \\
\text { NISS } \\
\text { * NISS } \\
\text { NISS } \\
\text { NISS } \\
\text { NISS } \\
000821-48-7 \\
007787-60-2 \\
00744-69-9 \\
058632-95-4 \\
010043-35-3 \\
000109-63-7 \\
007726-95-6 \\
002032-35-1 \\
\text { NISS } \\
022118-09-8 \\
000076-59-5 \\
\text { NISS } \\
\text { NISS } \\
\text { NISS } \\
010108-64-2 \\
007440-43-9 \\
010124-36-4 \\
000471-34-1 \\
\text { * } 010043-52-4 \\
010035-04-8 \\
012007-99-7 \\
007770-54-3 \\
\text { * } \\
007440-70-2 \\
010124-37-5 \\
001305-78-8 \\
007778-18-9 \\
\text { * } 007440-44-0 \\
000075-15-0 \\
000558-13-4 \\
009000-11-7 \\
009001-05-2 \\
000274-07-7 \\
009004-34-6 \\
009004-35-7\end{array}$ & 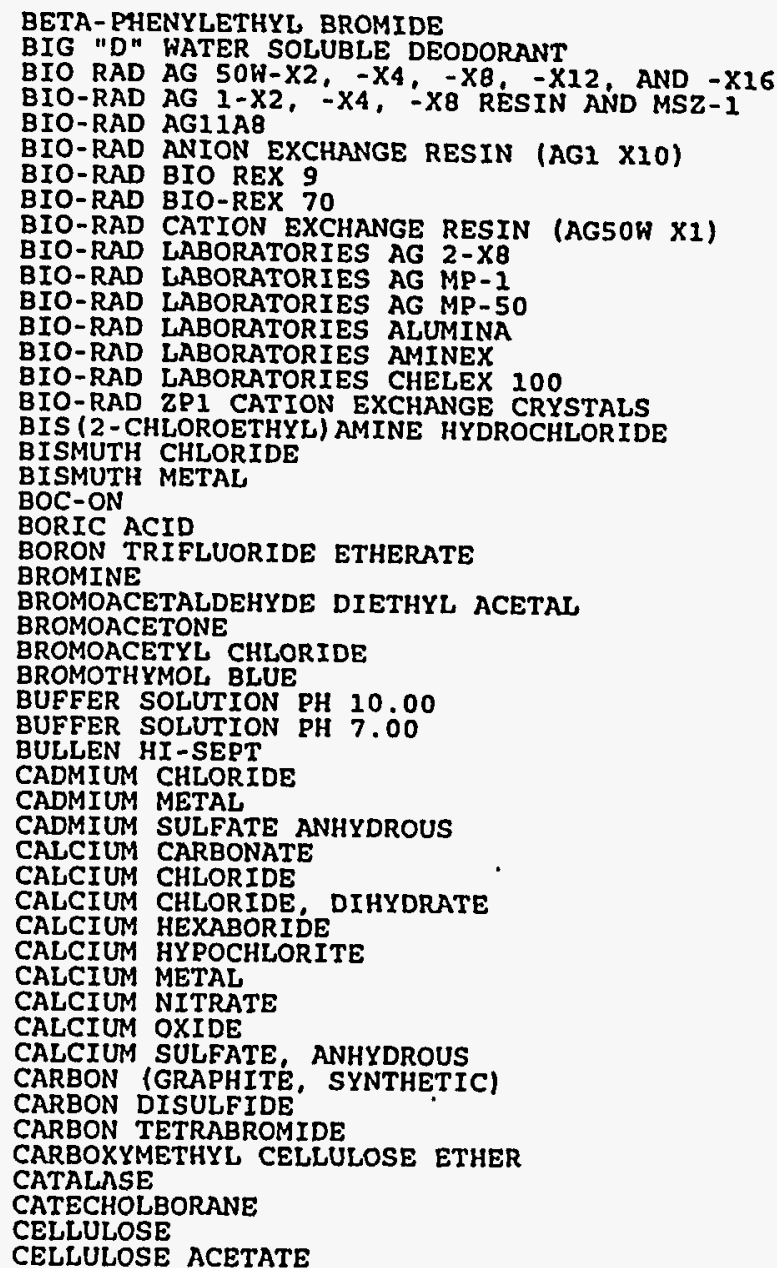 \\
\hline
\end{tabular}
Control Area :

Room:

Inv status: MSDS Avail:

HS D HATER SOLUBLE DEODORANT

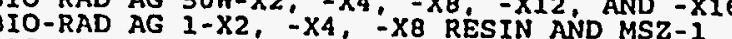

:

Hiz Rating

Temp cd: Cont Type Cr:

wh Code:

HYDROCHLORIDE

ETHERATE

ROMOACETALDEHYDE DIETHYL ACETAL

BROMOACETYL CHLORIDE

BUFFER SOLUTION PH 10.00

$N$
$N$
$N$
$N$
$N$
$N$
$N$
$U$
$U$
$U$
$U$
$N$
$N$
$U$
$N$
$N$
$N$
$N$
$N$
$N$
$N$
$N$
$N$
$N$
$N$
$U$
$N$
$N$
$N$
$N$
$N$
$N$
$N$
$N$
$N$
$N$
$N$
$N$
$N$
$N$
$N$
$N$
$N$
$N$
$N$
$N$
$N$
$N$
$N$
$N$
$N$
$N$
$X$
$X$
$X$
$Y$
$Y$
$N$
$N$
$N$
$N$
$N$
$N$
$N$
$N$
$N$
$N$
$N$
$N$
$N$
$N$
$N$
$N$
$N$
$N$
$N$
$N$
$N$
$N$
$N$
$N$
$N$
$N$
$N$
$N$
$N$
$N$

0.4409

0.1999

18.7381

9.5954

0.4535

0.9070

0.4535
0.9070

0.4535

0.4535
1.4535

1.4535
0.9535

2.4535
1.8999

2.2675

0.6000

0.0249
0.0999

0.0999

1.0249

1.5000
0.5000

0.0999

0.0250
0.1633

0.1999

0.0009

1.0000

4.731 ?

0.3629

0.0999

1.4535
1.4535

0.5000

0.1500

0.2499

2.3140

1.9570
2.3605

0.5000

0.5000

0.0999

0.10

0.1998

0.5000
1.0000

$\therefore$ indicates MSDS is not available 
Plant: 3 Division: Item ID:

Date Expiration: 00412

Department : gement Inventory Summary Report (by Building)

Installation: ORNL

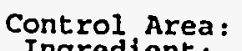

พA Code: 03689 00413 06217 07049 00416 06558 00792 A0869 07139 06392 96436 A4028 00173 00016
05914
07685 07685
00308 07670 05772 03796
$A 2649$ 07151
00340 00340
00319 00286 00417 02295
01813 03821 00421 00422 95221 86089 02316 0042 80430 81444
02326
00257 00277 06450 A4026 05928
$A 4661$ A4661 A3 048
06693

* NISS$$
\text { NISS }
$$
$007440-50-8$ $001317-38-0$ 000548 $00548-62-9$ $007758-98-4$ $007787-70-4$ $000108-85-0$ $000065-46-3$ $034393-59-4$ $000071-30-7$

* indicates MSDS is not available

CERIC AMMONIUM NITRATE

CERIUM OXIDE

CERIUM (IV) SULFATE

CESIUM NITRATE

CESIUM SULFATE

CETYL IODIDE

CETYLITE INDUSTRIES CETYLCIDE

CHARCOAL, ACTIVATED

CHLOROACETONE

CHLOROACETYL CHLORIDE

CHLOROFORM

CHLOROFORM-D

CHLOROMETHYLTRI PHENYLPHOSPHONIUM CHLORIDE

CHLOROPLATINIC ACID

CHLOROTRIMETHXLGERMANE

CHLOROTRIMETHYLSILANE

CHOLESTERY

CHOLESTERYI BROMIDE

CHROME BLACK T

CHROMIC.ACID

CHROMIC NITRATE NONAHYDRATE

CHROMIUM (III) OXIDE

CIS-PLATIN

COBALT METAL

COBALT NITRATE HEXAHYDRATE

COBALT II) CHLORIDE HEXAHYDRATE

COLD KILL WASP/HORNET KILLER $\$ 297852$

COMPERSED AIR

COPPER METAL

COPPER (II) OXIDE

CRC $2-26$ (AEROSOL)

CUPRIC CHLORIDE

CUPRIC SULFATE

CUPROUS BROMIDE

CYCLOHEXYL BROMIDE

CYTIDINE

CYTIDINE 5' -TRIPHOSPHATE SODIUM TYPE I
CYTIDINE-5-DIPHOSPHATE TYPE I SODIUM SALT

* indicates MSDS is not available
CERIUM (III) NITRATE, HEXAHYDRATE

CHELIDONIC ACID MONÓHYDRATE
Room:
HAZ Class: HÁ
Phy state: Rating:

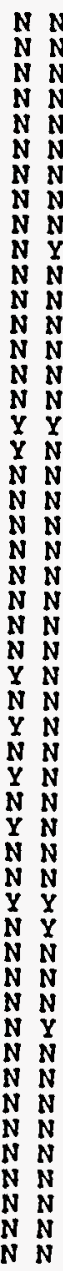

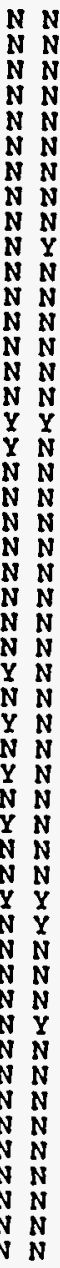

2.2046

1.0000

1.5621

1.1023

0.0551

0.0551

3.2859

7.2046

0.0551

10.0000
0.2204

0.1102
10.4542

10.4542
0.2644

0.1102

0.0110

0.0110

1.1023
0.0110

0.0110

0.0220

5.5114
0.2204

5.2046

0.0000

23.8184

0.8002

1.1023

2.3470
27.1391

1.102

2.2046
3.2046

0.0651
0.2204

2.1023

2.2046

0.2204

0.0002

0.0000

0.0000

Cont Type Cd

1.0000
0.4535

0.7080

0.5500

0.0250

0.5000

0.0249
1.4904

1.4904
7.2564

3.2675

4. 5359

0.050

4.7419
0.1199

0.1199

0.0036

0.5000

0.5000

0.0049

0.0099

2.4999

0.0999
2.3605

1.2000

10.8039

0.3629

0.0999

0.5000

$1 \frac{1}{10} .0646$

12.3102

0.5000

1.0000
1.4535

0.0295

0.9535

1.0000

0.0999

0.0749

0.0000

0.0000
0.0000
0.0009 
Plant: 3 Division: Department: Control Area: Building: 3047 Room

WA Code:

Item ID:

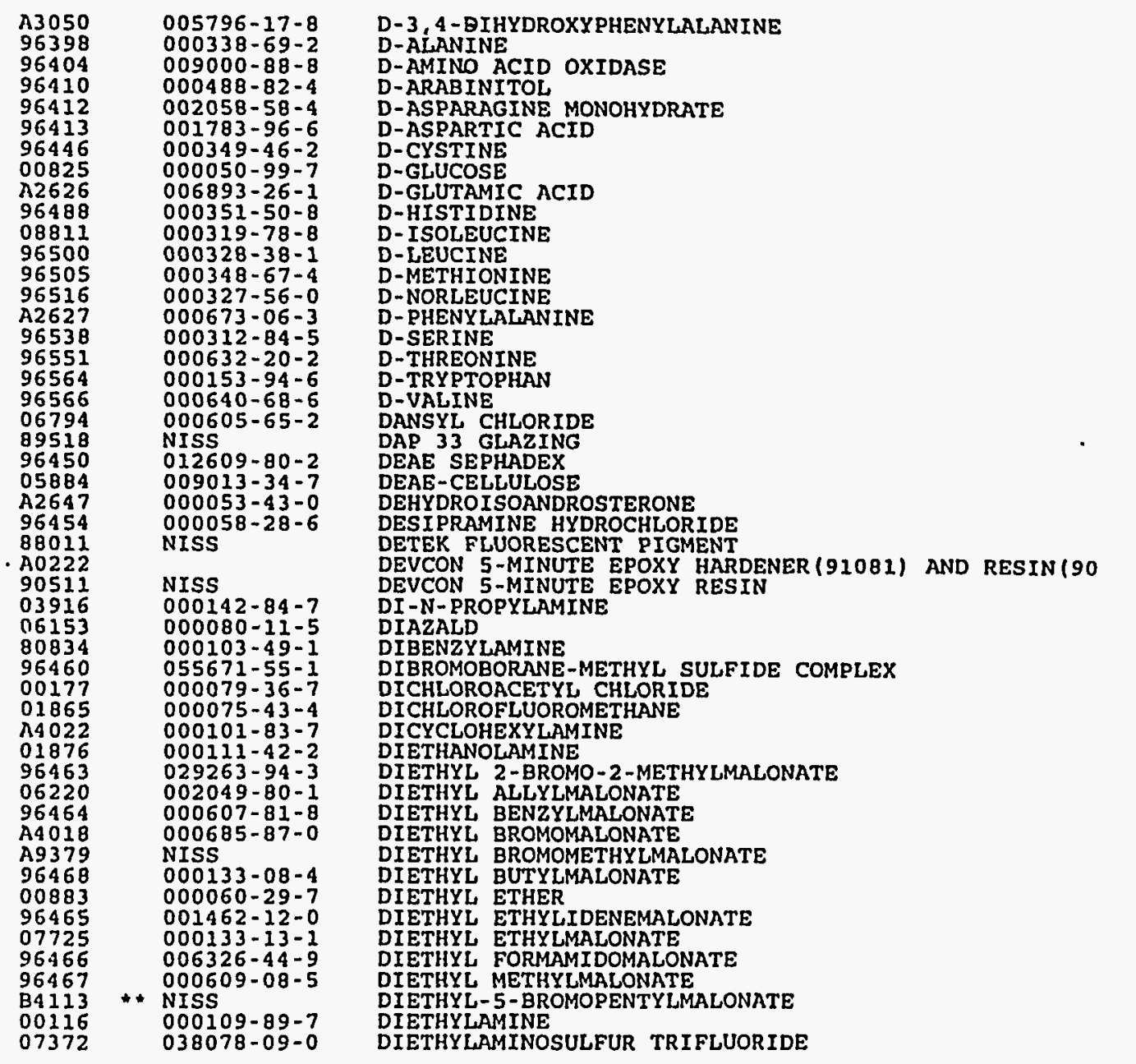

$N$
$N$
$N$
$N$
$N$
$N$
$N$
$N$
$N$
$N$
$N$
$N$
$N$
$N$
$N$
$N$
$N$
$N$
$N$
$N$
$N$
$N$
$N$
$N$
$N$
$N$
$N$
$N$
$N$
$N$
$N$
$N$
$N$
$N$
$N$
$N$
$N$
$Y$
$N$
$N$
$N$
$N$
$N$
$N$
$N$
$N$
$N$
$N$
$N$
$N$
$N$
$N$
$N$
$N$
$N$
$N$
$N$
$N$
$N$
$N$
$N$
$N$
$N$
$N$
$N$
$N$
$N$
$N$
$N$
$N$
$N$
$N$
$N$
$N$
$N$
$N$
$N$
$N$
$N$
$N$
$N$
$N$
$N$
$N$

0.0002
0.0002
0.0022
0.0022
0.0002
0.0002
0.0002
5.7540
0.0002
0.0002
0.0002
0.0002
0.0002
0.0002
0.0002
0.0002
0.0002
0.0002
0.0002
0.0044
4.5899
0.2204
1.6534
0.0551
0.0220
0.2204
0.7161
0.0651
0.2204
0.2204
0.2204
0.2204
0.2204
2.5648
0.5511
0.2204
0.0220
0.1653
0.0551
0.0551
0.1210
0.4408
0.7863
0.0110
0.2204
0.0551
0.4408
0.0440
2.3658
0.1102

0.0000

0.0000

0.0009
0.0009

0.0000

0.0000

0.0000
2.6099

0.0000

0.0000

0.0000

0.0000

0.0000

0.0000

0.0000

0.0019

2.0819
0.0999

0.7500

0.0250

0.0099
0.0999

0.3245

0.0999

0.0999

0.0999
0.0999

0.0999

1.1634

0.2499

0.0099

0.0749

0.0249

0.0249

0.1999

0.3566

0.0049

0.0999

0.1999

0.0200

1.0730
0.0499

indicates MSDS is not available
indicates MSDS updated within last three months 
Plant: 3 Division:

Date Expiration:
Department : Control Area:
Room: Inv status: MSDS Avali: Maz Mat Grp Cd: Inv status: MSDS Avail: Maz Mat Grp Cd:

$05295+020624-25-3 \quad$ DIETHYEDITHIOCARB

03566 000111-96-6 DIETHYLENE GLYCOL DIMETHYL ETHER

$001605-53-4$

NISS

90685 NISS

$96443000080-97-7$

$000080-97-7$

$000108-18-9$

$000077-78-1$

$000128-04-1$

$000068-12-2$

$000095-45-4$

$000577-11-7$

$001666-13-3$

$032294-60-3$

$007789-00-6$

$003483-12-3$

$000060-10-6$

$001314-36-9$

$002507-55-3$

$000764-67-0$

$000629-22-1$

$073548-70-6$

$001927-25-9$

$005619-04-5$

$000123-01-3$

07668

07715

A5533

NISS

5494 NISS

A1304 * NISS

8601

82356

NISS

NISS

NISS

93211

NISS

89343

NISS

NISS

82358

89342

NISS

$000608-66-2$

DIETHYLNETRIAMINEPENTAACETIC ACID

DITS L

DIFCO AGAR, BACTO 0140

DIFCO MALTOSE 0168

DIISOBUTYLALUMINUM HYDRIDE

DIISOPROPYLAMINE

DIMETHYLDITHIOCARBAMIC ACID, SODIUM SALT HYDRATE

DIMETHYLFORMAMIDE

DIMETHYLGLYOXIME

DIOCTYL SODIUM SULFOSUCCINATE

TPHENYL DISELENIDE

(1)

DITHIOTHREITOL

DITHIZONE

IDIC ACID

DL-A-HYDROXYMARISTIC ACID

作

DL-A-PHOSPHATIDYL-DL-GLYCEROL-DI PALMITOYL AMMONIUM

DL-SERINE METHYL ESTER HCL

DL-THIOCTIC ACI

DOPAMINE CHLORIDE

DOW CHEMICAL DOWEX(R) 2X8, 50-100 MESH CL ANION E DOW CORNING SILICONE RUBBER PAINTABLE SEALANT 8644 DOW CORNING(R) 111 COMPOUND

DOW CORNING(R) 321 DRY FILM LUBRICANT - AEROSOL

DOW CORNING(R) 705 DIFFUSION PUMP FLUID

DOW CORNING(R) X5-8022 LIQUID SIL. RUBBER, PART

DOWEX (R) 1 -X8 20-50 MESH IONIC FORM CL

DOWEX (R) $21 \mathrm{~K}, 16-30$ MESH, CL ANION EXCHANGE RESIN

DOWEX (R) 50WX4, 50-100 MESH, H CATION EXCHANGE RES

DOWEX (R) 5OWXB, 100-200 MESH, H CATION EXCHANGE RE DRIERITE (R)
DULCITOL

- indicates MSDS is not available
indicates MSDS updated within last three months
Area:

Installation: ORNL

WA Code:

Cont Type Cd:

\begin{tabular}{|c|c|}
\hline $\begin{array}{l}0.2204 \\
8.8184 \\
0.5511 \\
0.2204 \\
1.1023 \\
0.0110 \\
0.2500 \\
0.2500 \\
0.2204 \\
0.0551 \\
0.2204 \\
2.2046 \\
1.1023 \\
6.6448 \\
0.4408 \\
7.4713 \\
1.1030 \\
0.0220 \\
1.0000 \\
0.0660 \\
0.0440 \\
2.1023 \\
0.0110 \\
0.0771 \\
0.1100 \\
0.0001 \\
0.0001 \\
0.0001 \\
0.0000 \\
0.0000 \\
0.6613 \\
0.3744 \\
0.0011 \\
0.0330 \\
0.0220 \\
3.0000 \\
0.1875 \\
0.3306 \\
0.1955 \\
1.4342 \\
1.1023 \\
1.4132 \\
1.0000 \\
1.0000 \\
4.2046 \\
1.1023 \\
1.0000 \\
2.1023 \\
23.1023 \\
0.0230\end{array}$ & $\begin{array}{r}0.1000 \\
4.0000 \\
0.249 \\
0.0999 \\
0.5000 \\
0.0050 \\
0.1133 \\
0.1133 \\
0.1000 \\
0.0249 \\
0.0999 \\
1.0000 \\
0.5000 \\
3.0139 \\
0.2000 \\
3.3888 \\
0.5003 \\
0.0099 \\
0.4535 \\
0.0299 \\
0.0200 \\
0.9535 \\
0.0050 \\
0.0348 \\
0.0499 \\
0.0000 \\
0.0000 \\
0.0000 \\
0.0000 \\
0.0000 \\
0.2999 \\
0.1699 \\
0.0004 \\
0.0149 \\
0.0099 \\
1.3605 \\
0.0850 \\
0.1500 \\
0.0887 \\
0.6506 \\
0.5000 \\
0.6407 \\
0.4535 \\
0.4535 \\
1.9070 \\
0.5000 \\
0.4535 \\
0.9535 \\
10.4770 \\
0.000\end{array}$ \\
\hline
\end{tabular}


Plant: 3 Division:

Item ID:

Date Expiration:

\begin{tabular}{ll}
93998 & NISS \\
88126 & NISS \\
95390 & NISS \\
A8435 & NISS \\
A3879 & NISS \\
08724 & $000149-32-6$ \\
A7099 & NISS \\
A2683 & $001624-62-0$ \\
05984 & $001239-45-8$ \\
00142 & $+000141-78-6$ \\
00022 & $000074-96-4$ \\
04082 & $000105-36-2$ \\
06724 & $000109-94-4$ \\
00166 & $000075-03-6$ \\
04075 & $00011-62-6$ \\
96480 & $004755-77-5$ \\
00919 & $000107-21-1$ \\
00917 & $000060-00-4$ \\
05794 & $+4001308-96-9$ \\
82765 & NISS \\
A1250 & NISS \\
90530 & $00194-12-3$ \\
83360 & $001944-12-3$ \\
00432 & $007783-83-7$ \\
00295 & $007705-08-0$ \\
00434 & $007782-61-8$ \\
00435 & $001309-37-1$ \\
00436 & $* 010028-22-5$ \\
00439 & $013478-10-9$ \\
00441 & $007782-63-0$ \\
96247 & $000067-73-2$ \\
96483 & 000067 \\
00932 & $002321-07-5$ \\
96530 & NISS \\
00014 & $000064-18-6$ \\
81193 & NISS \\
04149 & $012064-62-9$ \\
89329 & NISS \\
89856 & NISS \\
90311 & NISS \\
85495 & NISS \\
90544 & NISS \\
04159 & $009000-70-8$ \\
93275 & NISS \\
00442 & $001310-53-8$ \\
05774 & $000108-55-4$ \\
00936 & $+000056-81-5$ \\
00938 & $000056-40-6$ \\
96210 & NISS \\
06667 & $000073-40-5$ \\
& \\
\hline
\end{tabular}

Department :

Control Area:

Building: 3047

Room:

Area:

Class: HAZ Rating:

Page: 10
Installation: ORNL

WA Code: DUPONT. OMNIFLUOR (R) PREMIXED LSC POWDER
DUPONT PROTOSOL (R) TISSUE AND GEL SOLUBILIZER 作 450 WHITE- 1 GREASE EPO TEK 310, PART B RYTHRITOL

ESTRONE 3-METHYL ETHER

ETHIDIUM BROMIDE

ETHYL BROMIDE

ETHYI BROMOACETATE

ETHYL OLEATE

ETHYL OXALYL CHLORIDE

ETHYLENE GLYCOL

TETRAACETIC ACID

UROPIUM OXIDE

STICK U-26 U-75, U-12

FEL-PRO C5-A HIGH TEMPERATURE ANTISEIZE COMPOUNDD

FENOTEROL HYOROBROMIDE

FERRIC AMMONIUM SULFATE DODECAHYDRATE

ERRIC NITRATE, NONAHYDRATE

FERRIC OXIDE

FERTC SULFATE, ANHYDROUS

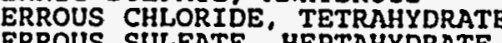

ISHER JET CLEAN GLASSWARE DETERGENT

TTONIDE

FOLIN \& CIOCALTEU'S PHENOL REAGENT (04392,00548,06

FORMULA 409 ALL PURPOSE CLEANER

GASOLINE, PREMIUM UNLEADED

GE RTV SILICONE RUBBER SENLANT, GE012

GE RTV SILICONE SEALANT

GE RTVIO2

GENERAL SERVICE (AEROSOL) COATING, 8010-00-515-248 GERMANIUM DIOXIDE

GLUTARIC

GRAPHIC CONTROLS HONEYWELL QUICK DRY INK \& TYPE 13

GUANINE

* indicates MSDS is not available
$N$
$N$
$N$
$N$
$N$
$N$
$N$
$N$
$N$
$N$
$N$
$N$
$N$
$N$
$N$
$N$
$N$
$N$
$N$
$N$
$N$
$N$
$N$
$N$
$N$
$N$
$N$
$N$
$N$
$N$
$N$
$N$
$N$
$N$
$\mathbf{N}$
$N$
$N$
$N$
$N$
$N$
$N$
$N$
$N$
$N$
$N$
$N$
$N$
$N$
$N$
$N$
$N$
$N$
$N$
$N$
$N$
$N$
$N$
$N$
$Y$
$N$
$N$
$N$
$N$
$N$
$N$
$N$
$N$
$N$
$Y$
$Y$
$N$
$N$
$N$
$N$
$N$
$N$
$N$
$Y$
$N$
$N$
$N$

0.1940
3.3069

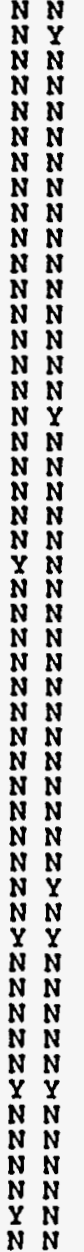

0.1234

0.0551

0.0110

0.0550

17.6368

0.5511

1.1023

0.4408
0.0022

1.0531

11.0230
1.1023

4. 2988

0.0837

0.6572
0.2314

1.6005

1.2984

3.3069
5.2046

1.1023

83.4528

0.1102

3.1878

0.6088

5.6592

8.3452
30.0000

1.3402

2.6672

1.1023

0.8475

0.220

4.2908

0.0022

0.0022
Cont Type Cd:

\begin{tabular}{rr}
0.0880 & 1 \\
1.5000 & 3 \\
1.0000 & 1 \\
0.0560 & 1 \\
0.0250 & 1 \\
0.0050 & 1 \\
0.0050 & 1 \\
0.0249 & 4 \\
0.0049 & 1 \\
8.0000 & 2 \\
0.2499 & 1 \\
0.2000 & 2 \\
0.5000 & 1 \\
0.1998 & 2 \\
0.0009 & 1 \\
0.0249 & 1 \\
5.0000 & 6 \\
0.5000 & 1 \\
1.9500 & 5 \\
0.0887 & 1 \\
0.0380 & 1 \\
0.2980 & 2 \\
0.1050 & 2 \\
0.7260 & 3 \\
0.9535 & 2 \\
0.5889 & 4 \\
1.5000 & 3 \\
2.3605 & 4 \\
0.5000 & 1 \\
0.5000 & 1 \\
37.8536 & 4 \\
0.0009 & 1 \\
0.0500 & 1 \\
1.4459 & 2 \\
1.6368 & 4 \\
0.4437 & 1 \\
2.5668 & 3 \\
3.7853 & 1 \\
13.6074 & 6 \\
0.6078 & 2 \\
1.2096 & 1 \\
0.0793 & 1 \\
0.5000 & 1 \\
0.3844 & 1 \\
0.0089 & 5 \\
0.1000 & 1 \\
1.9462 & 1 \\
0.0010 & 1 \\
0.9903 & 1 \\
0.0009 & 1 \\
& \\
\hline
\end{tabular}


Plant: 3 Division:

Date Expiration:

A3060

A4 039

08581

08580

06213
05987

06502

95205

00623

96491

06575
00951

01113

00624

00322

0095

07250

00263

06690
92296

92296
07727

82726

04298

A4046

01894

00447

07688
$\mathrm{~A} 4035$

A6291

00707

01058

01058

02549

93928

87950

90355

A2237
89659

82659

89636

90647

* NISS

Department : Management Inventory Summary Report (by Building)

Room:

Area:

Installation: ORNL

WA Code:

\section{$000118-00-3$}

ass: HAZ Rating:

Cont Type Cd

3139-22-6 GUANOSINE 5'-DIPHOSPHATE SODIUM TYPE I

GUM TRAGACANTH

$N \mathrm{~N} \quad 0.0004$

$002363-71-5 \quad$ HENEICOSANOIC ACID

$000112-67-4$

HEXADECANOYL CHLORIDE

01608-26-0 HEXAMETHYLPHOSPHOROUS TRIAMIDE, TECH., 85\%

NISS

ALACK DRAWING INK 4415-4419

000495-69-2 HIPPURIC ACID

$010217-52-4$
$010034-93-2$ HYDRAZINE HYDRATE

$010034-93-2$

$000501-52-0$

HYDROCHLORIC ACID SOLUTIONS INCLUDING TECHNICAL GR HYDROCINNAMIC ACID

HYDROGEN

FLUORIDE-PYRIDINE

HYDROXYLAMINE-O-SULFONIC ACID

$002950-43-8$

$006303-21-5$

HYPOPHOSPHOROUS ACID

HYPOXANTHINE
HY0068-94-0

NISS
$000142-73-4$

NISS

IMINODIACETIC ACID

INLAND- 19
IODIC ACID

$007782-68-5$

IODIC ACI

IODINE MONOCHLORIDE

$007790-99-0$

$007439-89-6$

IODOFORM

006047-25-2 IRON(II) OXALATE DIHYDRATE

$000110-46-3$

$000079-30-1$

$000075-30-9$

ISOAMYL NITRIT

ISOBUTYRYL CHLORIDE

ISOPROPYL ALCOHOL

ISOPROP

J. PENNER CRT CLEAN SOLUTION

J.T. BAKER OXALIC ACID, 0 . IN VOLUMETRIC SOLUTION

JOHNSON BRAVO EXTRA HEAVY DUTY STRIPPER 04587

JOHNSON COMPLETE FOR FLOORS

JOHNSON CREW SHOWER ROOM CLEANER

JOHNSON LIQUID ENVY INSTANT CLEANER

JOHNSON MATTHEY TUNGSTEN AAS

JOHNSON SOET CARE LOTIONIZED SOAP

JOHNSON ULD BP 300 INSECTICIDE

JOHNSON WAX VIEH QUICK CLEANER

K\&W KNOCKER LOOSE

NISS

0.0000

0.0000

0.0999

0.0009

0.0250

0.0399

0.0099

12.0000

0.0296

0.099

0.3999

0.1133

13.8808

0.1999

6.6713
0.1000

1. 5000

0.0249

0.0152

2.4528
0.0009

3.7853

4.5000

5.7631
0.5000

1.0199

0.1000

3.1998

0.9535

0.299

0.0999

3.3259

0.5000

0.5000

19.0538

18.9269

38.6110

4.7317

4.7318

0.0999

18.9269

19.1162

19.1162
0.2561

indicates MSDS is not available
indicates MSDS updated within last three months 
Plant: 3 Division: Department: Control Area: Building: 3047 Room:

Area:

Date Expiration:

\begin{tabular}{|c|c|c|}
\hline $\begin{array}{l}82459 \\
A 8986 \\
89624 \\
12181 \\
94012 \\
96499 \\
00733 \\
04345 \\
A 3052 \\
B 3995 \\
94808 \\
83364 \\
08128 \\
05838 \\
96411 \\
06671 \\
07652 \\
06785 \\
04347 \\
06393 \\
08129 \\
96490 \\
08130 \\
07621 \\
07358 \\
07716 \\
07761 \\
07198 \\
07607 \\
07606 \\
96540 \\
05880 \\
05883 \\
04346 \\
08132 \\
00630 \\
00448 \\
04359 \\
00964 \\
08224 \\
06322 \\
00265 \\
00302 \\
06352 \\
04379 \\
07117 \\
00250 \\
08060 \\
00456 \\
01115\end{array}$ & $\begin{array}{l}\text { NISS } \\
\text { NISS } \\
\text { NISS } \\
038346-83-7 \\
\text { NISS } \\
000079-33-4 \\
001119-34-2 \\
000056-86-0 \\
018194-24-6 \\
\text { NISS } \\
\text { NISS } \\
\text { NISS } \\
000056-41-7 \\
009000-89-9 \\
007643-75-6 \\
000070-47-3 \\
000056-84-8 \\
000052-90-4 \\
000056-89-3 \\
000056-85-9 \\
007048-02-4 \\
000672-15-1 \\
000073-32-5 \\
000061-90-5 \\
000056-87-1 \\
000063-68-3 \\
001113-41-3 \\
000063-91-2 \\
000147-85-3 \\
000056-45-1 \\
005680-80-8 \\
000072-19-5 \\
000073-22-3 \\
000060-18-4 \\
000072-18-4 \\
000050-21-5 \\
010277-43-7 \\
001312-81-8 \\
000143-15-7 \\
015082-28-7 \\
000301-04-2 \\
007439-92-1 \\
010099-74-8 \\
001335-25-7 \\
000002-43-5 \\
006867-30-7 \\
016853-85-3 \\
019597-69-4 \\
0 * 00554-13-2 \\
007447-41-8\end{array}$ & 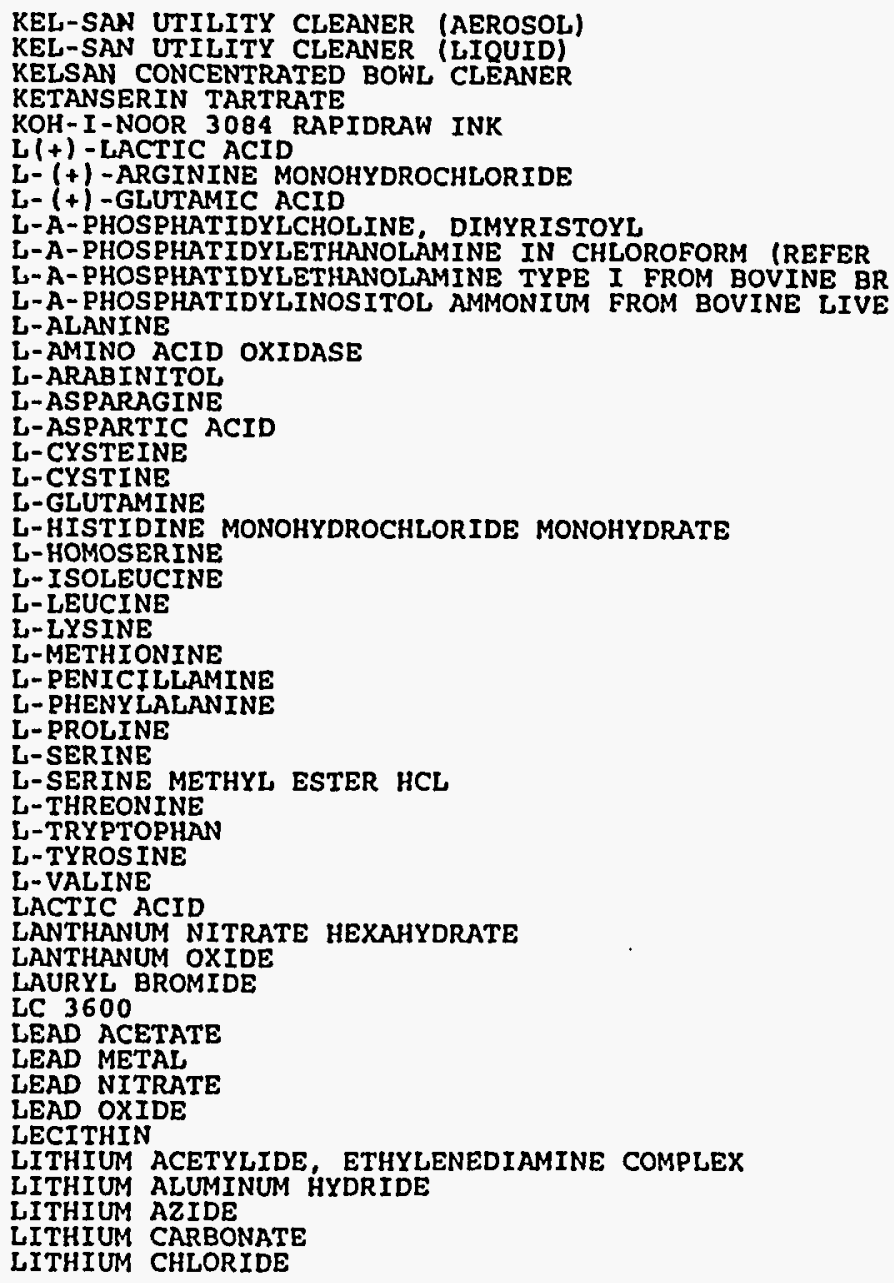 \\
\hline
\end{tabular}

\begin{tabular}{|c|c|}
\hline 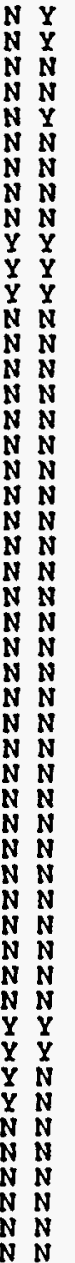 & $\begin{array}{r}1.4669 \\
10.2229 \\
11.7877 \\
0.0001 \\
0.5856 \\
0.0110 \\
0.0022 \\
0.2226 \\
0.0002 \\
0.0000 \\
0.0000 \\
0.0000 \\
0.0022 \\
0.0002 \\
0.0022 \\
0.0022 \\
0.0022 \\
0.0022 \\
0.0022 \\
0.0022 \\
0.0022 \\
0.0550 \\
0.0022 \\
0.0022 \\
0.0022 \\
0.0022 \\
0.0022 \\
0.0022 \\
0.0022 \\
0.2204 \\
0.1101 \\
0.0022 \\
0.0022 \\
0.0022 \\
0.0022 \\
1.1023 \\
1.0000 \\
1.1023 \\
0.2204 \\
0.2204 \\
2.3523 \\
1.1023 \\
1.0000 \\
1.1023 \\
0.0000 \\
0.2204 \\
0.0551 \\
0.0551 \\
7.3602 \\
13.2046\end{array}$ \\
\hline
\end{tabular}

$\begin{array}{lr}0.6654 & 1 \\ 4.6371 & 1 \\ 5.3468 & 1 \\ 0.0000 & 1 \\ 0.2652 & 12 \\ 0.0049 & 1 \\ 0.0010 & 1 \\ 0.1010 & 2 \\ 0.0000 & 1 \\ 0.0000 & 1 \\ 0.0000 & 1 \\ 0.0000 & 1 \\ 0.0010 & 1 \\ 0.0000 & 1 \\ 0.0009 & 1 \\ 0.0009 & 1 \\ 0.0009 & 1 \\ 0.0010 & 1 \\ 0.0010 & 1 \\ 0.0009 & 1 \\ 0.0010 & 1 \\ 0.0249 & 3 \\ 0.0010 & 1 \\ 0.0010 & 1 \\ 0.0010 & 1 \\ 0.0010 & 1 \\ 0.0009 & 1 \\ 0.0010 & 1 \\ 0.0010 & 1 \\ 0.0999 & 1 \\ 0.0499 & 3 \\ 0.0010 & 1 \\ 0.0010 & 1 \\ 0.0010 & 1 \\ 0.0010 & 1 \\ 0.5000 & 1 \\ 0.4535 & 1 \\ 0.5000 & 1 \\ 0.0999 & 1 \\ 0.0999 & 1 \\ 1.0668 & 3 \\ 0.5000 & 1 \\ 0.4535 & 1 \\ 0.5000 & 1 \\ 0.0000 & 1 \\ 0.0999 & 1 \\ 0.0249 & 1 \\ 0.0219 & 1 \\ 3.3385 & 5 \\ 5.9889 & 1 \\ & \end{array}$

WA Code:

Installation: ORNL

Ad: Temp cd: Cont Type Cd:

* indicates MSDS is not available 
Plant: 3 Division: Item ID

Date

Department :

control Area

Building: 3047

Room:

Area:
WA Code:

Rating:

Installation: ORN

Cont Type Cd:

\begin{tabular}{|c|c|c|}
\hline $\begin{array}{l}96501 \\
00457 \\
05745 \\
00461 \\
06333 \\
04392 \\
B 3479 \\
A 2682 \\
07800 \\
A 2686 \\
92963 \\
82376 \\
82986 \\
07316 \\
00465 \\
00466 \\
00467 \\
00468 \\
04133 \\
00469 \\
06579 \\
00632 \\
00633 \\
07738 \\
00227 \\
00470 \\
00471 \\
00473 \\
94734 \\
82978 \\
00270 \\
00300 \\
04446 \\
08296 \\
0443 \\
08227 \\
01968 \\
04464 \\
96504 \\
00318 \\
04467 \\
A 7241 \\
07669 \\
07787 \\
00055 \\
00197 \\
83605 \\
00037 \\
96508\end{array}$ & 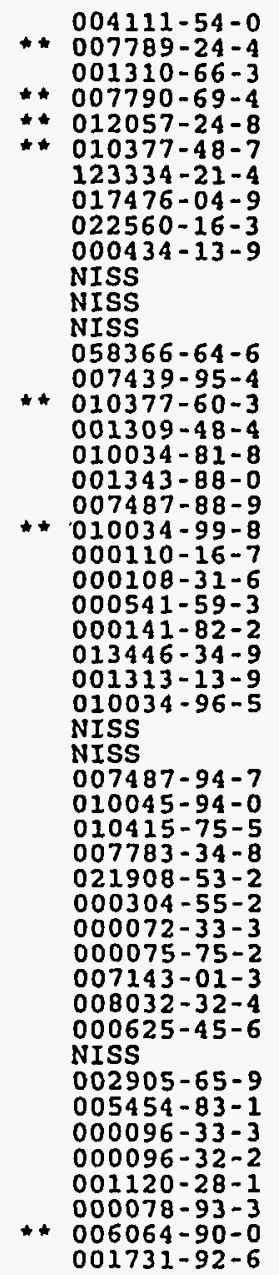 & 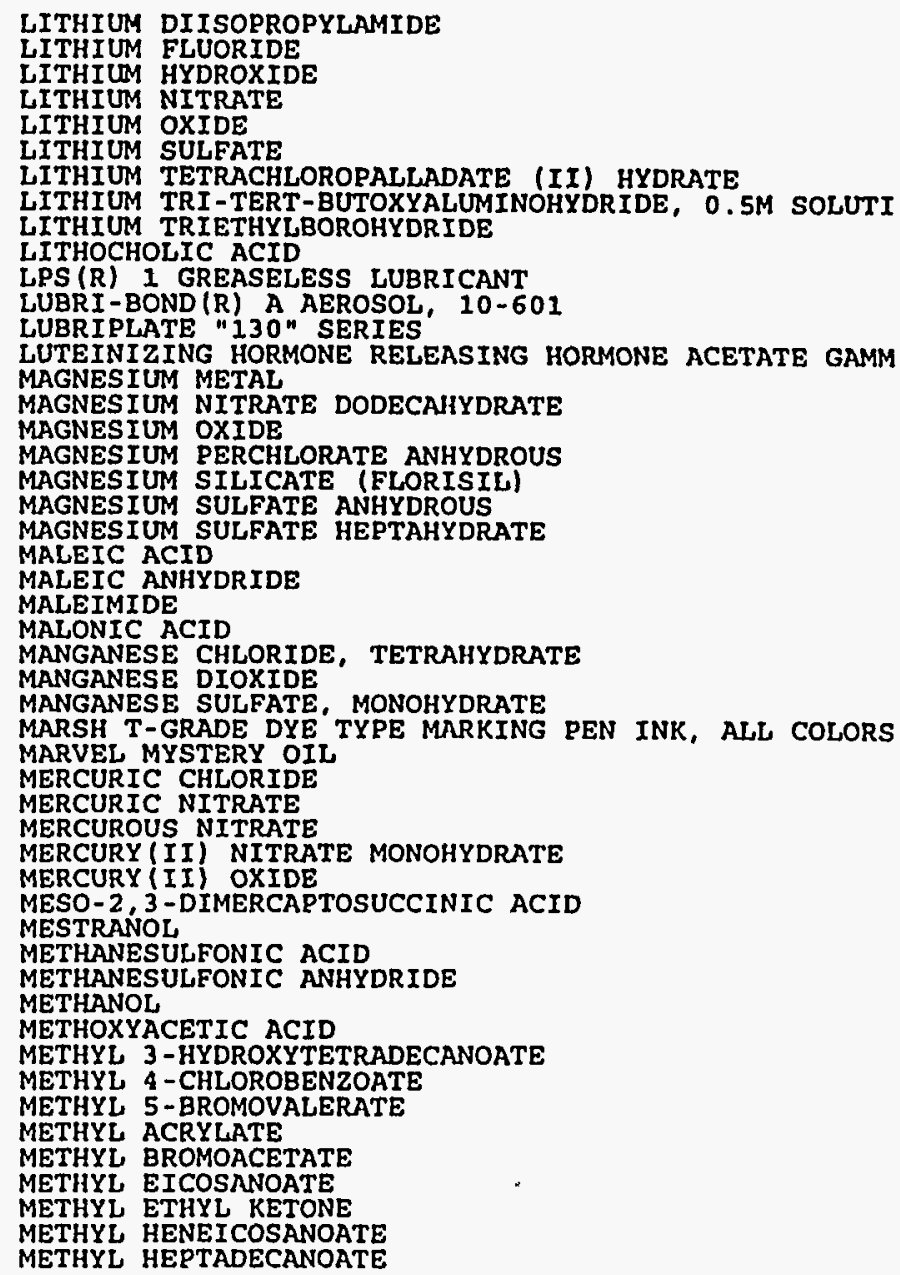 \\
\hline
\end{tabular}

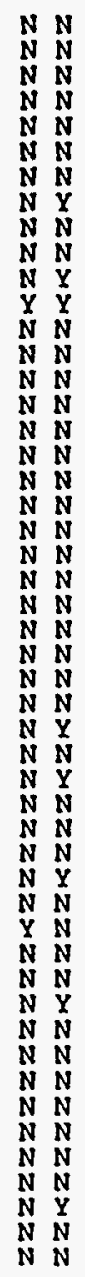

0.2204

* indicates MSDS is not available

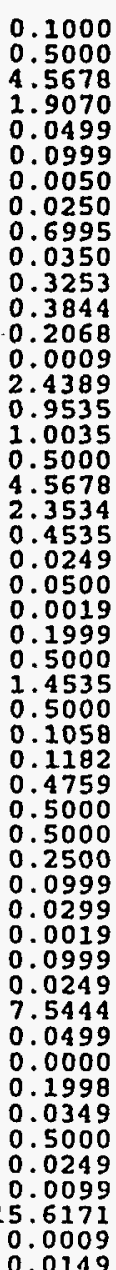

0.0149 
Plant: 3

3 Division:

Department : Building: 3047

Room:

WA Code:

Date Expiration:

Inv status: MSDS Avail: Maz Mat Grp Cd: ${ }^{\text {Ingredient: }}$ Phy State:

Area:

\begin{tabular}{|c|c|c|}
\hline $\begin{array}{l}04482 \\
00979 \\
B 3361 \\
04473 \\
B 4112 \\
04483 \\
04485 \\
04486 \\
01911 \\
00517 \\
04474 \\
04488 \\
00544 \\
04475 \\
A 9198 \\
B 4110 \\
A 9378 \\
A 7239 \\
07719 \\
00971 \\
07065 \\
00025 \\
05782 \\
07769 \\
01291 \\
06436 \\
04399 \\
91821 \\
00479 \\
04519 \\
00342 \\
00122 \\
06118 \\
A 5010 \\
00723 \\
07655 \\
04558 \\
00208 \\
00773 \\
00775 \\
00229 \\
96435 \\
96487 \\
00943 \\
00944 \\
00948 \\
00706 \\
00099 \\
05717 \\
00064\end{array}$ & 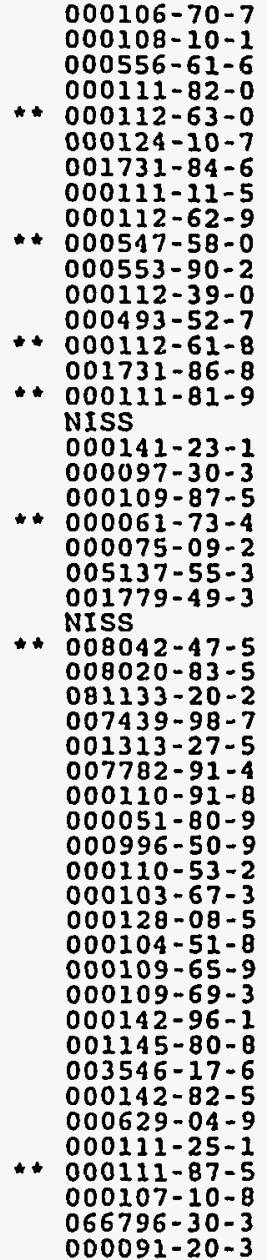 & 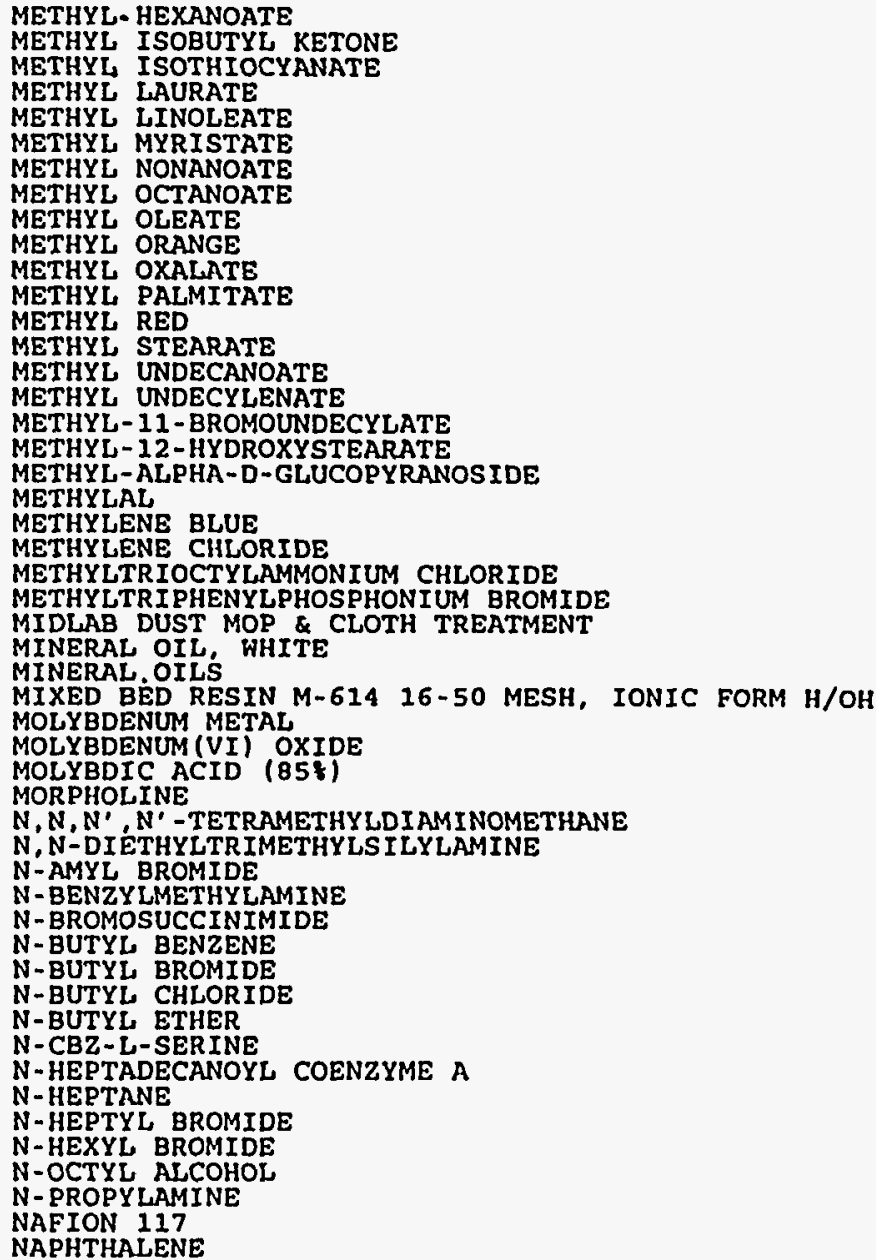 \\
\hline
\end{tabular}

$N$
$N$
$N$
$N$
$N$
$N$
$N$
$N$
$N$
$N$
$N$
$N$
$N$
$N$
$N$
$N$
$N$
$N$
$N$
$N$
$N$
$N$
$N$
$N$
$N$
$N$
$N$
$N$
$N$
$N$
$N$
$N$
$N$
$Y$
$N$
$N$
$N$
$N$
$N$
$N$
$N$
$N$
$N$
$N$
$N$
$N$
$N$
$N$
$N$
$N$
$N$
$N$
$N$
$N$
$N$
$N$
$N$
$N$
$N$
$N$
$N$
$N$
$N$
$N$
$N$
$N$
$N$
$N$
$N$
$N$
$N$
$N$
$N$
$N$
$N$
$N$
$N$
$N$
$N$

0.0390

Cont Type Cd:

* indicates MSDS is not available

\begin{tabular}{|c|}
\hline $\begin{array}{r}0.0390 \\
17.5420 \\
0.0110 \\
0.0191 \\
0.0195 \\
0.0220 \\
0.0193 \\
0.0193 \\
0.0192 \\
0.0551 \\
0.4408 \\
0.0220 \\
0.1540 \\
0.0220 \\
0.0192 \\
0.0196 \\
0.0220 \\
0.0022 \\
0.2204 \\
1.1023 \\
0.0440 \\
20.5468 \\
0.5511 \\
0.1102 \\
10.7445 \\
1627.3317 \\
9.4139 \\
2.1023 \\
1.4086 \\
0.2500 \\
2.6023 \\
1.1023 \\
0.0551 \\
0.0551 \\
0.2204 \\
0.2204 \\
0.2204 \\
0.0551 \\
0.0220 \\
1.1023 \\
2.2046 \\
0.2755 \\
0.0000 \\
2.2046 \\
0.4408 \\
0.1102 \\
1.3227 \\
0.0551 \\
0.0110 \\
0.5511\end{array}$ \\
\hline
\end{tabular}

$\begin{array}{ll}0.0176 & 2 \\ 7.9567 & 4 \\ 0.0050 & 1 \\ 0.0087 & 1 \\ 0.0088 & 1 \\ 0.0099 & 1 \\ 0.0087 & 1 \\ 0.0087 & 1 \\ 0.0087 & 1 \\ 0.0249 & 1 \\ 0.2000 & 2 \\ 0.0099 & 1 \\ 0.0698 & 6 \\ 0.0099 & 1 \\ 0.0087 & 1 \\ 0.0088 & 1 \\ 0.0100 & 1 \\ 0.0010 & 1 \\ 0.0999 & 1 \\ 0.5000 & 1 \\ 0.0198 & 2 \\ 9.3199 & 2 \\ 0.2499 & 1 \\ 0.0498 & 2 \\ 4.8735 & 5 \\ 38.1526 & 4 \\ 4.2700 & 3 \\ 0.9535 & 2 \\ 0.6389 & 4 \\ 0.1133 & 1 \\ 1.1901 & 1 \\ 0.5000 & 1 \\ 0.0249 & 1 \\ 0.0250 & 1 \\ 0.0999 & 1 \\ 0.1000 & 1 \\ 0.1000 & 1 \\ 0.0299 & 1 \\ 0.0099 & 1 \\ 0.5000 & 1 \\ 1.0000 & 1 \\ 0.1249 & 3 \\ 0.0000 & 1 \\ 1.0000 & 2 \\ 0.1999 & 2 \\ 0.0499 & 1 \\ 0.5999 & 2 \\ 0.0249 & 1 \\ 0.0050 & 1 \\ 0.2499 & 1 \\ & \end{array}$


Plant: 3 Division: Item ID:

Department

Bullding: 3047 Room: Area: Installation: ORNL

พิ Code:

\begin{tabular}{|c|c|c|}
\hline $\begin{array}{l}04605 \\
00321 \\
00485 \\
00641 \\
08279 \\
04619 \\
00275 \\
04624 \\
00648 \\
00054 \\
00644 \\
06164 \\
00144 \\
01133 \\
89735 \\
00595 \\
00210 \\
04682 \\
00705 \\
07682 \\
01093 \\
00669 \\
00093 \\
12631 \\
06629 \\
00795 \\
06233 \\
06511 \\
86793 \\
00111 \\
00387 \\
00388 \\
A 2397 \\
13059 \\
07765 \\
80206 \\
06500 \\
06795 \\
B 2593 \\
02081 \\
05801 \\
00649 \\
91402 \\
05373 \\
01046 \\
04903 \\
00288 \\
00493 \\
00494 \\
00495\end{array}$ & 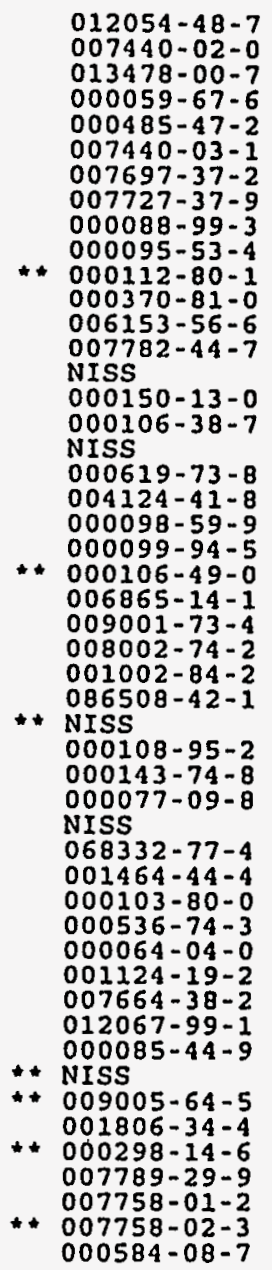 & 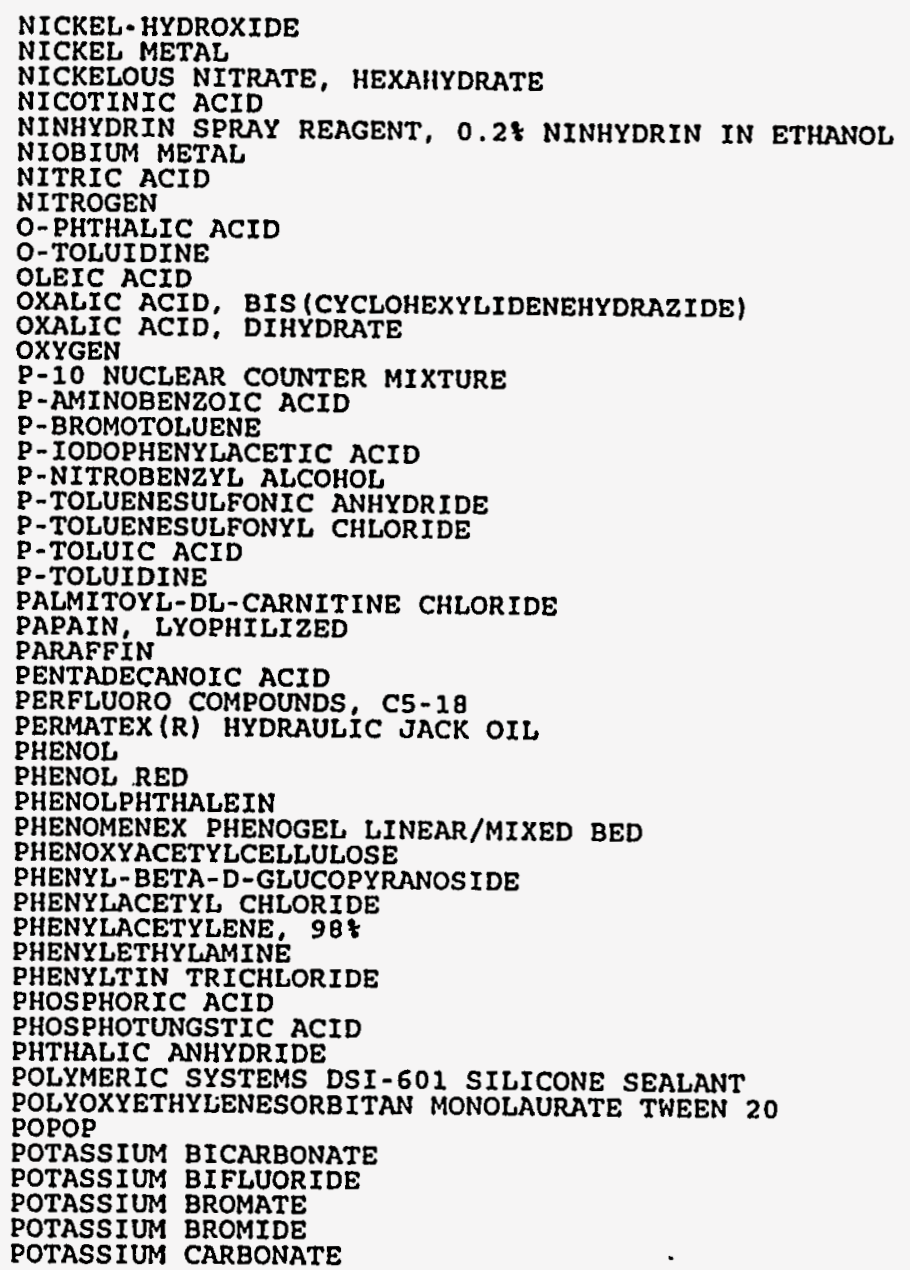 \\
\hline
\end{tabular}

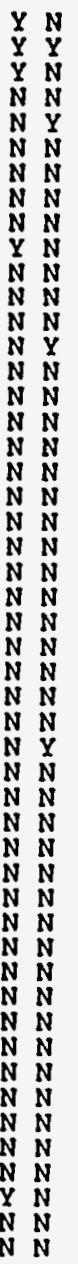

$Y$
$Y$
$Y$
$Y$
$N$
$N$
$N$
$N$
$N$
$N$
$N$
$N$
$N$
$N$
$Y$
$N$
$N$
$N$
$N$
$N$
$N$
$N$
$N$
$N$
$N$
$N$
$N$
$N$
$N$
$N$
$N$
$N$
$N$
$N$
$N$
$N$
$N$
$N$
$N$
$N$
$N$
$N$
$N$
$N$
$N$
$N$
$N$
$N$
$N$
$N$
$N$
$N$
$N$
$N$
$N$
$N$
$N$
$N$
$N$
$N$
$N$
$N$
$N$
$N$
$N$
$N$
$N$
$N$
$N$
$N$
$N$
$N$
$Y$
$N$
$N$
$N$
$N$
$N$

* indicates MSDS is not available

$\begin{array}{rr}0.5000 & \\ 2.3125 & 8 \\ 0.5000 & 1 \\ 0.0999 & 1 \\ 0.0249 & 1 \\ 0.0009 & 1 \\ 58.4940 & 17 \\ 23.4803 & 4 \\ 0.5000 & 2 \\ 0.0999 & 1 \\ 0.0999 & 1 \\ 0.0498 & 2 \\ 2.9999 & 2 \\ 13.7246 & 2 \\ 15.5245 & 5 \\ 0.1048 & 2 \\ 0.3999 & 4 \\ 0.0010 & 1 \\ 0.0749 & 2 \\ 0.0100 & 1 \\ 0.5998 & 3 \\ 0.5000 & 1 \\ 0.1998 & 2 \\ 0.0010 & 1 \\ 0.0039 & 1 \\ 0.4535 & 1 \\ 0.0250 & 1 \\ 63.5034 & 2 \\ 0.9463 & 1 \\ 0.4535 & 1 \\ 0.0018 & 2 \\ 0.3387 & 3 \\ 0.1000 & 1 \\ 0.0250 & 1 \\ 0.1000 & 1 \\ 0.1000 & 1 \\ 0.0750 & 3 \\ 0.0249 & 1 \\ 0.1000 & 1 \\ 5.7853 & 2 \\ 0.0999 & 1 \\ 0.0999 & 1 \\ 0.2379 & 3 \\ 0.0249 & 1 \\ 0.0099 & 2 \\ 0.9070 & 2 \\ 0.5000 & 1 \\ 0.5000 & 1 \\ 0.0500 & 2 \\ 6.9947 & 5 \\ & \end{array}$

1.1023
5.0987
1.1023
0.2204
0.0551
0.0022
128.9579
51.7551
1.1022
0.2204
0.2204
0.1102
6.6138
30.2575
34.2255
0.2314
0.8816
0.0022
0.1653
0.0220
1.3226
1.1023
0.4408
0.0022
0.0088
1.0000
0.0551
140.0000
2.0863
1.0000
0.0044
0.7473
0.2204
0.0551
0.2204
0.2204
0.1653
0.0551
0.2204
12.7544
0.2204
0.2204
0.5247
0.0551
0.0220
220000
1.1023
1.1023
0.1102
15.4207


Department:
LIST:

Control Area :

Building: 3047

Room:

Area:

WA Code:

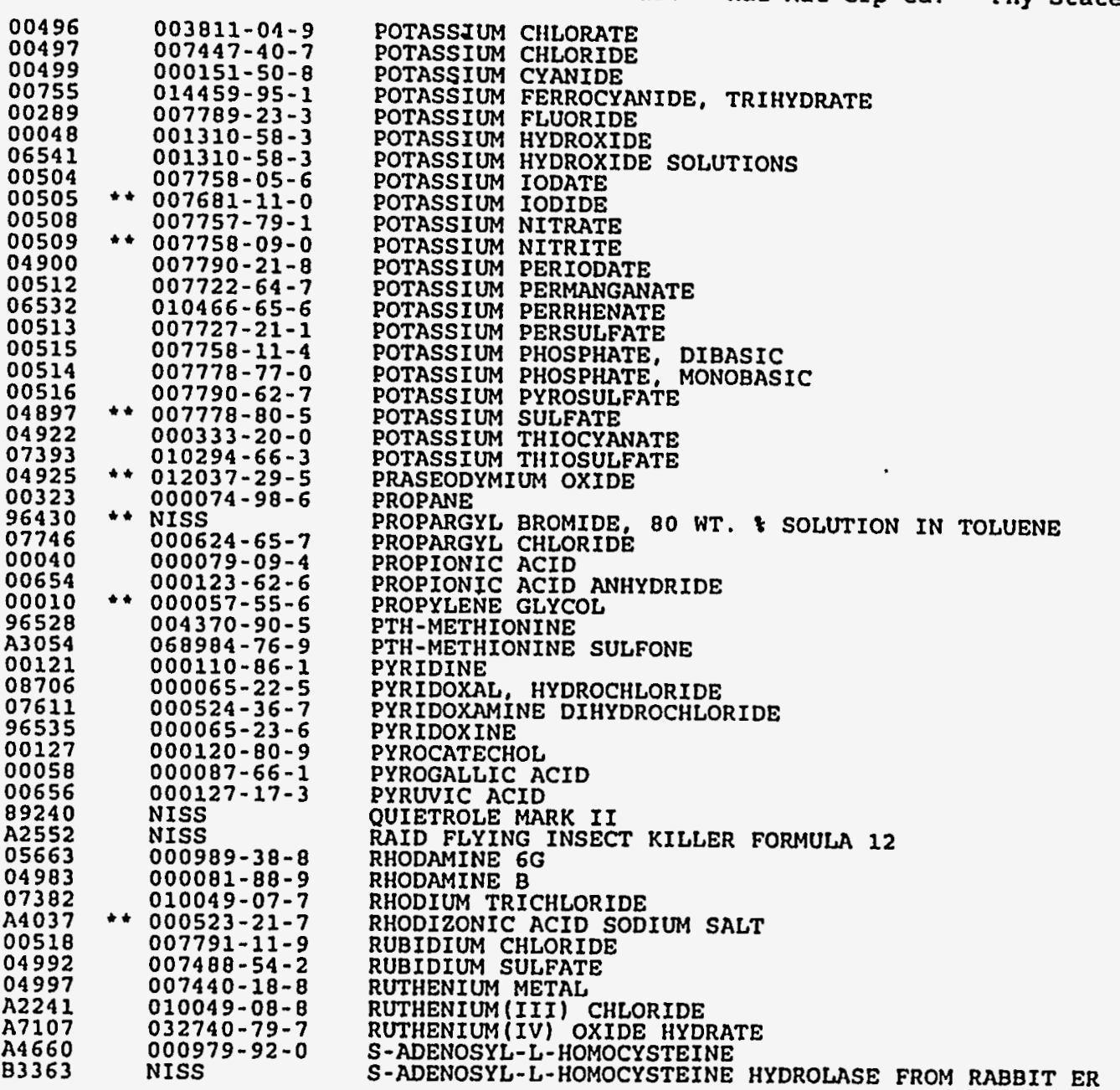

- indicates MSDS is not available

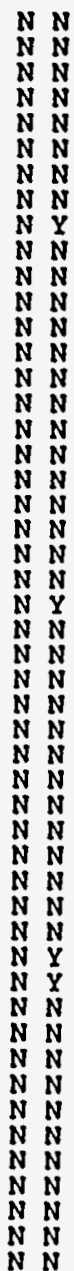

$N$
$N$
$N$
$N$
$N$
$N$
$N$
$N$
$N$
$N$
$N$
$N$
$N$
$N$
$N$
$N$
$N$
$N$
$N$
$N$
$N$
$N$
$N$
$N$
$N$
$N$
$N$
$N$
$N$
$N$
$N$
$N$
$N$
$N$
$N$
$N$
$N$
$N$
$N$
$N$
$N$
$N$
$N$
$N$
$N$
$N$
$N$
$N$
$N$
$N$
$N$
$N$
$N$
$N$
$N$
$N$
$N$
$N$
$N$
$N$
$N$
$N$
$N$
$N$
$N$
$N$
$N$
$N$
$N$
$N$
$N$
$N$
$N$
$N$
$N$
$N$
$N$
$N$
$N$
$N$
$N$
$N$
$N$
$N$
$N$
$N$
$N$
$N$
$N$
$N$

Cont Type Cd:

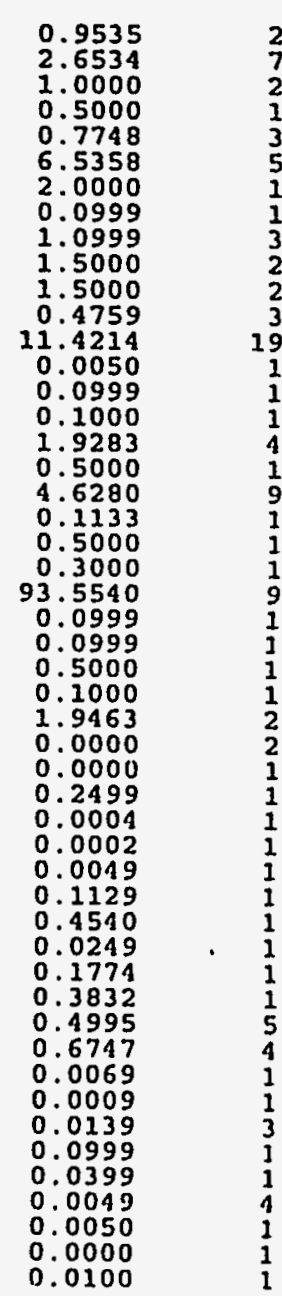


Plant: 3 Division:

Date Expiration:

\begin{tabular}{|c|c|}
\hline $\begin{array}{l}92251 \\
89646 \\
93167 \\
92144 \\
84036 \\
93539 \\
05042 \\
00280 \\
96536 \\
96537 \\
06487 \\
88509 \\
06924 \\
12547 \\
15390 \\
00446 \\
08477 \\
96414 \\
96402 \\
06044 \\
06047 \\
A 5908 \\
96511 \\
05276 \\
00809 \\
02117 \\
05786 \\
00348 \\
80533 \\
05067 \\
00235 \\
01399 \\
01403 \\
05064 \\
00521 \\
05706 \\
00522 \\
00018 \\
00525 \\
05096 \\
00527 \\
06592 \\
00531 \\
00532 \\
05760 \\
00292 \\
00534 \\
00536 \\
06385 \\
00537\end{array}$ & $\begin{array}{l}\text { NISS } \\
\text { NISS } \\
\text { NISS } \\
\text { NISS } \\
\text { * } 000057-63-6 \\
\text { NISS } \\
007446-08-4 \\
007782-49-2 \\
002897-21-4 \\
002578-28-1 \\
000630-10-4 \\
\text { NISS } \\
009048-71-9 \\
\text { NISS } \\
\text { NISS } \\
024346-00-7 \\
\text { NISS } \\
000280-64-8 \\
001730-25-2 \\
014044-65-6 \\
000109-72-8 \\
\text { NISS } \\
000917-54-4 \\
000125-20-2 \\
063231-67-4 \\
007631-86-9 \\
014808-60-7 \\
007699-41-4 \\
063148-58-3 \\
000563-63-3 \\
000534-16-7 \\
000506-64-9 \\
007440-22-4 \\
020667-12-3 \\
000127-09-3 \\
\text { 001 } \\
001344-00-9 \\
013011-54-6 \\
026628-22-8 \\
000144-55-8 \\
012232-99-4 \\
007631-90-5 \\
016940-66-2 \\
007789-38-0 \\
007647-15-6 \\
000125-65-2 \\
008006-28-8 \\
000497-19-8 \\
0007647-14-5 \\
007775-11-3 \\
000068-04-2\end{array}$ \\
\hline
\end{tabular}

Department :

Control Area

Building: 3047

Room:

Area:

WA Code:

\section{SANFORD ROLL-ON STAMP PAD INKER.}

SARGENT-WELCH DUO SEAL OIL

SBS BAR SOAP

SEE RECID 01917

SEE RECID 86878

SELENIUM DIOXIDE

SELENO-DL-CYST

SELENO-DL-METHIONINE

SELENOUREA

SEPHADEX

SHERWIN-WILLIAMS KRYLON (R) COLORWORKS (R) LACOUER S

SIGMA GUANOSINE $5^{\prime}$-TRIPHOSPHATE SODIUM TYPE III

SIGMA S-ADENOSYL-L-METHIONINE CHLORIDE

SIGMA URIDINE 5'-TRIPHOSPHATE SODIUM FROM YEAST TY

IIGMA-ALDRICH 9-BBN, 0.5M SOLUTION IN HEXANES

STA

S

SIGMA-ALDRICH CARDIOLIPIN FROM BOVINE HEART SODIUM

SIGMA-ALDRICH METHYLLITHIUM, 1.4M SOLUTION IN DIET

SIGMA-ALDRICH THXMOLPHTHALEIN $0.04 \%$ SOLUTION IN 50

SILICA, AMORPHOUS - OTHER FORMS

SILICA, CRYSTALLINE - QUARTZ

SILICONE RUBBERS

SILVER ACETATE

SILVER CARBONATE

SILVER CYANIDE

SILVR METAL

SODIUM ACETATE

SODIM ACETNOSILICATE

SODIUM AMMONIUM PHOSPHATE, TETRAHYDRATE

SODIUM AZIDE

SODIUM BICARBONATE

IUM BISMUTHATE

SODIUM BOROHYDR IDE

SODIUM BROMATE

SODIUM CACODYLATE

SODIUM CAICIUM HYDRATE

SODIUM CARBONATE

UM CHLORIDE

SODIUM CITRATE

* indicates MSDS is not available
indicates MSDS updated within last three months

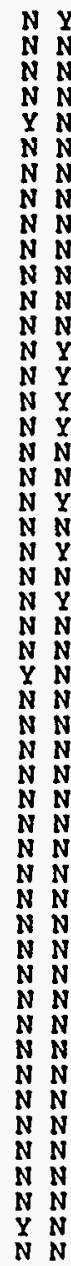

N $\begin{aligned} & N \\ & N \\ & N \\ & N \\ & N \\ & Y \\ & N \\ & N \\ & N \\ & N \\ & N \\ & N \\ & N \\ & N \\ & N \\ & N \\ & N \\ & N \\ & N \\ & N \\ & N \\ & N \\ & N \\ & N \\ & N \\ & N \\ & N \\ & N \\ & N \\ & N \\ & N \\ & N \\ & N \\ & N \\ & N \\ & N \\ & N \\ & N \\ & N \\ & N \\ & N \\ & N \\ & Y \\ & N \\ & N \\ & N \\ & N \\ & N \\ & N \\ & N \\ & N \\ & N \\ & N \\ & N \\ & N \\ & N \\ & N \\ & N \\ & N \\ & N \\ & N \\ & N \\ & N \\ & N \\ & N \\ & N \\ & N \\ & N \\ & N \\ & N \\ & N \\ & N \\ & N \\ & N \\ & N \\ & N \\ & N \\ & N \\ & N \\ & Y \\ & N \\ & N \\ & N \\ & N\end{aligned}$

Cont Type Cd

\begin{tabular}{|c|}
\hline $\begin{array}{l}0.1182 \\
9.7439 \\
2.0000 \\
8.5049 \\
0.0010 \\
0.5000 \\
0.1498 \\
0.5632 \\
0.0002 \\
0.0000 \\
0.0009 \\
0.1747 \\
0.1000 \\
0.3844 \\
0.0000 \\
0.0000 \\
0.0000 \\
0.1998 \\
0.0999 \\
1.6182 \\
0.1799 \\
0.0000 \\
0.0998 \\
0.0249 \\
15.4997 \\
0.4535 \\
1.5000 \\
2.0000 \\
0.1449 \\
0.0100 \\
0.0100 \\
0.0049 \\
0.0332 \\
0.1000 \\
3.7499 \\
0.5000 \\
0.5000 \\
0.5000 \\
1.0000 \\
0.2499 \\
2.5000 \\
0.1249 \\
1.0000 \\
0.0999 \\
0.2499 \\
1.0000 \\
2.3615 \\
1.5000 \\
0.9070 \\
0.5000\end{array}$ \\
\hline
\end{tabular}


Plant: 3 Division Item id

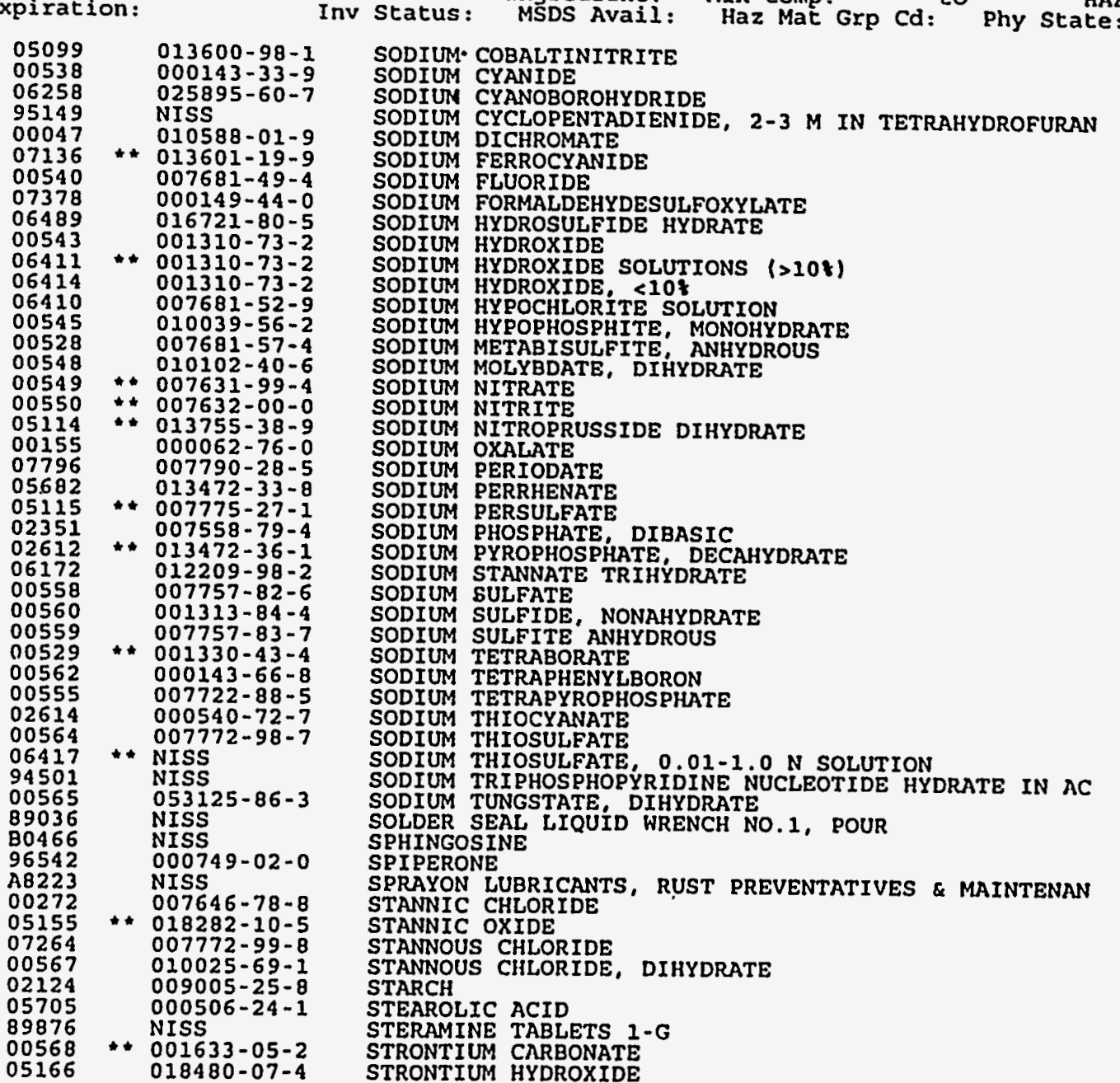

* indicates MSDS is not available
Control Area: Building: 3047 Room: Area:

Pressure HAZ Rating:

Page:
Installation: ORNL

WA Code:

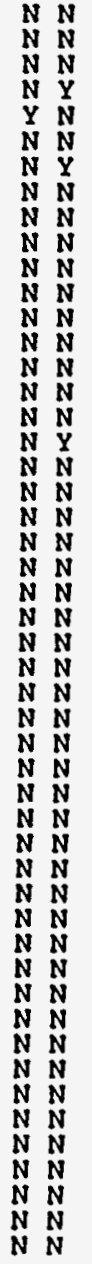

$N$
$N$
$N$
$N$
$N$
$Y$
$Y$
$N$
$N$
$N$
$N$
$N$
$N$
$N$
$N$
$N$
$N$
$N$
$N$
$N$
$N$
$N$
$N$
$N$
$N$
$N$
$N$
$N$
$N$
$N$
$N$
$N$
$N$
$N$
$N$
$N$
$N$
$N$
$N$
$N$
$N$
$N$
$N$
$N$
$N$
$N$
$N$
$N$
$N$
$N$
$N$
$N$
$N$
$N$
$N$
$N$
$N$
$N$
$N$
$N$
$N$
$N$
$N$
$N$
$N$
$N$
$N$
$N$
$N$
$N$
$N$
$N$
$N$
$N$
$N$
$N$
$N$
$N$
$N$

Cont Type Cd:

$\begin{array}{rr}2.0000 & 2 \\ 1.5000 & 3 \\ 0.2997 & 3 \\ 0.0002 & 1 \\ 0.5000 & 1 \\ 0.0099 & 1 \\ 0.5000 & 1 \\ 2.0000 & 1 \\ 0.0499 & 1 \\ 5.7679 & 3 \\ 3.8926 & 4 \\ 1.0000 & 1 \\ 20.8820 & 4 \\ 0.5000 & 1 \\ 0.2499 & 1 \\ 0.0999 & 1 \\ 0.0500 & 1 \\ 0.3999 & 1 \\ 0.1133 & 1 \\ 0.1133 & 1 \\ 0.0999 & 1 \\ 0.0010 & 1 \\ 0.5000 & 1 \\ 0.1129 & 1 \\ 0.5000 & 1 \\ 1.5000 & 3 \\ 14.6998 & 19 \\ 1.5000 & 2 \\ 1.4535 & 3 \\ 2.0000 & 2 \\ 0.0499 & 2 \\ 0.4535 & 1 \\ 0.4535 & 1 \\ 0.6999 & 2 \\ 1.6561 & 1 \\ 0.0000 & 1 \\ 0.5000 & 1 \\ 0.0295 & 1 \\ 0.0000 & 1 \\ 0.0050 & 5 \\ 0.3548 & 1 \\ 0.7034 & 2 \\ 0.4535 & 1 \\ 0.0250 & 1 \\ 1.0000 & 1 \\ 0.5000 & 1 \\ 0.0250 & 1 \\ 1.3608 & 1 \\ 1.4740 & 3 \\ 3.2679 & 2 \\ & \\ 0 & \\ 0\end{array}$


Plant: 3 Division: Item ID

Date Expiration:

Department :

Management Inven

Summary Report (by Building)

Control Area :

Building: 3047

Room:

$8:$ HÁz Rating:

Installation: 19

พA Code:

\begin{tabular}{|c|c|c|}
\hline $\begin{array}{l}00570 \\
01074 \\
00349 \\
A 9043 \\
00572 \\
02134 \\
00351 \\
94248 \\
00869 \\
96543 \\
00573 \\
06858 \\
87084 \\
05214 \\
A 3051 \\
96544 \\
96545 \\
02140 \\
07440 \\
A 0048 \\
00032 \\
84108 \\
05710 \\
A 0707 \\
A 7104 \\
A 2863 \\
01077 \\
A 4038 \\
07705 \\
08094 \\
A 2667 \\
00117 \\
07196 \\
05252 \\
96548 \\
82704 \\
07450 \\
B 3643 \\
01700 \\
01085 \\
A 4495 \\
06123 \\
00112 \\
00012 \\
05273 \\
06782 \\
06692 \\
00389 \\
00574 \\
02158\end{array}$ & $\begin{array}{l}\text { * } 010042-76-9 \\
000057-50-1 \\
005329-14-6 \\
034071-95-9 \\
007704-34-9 \\
007793-60-0 \\
007664-93-9 \\
\text { NISS } \\
014807-96-6 \\
012033-62-4 \\
001314-61-0 \\
007721-01-9 \\
\text { NISS } \\
000107-35-7 \\
006009-98-9 \\
000145-42-6 \\
001180-95-6 \\
013494-80-9 \\
010026-07-0 \\
\text { NISS } \\
000075-65-0 \\
* 001070-19-5 \\
000507-40-4 \\
000058-22-0 \\
087749-50-6 \\
032503-27-8 \\
002052-49-5 \\
000311-28-4 \\
098330-04-2 \\
000077-98-5 \\
002138-24-1 \\
000109-99-9 \\
000075-76-3 \\
000507-28-8 \\
002001-45-8 \\
\text { NISS } \\
02356-53-0 \\
034822-90-7 \\
001314-32-5 \\
00032-191-0 \\
000123-93-3 \\
000110-02-1 \\
000108-98-5 \\
000062-56-6 \\
* 012036-44-1 \\
000050-89-5 \\
000065-71-4 \\
000076-61-9 \\
* 007440-31-5 \\
013463-67-7\end{array}$ & 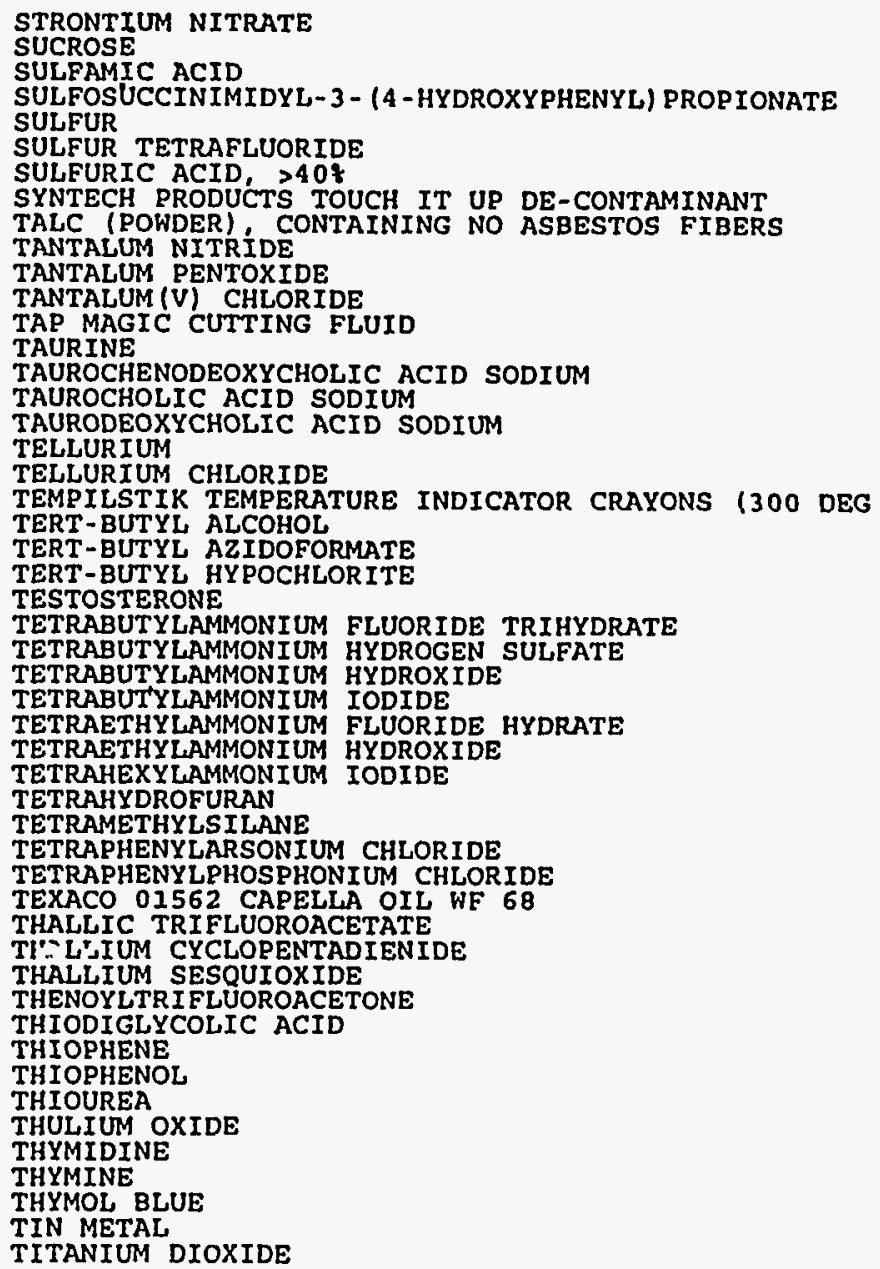 \\
\hline
\end{tabular}

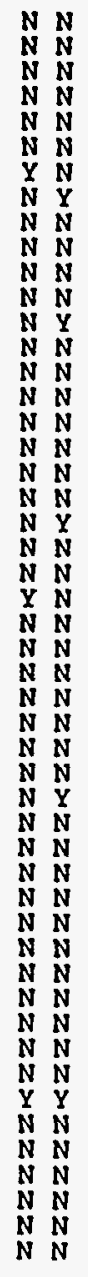

3.0951
7.7161
2.2046
0.0002
2.2046
2.0000
11.0228
0.1940
6.6138
0.0110
0.8011
2.2046
1.0431
0.0551
0.0002
0.0005
0.0022
3.9196
0.3857
1.2500
2.7557
0.0660
0.2204
0.1102
0.0440
0.0551
1.1023
0.0551
0.0551
1.1023
0.1102
2.1562
0.2204
1.1023
0.3086
8.3452
0.2204
0.0551
0.1102
1.6612
0.2204
1.1023
1.1023
2.2046
1.1023
0.0022
0.0220
0.0022
4.2046
7.2046

$\begin{array}{ll}1.4040 & 9 \\ 3.5000 & 4 \\ 1.0000 & 2 \\ 0.0000 & 1 \\ 1.0000 & 2 \\ 0.9070 & 2 \\ 4.9998 & 2 \\ 0.0079 & 1 \\ 3.0000 & 3 \\ 0.0049 & 1 \\ 0.3632 & 2 \\ 1.0000 & 2 \\ 0.4731 & 1 \\ 0.0249 & 1 \\ 0.0000 & 1 \\ 0.0002 & 1 \\ 0.0009 & 1 \\ 1.7780 & 9 \\ 0.1749 & 4 \\ 0.5669 & 1 \\ 1.2499 & 2 \\ 0.0300 & 3 \\ 0.0999 & 1 \\ 0.0499 & 2 \\ 0.0200 & 2 \\ 0.0250 & 1 \\ 0.5000 & 1 \\ 0.0249 & 1 \\ 0.0250 & 1 \\ 0.5000 & 1 \\ 0.0500 & 1 \\ 0.9779 & 3 \\ 0.0999 & 1 \\ 0.5000 & 1 \\ 0.1400 & 1 \\ 3.7853 & 1 \\ 0.0998 & 1 \\ 0.0250 & 2 \\ 0.0500 & 1 \\ 0.7534 & 1 \\ 0.0999 & 7 \\ 0.5000 & 1 \\ 0.5000 & 1 \\ 1.0000 & 2 \\ 0.5000 & 1 \\ 0.0010 & 1 \\ 0.0099 & 1 \\ 0.0009 & 1 \\ 1.90070 & 3 \\ 3.2675 & 6 \\ & \end{array}$

indicates MSDS is not available
indicates MSDS updated within last three months 
Plant:

Department : Control Area :

Building: 3047

Room:

Area:

WA Code:

Date Expiration:

Inv status: MSDS Avail: Maz Mat Grp Cd: ${ }^{\text {Io }}$ Phy State:

Pressure Cd: Temp Cd:

Cont Type Cd:

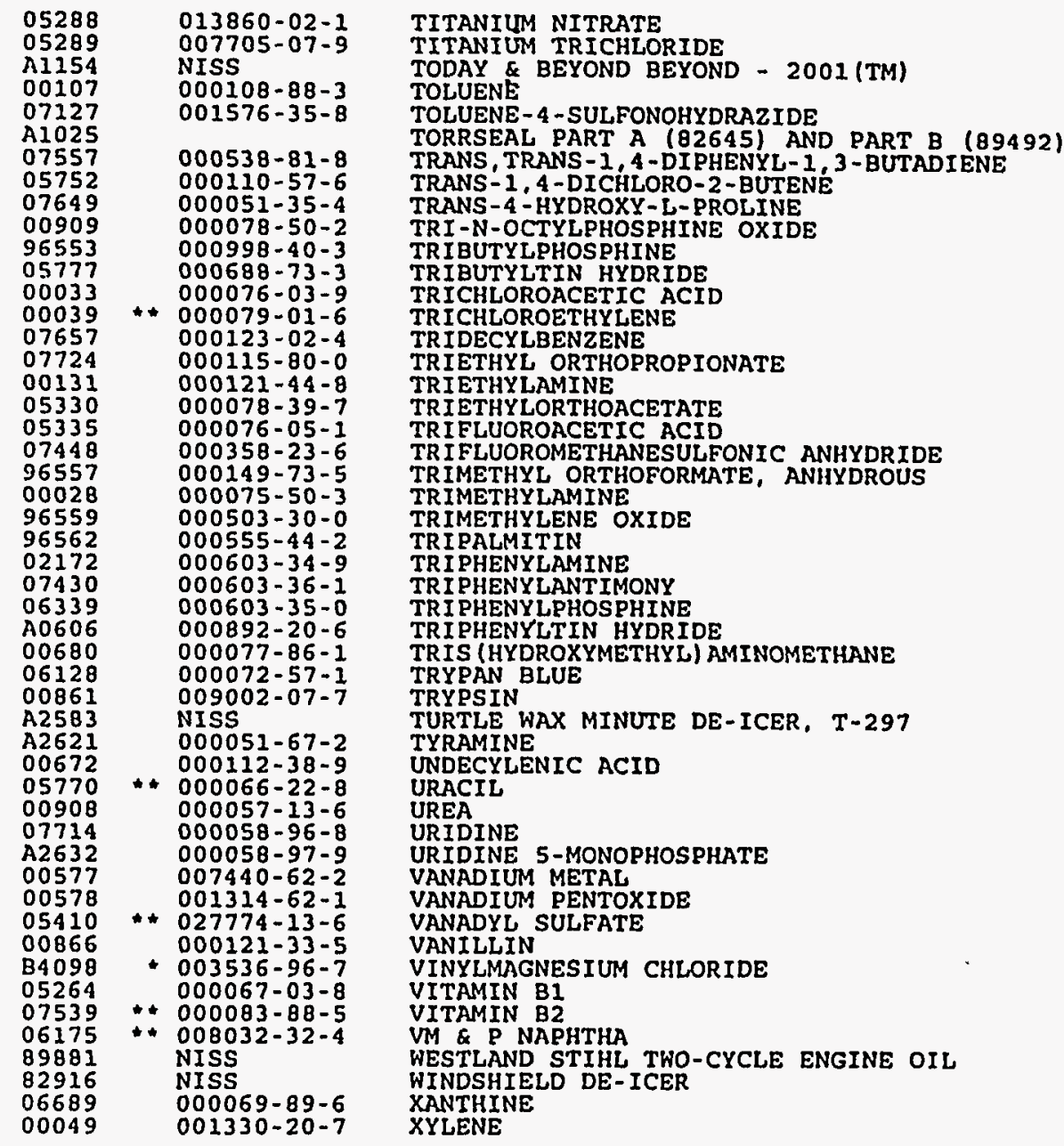

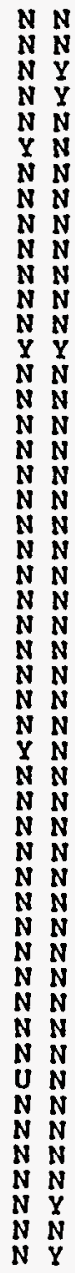

$\frac{1}{2} \cdot 1023$

2.1454
53.5764

24.8004
0.2204

0.3911

0.0551

0.0551
0.0022

0.0551

0.2204

1.0650
1.1023

12.2251

0.0551
0.4408

0.5511

0.4408
0.6612

0.0770

1.1023

1.1574

0.0551

0.0551

0.6612

0.0220
1.1023

0.2204

0.2204
10.3672

0.0551

0.2204
0.0110

14.9207

0.0002

0.0000

0.4408

1.1647
1.1022
0.2204

0.2204

0.0110

0.0110

8.8184

0.8345
1.4994

1.4994
0.0022

$\begin{array}{rr}0.5000 & 1 \\ 0.9731 & 2 \\ 24.3018 & 6 \\ 11.2493 & 3 \\ 0.0999 & 1 \\ 0.1774 & 1 \\ 0.0250 & 1 \\ 0.0249 & 1 \\ 0.0010 & 1 \\ 0.0249 & 1 \\ 0.0999 & 1 \\ 0.0298 & 2 \\ 0.5000 & 1 \\ 5.5452 & 1 \\ 0.0249 & 1 \\ 0.1998 & 2 \\ 0.2499 & 1 \\ 0.1999 & 2 \\ 0.2997 & 3 \\ 0.0346 & 4 \\ 0.5000 & 1 \\ 0.0999 & 1 \\ 0.5249 & 2 \\ 0.0049 & 1 \\ 0.0249 & 1 \\ 0.0249 & 1 \\ 0.2998 & 3 \\ 0.0100 & 1 \\ 0.5000 & 1 \\ 0.0999 & 1 \\ 0.0999 & 1 \\ 4.7017 & 11 \\ 0.0250 & 1 \\ 0.0999 & 1 \\ 0.0050 & 1 \\ 6.7675 & 10 \\ 0.0000 & 1 \\ 0.0000 & 1 \\ 0.1999 & 2 \\ 0.5282 & 3 \\ 0.4999 & 2 \\ 0.0999 & 1 \\ 0.0900 & 1 \\ 0.0049 & 1 \\ 0.0049 & 1 \\ 4.0000 & 1 \\ 0.3785 & 1 \\ 0.6802 & 2 \\ 0.0009 & 1 \\ 0.5000 & 1 \\ & \end{array}$

$\therefore$ indicates MSDS is not available 
Plant: 3 Division:

Item ID

Date Expiration

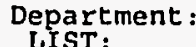

Department : Management Inventory Summary Report (by Building)

Control Area: Building: 3047

Room: Haz Mat Grp Cd: ${ }^{\text {To }}$ Phy State:

Area:

$\begin{array}{lll}96568 & 000087-99-0 & \text { XYLITOL } \\ 02188 & 007440-65-5 & \text { YTTRIUM METAL } \\ 00581 & 007646-85-7 & \text { ZINC CHLORIDE } \\ 00582 & 007440-66-6 & \text { ZINC METAL } \\ 00585 & 001314-13-2 & \text { ZINC OXIDE } \\ \text { A2484 } & 001315-09-0 & \text { ZINC SELENIDE } \\ 00586 & 00773-02-0 & \text { ZINC SULFATE } \\ 00587 & 014475-63-9 & \text { ZIRCONIUM HYDROXIDE } \\ 02679 & 010026-11-6 & \text { ZIRCONIUM TETRACHLORIDE }\end{array}$

Building 3047 Totals:

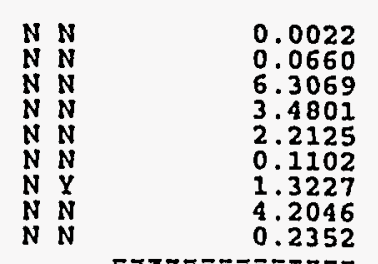

$=\pi==2=2 \pi z$
4923.1656
Page: 21
Installation: ORNL

Wก Code:

\section{Cont Type Cd:}

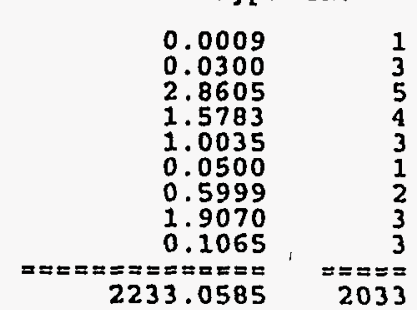

* indicates MSDS is not available

* indicates MSDS updated within last three months 
$14-1$

14. BUILDING 3517-FISSION PRODUCTS DEVELOPMENT LABORATORY 
ORNL FACILITY RmSE INFORMATION FORM

\begin{tabular}{|c|c|c|}
\hline \multicolumn{3}{|c|}{ General Information } \\
\hline $\begin{array}{l}\text { Area/Facility Name } \\
\text { (and aliases): }\end{array}$ & \multicolumn{2}{|c|}{$\begin{array}{l}\text { Building } 3517 \\
\text { Fission Products Development Laboratory (FPDL) }\end{array}$} \\
\hline \multicolumn{3}{|c|}{$\begin{array}{ll}\text { Organization responsible for area/facility } & \\
\text { (include specific person and phone number if possible): } & \text { R.E. Eversole (576-7483), } \\
& \text { IFDP Project Manager, } \\
& \text { ER Program, LMES }\end{array}$} \\
\hline Status (active/inactive): & Inactive, Standby Mode & Years of Operation: $\approx 30$ \\
\hline \multicolumn{3}{|c|}{$\begin{array}{l}\text { Activities involving the processing of radioactive source material have ceased in Building } 3517 \text {. Current } \\
\text { operations are limited to surveillance, maintenance, and deactivation activities and storage of most of } \\
\text { ORNL's inventory of }{ }^{90} \mathrm{Sr} \text { and }{ }^{137} \mathrm{Cs} \text {. Some over packing, packaging, and transfer/transport activities are also } \\
\text { planned for the facility for removal of remaining inventory and subsequent facility stabilization. Historical } \\
\text { operations included recovery of long-lived fission products from aqueous waste, purification and } \\
\text { pelletization of radiation source materials, and testing of new procedures for source fabrication. Large } \\
\text { quantities of }{ }^{137} \mathrm{Cs},{ }^{90} \mathrm{Sr},{ }^{144} \mathrm{Ce} \text {, and }{ }^{14} \mathrm{Pm} \text { have been processed from liquid, high-level waste streams each } \\
\text { year. Many Curies (Ci) of fission product materials have also been processed through the FPDL over the } \\
\text { years. Until } 1989 \text {, the FPDL processed }{ }^{90} \mathrm{Sr} \text { and }{ }^{137} \mathrm{Cs} \text { from Hanford, Washington for production of sources } \\
\text { for distribution through the Isotope Distribution Program. Radioisotope processing continued in the } \\
\text { manipulator cells between } 1975 \text { and } 1989 \text { at reduced levels of operation. This process equipment has been } \\
\text { placed in standby for possible utilization in the future. }\end{array}$} \\
\hline \multicolumn{3}{|c|}{$\begin{array}{l}\text { Physical description of arealfacility: } \\
\text { - Building } 3517 \text { was originally constructed in the late } 1950 \text { s. } \\
\text { The building is a two-story, concrete block structure containing operating areas, service areas, offices, } \\
\text { and personnel access areas. There is also an aluminum sided superstructure designated as the third story } \\
\text { which houses a } 20 \text {-ton crane, which services the operating cells. The building consists of approximately } \\
14,400 \text { sq. tt. of floor space. } \\
\text { - Building utilities include electric power, steam, and plant air. } \\
\text { The building is maintained as an active storage area for radioisotopes, although the processing hot cells } \\
\text { are in standby mode. } \\
\text { Building } 3517 \text { is located in an industrial area of ORNL to the southwest of Isotopes circle. The } \\
\text { immediate area surrounding the facility is paved for the most part with some grassy areas. } \\
\text { The operating area consists of nine process cells (cell } 1 \text { through } 9 \text { ), ten manipulator and service cells } \\
\text { (cell } 10 \text { through } 20 \text { - there is no longer a cell numbered } 19 \text { ), four tank farm cells (cell } 21 \text { through } 24 \text { ), } \\
\text { a ventilation filter pit, an old and a newly installed filtration housing, and several service/pipe tunnels. } \\
\text { (Some of the cells and one of the tunnels are presently inactive.) The four tank farm cells (listed as } \\
\text { numbered cells) and the two pipe tunnels are located underground adjacent to the northwest corner of } \\
\text { the building. } \\
\text { The FPDL includes two cell ventilation buildings, a new filter housing (no building number), and a } \\
\text { storage building. Building } 3547 \text { and } 3548 \text { are filtration facilities for the FPDL. Building } 3542 \text { is a } \\
\text { storage building for the facility, containing no radioactive materials. }\end{array}$} \\
\hline
\end{tabular}


Physical description of arealfacility: (Continued)

- An concrete pad exposed to the weather is located at the northeast corner of the facility and used for storage of casks containing radiologically contaminated material $\left({ }^{90} \mathrm{Sr}\right)$.

- Cell floor drains and the electropolisher glove box drain discharge to stainless steel collection tanks (S-223, S-324, and S-523) located in shielded underground cells adjacent to the northwest corner of the facility. Liquid waste is discharged from these tanks to the low-level, liquid waste (LLLW) system as necessary. Building floor and sink drains, steam condensate, and emergency cooling water for the storage well is monitored at Manhole 209 before discharge to the process waste system.

- Work with radioactive materials was performed primarily in the hot cells and electropolisher.

- Some interior portions of the building are restricted access areas due to radiologic contamination. Interior portions of the building observed were found to be in good condition. Many surfaces have been recently painted. Asbestos Containing Material (ACM), radiation (RAD) hazard areas, and polychlorinated bi-phenol (PCB) containing equipment are posted and/or labeled as appropriate.

- The building is operated in a "contained" state and kept under negative pressure relative to atmosphere.

- A building space diagram is attached to this form showing the locations of the various process areas and equipment.

\section{Release Information}

\section{Description of release, or threatened release, and source:}

Low levels of residual fixed and transferable radiologic surface contamination exist in areas of the facility as a result of historical operations. The contamination exists primarily in the hot cells and process equipment (vessels, hoods, piping, ventilation ducts, etc.). This contamination has accumulated from activities involving a variety of materials throughout the operating history of the facility and, therefore, cannot be attributed to a single release episode. The existing levels of RAD contamination in the facility are low and the presence of this contamination is not considered a significant hazard in its current state. The potential for release of additional radiologic contamination exists due to the large quantities of radioactive materials (primarily ${ }^{244} \mathrm{Cm},{ }^{90} \mathrm{Sr}$, and ${ }^{137} \mathrm{Cs}$ ) currently stored in the facility.

Hazardous materials (HAZMATs) (e.g., acids, hydraulic fluids, and other chemicals) were reportedly used, for the most part, in small quantities (i.e., less than 5 gallons or 100 pounds) during facility operations and currently for surveillance and maintenance (S\&M) activities. A few materials are currently used in quantities that exceed 100 pounds. According to available spill/release records and facility personnel interviews, no significant HAZMAT spills (i.e., spills having the potential to adversely affect human health and/or the environment) have been reported for this building. No current conditions were identified which present a potential for a significant HAZMAT release.

\section{Hazardous substances present:}

Hazardous substances remaining in Building 3517 consist mainly of residual RAD surface contamination $(\alpha, \beta, \gamma)$, radioactive materials in storage, PCBs, and quantities of miscellaneous HAZMATs. Areas of fixed and transferable RAD contamination are associated primarily with the hot cells and process equipment. PCBs are reportedly present in the form of forklift hydraulic fluid. Hazardous materials present in the building are listed on the attached HAZMAT inventory sheets. 


\section{Estimate (if possible) of quantities of hazardous substances that have been released and that could be} released:

The following represents the known quantities of substances currently existing in the facility. Radiologic surface contamination has accumulated from a legacy of many different programs and processes and cannot be attributed to a single release episode. It is only possible to quantify release amounts from contamination which currently exists in the facility and/or has been historically documented from past activities.

$90,000 \mathrm{Ci}^{90} \mathrm{Sr}$.

$350,000 \mathrm{Ci}^{137} \mathrm{Cs}$.

$\approx 3,500 \mathrm{Ci}{ }^{154} \mathrm{Eu}$.

$\approx 2,500 \mathrm{Ci}^{152} \mathrm{Eu}$.

$\approx 16,000 \mathrm{Ci}^{60} \mathrm{uCo}$.

$\approx 36,000 \mathrm{Ci}^{244} \mathrm{Cm}$.

Quantity of PCBs unknown (assumed to be less than 1 gallon).

$\approx 1,686$ pounds total miscellaneous HAZMATs (see attached HAZMAT inventory sheet).

(Quantity estimates obtained from Building 3517 Hazard Screening Report, ORNL PCB Hydraulic Equipment Inventory database, ORNL Hazardous Material Information System database.)

\section{Other pollutants or contaminants:}

Asbestos containing material, primarily in the form of thermal system insulation, has been confirmed present in this building. ACM observed is in fair to good condition and poses no immediate health threat. Based on the age of the facility, interior and exterior painted surfaces are assumed to be lead-containing. Verification samples are taken by ORNL Lead Management Program peršonnel on an "as-needed" basis to confirm the presence of lead in the paint (i.e., when work activities will disturb the paint, or paint is found to be deteriorating and poses a health or environmental threat). Interior painted surfaces observed are in good condition and pose no immediate health threat. Many of the interior surfaces have been recently painted which leaves the potential for lead-containing underlayers of paint. Paint on exterior surfaces was observed to be in good condition with no visible evidence of significant damage or deterioration.

\section{Groundwater}

Are there any suspected impacts to groundwater? If yes, please describe. Include any impacts to drinking water sources.

Building 3517 is located in Waste Area Grouping 1 at ORNL. Although no specific adverse spills or releases of hazardous substances threatening to groundwater were identified during this RmSE, it is suspected, based on available environmental studies conducted in WAG 1, that process and LLLW drains and associated piping may have leaked over the life of the facility. Buried process and LLLW piping and some drains have been found to be deteriorated and leaking in other facilities and areas of WAG 1. Studies have determined that groundwater in WAG 1 has been both radiologically and chemically contaminated. Numerous man-made radionuclides have been detected in WAG 1 groundwater samples including many of those processed in Building 3517. It is likely that liquid waste from activities involving radioisotopes in Building 3517 have historically contributed to WAG 1 groundwater contamination. However, the radionuclides detected in the groundwater were common to the processes and activities in many other buildings in the area which makes it difficult to determine exactly which building is, or was, the source of contamination.

Because of the reported small quantities of chemicals historically used in this facility, it is unlikely that such usage has significantly contributed to WAG 1 groundwater contamination. As part of the facility shutdown process, inactive process and LLLW drains within the building have reportedly been plugged to prevent further release. However, no documentation was available at the time of this report to verify which drains have actually been plugged and which have not. Information on drain locations and discharge points is available from the ORNL Engineering Support Office.

Other than the potential for historical impact to groundwater in WAG 1 via leaking process and LLLW lines external to the building, no existing immediate threat to groundwater was identified to be associated with this facility given its current status. 


\section{Surface Water}

Are there any suspected impacts to surface water? Ifyes, please describe. Also describe the most likely surface water migration route(s), if applicable. Include any impacts to drinking water sources.

WAG 1 is essentially bound by Fifth Creek to the east, White Oak Creek (WOC) to the south, and First Creek to the west. First and Fifth creeks flow south into (WOC) which flows to the west and exits WAG 1 at the southwest corner. Storm water (from surface runoff and storm water drainage system) and treated water from the process waste system discharges into WOC. The only potential for direct impact to surface water from Building 3517 in its current state would be from lead-containing paint chips which fall off the exterior painted surfaces and find their way into the storm water drainage system and eventually to WOC.

Surface water may have also been indirectly impacted by leaking process and LLLW lines external to the building. Some of these lines are known to have shared a common trench with storm water drainage piping. Contamination from leaking waste lines could potentially enter deteriorated storm water piping and migrate to WOC. The three creeks bordering WAG 1 are groundwater discharge points. Therefore, groundwater contaminated by leaking waste lines could also potentially impact surface water in the area.

Other than the potential for historical impact, no existing immediate threats to surface water were identified to be associated with facility.

\section{Air}

Are there any suspected impacts due to air emissions? If yes, please describe.

The Hazard Screening Report prepared for Building 3517 indicates that the potential for radiation exposure to personnel working inside and within the immediate vicinity of the facility as a result of potential airborne migration of radioactive particulates and physical contact with contaminated surfaces is considered insignificant. There is, however, a potential for significant radiation exposure as a result airborne migration of particulates from the remaining inventory of radioactive material should containment of this material be compromised. Areas of RAD contamination are identified, marked, and controlled as appropriate throughout the facility to protect against inadvertent exposure to personnel. Air flows from the interior of the building into the cells which exhaust through underground ducts to three stages of high efficiency particulate air (HEPA) filtration units and eventually to the stack 3039. Apart from catastrophic failure of the hot cells, storage equipment, or cell ventilation system, it is unlikely that radioactive air emissions from Building 3517 would impact personnel or the environment in its current state.

There is also a potential for impact to indoor air quality due to the presence of $\mathrm{ACM}$ and assumed lead-based paint (LBP) should these materials be disturbed. The ACM and assumed LBP remaining in the building are not considered to be immediate threats to indoor quality in their current state.

\section{Soil}

Are there any suspected impacts to soil? If yes, please describe.

As stated for groundwater, there is a potential for historical impact to soils in the area of Building 3517 due to leaking process and LLLW drain piping. Previous environmental studies have identified areas of soil contamination throughout WAG 1 and soil samples collected have detected radioisotopes common to the processes performed in this building. Since, these radioisotopes were common to the processes in many of the other buildings in the area, it is difficult to determine whether waste from Building 3517 has actually contributed to WAG 1 soil contamination based on the information reviewed during this RmSE.

There is also a potential for areas of soil adjacent to the facility to be impacted from lead if, in fact, exterior paint is found to be lead-containing. Deteriorating paint could dislodge from the surface and fall to the soil below. The exterior paint was observed to be good condition and does not pose an immediate threat in its current state.

It is unlikely that the quantities of chemicals that have been, and are being, used in Building 3517 have, or will, significantly impact(ed) soil in the surrounding area. 
Release Beyond Facility or Reservation Boundaries

Has or will the release migrate beyond the boundaries of the facility or reservation? If yes, please describe (including possible human or environmental receptors).

The following are considered potential scenarios where radiologic contamination could migrate beyond the facility or reservation boundaries:

- A person becomes inadvertently contaminated and leaves the facility/reservation undetected.

- Catastrophic failure of hot cells and/or contaminated equipment.

There is also a potential for assumed lead-containing paint which peels off of the building to be carried away with surface runoff during a rain event. Though these potentials exist, they are considered slight and unlikely due to the current status of the facility and the engineering/administrative controls that are in place to protect again such an event.

\section{Worker Safety}

Could the release pose a threat to workers? If yes, please describe.

Radiologically contaminated areas are isolated and well marked. Good radiation practices and standard operating procedures are enforced for worker safety. Personnel exiting the facility are required to "frisk" themselves to detect the presence of RAD contamination. Monitors and alarms are in place to detect any radioactive release within the building. $\mathrm{PCB}$ containing equipment and $\mathrm{ACM}$ are appropriately labeled. However, even with these safeguards in place, a potential threat to workers exists if safety measures are overlooked. This potential is not considered significant given the current status and level of activity of the building.

\section{Environmental Receptors}

Does the release pose a potential threat to environmental receptors? If yes, please describe. Include natural resources impacts.

No existing conditions posing an immediate significant threat to environmental receptors, including natural resources, were identified to be currently existing or associated with Building 3517.

\section{Mitigation}

What action(s) might be taken to abate'prevent release or impacts from release?

- Continued utilization and enforcement of engineering and administrative controls that are currently in place to protect workers and monitor conditions and activities in the building.

- Continue S\&M activities per Procedure IP-900. 
What actions are currently being taken to abate/prevent release or impacts from release?

Engineering and administrative controls are in place to control access to contaminated areas and to monitor conditions and activities within the facility for worker and environmental protection. Warning signs and labels are posted throughout the facility indicating $R A D, A C M$, and $P C B$ hazard areas. Standard operating procedures are in place for building access and surveillance and maintenance activities to protect against inadvertent contact and disturbance of contaminated areas and materials. Radiologically contaminated areas are monitored periodically by ORNL health physics personnel. Personnel are "frisked" upon exit of the facility to detect the presence of radiologic contamination. The building is currently in surveillance and maintenance status undergoing facility stabilization activities pursuant to acceptance into the Decontamination and Decommissioning (D\&D) Program. Inactive waste drains are reportedly plugged in contaminated areas to prevent inadvertent discharge of contamination beyond the facility. A groundwater monitoring program is in place to monitor contamination levels and migration in groundwater underlying WAG 1. The building is inspected for structural changes after each natural incident (earthquake, tornado, or other severe storm), fire and/or man induced activity which could cause cracking, failure, or deterioration of the facility and/or equipment that may allow contamination to be released. No such conditions have been reported for Building 3517.

Current actions being taken to prevent further release and ensure worker safety in Building 3517 are considered adequate until $\mathrm{D} \& \mathrm{D}$ activities begin.

\section{Other Environmental Authorities}

Is the release or threatened release potentially subject to other environmental statutory actions? If yes, please explain.

If paint is found to be lead-containing and samples fail the Toxicity Characteristic Leaching Procedure (TCLP) analysis, the building could qualify as a hazardous waste generator point under the Resource Conservation and Recovery Act (RCRA).

Maintenance Actions

Are maintenance actions necessary to eliminate potential threats to human health and the environment? If so, explain.

No potential hazards requiring maintenance actions were identified to be associated with Building 3517 .

\section{Removal Actions}

Are Removal Actions necessary to eliminate immediate threats to human health and the environment? If so, explain.

No imminent hazards requiring removal actions per $40 C F R 300.415$ were identified to be currently associated with Building 3517 . 


\section{Remedial Site Evaluation}

\section{Is a Remedial Site Evaluation needed?}

Areas of radiologic contamination associated with Building 3517 have been identified and marked as appropriate. However, it is suspected that process and LLLW drains and associated piping may have leaked beneath the slab of the building as a result of past practices. As a result, it is recommended that some type of remedial investigation be performed to assess the condition of the soil in this area before conducting any S\&M or D\&D activities which involve disturbing the slab.

ACM and PCB-containing equipment have also been identified, marked and documented. No further remedial investigation involving these hazards is considered necessary given the current status and future plans of this facility.

Based on the age of the facility, painted surfaces are assumed to contain lead. Samples of the paint should be taken and analyzed to verify the presence of lead prior to conducting any S\&M or D\&D activities which may disturb these assumed areas.

\section{No Further Investigation}

Is a finding of No Further Investigation appropriate? Please explain.

A finding of No Further Investigation implies that a facility or area is free from hazardous substances or contaminants that may threaten human health and the environment. Since Building 3517 contains substances and materials which may become threatening if not properly controlled, handled and managed during the S\&M cycle, a finding of No Further Investigation is inappropriate in this case.

\section{Additional Comments}

The following documents and databases were referenced for historical and hazard information related to Building 3517:

8 Phase I Safety Documentation, The Fission Product Development Laboratory, Building 3517, Hazard Screening, Document No. HS/3517/F/RT-29 (Rev. 0).

- Work Plan for the Isotopes Facilities Deactivation Project at Oak Ridge National Laboratory, Document No. ORNL/ER-249/R2.

- Building 3517 Occurrence Reports, 1989 to present.

- Site Characterization Summary Report for Waste Area Grouping 1 at Oak Ridge National Laboratory, Oak Ridge, Tennessee, Volumes 1 and 2, Document Nos. DOE/OR-1043/V1\&D1 and DOE/OR-1043/V2\&D1.

- ORNL Hazardous Material Information System Database.

- ORNL Drain System Survey Report for Building 3517.

The following personnel and offices were contacted and provided historical and current use/condition information for Building 3517:

- Mr. Karl Haff, Radiochemical Processing Department Head, ORNL Radiochemical Technology Section.

- Ms. Swati Wilson, Manager, ORNL Lead Management Program.

- Mr. Nathan Dunn, Hazardous Material Information System Office.

- Mr. Jade Thomas, ORNL Environmental Compliance Office.

- Mr. Joe Armento, ORNL Chemical Technology Division, Isotopes Facilities Shutdown Program. 
The RmSE of this facility was conducted for LMES under contract by:

Advanced Sciences, Inc.

800 Oak Ridge Turnpike, Suite C-102

Oak Ridge, TN

Todel R. Comant

Evaluator's Signature

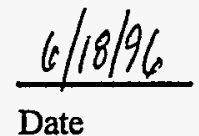


A Second Floor Building 3517 A-65
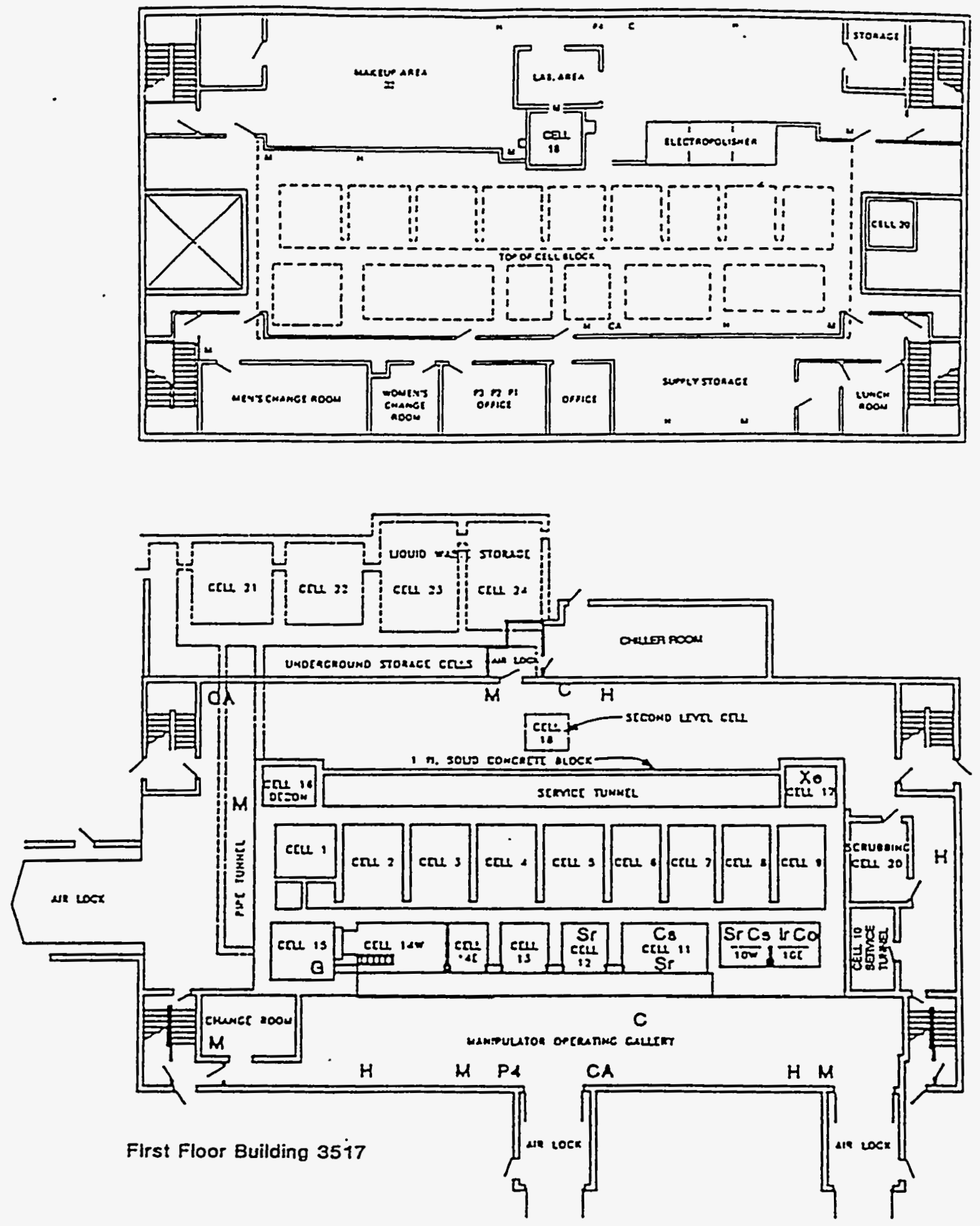

Fig. 18. Diagram of Building 3517. 
HAZARDOUS MATERIALS INFORMATTON SYSTEM Management Inventory Summary Report (by Building)

Plant: 3 Division

Date Expiration:

Department :

Building: 3517 Room:

Control Area

RoOm:

Ingredient: Mix Comp: $\mathrm{Haz}$ Mat Grp Cd:

Area:

UNCLASSIFIED

Page: 1

Installation: ORNL

WA Code:
Building: 3517

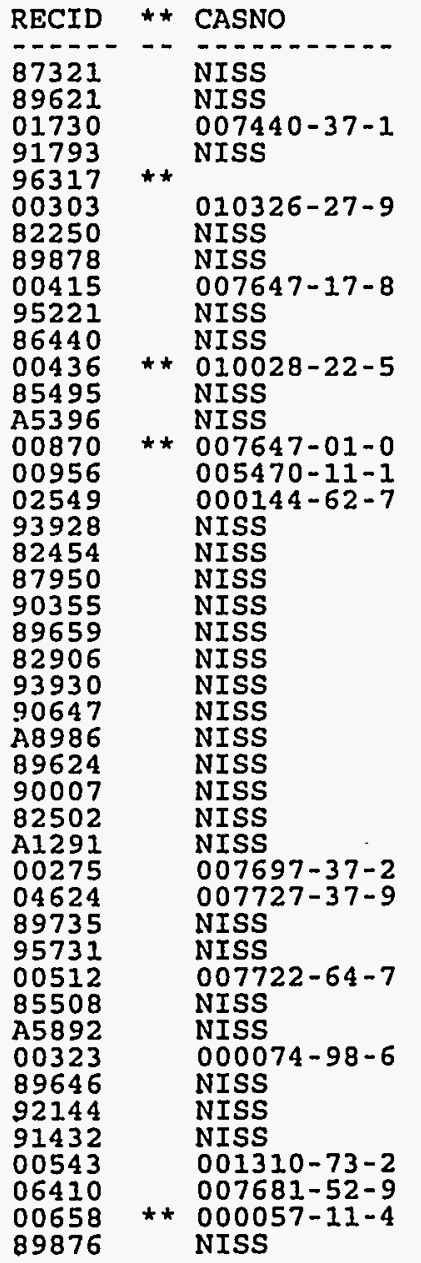

Material Name

AEROSOL TACOUER

AJAX ALL PURPOSE CLEANER (NON-PHOSPHATE)

ARGON

ARGON (95\%)/METHANE (5\%)

ASHLAND PLIOBOND 8003

BARIUM "CHLORIDE, DIHYDRATE

BIG "D" WATER SOL

CESIUM CHLORIDE

COLD KILL WASP/HORNET KILLER \#297852

CLEAR THIN SPREAD ADHESIVE

DURABOND SULFATE, ANHYDROUS

HIGH-PURITY NITROGEN AS NANO3

HYDROCHIOR IC ACTD

HYDROXYLAMINE HYDROCHLORIDE

J.T. BAKER OXALIC ACID, $0.1 \mathrm{~N}$ VOLUMETRIC SOLUTION

JOHNSON BRAVO EXTRA HEAVY DUTY STRIPPER 04587

JOHNSON COMPLETE FOR FLOORS

JOHNSON CREW SHOWER ROOM CLEANER

JOHNSON LIQUID ENVY INSTANT CLEANER

JOHNSON SNAPBACK LIQUID

JOHNSON SOFT CARE LOTIONIZED SOAP

JOHNSON WAX VIEW QUICK CLEANER

K\&W KNOCKER LOOSE

KEL-SAN UTILITY CLEANER (LIQUID)

KELSAN CONCENTRATED BOWL CLEANER

LUBRI - BOND A $(10-600)$

MIDLAB DUST MOP \& CLOTH TREATMENT

NITRIC ACID

ITROGEN

P-10 NUCLEAR COUNTER MIXTURE

PIANTSOT M

POTASSIUM PERMANGANATE

PPG CUSTOM BULK COLORANTS, 96 LINE

PREMIER CLEAN LUBE II

ROPANE

SANI-FRESH 10-10

SILICONE SPRAY LUBRICANT (AEROSOL) M9-14

SODIUM HYDROXIDE

STERAMINE TABLETS $1-G$ \begin{tabular}{ll} 
MMES \\
C \\
A \\
\hline & T \\
N & $Y$ \\
$N$ & $N$ \\
$N$ & $N$ \\
$N$ & $N$ \\
$N$ & $Y$ \\
$N$ & $N$ \\
$N$ & $N$ \\
$N$ & $N$ \\
$N$ & $N$ \\
$Y$ & $Y$ \\
$N$ & $Y$ \\
$N$ & $N$ \\
$N$ & $N$ \\
$N$ & $N$ \\
$N$ & $N$ \\
$N$ & $N$ \\
$N$ & $N$ \\
$N$ & $N$ \\
$N$ & $N$ \\
$N$ & $N$ \\
$N$ & $N$ \\
$N$ & $N$ \\
$N$ & $N$ \\
$N$ & $N$ \\
$N$ & $N$ \\
$N$ & $Y$ \\
$N$ & $N$ \\
$N$ & $Y$ \\
$N$ & $Y$ \\
$N$ & $Y$ \\
$N$ & $N$ \\
$N$ & $N$ \\
$N$ & $N$ \\
$N$ & $N$ \\
$N$ & $N$ \\
$N$ & $Y$ \\
$N$ & $N$ \\
$N$ & $N$ \\
$N$ & $N$ \\
$N$ & $N$ \\
$N$ & $Y$ \\
$N$ & $N$ \\
$N$ & $N$ \\
$N$ & $N$ \\
$N$ & $N$ \\
\end{tabular}

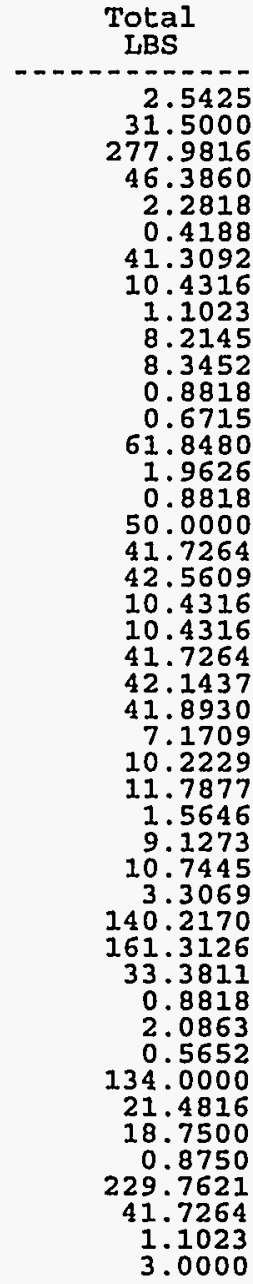

Total

- KILOGRAMS

4.1532

126.0909

21.0405

0.1900

18.7377

4.7317
0.5000

3. 5000

3.7853

0.4000

0.3046

.

0.8000

22.6798

18.9269

19.3055

4.7317

4.7317

18.9269

19.1162

19.0024

3.2527

4.6371

5.3468
0.7096

4.1398

4.8737

63.6020

73.1702

15.1415

0.4000

0.9463

0.2564

60.7816

9.7439

8.5049

0.3968

104.2193

18.9269

0.5000
1.3607
No of

tems

$--\frac{-}{3}$

$1 \frac{1}{3}$

2

* indicates MSDS is not available 
HMISR003C
$1 j: 44: 15$

Plant: 3 Division: Item ID

Date Expiration:

05685

80848

NISS

Department :

LIST:

Inv status: Management Inventory Summary Report (by Building)

Control Area :

Ingredient: Mix Comp: 3517

$\begin{array}{cc}3517 & \text { Room: } \\ \text { to } & \text { HAZ }\end{array}$ Phy state:

STRONTIUM FLUORIDE

TURCO DECON 4502

Building 3517

Totals :
UNCLASSIFIED Page:
Installation:

WA Code:

Area: ass: HAZ Rating:

Temp Cd: Cont Type Cd:

$\stackrel{N}{\mathrm{~N}} \underset{\mathrm{N}}{\mathrm{N}}$

0.4409
65.0000

$=======$

$\frac{1}{1}$

- indicates MSDS is not available

* * indicates MSDS updated within last three months 
, 
$15-1$

15. BUILDING 7025-TRITIUM TARGET FACILITY 

ORNL FACILITY RmSE INFORMATION FORM

\begin{tabular}{|c|c|}
\hline \multicolumn{2}{|c|}{ General Information } \\
\hline $\begin{array}{l}\text { Area/Facility Name } \\
\text { (and aliases): }\end{array}$ & \\
\hline \multicolumn{2}{|l|}{$\begin{array}{l}\text { Organization responsible for arealfacility } \\
\text { (include specific person and phone number if possible): }\end{array}$} \\
\hline Inactive, Standby Mode & Years of Operation: $\approx 20$ \\
\hline \multicolumn{2}{|c|}{$\begin{array}{l}\text { Description of Operation: } \\
\text { There are no current operations, other than surveillance, maintenance, and deactivation activities, on-going } \\
\text { in this building. Building } 7025 \text { was originally installed in support of tritium target needs for neutron } \\
\text { generation and special metallurgical studies. The building housed equipment for preparing tritium targets } \\
\text { made of titanium and diffusing of tritium into metallurgical samples. The metallurgical samples were } \\
\text { utilized for helium embrittlement studies. Other equipment, since removed, was necessary for preparation } \\
\text { of thin films of thorium oxide and/or uranium oxide. All tritium process activities within the Tritium Target } \\
\text { Facility were halted in October } 1989 \text {. All natural-thorium/natural-uranium operations ended in late } 1992 \text {. }\end{array}$} \\
\hline
\end{tabular}

Physical description of arealfacility:

- Building 7025 is a TVA surplus building which was installed at ORNL during the late 1960s.

- The facility is a single-story, prefabricated metal structure consisting of approximately $590 \mathrm{sq}$. ft. of floor space.

- This facility is remotely located in the East Support Area of ORNL and is basically isolated from other buildings in this area. The immediate area surrounding the facility is gravel and dirt with some grassy areas.

- Building 7025 is a small single-room laboratory which consisted of a tritium process hood and various related process equipment. The hot sink located at the east end of the tritium hood drained to a small underground collection tank adjacent to the east side of the facility. Wastewater from the lavatory sink was reportedly bottled for disposal away from the facility. There is no other drainage service available for this building.

- Building utilities include plant air and electrical service.

- Work with radioactive materials was performed primarily in the tritium hood and uranium evaporator.

- The exterior of the building was observed to be in fair to good condition with no visible areas of significant deterioration or damage.

- All tritium traps, cylinders, and sources of bulk material have been removed from the facility, as well as all thorium/uranium equipment. Basically, all equipment except for the tritium hood and ventilation equipment has been removed and the facility is being cleaned. The tritium hood is in the process of being decontaminated and dismantled.

- Generally, the interior of the building is in fair condition. Wall surfaces are deteriorating in areas as a result of the on-going removal work. Asbestos Containing Material (ACM) and radiation (RAD) hazard areas are posted and/or labeled as appropriate.

- A building space diagram is attached to this form showing the locations of the various process areas and equipment. 


\section{Release Information}

Description of release, or threatened release, and source:

Low levels of residual fixed and transferable radiologic surface contamination exist in areas of this facility as a result of historical operations. The contamination exists primarily in the tritium hood and associated process equipment. This contamination has accumulated from various activities throughout the operating history of the facility and, therefore, cannot be attributed to a single release episode. The existing levels of RAD contamination in the facility are low and well isolated or controlled. The presence of this contamination is not considered a significant hazard in its current state.

Hazardous materials (HAZMATs) (e.g., acids, hydraulic fluids, and other chemicals) were reportedly used in small quantities (i.e., less than 5 gallons or 100 pounds) during facility operations and currently for surveillance and maintenance (S\&M) activities. According to available spill/release records and facility personnel interviews, no significant HAZMAT spills (i.e., spills having the potential to adversely affect human health and/or the environment) have been reported for this building. No current conditions were identified which present a potential for a significant HAZMAT release.

\section{Hazardous substances present:}

Hazardous substances remaining in Building 7025 consist mainly of small amounts of residual fixed and transferable $\mathrm{RAD}$ surface contamination $(\alpha, \beta / \gamma)$. Areas of $\mathrm{RAD}$ contamination are associated primarily with the tritium hood and process equipment remaining in the building. These areas are marked and isolated and building access is restricted.

No polychlorinated bi-phenol (PCB) items were identified to be associated with this building.

Estimate (if possible) of quantities of hazardous substances that have been released and that could be released:

The following represents the known quantities of substances currently existing in the facility. Radiologic surface contamination has accumulated from a legacy of many different programs and processes and cannot be attributed to a single release episode. It is only possible to quantify release amounts from contamination which currently exists in the facility and/or has been historically documented from past activities.

$<2 \mu \mathrm{Ci} \alpha$

$<20 \mu \mathrm{Ci} \beta / \gamma$ as ${ }^{3} \mathrm{H}$

(Quantity estimates obtained from Building 7025 Hazard Screening Report)

\section{Other pollutants or contaminants:}

Asbestos containing material in the building has been identified, documented, and marked as appropriate. There is no immediate threat from the presence of ACM in this building. Based on the age of the facility, interior and exterior painted surfaces are assumed to be lead-containing. Verification samples are taken by ORNL Lead Management Program personnel on an "as-needed" basis to confirm the presence of lead in the paint (i.e., when work activities will disturb the paint, or paint is found to be deteriorating and poses a health or environmental threat). Interior painted surfaces observed are in fair condition with some localized areas of deterioration and pose no immediate health threat given the status of this facility. Paint on exterior surfaces was found to be in good condition, posing no immediate hazard to the surrounding area due to deterioration. 


\section{Groundwater}

Are there any suspected impacts to groundwater? If yes, please describe. Include any impacts to drinking water sources.

Building 7025 is located in a fairly remote area of ORNL, approximately 1.5 miles east of Isotopes Circle. The building is not serviced by a common drainage system. A small local underground collection tank adjacent to the east side of the building was used to collect liquid waste from the hot sink in the tritium hood. Reportedly, no liquid waste streams were generated by the processes in this building, and this sink was only used by personnel for washing and decontamination. Although it was not confirmed, it is assumed that wastewater from the water fountain in the building also drained to this tank. Wastewater from the lavatory sink was reportedly bottled and disposed of away from the facility. The integrity of the existing collection tank is unknown. Reportedly, the contents have been pumped out and it currently sits empty. However, no information was identified during this RmSE to indicate the size of this tank, its historical content, or to confirm or deny whether the tank may have leaked. Due to the lack of information concerning this tank, there is a potential, which is common to all tanks of this age, that they may have leaked in the past. If the tank has leaked and did contain hazardous substances there is a high potential that groundwater in the immediate area may have been impacted. However, this potential could not be substantiated based on information identified during this RmSE.

Aside from the historical potential for groundwater impact, no existing immediate threat to groundwater was identified to be associated with this building.

\section{Surface Water}

Are there any suspected impacts to surface water? If yes, please describe. Also describe the most likely surface water migration route(s), if applicable. Include any impacts to drinking water sources.

The only potential threat to surface water identified during this $\mathrm{RmSE}$ is related to exterior painted surfaces if, in fact, the paint does contain lead. The potential exists for surface water to be impacted from deteriorated paint which washes of the building and finds its way to surface water with the storm water runoff.

Other than the potential for lead-based paint (LBP) impact, no existing immediate threat to surface water was identified to be associated with this building.

\section{Air}

Are there any suspected impacts due to air emissions? If yes, please describe.

The Hazard Screening Report prepared for Building 7025 indicates that there is a slight potential for radiation exposure to personnel working in or around the facility due to potential airborne migration of radioactive particulates and physical contact with contaminated surfaces. Because of the low levels and nature of $\mathrm{RAD}$ contamination within this facility, potential impacts to persons or the environment surrounding the facility are considered insignificant. Areas of RAD contamination are identified, marked, and controlled as appropriate throughout the facility to protect against inadvertent exposure to personnel. Air within the building is controlled by a local exhaust system. Exhaust air from the now-removed uranium evaporator was filtered through a high efficiency particulate air (HEPA) filter inside the building before being discharged to atmosphere. No HEPA filtration was used in the tritium hood exhaust since the processes in the hood involved only radioactive gases.

Are there any suspected impacts due to air emissions? If yes, please describe. (Continued)

Apart from catastrophic failure of the structure which could disturb existing contaminated surfaces, it is unlikely that radioactive air emissions from this building would impact personnel or the environment.

There is also a potential for impact to indoor air quality due to the presence of ACM and assumed LBP should these materials be disturbed. These hazards are not considered to be an immediate threat to indoor air quality given the current status of this facility. 


\section{Soil}

Are there any suspected impacts to soil? If yes, please describe.

As stated for groundwater, there is a potential for historical impact to soils in the area of Buildings 7025 if, in fact, the collection tank adjacent to the building has leaked. No evidence of soil contamination such as staining, stressed vegetation, odor, etc. were observed in the area of the UST. This potential for soil contamination could not be substantiated based on information identified during this RmSE.

There is also a potential for areas of soil adjacent to the facility to be impacted from lead if, in fact, exterior paint is found to be lead-containing. Deteriorating paint could dislodge from the surface and fall to the soil below. The exterior paint was observed to be good condition and does not pose an immediate threat in its current state.

\section{Release Beyond Facility or Reservation Boundaries}

Has or will the release migrate beyond the boundaries of the facility or reservation? If yes, please describe (including possible human or environmental receptors).

The following are considered potential scenarios where radiologic contamination could migrate beyond the facility or reservation boundaries:

- A person becomes inadvertently contaminated and leaves the facility/reservation undetected.

- Catastrophic failure of the structure and/or contaminated equipment.

There is also a potential for assumed lead-containing paint which peels off exterior surfaces of the buildings to be carried away with surface runoff during a rain event. Though these potentials exist, they are considered slight and unlikely due to the current status of the facility and the engineering/administrative controls that are in place to protect again such an event.

\section{Worker Safety}

\section{Could the release pose a threat to workers? If yes, please describe.}

Radiologically contaminated areas are isolated and well marked. Good radiation practices and standard operating procedures are enforced for worker safety. Personnel exiting the facility are required to "frisk" themselves to detect the presence of $\mathrm{RAD}$ contamination. However, even with these safeguards in place, a potential threat to workers exists if safety measures are overlooked. This potential is not considered significant given the current status and level of activity of building.

\section{Environmental Receptors}

Does the release pose a potential threat to environmental receptors? If yes, please describe. Include natural resources impacts.

No existing conditions posing an immediate significant threat to environmental receptors, including natural resources, were identified to be currently existing or associated with Building 7025.

\section{Mitigation}

What action(s) might be taken to abate/prevent release or impacts from release?

- Continued utilization and enforcement of engineering and administrative controls that are currently in place to protect workers and monitor conditions and activities in these buildings.

- Continue S\&M activities per Procedure IP-900. 
What actions are currently being taken to abate/prevent release or impacts from release?

Engineering and administrative controls are in place to control access to contaminated areas and to monitor conditions and activities within the facilities for worker and environmental protection. Warning signs and labels are posted throughout the facilities indicating RAD hazard areas. Standard operating procedures are in place for building access and surveillance and maintenance activities to protect against inadvertent contact and disturbance of contaminated areas and materials. Radiologically contaminated areas are monitored periodically by ORNL health physics personnel. Personnel are "frisked" upon exit of the facility to detect the presence of radiologic contamination. The building is currently in surveillance and maintenance status awaiting entry into the Decontamination and Decommissioning (D\&D) Program. The building is inspected for structural changes after each natural incident (earthquake, tornado, or other severe storm), fire and/or man induced activity which could cause cracking, failure, or deterioration of the facility and/or equipment that may allow contamination to be released. No such conditions have been reported for Building 7025 . The building remains locked and secured to limit access.

Current actions being taken to prevent further release and ensure worker safety in Building 7025 are considered adequate until D\&D activities begin.

\section{Other Environmental Authorities}

Is the release or threatened release potentially subject to other environmental statutory actions? If yes, please explain.

If paint is found to be lead-containing and samples fail the Toxicity Characteristic Leaching Procedure (TCLP) analysis, the building could qualify as a hazardous waste generator point under the Resource Conservation and Recovery Act (RCRA).

\section{Maintenance Actions}

Are maintenance actions necessary to eliminate potential threats to human health and the environment? If so, explain.

No existing potential hazards requiring maintenance actions were identified to be associated with Building 7025.

Removal Actions

Are Removal Actions necessary to eliminate immediate threats to human health and the environment? If so, explain.

No imminent hazards requiring removal actions per 40 CFR 300.415 were identified to be currently associated with Building 7025 .

\section{Remedial Site Evaluation}

\section{Is a Remedial Site Evaluation needed?}

It is recommended that a Remedial Site Evaluation (RSE) be conducted at Building 7025 to determine whether the collection tank located adjacent to the building has leaked and whether a remedial investigation is necessary.

Building 7025 has reportedly been surveyed for asbestos containing material (ACM); therefore, no further remedial investigation involving this hazard is considered necessary given the current status and future plans of this facility.

Based on the age of the facility, painted surfaces are assumed to contain lead. Samples of the paint should be taken and analyzed to verify the presence of lead prior to conducting any S\&M or D\&D activities which may disturb these assumed areas. 
No Further Investigation

Is a finding of No Further Investigation appropriate? Please explain.

A finding of No Further Investigation implies that a facility or area is free from hazardous substances or contaminants that may threaten human health and the environment. Since Building 7025 contains substances and materials which may become threatening if not properly controlled, handled and managed during the S\&M cycle, a finding of No Further Investigation is inappropriate in this case.

\section{Additional Comments}

The following documents and databases were referenced for historical and hazard information related to Building 7025:

- Phase I Safety Documentation, Tritium Target Facility, Building 7025, Hazard Screening, Document No. HS/7025/3093/F/RT-33 (Rev. 0).

- Work Plan for the Isotopes Facilities Deactivation Project at Oak Ridge National Laboratory, Document No. ORNL/ER-249/R2.

- Building 7025 Occurrence Reports, 1989 to present.

- ORNL Hazardous Material Information System Database.

The following personnel and offices were contacted and provided historical and current use/condition information for Building 7025:

- Mr. Karl Haff, Radiochemical Processing Department Head, ORNL Radiochemical Technology Section.

- Mr. Herman Phillips, Assistant Facilities Manager, ORNL Special Projects.

- Ms. Swati Wilson, Manager, ORNL Lead Management Program.

- Mr. Nathan Dunn, Hazardous Material Information System Office.

- Mr. Jade Thomas, ORNL Environmental Compliance Office.

- Mr. Joe Armento, ORNL Chemical Technology Division, Isotopes Facilities Shutdown Program.

The RmSE of this facility was conducted for LMES under contract by:

Advanced Sciences, Inc.

800 Oak Ridge Turnpike, Suite C-102

Oak Ridge, TN

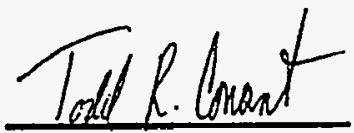

Evaluator's Signature

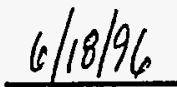

Date 

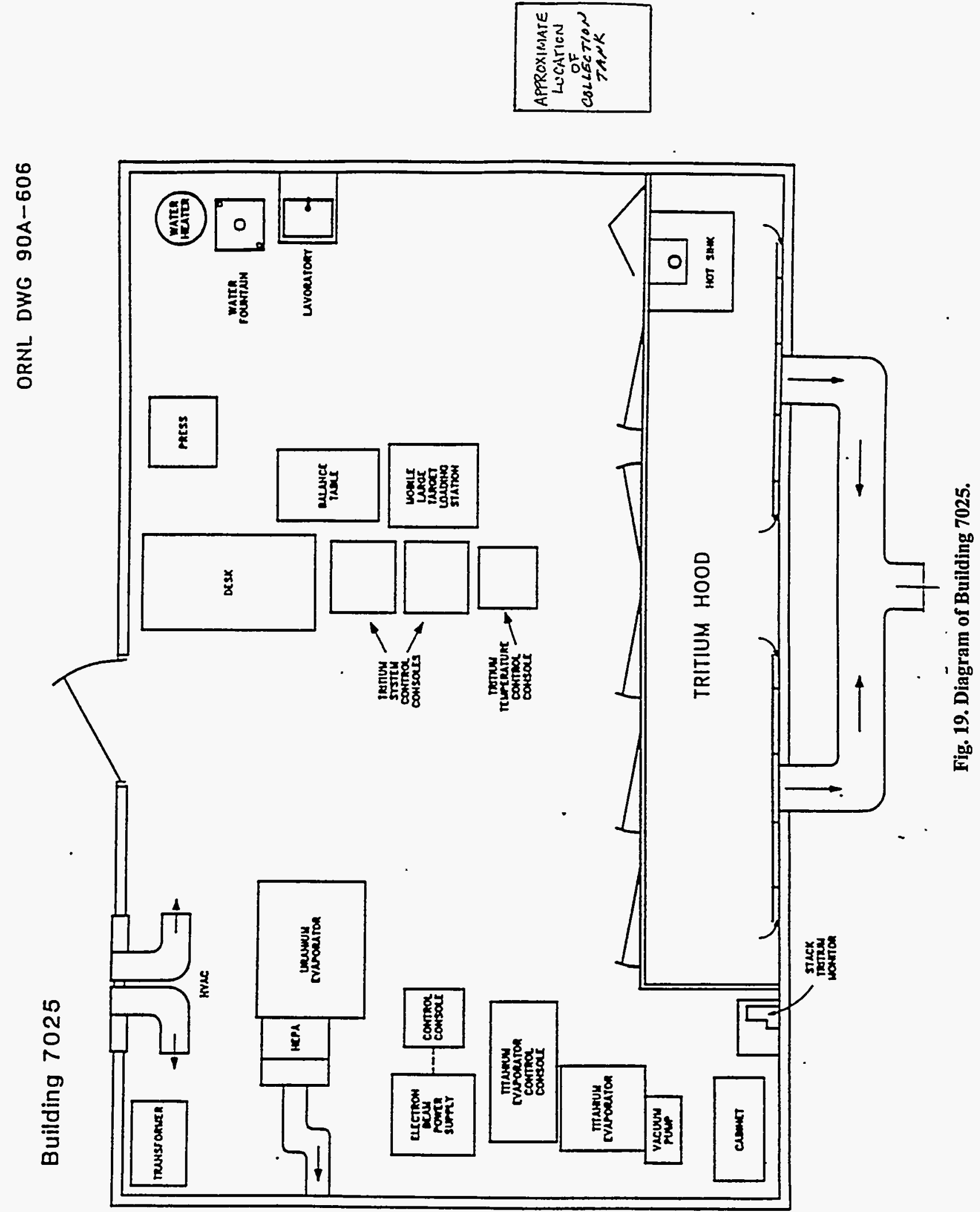

Arz 


\section{DISTRIBUTION}

1. L. V. Asplund

2. T. W. Burwinkle

3. K. W. Cook

4. R. E. Eversole

5. L. L. Kaiser

6-8. D. M. Matteo (3)

9. P. T. Owen

10. L. D. Owens

11. P. A. Schrandt

12. Central Research Library

13. ER Central Doc. Mgmt. Center-RC

14. R. L. Nace, Team Leader, Fernald/Ohio Team, Office of Environmental Restoration, U.S. Department of Energy, Cloverleaf Building, EM-425, 19901 Germantown Road, Germantown, MD 20874

15. J. W. Wagoner II, Team Leader, Portsmouth/Paducah/Weldon Spring Team, Office of Environmental Restoration, U.S. Department of Energy, Cloverleaf Building, EM-424, 19901 Germantown Road, Germantown, MD 20874

16. V. F. Boston, DOE Oak Ridge Operations Office, P.O. Box 2001, Oak Ridge, TN 37831-8541

17-18. R. C. Sleeman, Director, Environmental Restoration Division, DOE Oak Ridge Operations Office, P.O. Box 2001, Oak Ridge, TN 37831-8541 (2)

19-20. Office of Scientific and Technical Information, P.O. Box 62, Oak Ridge, TN 37831 (2)

21. T. R. Conant, Advanced Sciences, Inc., 800 Oak Ridge Turnpike, Suite C-102, Oak Ridge, TN 37830-6927 